Portland State University

PDXScholar

Spring 6-6-2017

\title{
Examination of Human Impacts on the Biodiversity and Ecology of Lichen and Moss Communities
}

Hannah Marie Prather

Portland State University

Follow this and additional works at: https://pdxscholar.library.pdx.edu/open_access_etds

Part of the Biology Commons, and the Forest Sciences Commons Let us know how access to this document benefits you.

\section{Recommended Citation}

Prather, Hannah Marie, "Examination of Human Impacts on the Biodiversity and Ecology of Lichen and Moss Communities" (2017). Dissertations and Theses. Paper 3615.

https://doi.org/10.15760/etd.5507

This Dissertation is brought to you for free and open access. It has been accepted for inclusion in Dissertations and Theses by an authorized administrator of PDXScholar. Please contact us if we can make this document more accessible: pdxscholar@pdx.edu. 
Examination of Human Impacts on the Biodiversity and Ecology of Lichen and Moss Communities

by

Hannah Marie Prather

A dissertation submitted in partial fulfillment of the requirements for the degree of

Doctor of Philosophy

in

Biology

Dissertation Committee:

Todd Rosenstiel, Chair

Sarah Eppley

Nancy Broshot

Linda George

Yangdong Pan

Portland State University

2017 
(C) 2017 Hannah Marie Prather 


\begin{abstract}
Globally, more than half of the world's population is now living in urban areas and it is well accepted that human activities (e.g. climate warming, pollution, landscape homogenization) pose a multitude of threats to ecosystems. Largely, human-related impacts on biodiversity will hold consequences for larger ecological processes, and research looking into human impacts on sensitive epiphytic lichen and moss communities is an emerging area of research. While seemingly small, lichen and moss communities exist on nearly every terrestrial ecosystem on Earth and contribute largely to wholesystem processes (e.g. hydrology, mineral cycling, food web energetics) worldwide. To further examine human impacts on epiphytic communities, I conducted three studies examining urbanization and climate warming effects on epiphytic lichen and moss biodiversity and ecology.

The first study I revisited a historic urban lichen community study to assess how urban lichen communities have responded to regional air quality changes occurring over the last nearly two decades. I further investigated, for the first time, the biodiversity of urban tree canopy-dwelling lichen communities in a native coniferous tree species, Pseudotsuga menziesii, at sites within the larger urban study. I found that urban parks and forested areas harbor a species rich community of lichens epiphytes. Further, I found evidence for the distinct homogenization of urban epiphytic lichen communities, suggesting that expanding beyond simplistic measures of biodiversity to consider community composition and functional biodiversity may be necessary when assessing the ecology and potential ecosystem services of epiphyte communites within urbanizing landscapes.
\end{abstract}


Next, I present the first tall tree canopy study across a regional gradient of urbanization near Portland, Oregon, USA. I found that tall tree canopy epiphyte communities change dramatically along gradients of increasing urbanization, most notably by the transitioning of species functional groups from sensitive, oligotrophic species to a dominance of urban-tolerant, eutrophic species, tracking with published results from regional ground-based studies. The implications these dramatic shifts in species composition have on essential PNW ecosystem processes, like N-fixation and canopy microclimate regulation, is still not well understood and difficult to conduct ecosystem-scale projects to formally evaluate. However, we find strong evidence that native conifer trees in urban areas may provide a diversity of essential ecosystem services, including providing stratified habitat for epiphyte communities and their associated microarthropod communities and the scavenging of excess atmospherically deposited nutrients. Future work is needed to understand how losses in canopy $\mathrm{N}$ fixation and species with large biomass (both lichens and bryophytes) will affect nutrient and hydrologic cycling in the PNW region, which continue to undergo rapid growth and urbanization.

The final chapter investigates the impacts of passive warming by Open Top Chambers (OTCs) in moss-dominated ecosystems located on the Western Antarctic Peninsula, an area of increasing climate warming. I compared species-specific temperature effects, moss canopy morphology, sexual reproductive effort and invertebrate communities between OTC and control moss communities for two moss species, Polytrichastrum alpinum and Sanionia uncinata, that make up over $65 \%$ of the terrestrial vegetative cover in the area. I found distinct reproductive shifts in $P$. alpinum 
under passive warming compared to controls. Moss communities under warming also had substantially larger total invertebrate communities than those in control moss communities, and invertebrate communities were significantly affected by moss species and moss reproductive effort. Further, substantial species-specific thermal differences among contiguous patches of these dominant moss species were revealed. These results suggest that continued warming will differentially impact the reproductive output of Antarctic moss species and is likely to dramatically alter terrestrial ecosystems dynamics from the bottom up.

This combined work provides a diverse contribution to the field of epiphyte ecology and biology by providing new insights on how human impacts will affect epiphyte lichen and moss communities across diverse ecosystems, in light of a rapidly changing planet. 
When we try to pick out anything by itself, we find it hitched to everything else in the Universe

John Muir, My First Summer in the Sierra (1911) 


\section{Acknowledgements}

I have been very fortunate to have the expertise and encouragement of many people on this work - this final result feels as much a reflection of their imprint as it is of my own efforts. I can't thank my parents enough for each of their unique influences on my life and constant encouragement through this process. Thanks to my father for truly gifting me a love of the natural world, your excitement and special ability to give pause to the sheer mystery and beauty of nature, instilled in me many of the same curiosities and wonderment. To my mother, for teaching me to be tenacious and brave, these skills have been well utilized. Your combined optimism and belief in me to do great things, despite the many years, gave me the courage to continue this path - thank you both.

I especially thank my advisor Todd Rosenstiel for his overall enthusiasm, guidance, and vision for this work. You believed in my success, long before I did, and I very much appreciate your confidence and support in me during this dissertation. I also thank Sarah Eppley for her continued generosity, advising and encouragement. Nancy Broshot, who always prioritizes her students and has encouraged me through all phases of this work. Linda George for serving on my committee and providing valuable insights that have greatly added to this work. Yangdong Pan for his generosity of time and statistical advising.

I thank both my advisors, T. Rosenstiel and S. Eppley, for including me on two Antarctic field seasons, this experience helped me develop a diversity of skills as a researcher and also offered great adventures that I will never forget. Thanks also to Angelica Casanova-Katny for her enthusiasm and expertise, and for being my Antarctic friend and roommate. These experiences have greatly imprinted my life. 
I am appreciative to the Portland State Biology Department for continued TA support through my dissertation work. Additionally, I am grateful to have been funded as a Cascades to Coast GK-12 fellow and for the unique experience and opportunity to teach and travel internationally with this group at the STRI facilities in Panama.

I am grateful for my experiences with the USFS, Region 6, Air Resources Monitoring Program, and particularly Linda Geiser, Doug Glavich, and Amanda Hardman, who provided me many graduate school "mini-vacations" to collect lichens in a number of beautiful wilderness and NF forest areas, I have many fond memories from these trips. Thanks to Larry St. Clair, Emily Holt, and particularly Sharon Siem with USFS Region 4, Wilderness/Wild \& Scenic Rivers Program for valuable experience and generous funding support to conduct lichen wilderness studies throughout the state of Utah.

A huge thanks to all the Rosenstiel-Eppley labmates, of past and present, and my GK-12 cohort who offered invaluable support and friendship through all the combined trials and successes of graduate school. Particular thanks to Erin Shortlidge, Mehmet Balkan, Timea Delkova, Matthew Chmielewski, Jason Maxfield, Andrea Melnychenko, Caitlin Maraist, Gina Marchini, Sarah Kidd, Nicole Alfafara, Monica Mogilewsky, Meghan Martin, Matthew Duveneck, Laura Holloway, Scott Kiel, Jennifer Groody, Andrew Clements, Jessica Shamek, Cecily Douglas, Sara Herrejon-Chavez, Erin Leal, Kristin Fratella and Kirsten Wright.

Thanks to an amazing group of "Lichen Ladies" who inspired me early in graduate school - Linda Geiser, Daphne Stone, Sarah Jovan and Amanda Hardman - you all have been exceptionally kind and encouraging to me and for that I am very grateful. I 
have been particularly inspired by all of you - your passion for lichens, your kind nature, and your fierce field skills.

Thanks also to Kendra Petersen-Morgan for her enthusiasm for this work and advocating for the urban tree climbing study. John Christy for expertise and enthusiasm for canopy bryophytes and his generous volunteer of time to identify bryophyte collections. Daphne Stone and John Villella for fostering an early love for lichens in my career and teaching me about identification. Michael Amacher for his expertise of lichen tissue analysis, data analysis, and quality control for my lichen tissue data. Bruce McCune for overall help with lichen identification, expertise and for loaning me his crossbow for tree access.

A special thanks to my climbing partner and friend, Tyler Zuniga, for generous donation of his time, gear and immense knowledge, I could not have accomplished such work in big trees canopies without you by my side. Thanks to my friends and PNW arborist community for further volunteer of time and expertise, particularly Seth Bailey, Orion Coleman, Isaac Brocker, John Brown, Louis Dixon, and Joe Mendenz who have all helped with tree access, data collection and overall good times being in trees - I am fortunate to know such an exceptional and talented group of humans.

To my siblings Rachel, Matt, Noah, Scott, and Trevor, each of you are appreciated and loved and surely this work would not exist without each and every one of you and your encouragement and influence on my life. To many dear friends and family, too many to list here, each of you are uniquely appreciated in my life and have contributed more to this final outcome then you probably know. And to Thomas, none of this would be possible without your unending support and confidence in me. Thanks for 
your willingness to patiently listen to me many, many times over and for always encouraging me in my endeavors. Lastly, to my sweet dog, Miss Apple, who didn't prove to be that field-worthy, but whose companionship and zest for life made many long days of writing and data analysis at home tolerable. 


\section{Table of Contents}

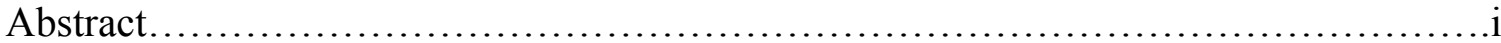

Dedication.....................................................................

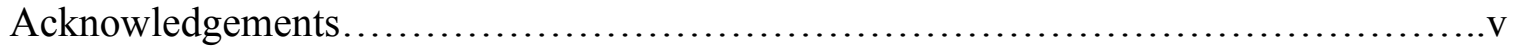

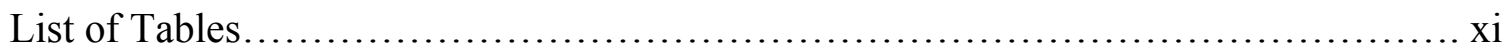

List of Figures...........................................................

\section{Chapter 1}

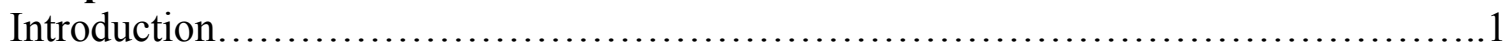

\section{Chapter 2}

Urban Forested Parks and Tall Tree Canopies Contribute to Lichen Epiphyte Biodiversity in Urbanizing Landscapes...................................................... 6

\section{Chapter 3}

Implications of Increasing Urbanization on Canopy-Dwelling Epiphyte Communities in

Tall Pseudotsuga menziesii in the Pacific Northwest, USA ............................ 35

\section{Chapter 4}

Species-Specific Effects of Passive Warming in an Antarctic Moss System on King George Island, Antarctica................................................. 75

\section{Chapter 5}

Conclusion................................................................. 112

References.................................................................. 117

\section{Appendix A}

Appendices List of Tables and Figures.....................................128

\section{Appendix B}

Supplemental Materials to Chapter 3: Implications of Increasing Urbanization on Canopy-Dwelling Epiphyte Communities in Tall Pseudotsuga menziesii in the Pacific Northwest, USA ................................................................129

\section{Appendix C}

Implications for Canopy Nitrogen Fixation in dominant cyanolichen Lobaria pulmonaria Across a Gradient of Urbanization in the Pacific Northwest, USA ...................136 


\section{Appendix D}

Measurements of intra-canopy NOx concentrations in tall Pseudotsuga menziesii.....142

Appendix E

Cascades to Coast GK12 Curriculum: Exploring Spatial Patterns of Lichens and Air

Quality in the Pacific Northwest....................................................... 143

\section{Appendix F}

Baseline Lichen Biomonitoring in USFS Region 4 Wilderness

Areas.................................................................... 153 


\section{List of Tables}

Table 2.1 List of historic urban park lichen surveys summarized by land classification

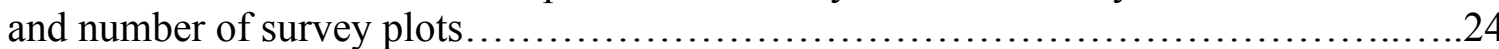

Table 2.2 Lichen species list for historic (1995-96, 2007) and current (2012-13) groundbased surveys categorized by species functional N-rating

Table 2.3 Lichen species list for urban park ground- and canopy-based surveys categorized by park location and species functional N-rating.

Table 3.1 Lichen species list for ground- and canopy-based surveys across regional urbanization site gradient. ...

Table 3.2 Bryophyte species list for canopy-based surveys across regional urbanization site gradient.

Table 3.3 Summary statistics of lichen tissue accumulated metals in ground-based collections of Platismatia glauca across a regional urbanization gradient.

Table 3.4 Summary statistics of lichen tissue accumulated metals in stratified canopybased collections of Platismatia glauca across a regional urbanization gradient.

Table 3.5 Summary statistics and ANOVA results of lichen tissue accumulated metals in ground-based collections of Platismatia glauca across a regional urbanization gradient. .68

Table 4.1 Cryptogam and plant species list by warmed (OTC) and un-warmed (control) plots on King George Island, Antarctica.

Table 4.2 Summary statistics of sex expression in $P$. alpinum cores sampled from warmed (OTC) and un-warmed (control) plots on King George Island, Antarctica 101 


\section{List of Figures}

Figure 2.1 Ordination plot from nonmetric multidimensional scaling (NMDS) showing significant changes in lichen community assemblages between historic and current site

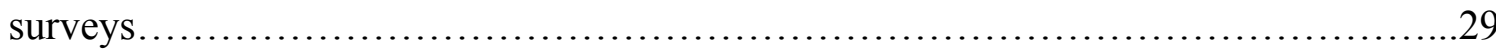

Figure 2.2 Bar graph showing metrics of species richness and biodiversity between historic and current urban park lichen community surveys........................................ 30

Figure 2.3 Bar graph showing ANOVA results by survey year for lichen species functional N-ratings.

Figure 2.4 Bar graph showing ANOVA results by survey year for lichen community derived air quality scores (AQ scores) and urban park location.

Figure 2.5 Bar graph displaying ANOVA results by canopy stratification for species functional N-ratings

Figure 2.6 Bar graph depicting ANOVA results by survey year and canopy stratification for lichen species ecological classification groups

Figure 3.1 Bar graph showing ANOVA results of lichen species richness and biodiversity by canopy stratification across regional urbanization site gradient

Figure 3.2 Bar graph depicting relative frequency of lichen species across regional urbanization site gradient by canopy stratification and species functional N-rating.......70

Figure 3.3 Bar graph showing ANOVA results by site location for lichen community derived air quality scores (AQ scores) and canopy stratification..................... 71

Figure 3.4 Bar graph depicting ANOVA results by site location for canopy stratification of $\% \mathrm{~N}$ and $\% \mathrm{~S}$ in $P$. glauca and $P$. sulcata lichen tissues...

Figure 3.5 Scatter plot displaying pooled $P$. glauca and $P$. sulcata tissue C:N ratio across regional urbanization site gradient.

Figure 3.6 Bar plot showing number and relative frequency of canopy dwelling microarthropods by site location.

Figure 4.1 Line graph showing moss canopy ( $P$. alpinum \& $S$. uncinata) temperatures in warmed (OTC) and un-warmed (control) plots in Antarctica...

Figure 4.2 Box-plots showing mean soil temperature and mean volumetric water content below moss patches in warmed (OTC) and un-warmed plots in Antarctica... 
Figure 4.3 Ordination plot from nonmetric multidimensional scaling (NMDS) showing no significant changes in cryptogam community assemblages after eight-years of experimental passive warming in Antarctica 104

Figure 4.4 Bar graph depicting ANOVA results for bryophyte and plant percent cover for OTC and control plots. 105

Figure 4.5 Bar graphs showing three moss canopy morphometrics for $P$. alpinum and $S$. uncinata in OTC and control plots.

Figure 4.6 Bar graph displaying ANOVA results for number of $P$. alpinum gametophytes placed into ontological categories for OTC and control plots.

Figure 4.7 Bar graph showing ANOVA results for proportion of $P$. alpinum ontological categories by OTC and control plots 108

Figure 4.8 Bar graph depicting ANOVA results for $P$. alpinum sex expression for OTC and control plots on King George Island, Antarctica.

Figure 4.9 Bar graphs showing ANOVA results of number of individual microarthropods and relative frequency of invertebrates extracted from mosses by OTC and control plots in Antarctica.................................................................. 110

Figure 4.10 Bar graphs depicting ANOVA results of number of individual microarthropods and invertebrates extracted by moss species for OTC and control plots in Antarctica. 


\section{Chapter 1}

\section{Introduction}

Human activities pose direct threats to ecosystems across the globe, yet the full extent of their impact on ecosystem properties (i.e. nutrient cycles, productivity, climate, hydrology, biogeochemical cycles) are still largely uncertain (Western 2001). More than half of the world's population are now living in urban areas (United Nations Department of Economic \& Social Affairs Population Division 2014), presenting a higher urgency to understand the consequences of human activities on species biodiversity and essential ecosystem processes. Loss of biodiversity as a result of human modification of ecosystems is a major concern in the current global environment (Vitousek et al. 1997, Chapin et al. 2000, Hillebrand and Matthiessen 2009, Pereira et al. 2010), and while often overlooked, non-vascular epiphytes (i.e. lichens and mosses) contribute significantly to global biodiversity and are abundant in diverse biomes worldwide, from extremely cold to extremely warm and from very dry to very wet ecosystems (Knops et al. 1991, Cornelissen et al. 2007, Ellis 2012). Exceptional diversity is coupled with important contributions to ecosystem function in many ecosystems, and globally lichens and mosses contribute significantly to ecosystem nutrient and hydrologic cycles (Pike 1978, Knops et al. 1991, Antoine 2004a, Pypker et al. 2006, Lindo and Whiteley 2011, Elbert et al. 2012, Ellis 2012, Porada et al. 2013, 2014, Stanton et al. 2014). Therefore, altered epiphyte biodiversity and the associated ecosystem processes could have enormous implications on habitat, hydrologic fluxes, and nutrient dynamics of remote ecosystems across the globe. 
Because of their existence in the interface of vegetation and the atmosphere, nonvascular epiphytes are particularly vulnerable to climatic changes and deposition of urban pollutants (Ozanne et al. 2003, Zotz and Bader 2009, He et al. 2016). Lichen and bryophyte communities rely exclusively on atmospheric moisture and nutrients, making them physiologically sensitive and responsive to urban pollutants across large regional gradients (Geiser and Neitlich 2007, Davies et al. 2007), and measures of their biodiversity (presence, absence, and abundance) have been used worldwide as an early sign bioindicator of ecosystem 'harm' (Berg et al. 1995, McCune 2000, Geiser and Neitlich 2007, Davies et al. 2007, Harmens et al. 2008, Perlmutter 2010). Human activities have historically had an effect on lichen and bryophyte communities, most notably significant events of biodiversity loss due to the effects of the industrial revolution, consequently epiphyte communities are among the most threatened and sensitive of ecological guilds at risk of human-related impacts (Goward and Arsenault 2000, Ozanne et al. 2003, Ellis et al. 2011, Ellis 2012).

Understanding how epiphytes respond to climate changes is also a challenge for biodiversity conservation and ecosystem planning (He et al. 2016). While their poikilohydric nature allows lichens and bryophytes to occupy some of the most extreme environments worldwide, their communities are particularly vulnerable to climatic changes due to the significant physiological pressures of warming temperatures (Zotz and Bader 2009, He et al. 2016). Increasing global temperatures are predicted to significantly affect biodiversity of lichens and bryophytes, which ultimately has consequence on ecosystem structure and function, nutrient and hydrologic cycling, and carbon balance (Elbert et al. 2012, Porada et al. 2014, He et al. 2016). Therefore, creating ecological 
linkages between ecosystem components, such as biodiversity and species functional roles as they relate to important ecosystem processes is imperative when considering collective human impacts on remote and 'pristine' ecosystems (Western 2001).

This thesis work is comprised of integrated approaches, spanning both urban and remote ecosystems, to investigate the effects of human impacts on epiphyte communities (specifically lichens and bryophytes) and present evaluation on ecosystem level outcomes. This dissertation provides a diverse study of epiphyte communities within two remote and 'pristine' global ecosystems, ranging from the isolated landscape of Antarctica to the treetop canopies of temperate Pacific Northwest forests. I present, for the first time, novel findings from the first study assessing the impacts of urbanization on tall, urban tree canopy epiphyte communities and further carry out the study to examine how tree canopy epiphyte communities respond to urbanization across a larger regional gradient in the Pacific Northwest. Lastly, I explore the effects of simulated climate warming on bryophyte communities in maritime Antarctica.

- In Chapter 2 I examine a historic survey of macrolichen epiphyte communities in the urban environment of Portland, Oregon, USA and, for the first time, assess biodiversity and ecosystem linkages in tall, urban canopy epiphytes communities.

- In Chapter 3 I investigate tall tree canopy epiphyte communities (lichens and mosses) across a larger regional urbanization gradient, to better understand how urbanization may induce community shifts and affect both biodiversity and resiliency of Pacific Northwest tree canopy ecosystems. 
- In Chapter 4 I examine species-specific responses of Antarctic bryophyte communities under conditions of simulated climate warming on King George Island, Antarctica.

- In Chapter 5 I provide a conclusion of the work presented.

Despite their wide-spread ecological importance, the effects of global change on bryophyte and lichen biodiversity and associated ecosystem function has received remarkably little attention. In this thesis, I present results from my $\mathrm{PhD}$ research aimed at understanding the complex effects of human impacts (both urbanization and climate warming) on some of Earths most sensitive, ancient, and poorly understood communities - the mosses and lichens. I examine these questions in two ecosystems dominated by these communities, the arboreal epiphytic canopy of the Pacific Northwest and the icefree terrestrial regions of the Western Antarctic Peninsula. My dissertation work adds a novel approach of vertical, tall tree assessment of epiphytic canopy communities across a gradient of increasing urbanization and a diverse experimental approach to examine how bryophyte communities may respond to rapidly climate warming along the Western Antarctic Peninsula. In Chapters 2-4, as outlined above, I discuss my work completed towards this dissertation; Chapter 5 I provide a conclusion on the broader implications of this work and further directions for research; Appendix A I provide supplemental materials pertaining to Chapter 3; Appendix B I assess rates of $\mathrm{N}$-fixation in Lobaria pulmonaria along a gradient of increasing urbanization in the Pacific Northwest; Appendix C I show results of intra-canopy measurements of $\mathrm{NO}_{\mathrm{x}}$ (nitrogen oxides) concentrations made across a six-month sampling period in a 60m tall urban Pseudotsuga menziesii tree; Appendix D I include school curriculum for engaging high school 
students in regional lichen biomonitoring investigations with database inquires and data analysis; lastly, Appendix E includes a summary of baseline epiphytic lichen surveys performed for the USFS Region 4, Wilderness/Wild \& Scenic Rivers Program across seven different wilderness areas of Utah, USA. 


\title{
Chapter 2
}

\section{Urban Forested Parks and Tall Tree Canopies Contribute to Lichen Epiphyte Biodiversity in Urbanizing Landscapes}

\begin{abstract}
The Pacific Northwest region is one of the most rapidly growing areas of the United States, with population increases estimated to grow more than fifty percent by 2050 . Continued land modification through urbanization can dramatically impact species specific survival as well as alter patterns of regional biodiversity, leading to complex, ecosystem scale, interactions that may yield both positive and negative impacts on urban and ex-urban biota. Despite rapid population growth in the Pacific Northwest, relatively little is known about how human activities affect urban tree biology and more specifically how urbanization impacts tall tree canopy epiphyte communities, a unique and sensitive component of Pacific Northwest trees, known to contribute a number of essential ecosystem functions. Here, we revisit a historic urban lichen community study, initially conducted 18 years ago by the USFS ARM (Air Resources and Management) Program in Portland, Oregon, USA. The goal of this work was to assess how urban lichen communities have responded to the improvements in regional air quality occurring over the last nearly two decades. We further comprehensively investigated the biodiversity of urban arboreal lichen communities in a native coniferous tree species, Pseudotsuga menziesii, nested at sites within the larger urban study. Our results show, for the first time, that tall, urban conifer trees and urban parks and forested areas can provide both heterogeneous and stratified habitats for a number of urban-tolerant epiphytic lichens. However, we further revealed significant and highly eutrophied lichen communities in all
\end{abstract}


epiphytic surveys, suggesting that continued growth in transportation throughout the Portland metro region might continue to impact these communities despite overall gains in regional air quality during the 18-year study period. Our results give evidence for the distinct homogenization of urban epiphytic lichen communities, suggesting that expanding beyond simplistic measures of biodiversity to consider community composition and functional biodiversity may be necessary when assesesing the ecology and potential ecosystem services of epiphyte communites within urbanizing landscapes. We discuss how urban biotic homogenization may affect tall, urban conifer canopies, their associated ecological processes, and the potential impacts of continued urbanization on Pacific Northwest forest ecosystems.

\section{Introduction}

The process of urbanization, transitioning landscapes from predominately rural to predominately urban, is a major threat to global biodiversity (Vitousek et al. 1997, Chapin et al. 2000, Hillebrand and Matthiessen 2009, Pereira et al. 2010), altering ecosystem processes and the resiliency of ecosystems to environmental change (Naeem et al. 1999, Chapin et al. 2000). The expansion of urban areas is on average twice as fast as urban population growth, this unprecedented speed and scale of urban land cover in the $21^{\text {st }}$ century will result in significantly greater urbanization than the cumulative urban expansion in all of human history to date (IPCC 2014).

The effects of urbanization on biodiversity have generated mixed results, indicating both positive and negative impacts for biota. Traditionally, urban environments have been thought to hold negative effects for biotic communities (Seto et al. 2012), as 
urbanization can result in reduced biodiversity from habitat loss, physiological stress (i.e. air pollution, urban heat island effect), fragmentation, and disturbance. More recent work however, has shown the potential of urban environments to contribute to biodiversity, specifically habitat heterogeneity and green infrastructure in the urban environment can foster plant biodiversity and harbor sensitive/rare plant species (Kowarik 2011, Guénard et al. 2014, Nielsen et al. 2014, Pinho et al. 2016). Parks and urban forested areas, in particular, have been shown to significantly increase the biodiversity of multiple groups of species in urban landscapes (i.e. birds, lichens, etc.) (Nielsen et al. 2014, Pinho et al. 2016).

In the Pacific Northwest (PNW) region of the United States, forest ecosystems are important terrestrial settings for a suite of ecological processes (nutrient and carbon cycling, regulation of hydrologic cycles, wildlife habitat, etc.). Tree canopy dwelling macrolichen epiphytes in the PNW make up a large biodiversity (+/- 45 species, Jovan 2008) and biomass ( 2.6 t/ha, McCune 1993) in arboreal (tree canopy) habitats. Lichens can be inconspicuous and are often easily underestimated for ecosystem level contributions, yet epiphytic lichens have been shown to be fundamental to many ecological processes (nutrient cycling, regulation of microclimate, wildlife habitat, nesting material, etc.) in forest ecosystems (Coxson and Nadkarni 1995, Pettersson et al. 1995, McCune 2000, Antoine 2004b, Wolf 2009). Urban trees, and the larger urban forest they comprise, contribute similar ecological processes as that of natural forest ecosystems, influencing microclimate, improving air quality, regulating hydrologic cycles and harboring wildlife (Ordóñez and Duinker 2012, Rao et al. 2014), and have well recognized as important ecological infrastructure of urban cities. While the benefit 
of urban trees has been well established, urban lichen epiphytes are often overlooked for their importance and role in the ecology of urban landscapes.

Lichen epiphytes are particularly sensitive and responsive to changes in air quality and climatic variables (Geiser and Neitlich 2007, Jovan 2008, Geiser et al. 2010, Root et al. 2015). Elevated $\mathrm{N}$ and heavy metal deposition can stimulate dramatic shifts in lichen community structure, thus making community-level response useful as an earlysign indicator of ecosystem degradation (Geiser and Neitlich 2007, Davies et al. 2007). Lichen community shifts often result in replacement of sensitive, endemic species by $\mathrm{N}$ tolerant, weedy eutrophic species (Jovan and McCune 2005, Jovan et al. 2012). The dramatic shift in lichen communities near urban environments, often used as an early indication of ecosystem harm, can be expected to further result in shifts in functional biodiversity and ecological contributions of canopy dwelling lichen epiphytes.

Particularly concerning in the PNW, is the paucity of sensitive cyanolichens near urban areas, such as the large, leafy Lobaria pulmonaria and Lobaria oregana, which are important components of overall epiphytic biomass in tree canopies and an vital source of new N in PNW coniferous forests (Pike 1978, Antoine 2004b). Additionally, urbanization and increasing $\mathrm{N}$ deposition can lead to stunted and bleached thalli of multiple species (>4.0 $\mathrm{kg} \mathrm{N} \mathrm{ha}^{-1} \mathrm{yr}^{-1}$, Grenon 2012), holding ecological impacts for lichen species that are used for forage, nesting, and habitat by birds and arthropods.

Both lichens and bryophytes are thought to be facing great changes in regard to their abundance, biomass and composition as consequence of global environmental changes (Cornelissen et al. 2007), however, urban tree canopy-dwelling epiphytes may lie in the zone of greatest impact from plumes of urban air. I therefore aimed to evaluate 
the functional and ecological role of canopy-dwelling lichens in urban environments. We predicted that shifts in lichen community composition, as a result of urban air exposure, might be more evident than those observed in only ground-based studies. We further hypothesized that tall $(55 \mathrm{~m}-60 \mathrm{~m})$ urban tree canopies could also contribute positively to urban lichen biodiversity, by providing a large, stratified habitat in urban environments. Additionally, we anticipated that tall urban tree habitats may potentially harbor sensitive lichen species that would otherwise be undetected in ground level surveys.

We used an existing, historical survey of lichen and air quality plots by the USFS Air Resource Management Program (ARM) to serve as a setting for the first field based approach to validate vertical urban canopy lichen biodiversity in the rapidly urbanizing area of Portland, Oregon, USA. The historic survey also allowed assessment of past and present day air quality, as derived from lichen community analyses, for the Portland Metro area. To understand how increasing urbanization in the PNW will affect canopy lichen communities and the resulting impacts on the functional and ecological impacts of an altered canopy community on native forests, we used the native conifer tree species, Douglas-fir (Pseudotsuga menziesii Mirb. Franco), to conduct layered vertical surveys of lichen biodiversity (species presence and abundance) with paired ground level surveys in three large, urban forested parks.

\section{Materials and Methods}

\section{Study area}

The study was carried out in the metropolitan area of Portland, Oregon, USA in eight urban and suburban parks. The Portland Metro area covers $330 \mathrm{~km}^{2}$, with parklands 
comprising just over $17 \%\left(57.48 \mathrm{~km}^{2}\right)$ of the metro city area ("ParkScore" 2016). Portland park landscapes are variable in amount of development, ranging from fully developed inner city park areas to more undisturbed, natural urban forest parks. This diversity of park landscapes creates a unique overstory canopy matrix of non-native tree cultivars as well as native tree species all within the urban landscape of the Portland Metro. The land classification for the parks selected in this study includes urban, suburban, semi-natural, and natural forested park areas. Most notably in the study is Portland's Forest Park, the largest urban forest park in the United States, encompassing 2,064ha along the northwest section of downtown. The overstory canopy of Forest Park is comprised of native conifer species such as Douglas-fir (Pseudotsuga menziesii), western hemlock (Tsuga heterophylla), and western redcedar (Thuja plicata) and native hardwoods bigleaf maple (Acer macrophyllum) and red alder (Alnus rubra). Five of the parks selected in this study (Forest Park, Mt. Tabor, Oxbow Regional Park, Tryon Creek State Natural Area, and Washington Park Zoo) have Douglas-fir (Pseudotsuga menziesii), a native conifer species, as the primary overstory species.

\section{Historic lichen community data}

In 1995-96 \& 2007 the USDA Forest Service Air Resources Management (ARM) Program surveyed ground-level epiphytic macrolichen biodiversity at thirteen urban plots, located in eight Portland, Oregon area parks (Table 2.1). This historic study was part of a larger regional sampling effort to understand gradients in epiphytic lichen community response to regional air pollution and climatic gradients, with particular interest on regional gradients of $\mathrm{N}$ deposition away from the large, urban metropolitan 
areas Seattle, WA and Portland, OR extending east towards the Cascade Mountain Range (Geiser and Neitlich 2007). Trained field technicians collected voucher specimens and estimated the visual abundance of each epiphytic macrolichen detected in circular 0.38ha plots, following the FIA lichen community protocol (USDA-Forest Service 2004). The ground level sampling method designates the collection of lichen epiphytes that occur on woody substrates, above $0.5 \mathrm{~m}$ from ground level, and from recently fallen branches ad canopy throughfall within the plot area, thus it is designed to provide a 'capture' of the canopy dwelling lichen community. However, due to difficulties and limitations of climbing trees, not many paired canopy/ground surveys have been done to verify this methodology in the PNW. These historic lichen community data are housed on the USFS Lichen and Air Database (http://gis.nacse.org/lichenair/index.php), and the expansive network of regional sampling, which encompasses gradients of both air quality and environmental variables across 1416 forested plots, has resulted in a robust model where lichen community assemblages can be used to predict $\mathrm{N}$ deposition and climate environments across the PNW region (Geiser and Neitlich 2007, Geiser et al. 2010, Root et al. 2015).

We used the historic USFS established urban lichen plot survey array as a setting to examine urbanized lichen communities in the Portland, Oregon Metropolitan region, both at ground level and within a subset of urban tree canopies. We conducted matched lichen community surveys at the thirteen historic USFS plots in 2012-13 to provide a capture of current and historic air quality as indicated by epiphytic lichen communities in the Portland Metro area. We used replicate survey methods as the original lichen community surveys; original plot locations were relocated with precise GPS coordinates. 
Lichens were identified using McCune and Geiser (2009) from morphology, spot tests, and thin layer chromatography.

\section{Arboreal lichen community data}

We examined, for the first time, urbanization impacts on arboreal lichen biodiversity in an urban dwelling, native conifer tree species. We selected a subset of urban parks from the historic USFS plot array for vertical tree canopy surveys. Three urban forest parks, with varying amount of surrounding urbanization, were selected and one tall Douglas-fir (Pseudotsuga menziesii) tree was chosen for vertical survey and comparison to a paired ground based survey. The small sample size reflects the difficulty of locating inner-urban parks with mature, tall, conifer trees where we would expect to see an established or developing canopy epiphyte community. Portland is a unique metropolitan area in the PNW where tall, coniferous urban forest patches have been preserved within the metro park system and each park chosen was searched for mature trees that had topographic exposure (not located in creek beds or steep drainages) to the surrounding urban air plumes. Trees that were over $100 \mathrm{~cm}$ DBH (diameter at breast height) and tree heights ranging between 55-60m, with full, intact canopies safe for climbing access were chosen for arboreal lichen surveys.

Trees were rigged for climbing by propelling a weighted throwball attached to high-tensile strength throwline over suitable climbing limbs in the uppermost canopy. Climbing ropes were then pulled through to allow vertical ascent into the crown. Single rope climbing techniques (SRT) were used to access the crown and short canopy ropes were used for in-canopy movements. Tree height was measured to the top of the most 
apical portion of the crown; depth of crown was measured from the lowest live branch whorl to the most apical portion of the crown. The crown was divided into three canopy sections: top, mid, and lower crown. We used a modified FIA lichen community protocol survey (USDA-Forest Service 2004) to describe arboreal lichen communities at each of three canopy survey locations, in each study tree. Each canopy section was surveyed for a maximum of 1 hour, or until no new species had been recorded in a 10 min period. Epiphytic lichens were collected from all substrates (branches and bole) within the canopy survey location. Each unique lichen species was vouchered and an ocular abundance value was recorded (see USDA- Forest Service 2004).

\section{Statistical Analyses}

To reveal changes in lichen community assemblages between the historical and current ground based surveys, a species abundance matrix was ordinated using non-metric multidimensional scaling (NMDS) in R studio (Version 0.99.473 2009-2015 RStudio Team 2015) using package "Vegan" (Oksanen et al. 2011). Using Bray-Curtis distance measures, and square root data transformation, we chose a two-dimensional solution with the best stress (17.44) based on 20 runs of 1000 permutations. An analysis of similarity (ANOSIM) was used to statistically test for differences between past and present species assemblages.

Two-way ANOVA using Graph Pad Prism (Version 5.0 for Mac Graph Pad Prism 2007) was used to analyze the interactions between number of species, $\mathrm{N}$ functional groups, ecological classified groups and the year of survey and vertical stratification of survey (ground or canopy). Unpaired t-tests were used to determine the effect of vertical 
stratification (canopy vs. ground) on lichen AQ scores. Tukey's tests were used to determine significance among factors. Discrimination between $\mathrm{N}$ functional groups (eutroph or nitrophilous $\left(>4.6 \mathrm{~kg} \mathrm{~N} / \mathrm{ha}^{-1} / \mathrm{yr}^{-1}\right)$, mesotroph $\left(2.5-4.5 \mathrm{~kg} \mathrm{~N} / \mathrm{ha}^{-1} / \mathrm{yr}^{-1}\right)$, or oligotroph $\left(<2.4 \mathrm{~kg} \mathrm{~N} / \mathrm{ha}^{-1} / \mathrm{yr}^{-1}\right)$ followed McCune and Geiser (2003). Lichen ecological groups were modeled after classifications by McCune et al. (1997) and Sillett and Rambo (2000); eutroph (Candelaria sp. Physcia sp., Xanthoria sp.) green algal (Hypogymnia sp., Platismatia sp.), alectorioid (Alectoria sp., Bryoria sp., Usnea sp.), and cyanolichens (Lobaria sp.).

\section{Regional Lichen, Air Quality, \& Climate Gradient Model Analyses}

We used the Geiser \& Neitlich (2007) regional lichen, air quality and climate model to ordinate lichen community data from current park surveys and canopy surveys within the larger archive of regional sites (1,416, 0.4ha regional forested plots) and generated air scores for the historic, current, and canopy surveys with the parameters described in Geiser \& Neitlich (2007), using non-metric multidimensional scaling (NMS) in PC-ORD (McCune \& Mefford 1999). Positive air score values indicate polluted sites, while negative air score values indicate clean sites.

\section{Results}

\section{Lichen Community Data}

A significant change in urban lichen community assemblages (species presence and abundance) occurred between historic and current ground based FIA surveys (Figure 2.1, NMDS, Stress $=0.17$; ANOSIM test statistic $\mathrm{p}=0.005, n=13)$. We found 60 unique 
epiphytic macrolichen species in the 8 urban parks surveyed (Table 2.2), compared to 61 total species found in the historic surveys. Lichen species richness varied by park location; the highest species richness was found in Oxbow Regional Park [30] and the lowest was in Riverfront Park [11] (Figure 2.2a). These findings are fairly consistent with historic surveys; highest species richness [30] recorded at Oxbow Park, the lowest species richness [8] in both Riverfront Park and the Oregon Zoo. Species richness was lowest in parks that were nearer the downtown center [Riverfront Park] or abutted a major freeway corridor [Delta Park and Oregon Zoo] and had epiphytic communities comprised of primarily all eutrophic species. Species richness was highest in parks that were further from the downtown center and contained a unique assemblage of both eutrophic and oligotrophic species, which resulted in high measures of species richness. Species diversity, calculated using the Shannon-Wiener diversity index, increased at all but one park (Figure $2.2 b$ ). Overall, parks with historically high diversity remained the highest in current year surveys and parks with historically low diversity also remained lowest.

We found both historic and current park surveys revealed highly eutrophied lichen communities (Figure 2.3b). A high frequency of eutrophic, nitrophilous species, (greater than 35\% eutrophic species) within the total proportion of lichen community indicates ecosystem $\mathrm{N}$ inputs are high, ranging upwards of $3.5 \mathrm{~kg} / \mathrm{ha} / \mathrm{yr}$, in all urban parks surveyed (Figure 2.3b). The total proportion of eutrophic species in the ground based surveys ranged from $26 \%$ - $91 \%$ of total community composition; no significant changes were seen between historic and current surveys (Figure 2.3b, two-way ANOVA, $\mathrm{F}=0.001, \mathrm{p}=0.96, n=13)$, therefore, the historic and current lichen communities remain 
saturated with eutrophic, nitrophilous species. A significant increase in total number of eutrophic species occurred between historic and current ground based surveys (Figure 2.3a, two-way ANOVA, F=35.43, $\mathrm{p}=0.001, n=13)$.

\section{Regional Lichen, Air Quality, \& Climate Gradient Model}

Air scores are derived from lichen community gradients in the larger, regional NMS ordination model (Geiser and Neitlich 2007). High air scores indicate the most polluted sites; all air scores in this study indicate polluted sites (clean air sites return a negative air score value). The highest air scores occurred in parks with low species richness, a high proportion of eutrophic species, and were closest to the downtown urban center or a main freeway corridor (Figure 2.4). The lowest air scores were found at parks with high species richness, a wide range of lichen $\mathrm{N}$ functional groups, and furthest from the downtown center. No significant difference occurred between historic and current park air scores (Figure 2.4, two-way ANOVA, $\mathrm{F}=0.001, \mathrm{p}=0.99, n=13$ ). Air scores did not differ significantly between ground and canopy paired surveys (t-test, $\mathrm{p}=0.77, n=9$ ).

\section{Arboreal lichen community data}

We found a total of 29 lichen species in the urban arboreal surveys (Table 2.3). On average, 7 species were found only in canopy surveys and 8 species were found only in ground surveys and not in canopy surveys. Overall, the vertical canopy species surveys did accurately reflect paired ground level surveys; mean ground level species capture was $81 \%$ of canopy species and comparably, mean canopy species capture was $68 \%$ of ground level species records. No lichen species were found unique to only the canopy 
surveys, however each urban survey type (ground vs. canopy) has a limitation of $+/-7-8$ species, with ground level surveys often overestimating diversity of large overstory conifer tree canopies due to the larger sampling area ( $0.4 \mathrm{ha})$ and greater availability of microsites.

Canopy surveys revealed a high frequency of eutrophic species; the proportion of eutrophic species ranged from $42 \%-67 \%$ of total community composition, which was also reflected in the paired ground level plots; no significant differences occurred between ground and canopy level surveys (Figure 2.5, two-way ANOVA, F=0.00, $\mathrm{p}=0.99, n=9$ ). A significant increase in number of eutrophic lichen species (Figure 2.6a, $\mathrm{F}=51.46, \mathrm{p}=0.001, n=13$ ) and number of green algal species (Figure 2.6a, $\mathrm{F}=51.46$, $\mathrm{p}=0.001, n=13$ ) was found between historic and current surveys. When lichens were grouped by their ecological classification, we further showed low numbers of alectorioid species and a total absence of cyanolichen species (Figure 2.6b), in the paired urban conifer canopies and ground level plots. Lobaria pulmonaria and L. oregana were absent and not detected in any of the conifer canopies surveyed.

The canopy surveys also revealed an unexpected amount of visual tissue damage, bleached and necrotic lichen tissues were visible in both Platismatia glauca and Parmelia sulcata, in situ, otherwise not detectable in ground based surveys. Many canopy lichen species (Hypogymnia sp., Platismatia sp., Usnea sp.) showed visual signs of air pollution injury, as evidenced by stunted and compact thalli.

\section{Discussion}


The Pacific Northwest region is one of the most rapidly growing areas of the United States, with population increases estimated to grow more than fifty percent by 2050. Continued land modification through urbanization will result in species specific responses on plant biodiversity, yet the most significant ecological effects of shifting biodiversity will be how the functional role of species within an ecosystem are affected by urbanization (Clavel et al. 2011). In this study, we investigated arboreal lichen communities in a native urban-dwelling coniferous tree species, nested in a larger historic urban park lichen plot array in Portland, Oregon, USA. We found evidence that tall tree canopies and urban parks and forested areas can function as heterogeneous areas that contain a high biodiversity of urban-tolerant epiphytic lichens. However, while urban arboreal lichen communities do not show low biodiversity, they show evidence of biotic homogenization, where ecologically important, functional groups are replaced with widespread, urban-tolerant species.

\section{Effects of urbanization on lichen biodiversity}

We found that urban parks and forested areas provide a heterogeneous environment, leading to species rich community of lichen epiphytes. Using the historic FIA lichen survey plot array, we found a significant change in lichen community assemblage (presence/absence and abundance) occurred between historic and current ground-based surveys (Figure 2.1). We further found that urban plots gained new species and biodiversity of species (presence and abundance) also increased over time (Figure 2.2a/b). The frequency of pollution tolerant, N-loving species showed little change over the 18-year period, suggesting a saturation of eutrophic lichen species (Figure 2.3b), 
which resulted in no significant change in lichen community gradient derived air scores between historic and current surveys (Figure 2.4). Further, the recruitment of new species was primarily $\mathrm{N}$ loving, eutrophic species (Figure 2.3a). The increase of eutrophic species over time and a eutroph dominated lichen community may suggest that despite distinct improvements in regional air quality across the same time period, as implemented by the 1990 Clean Air Act Amendments, these air quality regulations may not be significant enough to show detectable improvements in sensitive lichen epiphyte communities. A highly eutrophic lichen community may also suggest that urban ecosystem $\mathrm{N}$ inputs may prohibit $\mathrm{N}$ sensitive oligotrophic species from establishing, or that a dominance of eutrophic species themselves may competitively limit the establishment of sensitive oligotrophic species. Either mechanism has resulted in an absence of sensitive, and functionally important, species from establishing in this urban park and arboreal environment.

\section{Effects of urbanization on canopy function and ecology}

Urban tree canopies in this study were highly eutrophied. While the urban canopies still contained a moderate number of species, we found that primarily all species detected were indicating high $\mathrm{N}$ environment and a low frequency of $\mathrm{N}$ sensitive species occurred. Urban canopies also lacked ecologically important groups of alectorioid lichens and a complete absence of arboreal cyanolichens (Figure 2.6b). We found that urban arboreal conifer canopies are more species poor than their paired ground level survey plots, suggesting that ground-based surveys may over-estimate species richness in urban affect plots with a dominant overstory of large conifer trees. This discrepancy may be due 
to a higher variation of microsites at ground level than in the large overstory canopy of a single conifer tree. Interestingly, many of the eutrophic species found in the arboreal study are those that would typically be preferentially to hardwood tree substrates and not occur on acidic substrate of conifer bark. This may suggest that $\mathrm{N}$ inputs are so high that eutrophic species are less specific to substrate $\mathrm{pH}$, or that substrate $\mathrm{pH}$ may be altered (buffered) by urban deposition.

The urban canopy surveys also revealed a surprising amount of bleached and necrotic lichen damage in situ, not otherwise observable in ground-based surveys. Platismatia glauca, Parmelia sulcata, and Usnea spp. were visibly stunted in the arboreal surveys, suggesting that presence or absence of species cannot determine ecological contribution as many lichen epiphytes also become physically altered in urban areas. Stunted thalli size of otherwise larger biomass species, as well as the overall compact thalli sizes of many eutrophic species (Candelaria sp. Physcia sp., Xanthoria sp.), may affect PNW canopy microclimate, as reduced biomass of epiphytes may lower canopy water retention. Additionally, tissue damage and stunted thalli may affect habitat quality of epiphytes for invertebrates within tree canopies.

These results suggest that urbanization can foster biodiversity, yet urbanization results in homogenization of the functional role of canopy epiphyte communities, as observed in other regional studies (Geiser and Neitlich 2007, Root et al. 2015). This is in contrast to some studies, where low species richness equated to biotic homogenization (Buczkowski and Richmond 2012, Deguines et al. 2016). The combined sensitivity of many functionally and ecologically important lichen species and the rapid spread of urbanization in the PNW region will have a significant result on Pacific Northwest forest 
ecosystem processes such as canopy $\mathrm{N}$ fixation, canopy microclimate regulation, and habitat and forage sources. The resulting impacts of a homogenized, urban-tolerant lichen community on tree canopy communities and ecosystem functioning have not been well discussed in either urban cities or in rapidly urbanizing areas along the urban peripheral, yet is a pressing issue in regards to global change (Clavel et al. 2011).

\section{Conclusion}

This study is the first in examining urbanization impacts on tree canopy lichen biodiversity and the resulting impacts of epiphyte community shifts on functional biodiversity of PNW tree canopies. Our results suggest that tall urban conifer trees can serve as important, stratified habitats for lichen epiphytes. Additionally, we found that urban parks and forested areas can harbor a species rich community of lichens epiphytes and that such biodiversity has been sustained over and 18-year time period in the urban area of Portland, OR. Measures of biodiversity are important indicators for environmental assessment, however a critical limitation of many biodiversity indices is that community composition and functional biodiversity are not always interpretable (Di Battista et al. 2016). Therefore, the pattern of biotic homogenization in the urban forest canopies we observed, where sensitive, endemic canopy species are replaced with widespread generalists (McKinney and Lockwood 1999, McKinney 2006, Concepción et al. 2015), may have profound implications on the function of both urban and natural forest canopies

,as well as larger forest ecosystem processes, given the persistent the global expansion of urbanizing regions. 


\section{Acknowledgements}

We would like to thank Portland Parks and Recreation, specifically Kendra PetersenMorgan, and Oregon State Parks for permitting the ground and arboreal studies. Special thanks to Tyler Zuniga for climbing expertise and generous volunteer of time on this project. Doug Glavich for help with lichen identification. O. Coleman, I. Broker, S.

Bailey, and J. Brown for additional climbing support and to Laura Holloway for assistance in the field. 
Table 2.1 Eight Portland, Oregon parks used in the study, summarized by land classification and the number of survey plots installed by the USDA Forest Service Air Resources and Management regional air quality and lichen study.

\begin{tabular}{ccc}
\hline $\begin{array}{c}\text { Year of Historic } \\
\text { Survey }\end{array}$ & Land Classification & $\begin{array}{c}\text { Number of } \\
\text { Survey Plots }\end{array}$ \\
\hline \hline 1995,1996 & $\begin{array}{c}\text { Urban Parks: } \\
\text { Delta Park (DP), Riverfront Park (RP), Oregon Zoo } \\
\text { (OZ) }\end{array}$ & 4 \\
1995,2007 & Urban Forested Parks: \\
& Forest Park (FP), Mt. Tabor Park (MtTP), Tryon \\
Creek State Natural Area (TCSNA) & 7 \\
\hline & Suburban Parks: \\
& Oxbow Regional Park (ORP), Sandy River Delta \\
(SRD) & 2 \\
\hline
\end{tabular}


Table 2.2 Lichen species list from historic (1995-96, 2007) and current year (2012-13) ground-based community surveys of eight Portland, Oregon, USA parks $(n=13)$.

Detections are the number of times a species was found in the 13 unique study plots and the corresponding year of survey. The $\mathrm{N}$ functional group $(\mathrm{E}=$ eutroph, $\mathrm{M}=$ mesotroph, $\mathrm{O}=$ oligotroph) for each species is shown in the leftmost column.

\begin{tabular}{|c|c|c|c|}
\hline & & Historic & Current \\
\hline N-Rating & Scientific Name & \multicolumn{2}{|c|}{ Number of Detections } \\
\hline $\mathrm{M}$ & Bryoria capillaris & 1 & \\
\hline $\mathrm{O}$ & Bryoria fuscescens & & 1 \\
\hline $\mathrm{E}$ & Candelaria concolor & 9 & 10 \\
\hline E & Cetrelia cetrarioides & 4 & \\
\hline $\mathrm{O}$ & Cladonia carneola & & 1 \\
\hline $\mathrm{E}$ & Cladonia fimbriata & & 1 \\
\hline $\mathrm{E}$ & Cladonia macilenta & 4 & \\
\hline M & C. ochrochlora, C. coniocraea & 1 & 2 \\
\hline $\mathrm{E}$ & Cladonia squamosa & 2 & 3 \\
\hline $\mathrm{O}$ & Cladonia transcendens & & 7 \\
\hline \multirow[t]{2}{*}{ M } & Cladonia umbricola & 1 & \\
\hline & Cladonia spp. & & 1 \\
\hline $\mathrm{E}$ & Collema nigrescens & 1 & \\
\hline $\mathrm{E}$ & Evernia prunastri & 13 & 13 \\
\hline $\mathrm{E}$ & Flavopunctelia soredica & & 2 \\
\hline $\mathrm{O}$ & Hypogymnia apinnata & 1 & 3 \\
\hline $\mathrm{O}$ & Hypogymnia enteromorpha & 3 & 4 \\
\hline $\mathrm{O}$ & Hypogymnia imshaugii & & 1 \\
\hline M & Hypogymnia inactiva & 4 & 8 \\
\hline $\mathrm{E}$ & Hypogymnia physodes & 10 & 12 \\
\hline M & Hypogymnia tubulosa & 9 & 13 \\
\hline $\mathrm{O}$ & Hypotrachyna revoluta & & 1 \\
\hline $\mathrm{O}$ & Hypotrachyna sinuosa & 1 & 2 \\
\hline M & Leptogium polycarpum & 2 & \\
\hline $\mathrm{O}$ & Lobaria oregana & 1 & \\
\hline $\mathrm{O}$ & Lobaria pulmonaria & 1 & \\
\hline M & Melanelia exasperatula & 5 & 4 \\
\hline $\mathrm{E}$ & Melanelixia fuliginosa & 5 & 7 \\
\hline $\mathrm{E}$ & Melanelixia subargentifera & & 1 \\
\hline $\mathrm{E}$ & Melanelixia subaurifera & 8 & 9 \\
\hline \multirow[t]{2}{*}{$\mathrm{E}$} & Melanohalea subelegantula & 3 & 8 \\
\hline & Melanohalea spp. & & 1 \\
\hline $\mathrm{O}$ & Menegazzia terebrata & 2 & 1 \\
\hline M & Parmelia hygrophila & 10 & 10 \\
\hline $\mathrm{O}$ & Parmelia pseudosulcata & 1 & \\
\hline $\mathrm{E}$ & Parmelia saxatilis & 1 & 2 \\
\hline
\end{tabular}




\begin{tabular}{|c|c|c|c|}
\hline \\
\hline $\mathrm{E}$ & Parmelia sulcata & 13 & 13 \\
\hline $\mathrm{O}$ & Parmotrema arnoldii & 3 & 7 \\
\hline $\mathrm{O}$ & Parmotrema chinense & & 1 \\
\hline M & Peltigera collina & 3 & 1 \\
\hline $\mathrm{O}$ & Peltigera membranacea & 1 & \\
\hline $\mathrm{E}$ & Phaeophyscia nigricans & & 1 \\
\hline $\mathrm{E}$ & Phaeophyscia orbicularis & 1 & 3 \\
\hline $\mathrm{E}$ & Phaeophyscia sciastra & & 1 \\
\hline $\mathrm{E}$ & Physcia adscendens & 9 & 11 \\
\hline $\mathrm{E}$ & Physcia aipolia & 3 & 4 \\
\hline $\mathrm{E}$ & Physcia tenella & 4 & 12 \\
\hline $\mathrm{E}$ & Physcia spp. & & 1 \\
\hline $\mathrm{E}$ & Physconia enteroxantha & 1 & \\
\hline M & Physconia isidiigera & 1 & \\
\hline $\mathrm{E}$ & Physconia perisidiosa & 2 & 2 \\
\hline M & Platismatia glauca & 9 & 9 \\
\hline M & Platismatia herrei & 5 & 3 \\
\hline $\mathrm{E}$ & Punctelia perreticulata & & 2 \\
\hline $\mathrm{E}$ & Ramalina dilacerata & 2 & 2 \\
\hline $\mathrm{E}$ & Ramalina farinacea & 11 & 12 \\
\hline $\mathrm{E}$ & Ramalina subleptocarpha & 3 & 9 \\
\hline $\mathrm{O}$ & Sphaerophorus globosus & 1 & 1 \\
\hline $\mathrm{O}$ & Sticta fuliginosa & 2 & \\
\hline M & Tuckermannopsis chlorophylla & 5 & 3 \\
\hline $\mathrm{O}$ & Tuckermannopsis orbata & 1 & 3 \\
\hline $\mathrm{O}$ & Usnea cornuta & 6 & \\
\hline $\mathrm{O}$ & Usnea filipendula, & 3 & 2 \\
\hline M & Usnea fulvoreagens & 1 & 1 \\
\hline $\mathrm{O}$ & Usnea glabrata & 2 & 5 \\
\hline $\mathrm{O}$ & Usnea longissima & & 1 \\
\hline $\mathrm{O}$ & Usnea scabrata & 1 & 2 \\
\hline $\mathrm{E}$ & Usnea subfloridana & 4 & 6 \\
\hline $\mathrm{O}$ & Usnea wirthii & 5 & 12 \\
\hline & Usnea spp. & 3 & 6 \\
\hline $\mathrm{E}$ & Xanthomendoza fallax & 2 & 4 \\
\hline $\mathrm{E}$ & Xanthoria candelaria & 1 & \\
\hline $\mathrm{E}$ & Xanthoria parietina & 2 & 10 \\
\hline $\mathrm{E}$ & Xanthoria polycarpa & 7 & 10 \\
\hline $\mathrm{E}$ & Xanthoria sp. & & 1 \\
\hline
\end{tabular}


Table 2.3 Lichen species list from paired ground and canopy community surveys of three Portland, Oregon, USA urban forested parks. Detections are the number of times a species was found in ground $(\mathrm{G})$ or canopy $(\mathrm{C})$ surveys. The $\mathrm{N}$ functional group $(\mathrm{E}=$ eutroph, $\mathrm{M}=$ mesotroph, $\mathrm{O}=$ oligotroph) for each species is shown in the leftmost column.

\begin{tabular}{|c|c|c|c|c|c|c|c|}
\hline \multirow[b]{2}{*}{ N-Rating } & \multirow[b]{2}{*}{ Species Code } & \multicolumn{2}{|c|}{ Mt. Tabor Park } & \multicolumn{2}{|c|}{ Forest Park } & \multicolumn{2}{|c|}{ Tryon Creek } \\
\hline & & Ground & Canopy & Ground & Canopy & Ground & Canopy \\
\hline $\mathrm{E}$ & Cancon & 1 & 1 & 1 & 1 & 1 & 1 \\
\hline $\mathrm{E}$ & Clafim & & & & 1 & & \\
\hline $\mathrm{E}$ & Clasqu & & & 1 & & & \\
\hline $\mathrm{O}$ & Clatra & & & 1 & 1 & 1 & \\
\hline E & Evepru & 1 & 1 & 1 & 1 & 1 & 1 \\
\hline M & Hypapi & 1 & & & & & \\
\hline $\mathrm{O}$ & Hypent & & & & & 1 & \\
\hline M & Hypina & 1 & & 1 & 1 & 1 & 1 \\
\hline E & Hypphy & 1 & 1 & 1 & 1 & 1 & 1 \\
\hline M & Hyptub & 1 & 1 & 1 & 1 & 1 & 1 \\
\hline M & Melexau & 1 & 1 & 1 & 1 & & 1 \\
\hline $\mathrm{E}$ & Melful & 1 & 1 & 1 & 1 & & 1 \\
\hline $\mathrm{E}$ & Melsubau & 1 & & & & 1 & \\
\hline $\mathrm{E}$ & Melsube & & & & & 1 & 1 \\
\hline $\mathrm{O}$ & Pararn & 1 & & & & & 1 \\
\hline M & Parhyg & 1 & 1 & 1 & 1 & 1 & 1 \\
\hline $\mathrm{E}$ & Parsax & & & 1 & & & \\
\hline $\mathrm{E}$ & Parsul & 1 & 1 & 1 & 1 & 1 & 1 \\
\hline $\mathrm{E}$ & Phaorb & 1 & & & & & \\
\hline $\mathrm{E}$ & Phyads & 1 & & & 1 & 1 & \\
\hline $\mathrm{E}$ & Phyaip & & & & & 1 & \\
\hline $\mathrm{E}$ & Phyper & 1 & & & & & \\
\hline $\mathrm{E}$ & Phyten & 1 & 1 & 1 & 1 & 1 & 1 \\
\hline M & Plagla & 1 & 1 & 1 & 1 & 1 & 1 \\
\hline M & Plaher & & & 1 & & & \\
\hline $\mathrm{E}$ & Punper & 1 & 1 & & & & 1 \\
\hline $\mathrm{E}$ & Ramdil & & & & & 1 & \\
\hline $\mathrm{E}$ & Ramfar & 1 & 1 & 1 & 1 & 1 & 1 \\
\hline $\mathrm{E}$ & Ramsub & 1 & & & 1 & 1 & \\
\hline M & Tucchl & 1 & 1 & & 1 & & 1 \\
\hline $\mathrm{O}$ & Tucorb & & & & & & 1 \\
\hline E & Unssubl & & & 1 & & & 1 \\
\hline & Usnea sp. & 1 & 1 & & & 1 & 1 \\
\hline $\mathrm{O}$ & Usnfil & & & & & 1 & 1 \\
\hline $\mathrm{O}$ & Usnglaa & & & & & 1 & 1 \\
\hline
\end{tabular}




\begin{tabular}{l|l|l|l|l|l|l|l}
\hline $\mathrm{O}$ & Usnhir & & & & & & 1 \\
$\mathrm{O}$ & Usnwir & 1 & & 1 & 1 & 1 & 1 \\
$\mathrm{E}$ & Xanfal & 1 & & & 1 & 1 & 1 \\
$\mathrm{E}$ & Xanpar & 1 & & & & 1 & \\
$\mathrm{E}$ & Xanpol & 1 & 1 & 1 & 1 & 1 & 1
\end{tabular}


Figure 2.1 Survey of historic (1995-96, 2007) and current (2012-13) lichen biodiversity in 8 urban parks located in Portland, Oregon, USA showed a significant change in lichen community assemblages (species presence and abundance); stress $=0.17$; ANOSIM test statistic $\mathrm{p}=0.005, n=13$. NMDS ordination was used to explore lichen community structure in historic and current surveys. Differing symbols represent survey year, as indicated in figure legend. Bray-Curtis distance measure was for analysis; distances between points are proportional to the dissimilarities between entities. Circles represent 95\% CI.

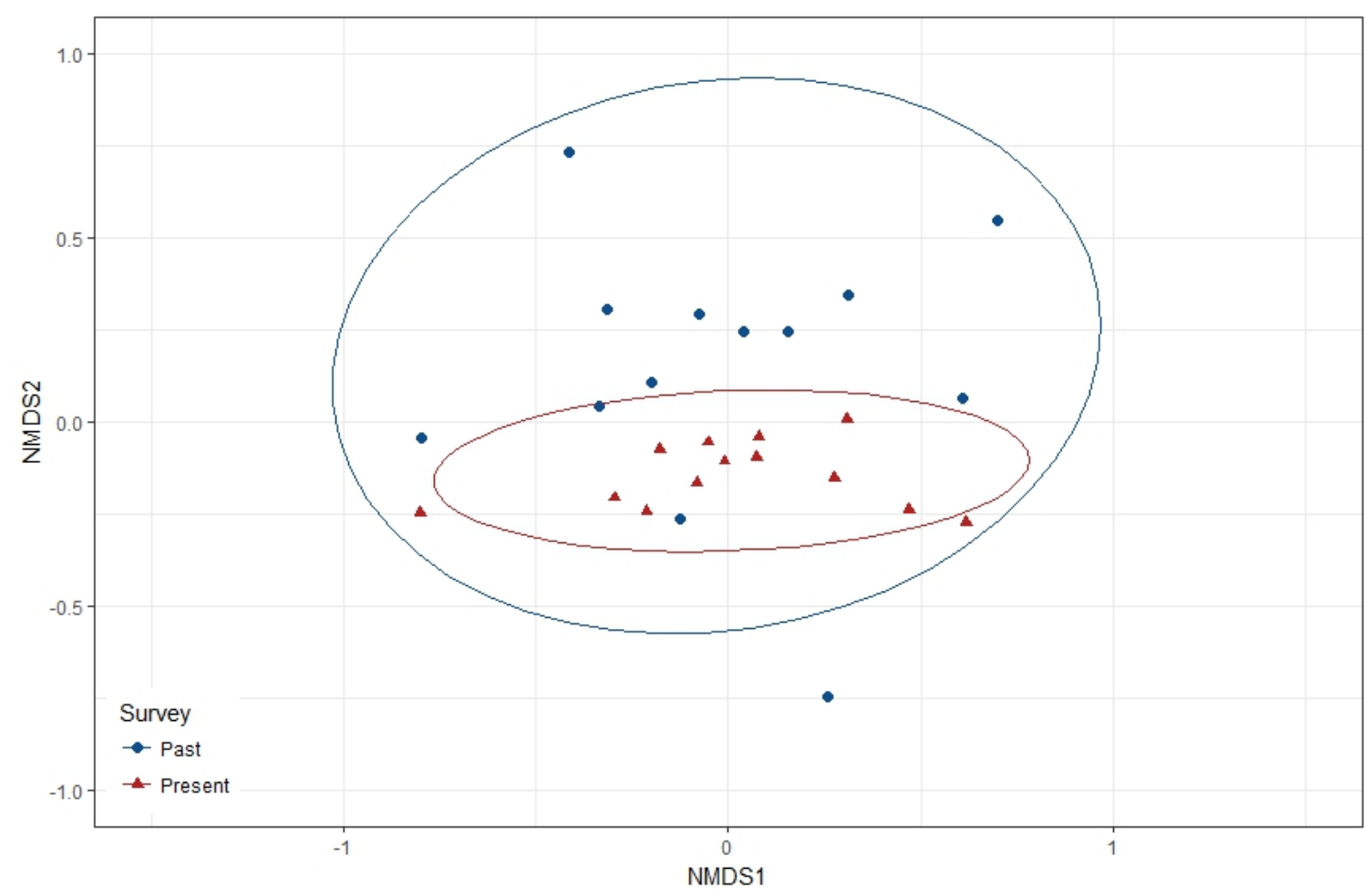


Figure 2.2 Changes in species richness and diversity between matched historic and current lichen community surveys located in eight Portland, Oregon, USA urban parks ( $n=13$ plots). a) Lichen species richness between historic and current lichen surveys. b) Shannon Diversity biodiversity index calculated for historic and current urban park lichen community surveys. Mean values ( \pm SE) shown for parks with replicate plots.
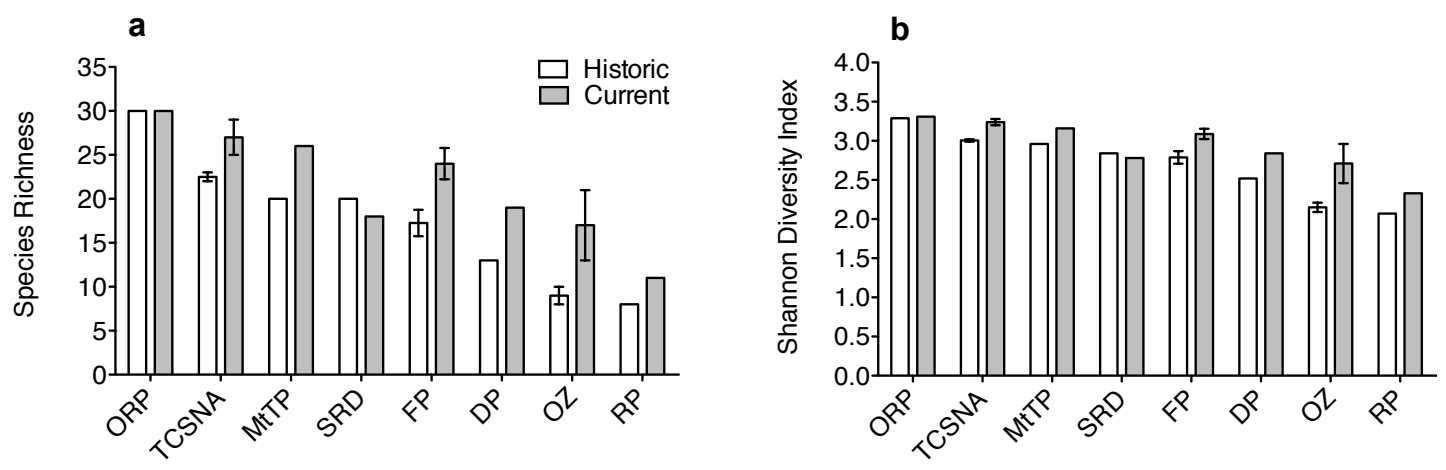
Figure 2.3 a) Mean ( \pm SE) number of lichen species in historic and current ground-level lichen community surveys in eight urban parks located in Portland, Oregon, USA. A significant increase in number of eutrophic lichen species was revealed between current and historic surveys $(\mathrm{p}=0.001, n=13)$; b) Mean $( \pm \mathrm{SE})$ relative frequency $(\%)$ of lichen species in historic and current ground-level lichen community surveys; lichen species are categorized by functional $\mathrm{N}$ rating; eutroph or nitrophilous $\left(>4.6 \mathrm{~kg} \mathrm{~N} / \mathrm{ha}^{-1} / \mathrm{yr}^{-1}\right)$, mesotroph $\left(2.5-4.5 \mathrm{~kg} \mathrm{~N} / \mathrm{ha}^{-1} / \mathrm{yr}^{-1}\right)$, or oligotroph $\left(<2.4 \mathrm{~kg} \mathrm{~N} / \mathrm{ha}^{-1} / \mathrm{yr}^{-1}\right)$. Hashed line indicates $>35 \%$ proportion of eutrophic species, signifying elevated ecosystem $\mathrm{N}$ inputs.
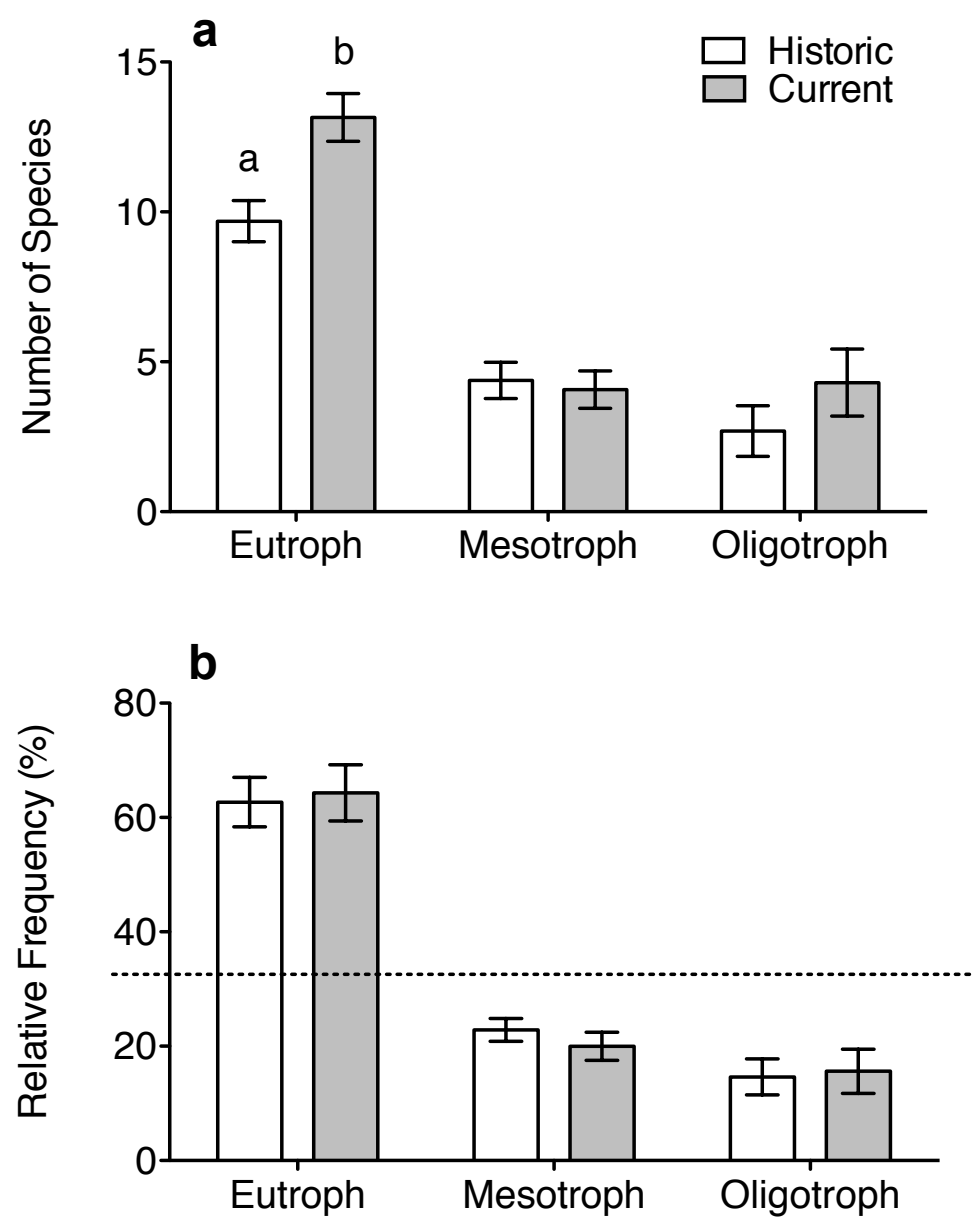
Figure 2.4 Urban Park historic and current survey air scores derived from plot scores on lichen community gradients using non-metric multidimensional scaling ordination. Mean values $( \pm \mathrm{SE})$ shown in parks with replicate plots. Highest air scores indicate the most polluted sites. No significant difference occurred between historic and current park air scores ( $\mathrm{p}=0.99, n=13)$, in an 18-year reassessment of matched historic and current urban park lichen community surveys in 8 urban parks located in Portland, OR, USA.

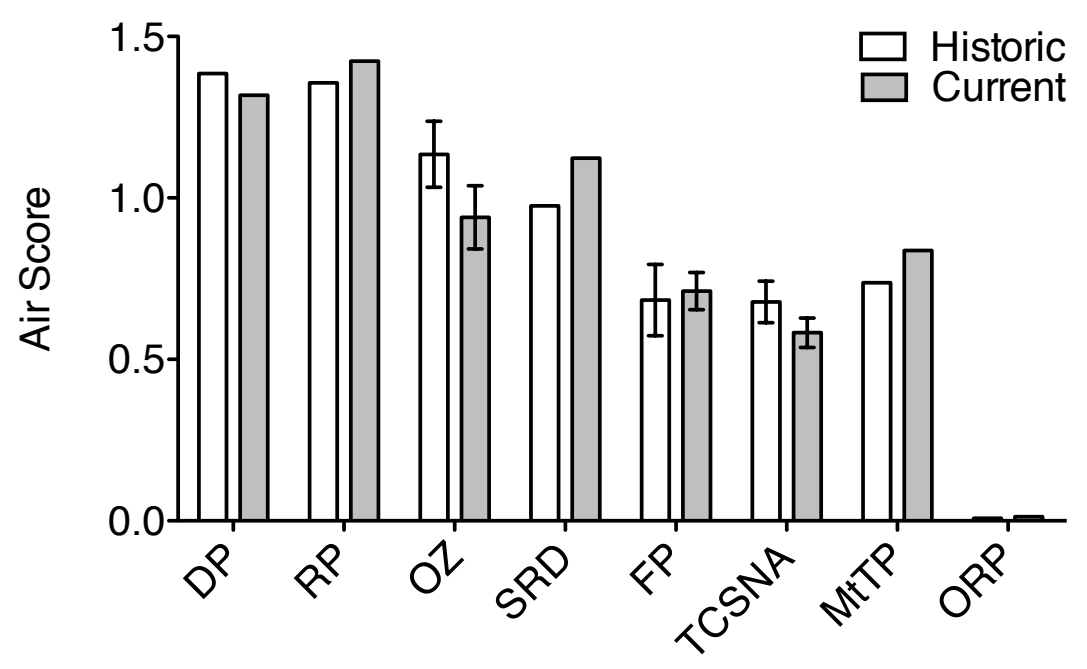


Figure 2.5 Mean $( \pm \mathrm{SE})$ relative frequency $(\%)$ of paired canopy and ground level lichen community surveys in three urban parks located in Portland, Oregon, USA indicates a highly eutrophied lichen community. No significant difference occurred between ground and canopy surveys $(\mathrm{p}=0.99, n=9)$. Lichen species are grouped by functional $\mathrm{N}$ rating; eutroph or nitrophilous $\left(>4.6 \mathrm{~kg} \mathrm{~N} / \mathrm{ha}^{-1} / \mathrm{yr}^{-1}\right)$, mesotroph $\left(2.5-4.5 \mathrm{~kg} \mathrm{~N} / \mathrm{ha}^{-1} / \mathrm{yr}^{-1}\right)$, or oligotroph $\left(<2.4 \mathrm{~kg} \mathrm{~N} / \mathrm{ha}^{-1} / \mathrm{yr}^{-1}\right)$. Hashed line indicates $>35 \%$ proportion of eutrophic species, signifying elevated ecosystem $\mathrm{N}$ inputs.

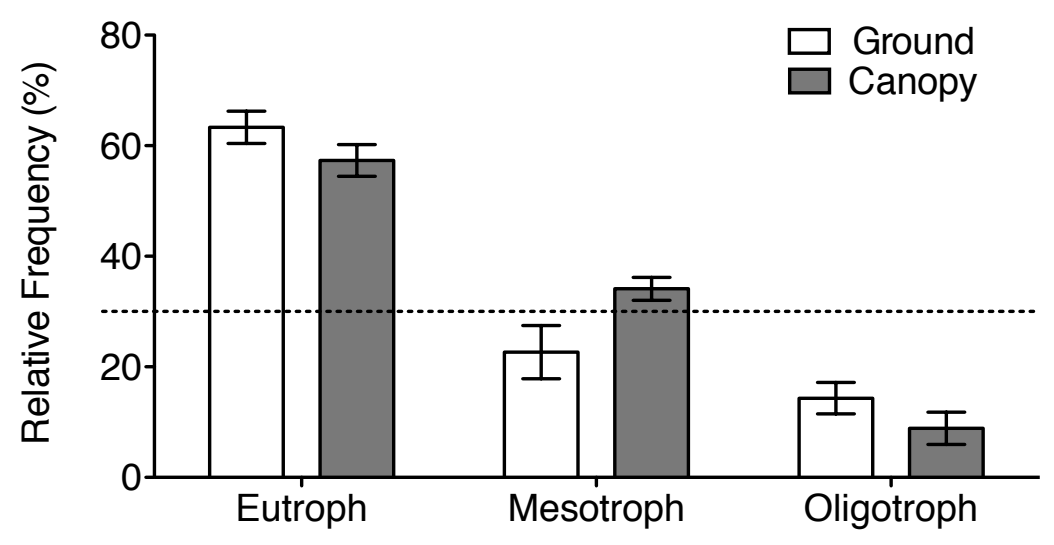


Figure 2.6 a) Mean ( \pm SE) number of lichen species categorized by ecological classification group in matched historic and current ground-based lichen community surveys in eight urban parks located in Portland, Oregon, USA; significant increase in number of eutrophic lichen species $(\mathrm{p}=0.001, n=13)$ and number of green algal species $(\mathrm{p}=0.001, n=13)$ was observed between historic and current surveys; b) Mean ( $\pm \mathrm{SE})$ number of lichen species categorized by ecological group in paired ground and canopy surveys in three urban parks located in Portland, Oregon, USA; canopy surveys are a mean of three vertical sampling layers (top, mid, low canopy); lichen species are categorized by ecological group; eutroph (Candelaria sp., Physcia sp., Xanthoria sp.), green algal (Hypogymnia sp., Platismatia sp.), alectorioid (Alectoria sp., Bryoria sp., Usnea sp.), and cyanolichens (Lobaria sp.).
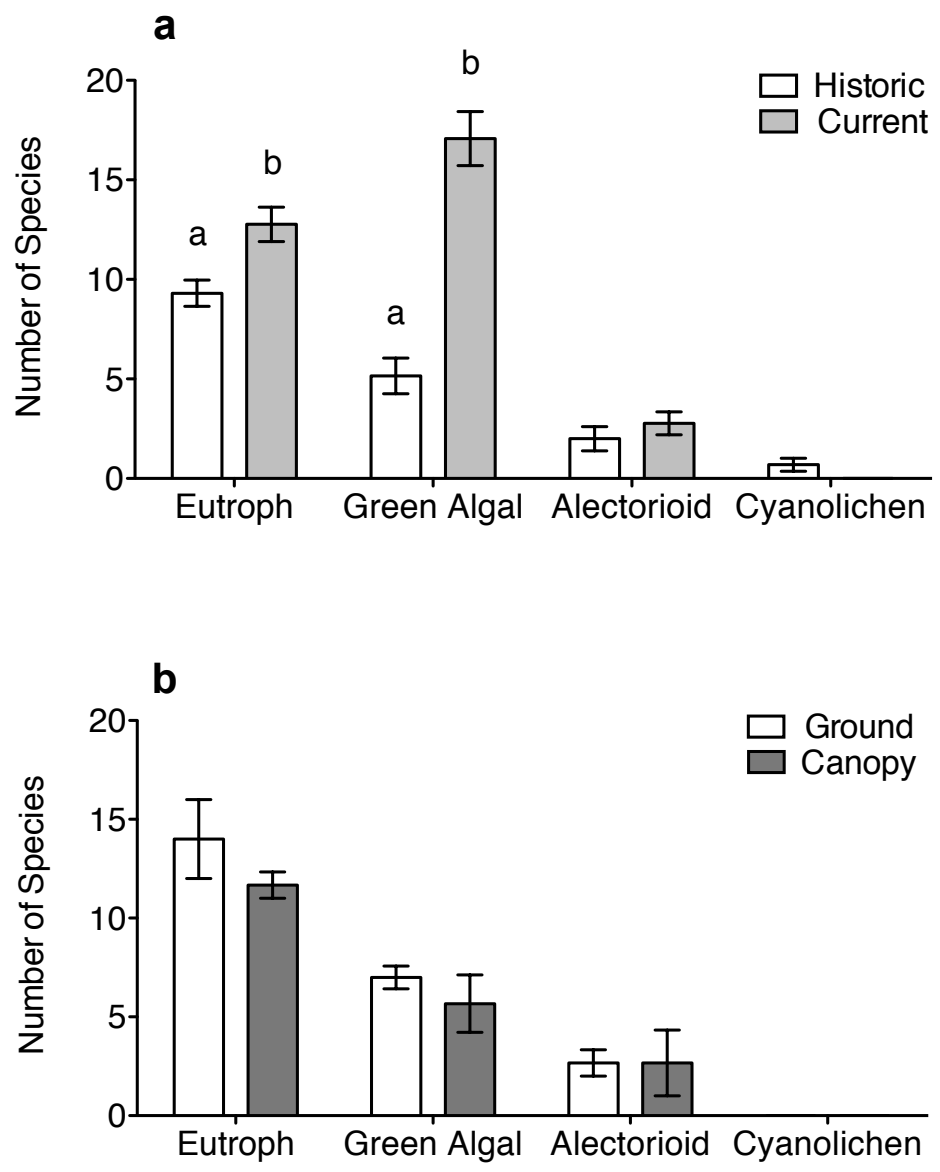


\title{
Chapter 3
}

\section{Implications of Increasing Urbanization on Canopy-Dwelling Epiphyte Communities in Tall Pseudotsuga menziesii in the Pacific Northwest, USA}

\begin{abstract}
The world is rapidly urbanizing and the response of forest ecosystems under this increasing anthropogenic input is of utmost concern. Forest ecosystems respond to changes in multiple ways, the biodiversity and resiliency of an ecosystem can predict the capacity of an ecosystem to withstand change and continue to perform essential ecosystem processes. In the Pacific Northwest region of the USA, the forest canopy houses an important biodiversity of non-vascular epiphytes (lichens and bryophytes), which contribute a number of important ecosystem processes. Although ecologically important, epiphytic lichens and bryophytes are especially sensitive to heavy metal and nutrient deposition resulting from urban pollution. Here we present the results of the first tall tree canopy study across a regional gradient of urbanization near Portland, Oregon, USA. We found dramatic shifts in urban canopy epiphyte communities in tall tree canopies, occurring at all layers of stratification, including the total loss of sensitive, nitrogen-fixing lichens within the most urbanized areas. We further found evidence that urban canopy-dwelling epiphytes may be serving important roles in the interception of atmospheric metal and nutrient deposition in urban forest environments. Contrary to our hypotheses, canopy-dwelling microarthropod communities, extracted from canopy lichens and bryophytes assemblages, appeared less impacted across the study gradient and no significant community shifts occurred with shifting epiphyte assemblages. Although the sensitivity of epiphytic lichens and bryophytes makes these species
\end{abstract}


particularly vulnerable to atmospheric pollution, to date there has been no comprehensive study to assess the impacts of urbanization on PNW forest canopy epiphytic communities and canopy nutrient cycling, despite continued growth in transportation and transportation-sourced pollutants throughout the PNW. We discuss the ecological impacts of urban-induced shifts in epiphyte communities on PNW biodiversity, forest $\mathrm{N}$ cycles and canopy microclimates regulation.

\section{Introduction}

The growth of urbanization and air pollution is a rising concern in the Pacific Northwest region of the United States. Generally considered a pristine and largely forested area, the Pacific Northwest (PNW) is undergoing rapid urbanization and expanding population density. From 2010-2015, Oregon and Washington populations increased by 5\% and 7\%, to 191,000 and 427,000 respectively (US Census Bureau Population Division 2016). At the national scale, the PNW region has had historically clean air, in part attributed to a reliance on hydropower. Yet, while the PNW is fairly clean, it has begun to mimic other parts of the US and Europe with longer histories of air pollution (Sigal and Nash III 1983, Van Herk et al. 2003, Geiser and Neitlich 2007). PNW lichen communities have begun to show the adverse effects of nitrogen pollution, where sensitive taxa are replace by urban, pollution tolerant species (Fenn et al. 2003b, Geiser and Neitlich 2007). Increasing N deposition in the PNW is related to both the expansion of urban areas, and the transpacific transport of N oxides from Asia (Geiser and Neitlich 2007, Fenn et al. 2013). Thus, rapid population growth, and the associated increases in the transportation sector, may threaten the region's history of clean air. 
Douglas-fir (Pseudotsuga menziesii (Mirb.) Franco) is a dominant forest type and economically valuable tree species in the PNW region, in Oregon alone it comprises 51 percent of total above-ground tree biomass on forested lands (Zhou and Hemstrom 2009). P. menziesii can grow to exceed heights of $60 \mathrm{~m}$, making this iconic tall tree species the setting of numerous forest canopy studies in the Northwest (McCune 1993, McCune et al. 1997, Sillett and Rambo 2000, Sillett et al. 2000a, 2000b). Forest canopies in the PNW region have been shown to hold an impressive biomass and biodiversity of non-vascular epiphytes (i.e. lichens and bryophytes) (Pike et al. 1977, Binkley and Graham 1981, McCune 1993, 1994, Sillett and Rambo 2000). Together, these canopy epiphyte communities contribute a number of essential ecosystem functions in PNW forests, such as providing habitat for invertebrates, nesting material and forage substrate for birds, regulation of tree canopy microclimate, and essential nitrogen fixation (Coxson and Nadkarni 1995, Pettersson et al. 1995, McCune 2000, Sillett and Rambo 2000, Antoine 2004a, Pypker et al. 2006, Wolf 2009) - which collectively may be at risk given urbaninduced shifts in epiphyte community composition.

The highest epiphytic lichen biomass of any temperate forest ecosystem occurs in the PNW (DellaSala et al. 2015) and the retained biodiversity of oligotrophic lichen species can be related to a history of clean air (Goward and Arsenault 2000). Nutrient ratios are predicted to be a key determinant of species composition in oligotrophic ecosystems, consistent with resource competition theory (Tilman 1982), therefore increasing $\mathrm{N}$ deposition will result in lichen species shifts, which has been documented in a number of PNW regional studies (Fenn et al. 2003a, Geiser and Neitlich 2007, Root et al. 2015). Epiphytic lichens are sensitive indicators of ecosystem change and methods 
using both lichen community response and lichen tissue accumulation of nutrients and heavy metals have been widely used in the PNW region to assess ecosystem harm (Jovan and McCune 2005, Geiser and Neitlich 2007, Geiser et al. 2010, Root et al. 2013, 2015). The development of regional gradient models allow lichen community response to indicate shifts in climate and $\mathrm{N}$ deposition, as isolated from other environmental gradient responses (Geiser and Neitlich 2007, Root et al. 2013).

Urbanization effects the broader regional environment. Regions downwind from large urban areas also see increases in air pollution, via the transport of urban air pollutants (Goudie 2000, Geiser et al. 2010, Fenn et al. 2013). In the PNW region, predominate winds transport clean air masses from the Pacific Ocean over the urban metropolises, which continue towards the forested and wilderness areas surrounding the Cascade crest. Early work by Denison (1973) showed this effect on downwind lichen communities and more recent work by Geiser and Neitlich (2007) has further documented these regional pollutant regional. The extent of the urban effect can be difficult to detect since forested areas are usually absent in ex-urban areas that lie between urban areas and remote sites. Additionally, the chemical transformations of many urban air pollutants can add to the difficulty of detecting impacts in downwind ecosystems. We propose for the first time, using the stratified vertical habitat of tall conifer trees to detect the early signs of urban impact across a regional gradient of urbanization, as we hypothesize the canopy ecosystem lies in the areas of highest vulnerability from urban air pollutant transport.

Tree canopies lie in a unique interface with the surrounding atmosphere (Ozanne et al. 2003). Effects on canopy biota in the PNW, as a result of anthropogenic activities, 
may have profound effects on canopy biodiversity and the capacity of canopy ecosystems to contribute essential ecosystem processes. Undoubtedly, change is a part of every ecosystem and PNW forests are adapted to many natural changes (e.g. fire, landslides, insect outbreaks), but how ecosystems will respond to anthropogenic change relies upon the individual components that make up the system. Therefore, effects on biodiversity can affect the thresholds of ecosystem resiliency - which is the capacity of an ecosystem to carry out essential ecosystem processes (Chapin et al. 2000). As urbanization continues across the globe, understanding human influences on downwind forest ecosystems, and forest canopy ecosystems in particular is ever critical in this rapidly changing global environment.

In this study we present the first tall tree canopy-based study examining the effects of regional urbanization on canopy epiphyte communities in tall P. menziesii trees (tree heights $>60 \mathrm{~m}$ ). Here we aimed to examine the ecology of stratified tall tree canopy environments and test four interconnected hypotheses, rooted in results from prior ground-based lichen community studies (see Chapter 2): 1) early signs of ecosystem impact may be detected in canopy-dwelling epiphyte communities before impacts are detected in ground level surveys, due to the canopy-atmosphere interface; 2) stratified gradients of lichen species functional $\mathrm{N}$ groupings (eutroph, mesotroph, and oligotroph) may be present in situ in tall tree canopies, related to the depositional patterns of atmospheric urban air pollutants; 3) if strong vertical metal and nutrient depositional patterns occur, we expect to reveal these patterns using stratified canopy collections of lichen tissue accumulated metals and nutrients; 4) we predict that canopy epiphyte dwelling microarthropods communities will track with any observed shifts in canopy 
epiphyte communities. Alterations of canopy biodiversity along gradients of urbanization may impact the resiliency of PNW forest ecosystems, because many essential canopy ecosystem processes (i.e. $\mathrm{N}$-fixation, microclimate regulation, habitat) have largely been associated with communities of 'pristine' canopy epiphytes in the PNW.

\section{Materials and Methods}

\section{Study area}

A $133 \mathrm{~km}$ transect was established along an urban to remote gradient, originating in Portland, Oregon and extending SE towards the crest of the Cascade Mountain Range. The transect follows the trajectory of dominant regional air patterns and established measurements of regional $\mathrm{N}$ deposition and climatic patterns (Denison, W.C. and Carpenter 1973, George et al. 2005, Geiser and Neitlich 2007, Geiser et al. 2010). Forest areas were assigned to urban, mid, and remote types based on air scores derived from ground-based lichen community plot data using the regional USFS lichen and air quality online database (Root et al. 2013, USDA-Forest Service 2016) and also factoring in density of human population and distance from the urban core. Forested area where mature Pseudotsuga menziesii was the dominant overstory tree was used as a site selection criterion.

At each forest area (urban, mid, remote), three P. menziesii were chosen for arboreal study and a matched ground level 0.38 ha circular area lichen survey plot was established (USDA-Forest Service 2004), yielding nine study plots total. The urban plots were located in Forest Park, Portland, Oregon. The mid plots were located in the Roaring 
River Wilderness, Clackamas County, Oregon. Remote plots were located in the Clackamas River Wilderness, Clackamas County, Oregon.

\section{Ground-based lichen community surveys}

Ground-based surveys of epiphytic macrolichens were conducted according to the widely accepted Forest Inventory Analysis (FIA) lichen community protocol (Mccune et al. 1997, USDA-Forest Service 2004), where circular 0.38ha area plots are surveyed and each epiphytic macrolichen is vouchered and an ocular abundance value is recorded. Ground level survey plots were established at the base of each study tree, using the study tree as plot center.

\section{Canopy-based lichen community surveys}

Tall Pseudotsuga menziesii trees were selected to assess stratification of lichen species as a response to vertical canopy air quality gradients. Trees which exceeded $60 \mathrm{~m}$ height and $>100 \mathrm{~cm} \mathrm{DBH}$, with intact crowns and suitable for climbing were selected for study. Trees were rigged for climbing by launching a weighted throwball attached to hightensile strength throwline over suitable climbing limbs in the uppermost canopy. Climbing ropes were then pulled over to allow ascent into the crown. Single rope climbing techniques (SRT) were used to access the crown and short canopy rope laynards were used for in-canopy movements. Tree height was measured to the top of the most apical portion of the crown; tree crown was measured from the lowest live branch whorl to the most apical portion of the crown. The crown was divided into three stratified canopy sampling sections: top crown, mid crown, and lower crown. I used a modified 
FIA lichen community protocol survey and lichen tissue collection (Geiser 2004, USDAForest Service 2004) to describe urban arboreal lichen communities at each of three canopy stratification sections, in each study tree. Each canopy section was surveyed for a maximum of 1 hour, or until no new species had been recorded in a 10 min period. Epiphytic lichens were collected from branches and bole within the stratified canopy section. Each unique species was vouchered and ocular abundance was recorded (see USDA- Forest Service 2004).

Lichen community data (presence/absence and abundance) from both the ground and canopy based FIA surveys were inputted into the larger regional PNW gradient model, which relates lichen community gradients to air quality, climate and environmental variables across 1549 regional surveys in Oregon and Washington, from the Pacific Ocean to the Cascade Crest (Geiser and Neitlich 2007) . I applied this model and calculated air quality scores for both ground level and canopy lichen community surveys. All lichens were identified using McCune and Geiser (2003) from morphology, chemical spot test, and thin layer chromatography.

\section{Lichen elemental data}

At each of the three canopy stratification sections, $5-10 \mathrm{~g}$ of two epiphytic lichen species were collected, where possible, for total sulfur, nitrogen and cation analysis following methods of Geiser (2004). A matched ground level collection of the two species was made following standard USFS methods (Geiser 2004). The target species was Platismatia glauca, but since the frequency and overall health of this species decreases in highly urbanized areas (National Lichens \& Air Quality Database \& Clearinghouse 
2016), we also collected Parmelia sulcata, a frequent and abundant species detected in the study area. Both species varied in presence, abundance and health in the study trees. Sterile gloves were used to sample lichens from the bole and branches of the study trees at each canopy stratification sections. Because $P$. sulcata has not yet been widely used as a target species for tissue accumulation in the PNW, we further collected paired collections of $P$. sulcata and $P$. glauca across a larger regional deposition gradient, as identified in Geiser and Neitlich 2007. We linearly regressed combustion analyzed $\mathrm{N}$ and S content (\%) of P. sulcata and P. glauca and the correlation indicated $\left(\mathrm{r}^{2}=0.90846\right)$ the strength of the relationship. We further tested binned values of $\mathrm{N}$ and $\mathrm{S}$ content (\%) for $P$. glauca and $P$. sulcata for all urban collections and found values did not differ significantly, which allowed us to pool all N and S (\%) values for both species across the site gradient. The strong correlation between species was not observed for elemental accumulation of heavy metals, therefore all elemental analyses are reported from only $P$. glauca tissue collections.

Lichen samples were cleaned of non-lichen debris and necrotic tissue and sent to the USFS Northern Research Station, Forest Science Analytic Laboratory in Grand Rapids Minnesota. Samples were dried and homogenized to a constant weight and total $\mathrm{C}, \mathrm{N}$, and $\mathrm{S}$ was determined by combustion analysis as percent (\%) dry weight using a LECO FP-528. ICP-AES analysis of sample digestion was used to determine heavy metal accumulation as ppm $(\mathrm{mg} / \mathrm{kg})$ per dry weight.

Measured mean +/- std err total $\mathrm{C}, \mathrm{N}$, and $\mathrm{S}$ concentrations in a certified barley check standard (Leco 502-277) were $44.91+/-0.03,1.734+/-0.004$, and $0.149+/-0.001$, respectively. These are all within the Leco-certified ranges of these elements (C: 44.58 - 
45.63, N: $1.66-1.81, \mathrm{~S}: 0.137-0.159)$, indicating the combustion analysis data for these elements were highly accurate.

\section{Canopy-based bryophyte community surveys}

Arboreal bryophytes were collected using the same modified FIA lichen community protocol survey as described above. While this technique has not been used for estimating canopy bryophyte communities or their abundance, it nevertheless provides a snapshot of the canopy species that occurred in the canopy stratification sections across the study area. Bryophytes were identified taxonomically in PSU laboratories and confirmed by an expert of local bryophyte flora.

\section{Canopy epiphyte associated microarthropod communities}

At the lowest layer of the canopy, an approximate 3-6g mass of substrate assemblages (lichens \& bryophytes) were collected from canopy branches at $1 \mathrm{~m}$ from the bole in each cardinal direction (NSEW) and confirmed in situ with a spring balance. Samples were then stored in a cooler and transported to PSU laboratories the same day as sample collection occurred. Microarthropods were then extracted with berlese funnels into $75 \%$ ethanol for up to five days, until substrate patches were completely desiccated of all moisture. Following extraction, substrate samples were then transferred to paper bags and dried for $24 \mathrm{hrs}$ at $60 \mathrm{C}$ in plant drying over and dry weights were measured and percent moisture content (expressed as percent dwt) was calculated gravimetrically by the change in mass. 
Extracted microarthropods were sorted taxonomically by order into the following groups: Oribatida, Other mites (Mesostigmata \& Prostigmata), Collembola, and other microarthropods (Pseudoscorpiones, Araneae, Diptera, Blattodea, Larvae, Coleoptera, Mallophaga, Nematoda, Lepidoptera, and Thysanoptera). Microarthropod abundance was expressed as number of individuals per gram dry weight of substrate. Substrate samples of lichens and bryophytes were identified taxonomically to species and relative abundance quantified as a proportion (\%) of total sample.

\section{Statistical Analyses}

All analyses were conducted using Graph Pad Prism (Version 5.0 for Mac Graph Pad Prism 2007) unless otherwise stated. Two-way ANOVA were performed to determine the effect of site location (urban, mid, remote) and vertical stratification (top, mid, low canopy) on species richness \& biodiversity, lichen community assemblages (as categorized by functional $\mathrm{N}$ rating), lichen tissue accumulated heavy metals and canopy epiphyte associated microarthropod communities. Tukey's tests were used to determine significance among factors. One-way ANOVA were performed to determine the effect of site location and vertical stratification on lichen community derived air quality scores (AQ scores) and lichen tissue accumulated macronutrients, using Tukey's test to determine significant factors. These data were assessed to fit the assumptions of the ANOVA model and transformations made where indicated. Discrimination between $\mathrm{N}$ functional groups (eutroph or nitrophilous ( $\left.>4.6 \mathrm{~kg} \mathrm{~N} / \mathrm{ha}^{-1} / \mathrm{yr}^{-1}\right)$, mesotroph $(2.5-4.5 \mathrm{~kg}$ $\left.\mathrm{N} / \mathrm{ha}^{-1} / \mathrm{yr}^{-1}\right)$, or oligotroph $\left(<2.4 \mathrm{~kg} \mathrm{~N} / \mathrm{ha}^{-1} / \mathrm{yr}^{-1}\right)$ followed McCune and Geiser (2003). 
We used the Geiser \& Neitlich (2007) regional lichen, air quality and climate model to ordinate lichen community data from our ground and canopy based surveys within the larger archive of regional sites $(1,416,0.4$ ha regional forested plots) and generated air scores (AQ scores) for our surveys with the parameters described in Geiser \& Neitlich (2007), using non-metric multidimensional scaling (NMS) in PC-ORD (McCune \& Mefford 1999). Positive air score values indicate polluted sites, while negative air score values indicate clean sites.

\section{Results}

\section{Ground \& Canopy-based lichen community surveys}

We found 87 total macrolichen species from combined ground and canopy surveys; 28 species were unique to ground-level surveys and 13 species were unique to only canopy surveys (Table 3.1). The urban site surveys yielded 29 total species from ground-level surveys and 23 species from canopy surveys. The mid site had 47 total species from ground-level surveys and 39 from canopy surveys, and the remote site had 48 total species from ground-level surveys and 38 from canopy surveys. Species richness was significantly affected by site (Figure 3.1a, two-way ANOVA, $\mathrm{F}=25.13, \mathrm{p}=0.001, n=3$ ) and by stratification (ground, low canopy, mid canopy, top canopy) (Figure 3.1a, twoway ANOVA, $\mathrm{F}=60.66, \mathrm{p}=0.001, n=9$ ). The urban site showed significantly less richness than mid and remote sites (Figure 3.1a, two-way ANOVA, $\mathrm{F}=25.13, \mathrm{p}=0.001, n=3$ ). In regards to stratification, ground-based sites had significantly higher species richness than canopy surveys at the mid [mean $=33]$ and remote sites [mean $=33]$, contrasted by relatively low ground-based richness in the urban site [mean=19] (Figure 3.1a, two-way 
ANOVA, $\mathrm{F}=60.66, \mathrm{p}=0.001, n=9)$. Within canopy richness differed significantly with stratification at the mid and remote sites, but less so in the urban site, revealing that urban canopy lichen communities are more similar to their matched ground level surveys (Figure 3.1a, two-way ANOVA, $\mathrm{F}=3.32, \mathrm{p}=0.02, n=9$ ); canopy species richness was highest in the mid and remote sites [mean=17] and lowest in the urban site [mean=9]. Lichen biodiversity, calculated using the Shannon-Wiener diversity index, was significantly lower in the urban site than in mid and remotes sites (Figure 3.1b, two-way ANOVA, $\mathrm{F}=17.48, \mathrm{p}=0.001, n=3$ ); biodiversity was found to be higher in ground-based surveys than canopy surveys at the mid and remote site locations (Figure 3.1b, two-way ANOVA, $\mathrm{F}=39.07, \mathrm{p}=0.001, n=9)$ and lowest in the upper canopies of the urban trees sites (Figure 3.1b, two-way ANOVA, $\mathrm{F}=39.07, \mathrm{p}=0.001, n=9$ ).

Urban epiphytic lichen communities, both ground and canopy, had a significantly higher frequency of eutrophic lichen species (Figure 3.2, two-way ANOVA, F=4.77, $\mathrm{p}=0.01, n=9$ ) [mean ground surveys showed proportion of $60 \%$ eutrophic species; mean canopy surveys showed $61 \%$ eutrophic species] than mid and remote sites and significantly fewer oligotrophic species (Figure 3.2, two-way ANOVA, $F=4.77, p=0.01$, $n=9$ ) [mean urban ground surveys showed 14\% oligotrophic species; mean canopy surveys showed $11 \%$ oligotrophic species]. The urban sites far exceeded the $30 \%$ community threshold considered for eutrophied lichen communities both in ground and arboreal surveys (see Figure 3.2). No significant differences occurred in any site between ground-based and matched canopy surveys, and no strong trends from stratification layers emerged (two-way ANOVA, $\mathrm{F}=0, \mathrm{p}=1.0, n=9$ ). Strong compositional differences 
between urban lichen community composition and mid and remote lichen communities were revealed, as indicated by lichen species $\mathrm{N}$ functional groups (Figure 3.2).

Ground-based site and canopy stratification AQ scores were derived from the larger, PNW lichen regional NMS ordination model (Geiser and Neitlich 2007), where positive air scores values indicate the most polluted sites and negative air scores indicate clean sites. The highest air scores occurred in urban ground and canopy surveys (Figure 3.3). Ground-based, lichen community AQ scores were significantly higher (Figure 3.3, two-way ANOVA, $\mathrm{F}=93.57, \mathrm{p}=0.001, n=3$ ) than canopy lichen community AQ scores at the mid site location. Collectively, we saw that ground-based FIA survey methods accurately reflect matched, large conifer canopy surveys, but may yield an overestimation of species richness and therefore lichen community generated AQ scores in sites located along the urban peripheral.

\section{Lichen elemental data}

We found that N and S (\%) tissue concentrations of ground-level collected Platismatia glauca and Parmelia sulcata were highest in the urban center and decreased along the site gradient. Tissue concentrations of $\mathrm{N}$ and $\mathrm{S}(\%)$ were highest in the urban sites $(0.8 \%$ and $0.09 \%)$ and decreased to background concentration values in the mid $(0.4 \%$ and $0.04 \%)$ and remote sites $(0.3 \%$ and $0.03 \%)$ (Figure 3.4). Ground-level collected lichen tissues in the urban sites exceeded $\mathrm{N}$ and $\mathrm{S}(\%)$ threshold values for elemental concentrations of $P$. glauca, $0.6 \%$ and $0.07 \%$ respectively, as determined from lichen tissues collected across regional background sites in PNW forests (Oregon, Washington, and Alaska National Forests). 
Much to our surprise, canopy-based collections of $P$. glauca and $P$. sulcata were significantly higher in $\mathrm{N}(\%)$ content, at all stratified layers (top, mid, and low crown; 1.7, 1.6, and $1.4 \%$ respectively), than the matched ground-based collections (Figure 3.4, ANOVA, $\mathrm{F}=50.09, \mathrm{p}=0.001, n=3)$, revealing $\mathrm{N}(\%)$ values which were two-fold higher than the ground-based collections. There was no significant difference between $\mathrm{N}$ concentrations within the stratified canopy tissue collections. Canopy-based collections also revealed S (\%) values which were significantly higher, at all stratified layers (top, mid, and low crown; $0.15,0.13$, and $0.13 \%$ respectively) than matched ground-based collections (Figure 3.4, ANOVA, F=35.86, $\mathrm{p}=0.001, n=3$ ). No significant differences occurred between $\mathrm{S}$ concentrations within the stratified canopy collections. We calculated C:N ratios for all pooled values of $P$. glauca and $P$. sulcata and found that each site (urban, mid and remote) differed significantly in calculated lichen tissue $\mathrm{C}: \mathrm{N}$ ratio (Figure 3.5, ANOVA, $\mathrm{F}=87.57, \mathrm{p}=0.001, n=15$ ).

Ground-based collections of $P$. glauca from the urban sites revealed seven metals $(\mathrm{B}, \mathrm{Co}, \mathrm{Cr}, \mathrm{Cu}, \mathrm{Ni}, \mathrm{Pb}, \& \mathrm{Zn}$ ), all of transportation and/or industrial origin, which exceeded threshold values for deposition levels determined for clean sites in PNW forested ecosystems (National Lichens \& Air Quality Database \& Clearinghouse 2016) (Table 2.3). Interestingly, ground-based collections at the mid showed two metals that exceeded clean site threshold values $(\mathrm{Cr} \& \mathrm{Cu})$ (Table 2.4). P. glauca tissue collections from the stratified canopy collections revealed two metals $(\mathrm{Cu} \& \mathrm{~V})$ in the urban canopies which exceeded regional threshold values. Additionally, Arsenic (As) was detected at moderate values in the top layer of the urban trees. Regional thresholds values 
for As have not been established, the range of values $(0.53-0.94 \mathrm{ppm})$ used here are derived from values determined in a Portland area study (Donovan et al. 2016).

Metal data was log transformed and outliers were removed to fit the assumptions of an ANOVA model, which allowed us to reveal the effect of site location and canopy stratification on metal accumulation in P. glauca. We found that ground level collections in urban sites had significantly higher concentrations of four metals (Fe, $\mathrm{Mn}, \mathrm{Ni}$, and $\mathrm{Pb}$ ) than mid and remote sites (Table 3.5, two-way ANOVA, $\mathrm{F}=5.03, \mathrm{p}=0.01, n=3$ ). No significant differences occurred in stratified canopy collections across site location or within canopy (Table 3.5, two-way ANOVA, $\mathrm{F}=0.76, \mathrm{p}=0.63, n=3$ ).

\section{Canopy-based bryophyte community surveys}

Nine species of canopy bryophytes were recorded in the canopy-based surveys along the regional urbanization gradient. The most common urban canopy species were Orthotrichum lyellii and Dicranoweisia cerrata. The most common species detected in the mid site canopies were Dicranum tauricum, Antitrichia curtipendula and Hypnum circinale and in the remote site canopies were Dicranum tauricum, Antitrichia curtipendula, and Isothecium cristatum (Table 3.2). More work is needed to determine the potential use of these species as ecosystem indicators along gradients of urbanization.

\section{Canopy epiphyte associated microarthropod communities}

The mean number of microarthropods per $\mathrm{g} / \mathrm{DW}$ of substrate and the relative abundance of dominant taxa did not differ significantly from Berlese funnel extractions of canopydwelling lichen and bryophyte assemblages sampled across the site gradient (Figure. 
3.6a, two-way ANOVA, $\mathrm{F}=0.21, \mathrm{p}=0.81, n=12$; Figure 3.6b, two-way ANOVA, $\mathrm{F}=0.84$, $\mathrm{p}=0.44, n=12$ ). We were limited by our relatively small sample size and suspect that a larger sampling approach may reveal patterns, which could be explored further in future work.

\section{Discussion}

This study is the first tall tree canopy-based study, to our knowledge, showing the effects of regional urbanization on canopy epiphyte communities in tall P. menziesii trees (tree heights $>60 \mathrm{~m})$. We aimed to examine stratified tall tree canopies and test the hypothesis that early signs of ecosystem impact may be detected in canopy-dwelling lichen communities, before effects are detected in ground level surveys, due to the transport of atmospheric urban air pollutants. We further examined tall tree canopies to see if vertical gradients existed in canopy stratification of species functional $\mathrm{N}$ groupings (eutroph, mesotroph, and oligotroph) in large tree crowns, similar to observations made in regional, ground-based lichen community surveys in the PNW region. Our results revealed dramatic shifts in lichen community composition, both in the canopy of tall trees and in matched ground-based surveys, across a study area, similar to results from other PNW ground-based lichen community studies surrounding urban centers (Denison, W.C. and Carpenter 1973, Geiser and Neitlich 2007). We found that tall, urban conifer trees can maintain a unique biodiversity of epiphytic lichen species (Figure 3.1a/b), however these canopy communities contain dramatically different species assemblages of epiphytic lichens, displaying a shift from sensitive, oligotrophic species to a dominance of urbantolerant, eutrophic species (Figure 3.2). More work is needed to better understand how 
the distinct transition of lichen species functional groups in urbanized tree canopies will affect both tree canopy and forest ecosystems, in particular the potential loss of associated ecosystem processes ( $\mathrm{N}$-fixation, hydrologic cycles, etc.) which are largely associated with pristine canopy epiphyte communities in the PNW.

In this study we also observed that canopy-dwelling bryophyte species appear to transition along urban gradients (Table 3.2), but more work is needed to better understand the sensitivities of these species and their use as urban indicators. Contrary to our hypothesis that canopy epiphyte community shifts would result in microarthropod community shifts, surprisingly little impact was seen on the associated microarthropod communities extracted from canopy dwelling assemblages of lichens and bryophytes across the regional gradient (Figures 3.6a/b). Our results show some of the first evidence that tall tree canopies can be impacted by urban metal deposition and also serve important roles in the interception of atmospherically deposited macronutrients (N \& S) in urban forests, as canopy collected lichen thalli showed twice the elemental concentrations of macronutrients than matched ground-based collections in urban sites (Figure 3.4). We provide a discussion of two important ecological implications of our results for PNW forest ecosystems: 1) canopy epiphyte $\mathrm{N}$ fixation and 2) canopy epiphyte microclimate regulation. Lastly, we discuss the potential benefits of tall tree canopy ecosystems in rapidly urbanizing forest areas.

\section{Urban-influenced lichen community shifts in P. menziesii canopies}

The heterogeneity of the urban environment can create positive impacts on biota, resulting in measures of high biodiversity for plant species (Kowarik 2011, Guénard et al. 
2014, Nielsen et al. 2014, Pinho et al. 2016). Our work showed that tall urban conifer trees can contribute to this heterogeneity and to lichen biodiversity by providing a large, stratified habitat (Figures 3.1a \& 3.1b). This study revealed relatively moderate measures of lichen species richness and biodiversity, in ground-based sites along the site gradient, showing the importance of urban-forested areas as suitable habitats and a valuable component of maintaining biodiversity in urban environments.

We observed reduced species richness and biodiversity in canopy-based surveys in this study, which we in part predicted as ground-based surveys plots contain a larger number of microsites and substrate heterogeneity for lichen species than that of a single large conifer tree canopy. We also recognize that it takes time for lichen and bryophyte communities to colonize and establish in tree canopies, and that many lichen species are known as poor dispersers (Sillett et al. 2000b). We hypothesize that the history of repeated forest harvest in the PNW region has impacted the ability of lichens to disperse from remote forest areas to urban forests and may be a factor in the observed paucity of certain lichen species from tall urban conifer tree canopies. We suggest further studies to address the ecological complexities of epiphyte community assembly in urban forest ecosystems.

Our results showed that urban conifer canopies are highly eutrophied (Figure 3.2). Eutrophic lichens are known to respond to multiple forms of $\mathrm{N}$ and dramatic shifts towards a predominantly eutrophic lichen community are used as an indicator of ecosystem "harm" (Jovan et al. 2012). Atmospheric N deposition affects biotic communities and nutrient cycling in forested ecosystems and it is a growing concern in the PNW region, where increasing urbanization and the associated transportation growth 
are the most prevalent factors influencing increasing $\mathrm{N}$ deposition (Fenn et al. 2003b, 2013) Next, we discuss the ecological implications of a eutrophied canopy epiphyte community.

\section{Implications for canopy epiphyte $N$-fixation}

Canopy-dwelling cyanolichens have been renowned for their ability to fix atmospheric $\mathrm{N}_{2}$, making otherwise inaccessible $\mathrm{N}$ available to other forest ecosystem components, an ecologically critical process in the $\mathrm{N}$ limited forests of the PNW region (Denison 1979, Antoine 2004b). This single contribution has established cyanolichens as essential components of forest ecosystem processes (Denison 1979, Sollins et al. 1980, Millbank JW 1982, Antoine 2004) and has further identified them as indicators of 'healthy' forest ecosystems (Campbell and Fredeen 2004, Geiser and Neitlich 2007, Jovan 2008). Our findings suggest that canopy-based N fixation may be the ecological process most affected by urban-induced shifts in lichen community structure, a result of a dramatic shift from sensitive, oligotrophic species to primarily urban-tolerant, eutrophic lichen species in urban conifer tree canopies (Figure 3.2). We documented a complete absence of two iconic PNW cyanolichen species, Lobaria pulmonaria and Lobaria oregana, from tall urban conifer canopies (Table 3.1). Additionally, species of canopydwelling bryophytes that contribute to canopy-based epiphytic $\mathrm{N}$ fixation (Lindo and Whiteley 2011) were also absent from the urban tree canopies.

Canopy-dwelling cyanolichens are particularly vulnerable to human activities and their global decline has been raised as an issue of concern (Goward and Arsenault 2000). Many researchers have worked to quantify canopy-dwelling biomass of L. pulmonaria 
and L. oregana in remote PNW forest ecosystems (McCune 1993, 1994, Peck and McCune 1997, Clement and Shaw 1999, Berryman and McCune 2006, Botting et al. 2008) to establish its ecological significance, yet little has been done to understand how the fundamental absence of these two predominant cyanolichens species in urbanizing forests will affect canopy-based $\mathrm{N}$ fixation and PNW forest ecosystems processes.

Many ecological questions also remain as to the absence of cyanolichens in urban environments. Can the absence of Lobaria sp. be related solely to abiotic urban conditions (i.e. urban heat island temperature effects, excess nutrient and metal deposition)? Or perhaps are urban forest lichen communities controlled by a larger set of ever-changing intrinsic and extrinsic ecological principles regarding community formation. Sillett et al. (2000) found evidence that patterns of forest harvest and removal of old trees are a factor limiting the colonization and dispersal ability of L. oregana from nearby forest patches, and that the subject species was capable of tolerating a wider ecological niche than previously known. Both L. pulmonaria and L. oregana have been thought to require high moisture and low light environments, which has become a generalized view of the entire functional group of cyanolichens. These abiotic sensitivities have been thought to limit their establishment in younger, or urbanized, forests that don't structurally create the shaded and moist microclimates of large, older canopy trees. More recently, it has become clear that the light and moisture requirements of tripartite cephalolichens (L. pulmonaria and L. oregana), which contain both a green algal photobiont and cyanobacteria in specialized cephalodia structures, differ remarkably from other cyanolichen species (whose primary photobiont is a cyanobacteria), resulting in a broader ecological tolerance to light and drying cycles than previously thought 
(Sillett et al. 2000b, Goward 2010, Gauslaa and Coxson 2011, Gauslaa et al. 2012). We hypothesize, along with other prominent studies (Sillett et al. 2000b), that L. pulmonaria and $L$. oregana colonization in urban forests is not limited by niche requirement (light, relative humidity, temperature) but rather by dispersal limitations from propagule sources in remote forests. (See Appendix B for further work)

\section{Implications for canopy microclimate}

Canopy epiphytes buffer canopy microclimates and lower rates of tree evapotranspiration (Freiberg 2001, Stuntz et al. 2002, Prescott 2002, Stanton et al. 2014), creating indirect benefits for plant hosts. Additionally, canopy-dwelling lichens and bryophytes have been shown to increase canopy water storage in tall P. menziesii canopies (Pypker et al. 2006), which have been estimated to hold 1870 and $780 \mathrm{~kg} \mathrm{ha}^{-1}$ (dry mass) of epiphytic lichens and bryophytes (McCune 1993). In this study, we show an absence of large, oligotrophic pendulous and foliose lichen species in urban conifer canopies, as well as a paucity of large biomass bryophyte species (Table $3.1 \& 3.2$ ). Our in situ canopy surveys revealed many species, particularly of Usnea sp. and Platismatia $s p$., that were stunted and compact, a common sign of urban-affected lichen thalli resulting from the toxicity of urban air pollutants (Grenon 2012). Because large lichens store more water per thalli area than small lichens (Merinero et al. 2014), we hypothesize that the replacement and loss of large biomass (both large pendulous and large foliose species) oligotrophic lichen species with tiny, minute eutrophic lichen species and stunted pollution morphs in urbanized tree canopies may hold negative impacts on canopy water storage capacity and microclimate regulation in tall, urban conifer trees. 
The reduction of canopy-held epiphytic biomass, coupled with possible selection for more compact, eutrophic lichen species in urban environments, may be the most influential effect of urbanization on native conifer tree canopies, particularly as we consider the importance of canopy epiphytes to buffer canopy microclimates and lower rates of tree evapotranspiration (Freiberg 2001, Stuntz et al. 2002, Stanton et al. 2014). These shifts may result in profound effects on the resiliency of native conifer trees to buffer themselves in an increasing urbanizing and warming world.

\section{Benefits of epiphyte nutrient and metal sequestration}

Canopy epiphytes serve important roles in forest ecosystem dynamics because of their ability to capture and retain metals and nutrients from atmospheric sources and transfer those nutrients to other ecosystem components (Coxson and Nadkarni 1995, Knops et al. 1996, Tejo et al. 2015). In the PNW a number of studies have cited the phenomenon of tree canopy interception of atmospherically deposited nutrients (Klopatek et al. 2006, Fenn et al. 2013) and in the case of urban atmospheric N pollution, an uncertain amount as much as $20-40 \%$ of atmospheric reactive $\mathrm{N}$ has been estimated to be retained by the canopy. While the exact mechanism for this phenomenon is not known, many hypotheses exist regarding the mechanism for canopy retention of atmospherically deposited $\mathrm{N}$ and $\mathrm{S}$ (i.e foliar uptake, bark absorption, microbial assimilation, and uptake by epiphytic lichens and bryophytes). In this study, we offer evidence that canopy dwelling lichens in tall urban trees (trees $>60 \mathrm{~m}, \&$ mean crown depth $30 \mathrm{~m}$ ) contribute to atmospheric interception of atmospheric $\mathrm{N}$ and $\mathrm{S}$ (Figure 3.4). We found that lichens affixed in urban tall tree canopies intercept atmospheric $\mathrm{N}$ and $\mathrm{S}$ and show two-fold 
higher concentrations (\%) than lichen tissues collected in matched ground-based collections. This study is the first that we know of documenting elemental concentrations of lichens collected in situ, across the vertical gradient of a large conifer tree canopies. We suspected that ground-based collected made from litterfall and branch fall may have lower macronutrient concentrations than those affixed in the canopy because these nutrients are fairly mobile, and can leach or mobilize from thalli quickly when in contact with other substrates, which may underestimate lichen tissues concentrations (\%) from sites which occur along distinct urbanization gradients.

We measured significant changes in the $\mathrm{C}: \mathrm{N}$ ratio in lichen tissues collected across the regional gradient (Figure 3.5), decreasing sharply near the urban environment. We suggest that there may be further potential to use lichen $\mathrm{C}: \mathrm{N}$ ratio across gradients of urbanization as an early sign indication of $\mathrm{N}$ stress in the PNW, as also suggested by Munzi et al. (2013).

We found concentrations of As and $\mathrm{Cu}$ in urban canopy lichen tissues, which exceeded threshold values for clean sites, suggesting that urban canopies are in in fact inundated with deposition of many urban pollutants. Because species-specific tolerances range in response to both nutrient and metal concentrations, more work is needed to understand the complex effects of elevated nutrient and metal deposition on collective epiphyte community colonization and suitability of substrate in urban trees.

The ecological implications of these results are both positive and negative. Elevated metal and nutrient deposition in the urban environment will select and exclude species of canopy epiphytes, as evidenced by the community shifts seen in this study. Elevated deposition of urban pollutants may affect substrate suitability (via changes in 
bark $\mathrm{pH}$, etc.) limiting species establishment and colonization. Biodiversity of the canopy is affects as the urban environment selects for species that can tolerate urban air, excluding many sensitive, endemic species of PNW forests. Additionally, metals can be accumulated in high concentrations in lichen and bryophyte tissues (Bačkor et al. 2010, Donovan et al. 2016) which can effect physiology of the organism and be toxic for invertebrates that use epiphytes as a habitat, however no measure of this were made in this study.

\section{Habitat for canopy-dwelling microarthropods}

Distinct changes in canopy lichen and bryophyte species assemblages were readily observed in this study, yet contrary to our hypothesis that microarthropod communities would track with changing canopy epiphyte species composition, little result was seen on the epiphyte associated microarthropod communities. We acknowledge that a larger sampling effort may better reveal patterns in microarthropod communities along gradients of urbanization. Yet, these results are in agreement with other canopy-based studies which find that suitable habitat availability, such as epiphytic cover (Root et al. 2007) and moisture regimes and relative humidity of microhabitats (Siepel 1996, Lindo and Winchester 2013), may be more important factors controlling canopy-dwelling microarthropod communities than species-specific associations. These conclusions provide evidence that tall, urban conifer trees can provide stratified habitat for many species of lichens and bryophytes, which serve as home for diverse communities of microarthropods that are an important forage source for larger invertebrates and bird species (Pettersson et al. 1995). 


\section{Conclusions}

Overall, we find that tall tree canopy epiphyte communities change dramatically along regional gradients of urbanization, most notably by the transitioning of species $\mathrm{N}$ functional groups from sensitive, oligotrophic species to a dominance of urban-tolerant, eutrophic species, tracking with published results from other PNW regional ground-based studies (Denison, W.C. and Carpenter 1973, Geiser and Neitlich 2007, Root et al. 2015). The implications these dramatic shifts in species composition have on essential PNW ecosystem processes, like $\mathrm{N}$-fixation and canopy microclimate regulation, is still not well understood and difficult to conduct ecosystem-scale projects to formally evaluate. However, we find strong evidence that native conifer trees in urban areas may provide a diversity of essential ecosystem services, including providing stratified habitat for epiphyte communities and their associated microarthropod communities and the scavenging of excess atmospherically deposited nutrients. Future work is needed to understand how losses in canopy $\mathrm{N}$ fixation and species with large biomass (both lichens and bryophytes) will affect nutrient and hydrologic cycling in the PNW region, which continue to undergo rapid growth and urbanization.

\section{Acknowledgements}

We would like to thank the National Science Foundation, Doctoral Dissertation Improvement Grant (no. 1601788, awarded to T. Rosenstiel and H. Prather) and the GK12 Cascades to Coast Fellowship Program (award no. 0948041) for the generous financial support in aid of this project. We also thank M. Amacher, I. Brocker, N. 
Broshot, J. Christy, O. Coleman, M. Duvenek, P. Edwards, K. Fratella, D. Glavich, L. Geiser, J. Groody, L. Holloway, S. Jovan, S. Kiel, E. Leal, K. Petersen-Morgan, Y. Pan and T. Zuniga for project input, help with fieldwork and statistical analyses. 
Table 3.1 Lichen species detected in ground and canopy based surveys $(n=12)$ across a regional urbanization gradient in the Pacific Northwest Region, USA. Asterisks indicate: *species unique to ground-based surveys; ${ }^{* *}$ species unique to canopy-based surveys. Taxa that were pollution morphs or difficult to identify were binned to genus.

\begin{tabular}{|c|c|c|c|c|c|c|c|c|}
\hline & & & $\overline{\mathrm{ROU}}$ & & & ANO & & Total \\
\hline & Scientific Name & Urban & Mid & Remote & Urban & Mid & Remote & Detections \\
\hline$* *$ & Ahtiana sphaerosporella & & & & & & 2 & 2 \\
\hline * & Alectoria imshaugii & & & 1 & & & & 1 \\
\hline & Alectoria sarmentosa & & 3 & 3 & & 8 & 7 & 21 \\
\hline & Bryoria capillaris & & 3 & & & 6 & 4 & 13 \\
\hline & Bryoria fremontii & & & 3 & & 2 & 2 & 7 \\
\hline * & Bryoria friabilis & & 2 & 3 & & & & 5 \\
\hline ** & Bryoria fuscescens & & & & & & 1 & 1 \\
\hline ** & Bryoria glabra & & & & & & 1 & 1 \\
\hline * & Bryoria pseudofuscescens & & 1 & 1 & & & & 2 \\
\hline & Bryoria sp. & & & & & 5 & 12 & 17 \\
\hline *** & Bryoria fuscescens & & & & & & 1 & 1 \\
\hline & Candelaria pacifica & 3 & & & 8 & & & 11 \\
\hline & Cetraria chlorophylla & & 3 & 3 & 3 & 9 & 8 & 26 \\
\hline & Cetraria orbata & & 2 & 2 & & & 3 & 7 \\
\hline * & Cetraria pallidula & & & 1 & & & & 1 \\
\hline & Cetraria platyphylla & & 1 & 3 & & & 1 & 5 \\
\hline & Cladonia carneola & & 1 & & & 1 & 1 & 3 \\
\hline & Cladonia chlorophaea & & & 3 & & 1 & 2 & 6 \\
\hline * & Cladonia coniocraea & 1 & 2 & 3 & & & & 6 \\
\hline * & Cladonia cornuta & & & 1 & & & & 1 \\
\hline * & Cladonia ecmocyna & & & 1 & & & & 1 \\
\hline & Cladonia fimbriata & 1 & & 1 & & 1 & 4 & 7 \\
\hline * & Cladonia furcata & & & 1 & & & & 1 \\
\hline ** & Cladonia pyxidata & & & & & & 1 & 1 \\
\hline ** & Cladonia squamosa & & & & & 1 & & 1 \\
\hline & $\begin{array}{l}\text { Cladonia squamosa var. } \\
\text { subsquamosa }\end{array}$ & 3 & 2 & 1 & & 3 & 3 & 12 \\
\hline & Cladonia transcendens & 3 & 2 & 3 & 3 & 6 & 8 & 25 \\
\hline & Cladonia verruculosa & & 1 & & & 1 & 1 & 3 \\
\hline & Evernia prunastri & 3 & 3 & 1 & 8 & 3 & & 18 \\
\hline * & Fuscopannaria pacifica & & & 1 & & & & 1 \\
\hline & Hypogymnia apinnata & 1 & 2 & 3 & & 9 & 9 & 24 \\
\hline ** & Hypogymnia canadensis & & & & & 1 & & 1 \\
\hline & Hуроgymnia enteromorpha & & 3 & 3 & & 4 & 7 & 17 \\
\hline & Hypogymnia imshaugii & & 3 & 2 & & & 1 & 6 \\
\hline & Hypogymnia inactiva & 1 & 3 & 3 & 1 & 8 & 1 & 17 \\
\hline ** & Hypogymnia occidentalis & & & & & 3 & 2 & 5 \\
\hline & Hypogymnia physodes & 3 & 3 & 3 & 7 & 2 & 2 & 20 \\
\hline & Hypogymnia sp. & & & & & 1 & & 1 \\
\hline & Hypogymnia tubulosa & 3 & 3 & & 8 & 3 & & 17 \\
\hline * & Leptogium polycarpum & & & 1 & & & & 1 \\
\hline & Letharia vulpina & 1 & 1 & 1 & & 3 & 4 & 10 \\
\hline & Lobaria oregana & & 2 & 3 & & 4 & 3 & 12 \\
\hline & Lobaria pulmonaria & & 3 & 3 & & 1 & 2 & 9 \\
\hline & Melanelixia fuliginosa & 2 & 1 & & 2 & & & 5 \\
\hline
\end{tabular}




\begin{tabular}{|c|c|c|c|c|c|c|c|c|}
\hline$*$ & Melanelixia glabra & 1 & & & & & & 1 \\
\hline ** & Melanelixia subargentifera & & & & & 1 & & 1 \\
\hline \multirow[t]{3}{*}{ * } & Melanelixia subaurifera & 2 & 2 & & & & & 4 \\
\hline & Melanohalea exasperatula & 2 & & & 3 & & & 5 \\
\hline & $\begin{array}{l}\text { Melanohalea } \\
\text { subelegantula }\end{array}$ & 2 & & & 4 & 1 & & 7 \\
\hline$* *$ & Menegazzia subsimilis & & & & & 1 & & 1 \\
\hline * & Nephroma bellum & & & 1 & & & & 1 \\
\hline$*$ & Nephroma helveticum & & 2 & 3 & & & & 5 \\
\hline$*$ & Nephroma laevigatum & & 3 & & & & & 3 \\
\hline * & Nephroma parile & & & 1 & & & & 1 \\
\hline \multirow[t]{2}{*}{$*$} & Nephroma resupinatum & & 2 & 1 & & & & 3 \\
\hline & Nodobryoria oregana & & 1 & 1 & & & 4 & 6 \\
\hline$*$ & Parmelia hygrophila & 2 & 3 & 1 & 8 & 4 & & 18 \\
\hline \multirow[t]{4}{*}{$*$} & Parmelia pseudosulcata & & 2 & & & & & 2 \\
\hline & Parmelia saxatilis & 2 & 1 & & 2 & 3 & & 8 \\
\hline & Parmelia sulcata & 3 & 3 & 3 & 7 & 5 & 6 & 27 \\
\hline & Parmeliopsis hyperopta & & 2 & 3 & & & 1 & 6 \\
\hline * & Peltigera collina & 2 & 3 & & & & & 5 \\
\hline$*$ & Peltigera neopolydactyla & & & 1 & & & & 1 \\
\hline$*$ & Physcia adscendens & 1 & & & & & & 1 \\
\hline \multirow[t]{4}{*}{$*$} & Physcia aipolia & & 1 & & & & & 1 \\
\hline & Physcia tenella & 3 & & & 6 & & & 9 \\
\hline & Platismatia glauca & 3 & 3 & 3 & 7 & 9 & 9 & 34 \\
\hline & Platismatia herrei & & 1 & 3 & & 3 & 7 & 14 \\
\hline \multirow[t]{3}{*}{$* *$} & Platismatia norvegica & & & & & 2 & 2 & 4 \\
\hline & Platismatia stenophylla & & 3 & 3 & & 7 & 4 & 17 \\
\hline & $\begin{array}{l}\text { Pseudocyphellaria } \\
\text { anomala }\end{array}$ & & 1 & 1 & & & 3 & 5 \\
\hline * & Pseudocyphellaria anthraspis & & & 3 & & & & 3 \\
\hline$*$ & Pseudocyphellaria crocata & & 1 & 1 & & & & 2 \\
\hline$* *$ & Punctelia perreticulata & & & & 1 & & & 1 \\
\hline \multirow[t]{5}{*}{$*$} & Ramalina dilacerata & & 2 & & & & & 2 \\
\hline & Ramalina farinacea & 3 & 3 & & 4 & & & 10 \\
\hline & Ramalina subleptocarpha & 1 & & & 4 & & & 5 \\
\hline & $\begin{array}{l}\text { Sphaerophorus } \\
\text { tuckermanii }\end{array}$ & & 3 & 3 & & 4 & 2 & 12 \\
\hline & Sphaerophorus venerabilis & & & 2 & & 5 & 7 & 14 \\
\hline$*$ & Sticta limbata & & 1 & & & & & 1 \\
\hline \multirow[t]{8}{*}{$*$} & Usnea diplotypus & 2 & & & & & & 2 \\
\hline & Usnea filipendula & & 1 & & & 3 & 1 & 5 \\
\hline & Usnea flavocardia & 2 & 1 & & 4 & & & 7 \\
\hline & Usnea pacificana & & & 2 & & 1 & & 3 \\
\hline & Usnea scabrata & & 3 & 2 & 1 & 6 & 6 & 18 \\
\hline & Usnea scabrata/filipendula grov & & & 1 & & 1 & 1 & 3 \\
\hline & Usnea sp. & 1 & & & 3 & & & 4 \\
\hline & Usnea subfloridana & 1 & 3 & 2 & 3 & & & 9 \\
\hline \multirow[t]{2}{*}{$* *$} & Xanthomendoza fulva & & & & 1 & & & 1 \\
\hline & Xanthoria polycarpa & 1 & & & 5 & & & 6 \\
\hline
\end{tabular}


Table 3.2 Canopy-dwelling bryophyte species detected in canopy-based surveys $(n=12)$ across a regional urbanization gradient in the Pacific Northwest Region, USA.

\begin{tabular}{l|ccccccccccc|c}
\hline & \multicolumn{1}{c}{ URBAN } & \multicolumn{1}{c}{ MID } & \multicolumn{7}{c}{ REMOTE } \\
Scientific Name & top & mid & low & top & mid & low & top & mid & low & Total Detections \\
\hline Antitrichia curtipendula & 0 & 0 & 0 & 1 & 2 & 1 & 0 & 1 & 1 & 6 \\
Dicranoweisia cerrata & 2 & 2 & 3 & 1 & 0 & 0 & 0 & 0 & 0 & 8 \\
Dicranum tauricum & 0 & 0 & 0 & 2 & 1 & 2 & 1 & 3 & 2 & 11 \\
Hypnum circinale & 0 & 0 & 0 & 0 & 1 & 1 & 0 & 0 & 0 & 2 \\
Isothecium cristatum & 0 & 0 & 0 & 0 & 1 & 0 & 0 & 1 & 1 & 3 \\
Isothecium stoloniferum & 0 & 0 & 0 & 0 & 0 & 1 & 0 & 0 & 1 & 2 \\
Porella navicularis & 0 & 0 & 0 & 0 & 1 & 0 & 0 & 0 & 0 & 1 \\
Orthotrichum lyellii & 2 & 2 & 1 & 1 & 1 & 0 & 0 & 0 & 0 & 7 \\
Ulota megalospora & 0 & 0 & 0 & 1 & 0 & 0 & 0 & 0 & 0 & 1
\end{tabular}


Table 3.3 Summary statistics of lichen tissue accumulated metals in ground-based collections of Platismatia glauca across a regional urbanization gradient (urban, mid, remote), expressed as parts per million per dry weight. Values that exceed the P. glauca threshold value (ppm) indicate deposition levels that exceed the established regional threshold value for clean sites. Bold/highlighted values indicated sites where values exceed the regional threshold.

\begin{tabular}{|c|c|c|c|c|c|c|c|c|c|c|}
\hline \multirow{2}{*}{\multicolumn{2}{|c|}{$\begin{array}{l}\text { P. glauca Threshold } \\
\text { Value (ppm) }\end{array}$}} & B & Co & $\mathrm{Cr}$ & $\mathbf{C u}$ & $\mathbf{F e}$ & Mn & $\mathbf{N i}$ & $\mathbf{P b}$ & $\mathbf{Z n}$ \\
\hline & & 3.6 & 0.3 & 3 & 27.8 & 1459 & 803.7 & 4.4 & 10 & 49.6 \\
\hline \multicolumn{11}{|l|}{ Urban } \\
\hline \multirow[t]{5}{*}{ Ground-level } & mean & 5.9 & 0.3 & 9.6 & 469.5 & 313.2 & 22.8 & 6.0 & 27.0 & 63.9 \\
\hline & std dev & 4.9 & 0.3 & 13.5 & 803.3 & 157.0 & 12.0 & 8.6 & 44.3 & 74.0 \\
\hline & std err & 2.8 & 0.2 & 7.8 & 463.8 & 90.6 & 6.9 & 5.0 & 25.6 & 42.7 \\
\hline & $\max$ & 11.5 & 0.6 & 25.2 & 1397.1 & 441.3 & 35.2 & 16.0 & 78.2 & 148.9 \\
\hline & $\min$ & 2.3 & 0.1 & 0.8 & 4.5 & 138.1 & 11.2 & 0.8 & 1.3 & 14.4 \\
\hline \multirow{6}{*}{$\begin{array}{l}\text { Mid } \\
\text { Ground-level }\end{array}$} & & & & & & & & & & \\
\hline & mean & 3.0 & 0.2 & 4.2 & 93.3 & 191.9 & 82.4 & 1.9 & 4.0 & 18.2 \\
\hline & std dev & 0.4 & 0.1 & 5.0 & 151.9 & 9.2 & 34.9 & 2.6 & 6.1 & 13.7 \\
\hline & std err & 0.3 & 0.1 & 2.9 & 87.7 & 5.3 & 20.2 & 1.5 & 3.5 & 7.9 \\
\hline & $\max$ & 3.4 & 0.3 & 10.0 & 268.7 & 199.0 & 108.6 & 5.0 & 11.0 & 34.0 \\
\hline & $\min$ & 2.5 & 0.1 & 1.3 & 5.5 & 181.5 & 42.7 & 0.4 & 0.4 & 9.0 \\
\hline \multirow[t]{5}{*}{$\begin{array}{l}\text { Remote } \\
\text { Ground-level }\end{array}$} & mean & 2.2 & 0.1 & 0.8 & 2.9 & 111.0 & 70.3 & 0.3 & 0.4 & 9.4 \\
\hline & std dev & 0.3 & na & 0.3 & 0.0 & 23.1 & 60.9 & na & 0.0 & 0.4 \\
\hline & std err & 0.2 & na & 0.2 & 0.0 & 13.4 & 35.2 & na & 0.0 & 0.3 \\
\hline & $\max$ & 2.5 & 0.1 & 1.1 & 3.0 & 125.9 & 140.1 & 0.3 & 0.5 & 9.9 \\
\hline & $\min$ & 1.9 & 0.1 & 0.4 & 2.9 & 84.4 & 28.4 & 0.3 & 0.4 & 9.1 \\
\hline
\end{tabular}


Table 3.4 Summary statistics of lichen tissue accumulated metals in stratified canopybased collections of Platismatia glauca across a regional urbanization gradient (urban, mid, remote), expressed as parts per million per dry weight. Values that exceed the $P$. glauca threshold value ( $\mathrm{ppm}$ ) indicate deposition levels that exceed the established regional threshold value for clean sites. Bold/highlighted values indicate sites where values exceed the regional threshold. Regional thresholds values for Arsenic (As) have not been established yet; the range of values $(0.53-0.94 \mathrm{ppm})$ used here are derived from values determined in a Portland area study (Donovan et al. 2016). Canopy stratification is indicated as $\mathrm{T}=$ top canopy, $\mathrm{M}=$ mid canopy, $\mathrm{L}=$ low canopy

\begin{tabular}{|c|c|c|c|c|c|c|c|c|}
\hline & & As & $\mathbf{C u}$ & $\mathbf{F e}$ & Mn & $\mathbf{N i}$ & $\mathbf{P b}$ & V \\
\hline P. glauca Thr & $(\mathbf{p p m})$ & $0.53-0.94$ & 27.8 & 1459 & 803.7 & 4.4 & 10 & 4.6 \\
\hline Urban & mean & 0.4 & 5.8 & 243.1 & 25.0 & 0.5 & 2.5 & 4.4 \\
\hline Low Canopy & std dev & 0.1 & 0.5 & 41.2 & 7.0 & na & 1.5 & 0.1 \\
\hline & std err & 0.1 & 0.3 & 23.8 & 4.0 & na & 0.9 & 0.1 \\
\hline & $\max$ & 0.6 & 6.4 & 273.2 & 33.0 & 0.5 & 4.2 & 4.5 \\
\hline & $\min$ & 0.3 & 5.4 & 196.2 & 20.5 & 0.5 & 1.6 & 4.3 \\
\hline Urban & mean & 0.5 & 31.4 & 287.9 & 27.6 & 0.8 & 2.8 & 4.4 \\
\hline Mid Canopy & std dev & 0.2 & 42.9 & 131.9 & 7.3 & 0.3 & 2.7 & 0.2 \\
\hline & std err & 0.1 & 24.8 & 76.2 & 4.2 & 0.2 & 1.5 & 0.1 \\
\hline & $\max$ & 0.7 & 80.9 & 437.0 & 31.9 & 1.1 & 5.8 & 4.5 \\
\hline & $\min$ & 0.4 & 5.9 & 186.5 & 19.1 & 0.5 & 0.6 & 4.3 \\
\hline Urban & mean & 0.6 & 14.9 & 459.6 & 39.8 & 0.9 & 3.0 & 4.8 \\
\hline Top Canopy & std dev & 0.0 & 0.9 & 39.2 & 1.6 & 0.0 & 0.2 & 0.1 \\
\hline & std err & 0.0 & 0.7 & 27.8 & 1.1 & 0.0 & 0.2 & 0.1 \\
\hline & $\max$ & 0.6 & 15.6 & 487.3 & 40.9 & 1.0 & 3.2 & 4.9 \\
\hline & $\min$ & 0.5 & 14.3 & 431.8 & 38.7 & 0.9 & 2.9 & 4.7 \\
\hline Mid & mean & 0.4 & 4.4 & 194.5 & 89.7 & 0.4 & 0.9 & 4.4 \\
\hline Low Canopy & std dev & 0.1 & 0.6 & 48.7 & 53.0 & 0.2 & 0.5 & 0.1 \\
\hline & std err & 0.0 & 0.4 & 28.1 & 30.6 & 0.1 & 0.3 & 0.1 \\
\hline & $\max$ & 0.4 & 5.1 & 247.1 & 148.7 & 0.5 & 1.4 & 4.5 \\
\hline & $\min$ & 0.3 & 4.0 & 150.9 & 46.3 & 0.2 & 0.5 & 4.3 \\
\hline Mid & mean & 0.4 & 5.5 & 219.3 & 79.9 & 0.6 & 0.8 & 4.5 \\
\hline Mid Canopy & std dev & na & 3.1 & 53.5 & 42.7 & 0.3 & 0.4 & 0.1 \\
\hline & std err & na & 1.8 & 30.9 & 24.7 & 0.2 & 0.3 & 0.1 \\
\hline & $\max$ & 0.4 & 9.0 & 279.3 & 110.5 & 0.9 & 1.3 & 4.7 \\
\hline & $\min$ & 0.4 & 3.6 & 176.5 & 31.1 & 0.3 & 0.5 & 4.4 \\
\hline Mid & mean & 0.4 & 3.9 & 218.9 & 52.5 & 0.6 & 0.9 & 4.4 \\
\hline Top Canopy & std dev & 0.1 & 0.5 & 62.7 & 30.2 & 0.3 & 0.5 & 0.1 \\
\hline & std err & 0.0 & 0.3 & 36.2 & 17.4 & 0.2 & 0.3 & 0.1 \\
\hline & $\max$ & 0.5 & 4.4 & 275.2 & 86.1 & 0.9 & 1.5 & 4.6 \\
\hline & $\min$ & 0.3 & 3.5 & 151.3 & 27.7 & 0.3 & 0.6 & 4.3 \\
\hline
\end{tabular}




\begin{tabular}{lrrrrrrrr}
\hline Remote & mean & 0.3 & 3.3 & 149.1 & 71.7 & 0.4 & 0.7 & 4.3 \\
Low Canopy & std dev & 0.1 & 0.3 & 55.7 & 46.6 & 0.2 & 0.4 & 0.1 \\
& std err & 0.0 & 0.2 & 32.1 & 26.9 & 0.1 & 0.3 & 0.1 \\
& $\max$ & 0.4 & 3.7 & 205.9 & 122.1 & 0.7 & 1.0 & 4.5 \\
& min & 0.3 & 3.1 & 94.7 & 30.3 & 0.3 & 0.4 & 4.2 \\
\hline Remote & mean & 0.3 & 3.2 & 172.1 & 60.7 & 0.5 & 0.5 & 4.4 \\
Mid Canopy & std dev & 0.1 & 0.2 & 29.6 & 31.3 & 0.2 & 0.1 & 0.1 \\
& std err & 0.0 & 0.1 & 17.1 & 18.1 & 0.1 & 0.1 & 0.0 \\
& max & 0.4 & 3.4 & 202.3 & 95.3 & 0.7 & 0.6 & 4.4 \\
Remote & min & 0.3 & 3.1 & 143.1 & 34.2 & 0.3 & 0.5 & 4.3 \\
Top Canopy & mean & 0.3 & 3.5 & 185.9 & 48.0 & 0.5 & 0.5 & 4.4 \\
& std dev & na & 0.9 & 18.4 & 21.4 & 0.2 & 0.1 & 0.0 \\
& std err & na & 0.5 & 10.6 & 12.4 & 0.1 & 0.1 & 0.0 \\
& max & 0.3 & 4.6 & 197.9 & 72.7 & 0.8 & 0.6 & 4.5 \\
& min & 0.3 & 2.9 & 164.7 & 35.5 & 0.4 & 0.4 & 4.4 \\
\hline
\end{tabular}


Table 3.5 Summary statistics of lichen tissue accumulated metals in ground-based collections of Platismatia glauca across a regional urbanization gradient (urban, mid, remote). Values shown are log-transformed parts per million concentration values per dry weight of tissue. Significantly higher accumulation occurred in urban sites; level of significance is indicated by letters $(\mathrm{p}=0.05, n=3)$ and asterisks $(\mathrm{p}=0.01 n=3)$.

\begin{tabular}{ccccccc|cccccc} 
& \multicolumn{4}{c}{ Urban Ground-Level } & \multicolumn{1}{c}{ Mid Ground-Level } \\
\cline { 2 - 13 } & $\mathrm{n}$ & mean & sd & se & min & max & n & mean & sd & se & min & max \\
\hline Mn (ppm) & 3 & $3.03 *$ & 0.57 & 0.33 & 2.42 & 3.56 & 3 & $4.33^{* *}$ & 0.51 & 0.29 & 3.75 & 4.69 \\
Pb (ppm) & 2 & 0.38 a & na & na & 0.28 & 0.48 & 2 & $-0.77 \mathbf{b}$ & na & na & -0.87 & -0.67 \\
\hline
\end{tabular}

\section{Urban Ground-Level}

Remote Ground-Level

\begin{tabular}{|c|c|c|c|c|c|c|c|c|c|c|c|c|}
\hline & $\bar{n}$ & mean & sd & $\mathrm{se}$ & $\min$ & $\max$ & $\bar{n}$ & mean & $\mathrm{sd}$ & se & $\min$ & $\max$ \\
\hline Mn (ppm) & 3 & $3.03 \mathrm{a}$ & 0.57 & 0.33 & 2.42 & 3.56 & 3 & $4.01 \mathrm{~b}$ & 0.83 & 0.48 & 3.35 & 4.94 \\
\hline $\mathrm{Fe}(p p m)$ & 3 & $5.64 \mathbf{a}$ & 0.62 & 0.36 & 4.93 & 6.09 & 3 & $4.69 \mathrm{~b}$ & 0.23 & 0.13 & 4.43 & 4.84 \\
\hline Ni (ppm) & 2 & $0.02 \mathbf{a}$ & na & na & -0.22 & 0.26 & 2 & $-1.19 \mathbf{b}$ & na & na & -1.24 & -1.14 \\
\hline Pb (ppm) & 2 & $0.38 *$ & na & na & 0.28 & 0.48 & 3 & $-0.91 * *$ & 0.11 & 0.06 & -0.97 & -0.78 \\
\hline
\end{tabular}


Figure 3.1 a) Mean ( \pm SE) lichen species richness and biodiversity across a regional gradient of urbanization. a) Lichen species richness was significantly lower in urban sites $(\mathrm{p}=0.001, n=3)$ and was affected by stratification $(\mathrm{p}=0.001, n=9)$, revealing significant differences between ground and canopy richness in mid and remote sites $(\mathrm{p}=0.02, n=9)$ and distinctly similar patterns of richness between urban canopies and matched ground level surveys $(\mathrm{p}=0.02, n=9)$. b) Mean $( \pm \mathrm{SE})$ lichen biodiversity was found to be significantly lower in urban sites $(\mathrm{p}=0.001, n=3)$; biodiversity was highest in ground based surveys at mid and remote locations $(\mathrm{p}=0.001, n=9)$ and lowest in the top canopy of the urban trees surveyed $(\mathrm{p}=0.001, n=9)$, as indicated by the Shannon Diversity Index. Canopy stratification is indicated as $\mathrm{G}=$ ground, $\mathrm{T}=$ top canopy, $\mathrm{M}=$ mid canopy, $\mathrm{L}=$ low canopy.
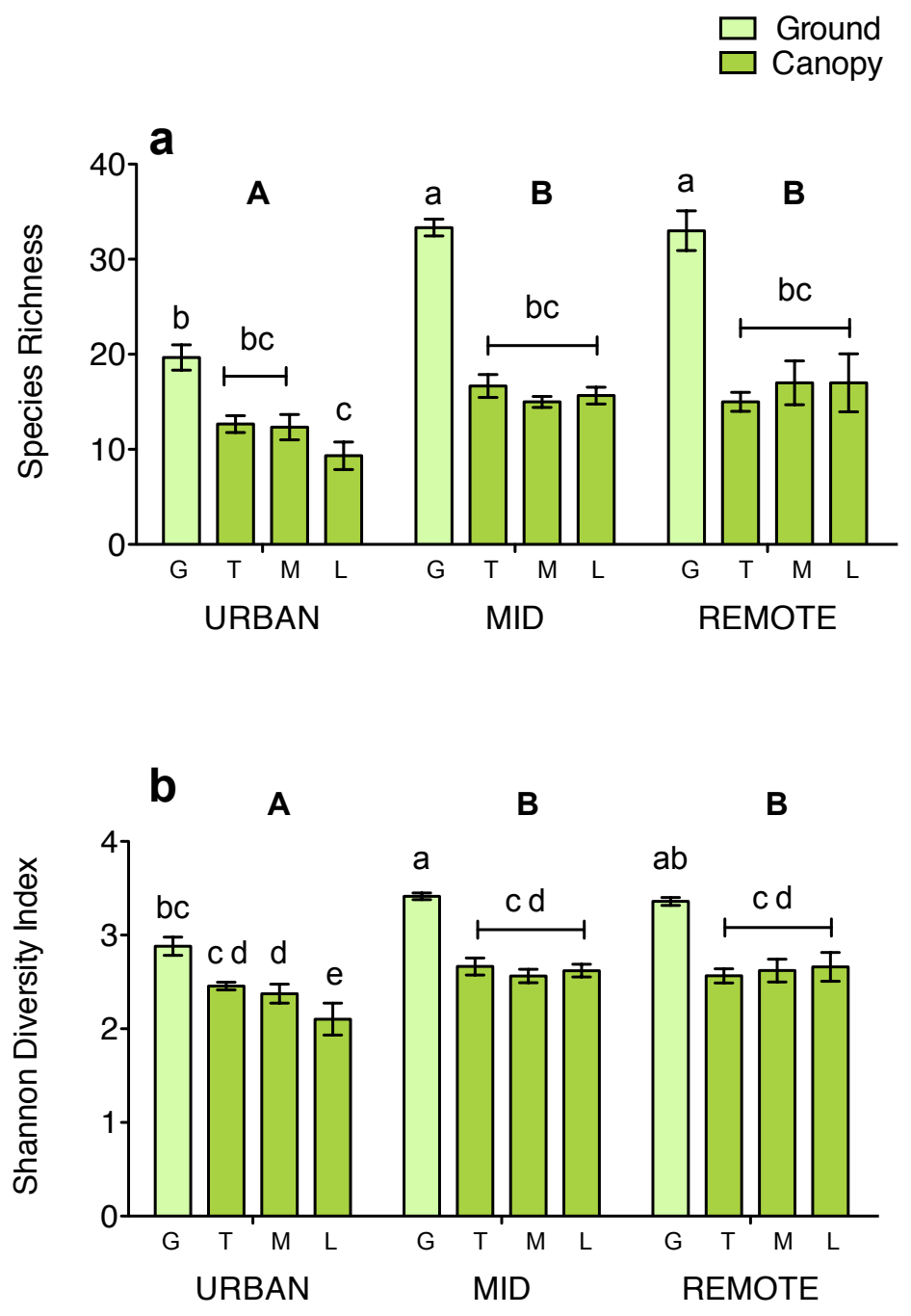
Figure 3.2 Mean $( \pm \mathrm{SE})$ relative frequency of ground and canopy dwelling epiphytic lichen species across a regional urbanization gradient reveals dramatic shifts in lichen community composition in both urban sites and at all layers of canopy stratification in tall tree canopies. Lichen species are categorized by functional $\mathrm{N}$ rating: eutroph or nitrophilous $\left(>4.6 \mathrm{~kg} \mathrm{~N}^{-} \mathrm{ha}^{-1} / \mathrm{yr}^{-1}\right)$, mesotroph $\left(2.5-4.5 \mathrm{~kg} \mathrm{~N}^{-} / \mathrm{ha}^{-1} / \mathrm{yr}^{-1}\right)$, or oligotroph $(<2.4$ $\left.\mathrm{kg} \mathrm{N} / \mathrm{ha}^{-1} / \mathrm{yr}^{-1}\right)$. Bold line indicates $>35 \%$ proportion of eutrophic species, signifying elevated ecosystem $\mathrm{N}$ inputs. Canopy stratification is indicated as $\mathrm{G}=$ ground, $\mathrm{T}=$ top canopy, $\mathrm{M}=$ mid canopy, $\mathrm{L}=$ low canopy.

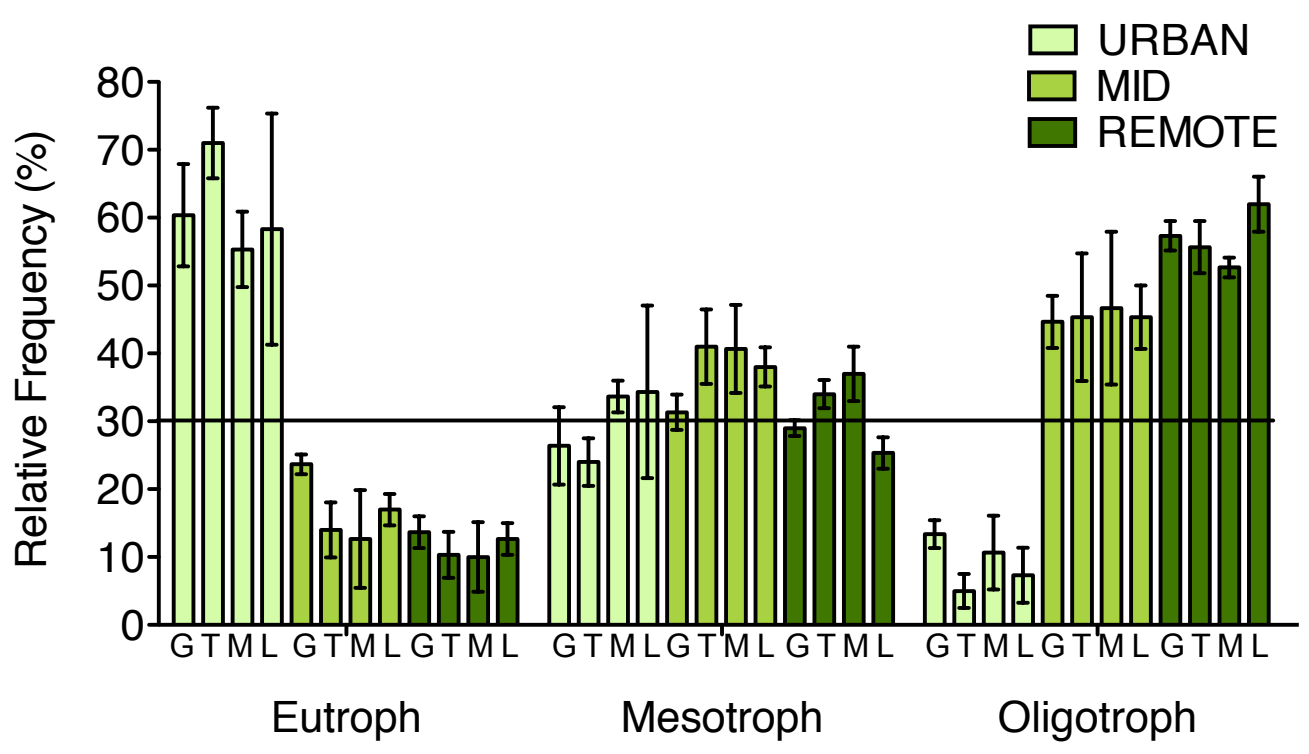


Figure 3.3 Mean $( \pm \mathrm{SE})$ air scores for ground and canopy lichen surveys, derived from regional plot scores on lichen community gradients using non-metric multidimensional scaling ordination. Significant differences $(\mathrm{p}=0.001, n=3)$ between ground AQ scores and canopy AQ scores occurred in the mid site location. Positive air scores indicate the most polluted sites on the regional gradient.

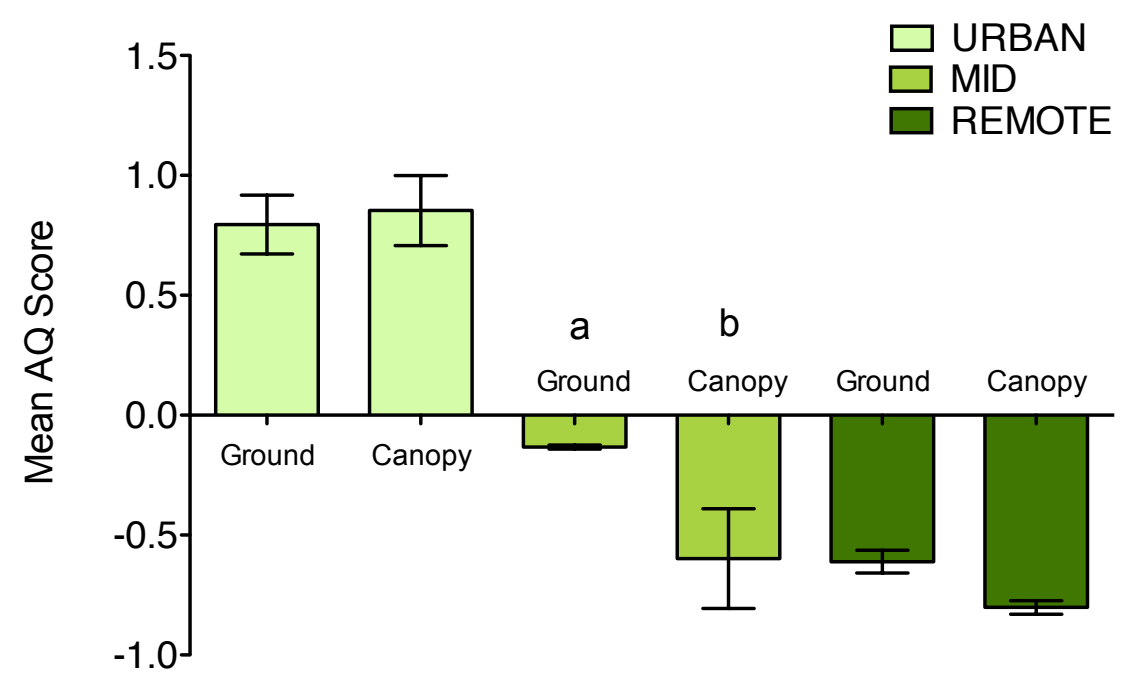


Figure 3.4 Mean $( \pm \mathrm{SE})$ combustion analyzed N \& S (Leco 502-277) from P. glauca and $P$. sulcata tissue collections exceeds threshold values for clean site values. Urban canopy collections are significantly higher in $\mathrm{N} \& \mathrm{~S}(\%)$ than urban ground-based collections (Nitrogen: $\mathrm{p}=0.001, n=3$; Sulfur: $\mathrm{p}=0.001, n=3$ ). Canopy stratification is indicated as $\mathrm{G}=$ ground, $\mathrm{T}=$ top canopy, $\mathrm{M}=$ mid canopy, $\mathrm{L}=$ low canopy. Canopy stratification is indicated as $\mathrm{G}=$ ground, $\mathrm{T}=$ top canopy, $\mathrm{M}=$ mid canopy, $\mathrm{L}=$ low canopy.
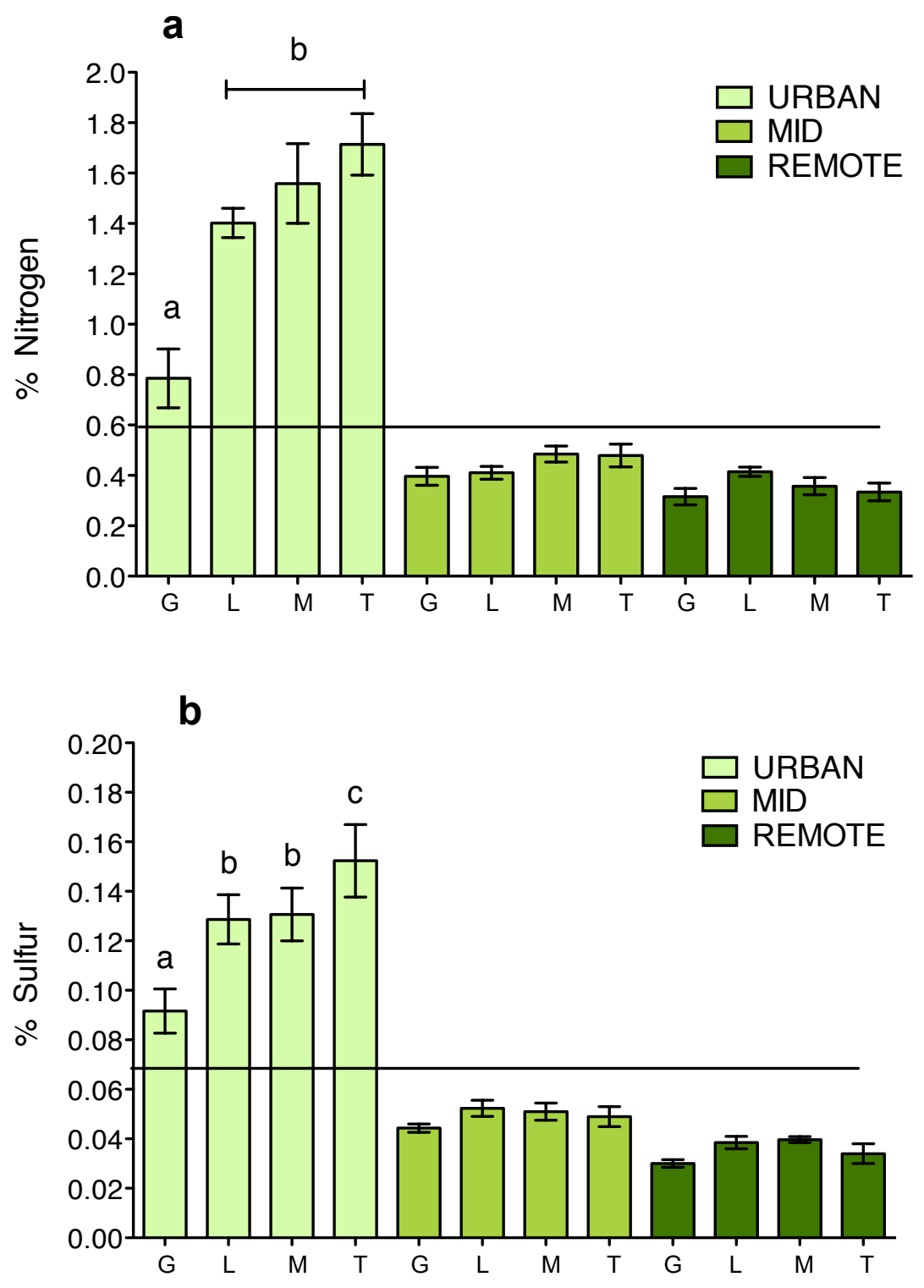
Figure 3.5 Mean $( \pm \mathrm{SE}) P$. glauca and $P$. sulcata $\mathrm{C}: \mathrm{N}$ ratio of pooled ground and canopy collected lichen tissues, $\mathrm{C}: \mathrm{N}$ ratio differed significantly across the regional urbanization site gradient $(\mathrm{p}=0.001, n=15)$.

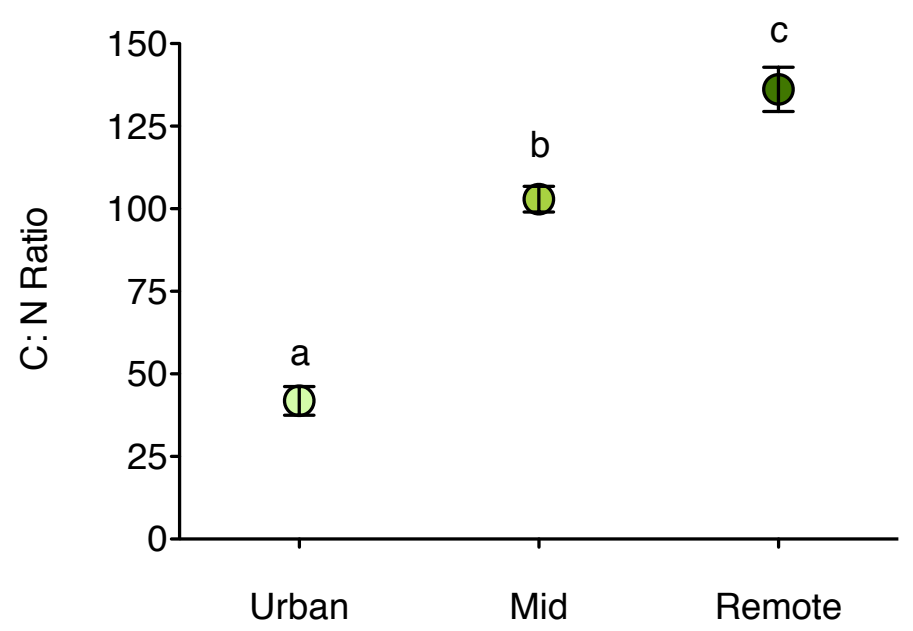


Figure 3.6 a) Mean $( \pm \mathrm{SE})$ number of microarthropods per g/DW extracted from canopydwelling assemblages of epiphytic lichens and bryophytes across a regional gradient of urbanization (urban, mid, remote) in the Pacific Northwest Region, USA. b) Mean $( \pm$ SE) relative frequency of microarthropod communities as extracted from canopy-dwelling lichen and bryophyte assemblages. No significant differences were seen in canopydwelling microarthropod communities in $P$. menziesii across the site gradient (a) $\mathrm{p}=0.81$, $n=12$; b) $\mathrm{p}=0.44, n=12$ ).
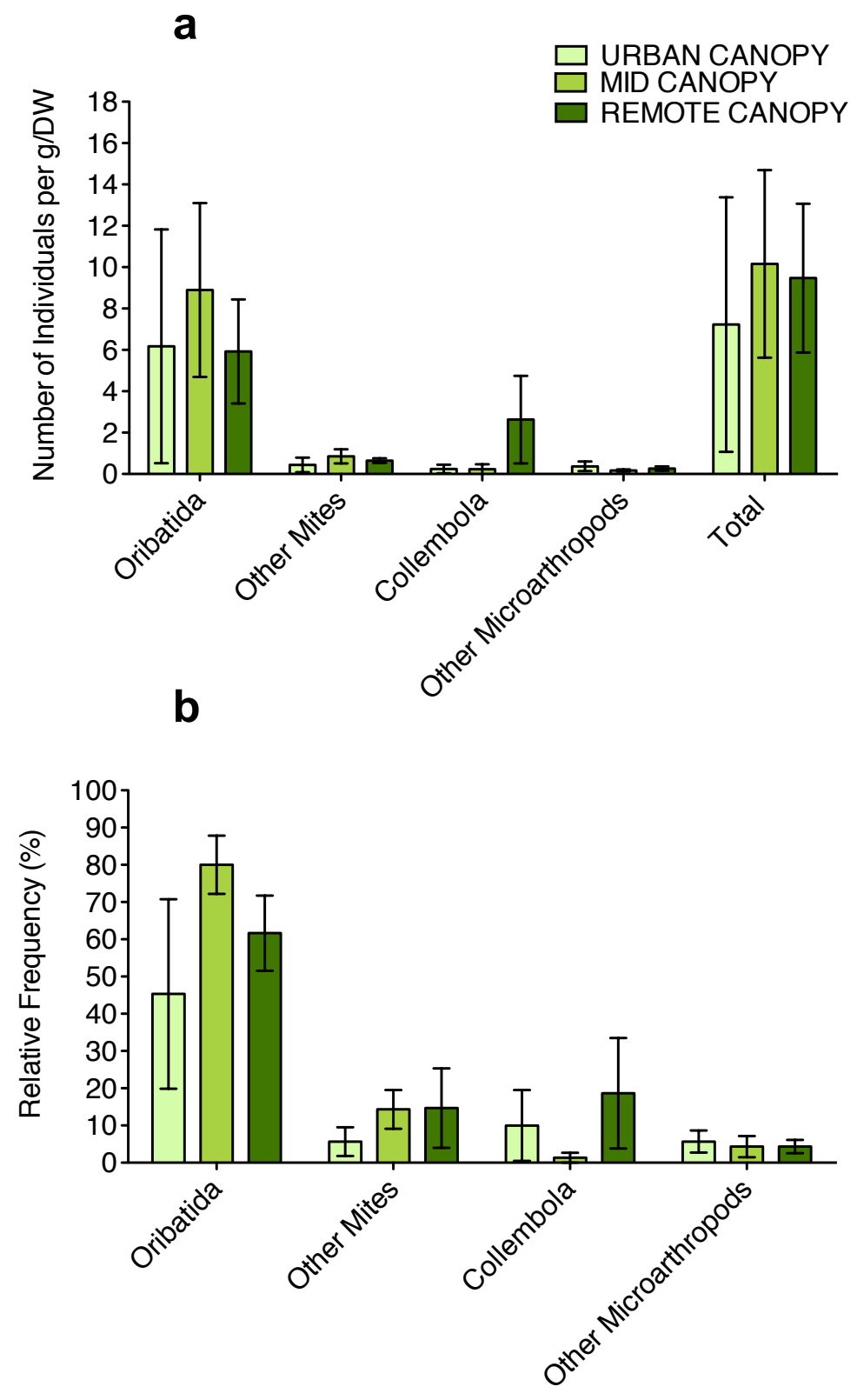


\title{
Chapter 4
}

\section{Species-specific effects of passive warming in an Antarctic moss system on King George Island, Antarctica}

\begin{abstract}
Arctic and Antarctic ecosystems are experiencing rapid climate change and because Polar ecosystems are highly sensitive to change, the impacts will be pronounced in these regions. The western Antarctic Peninsula is one of the fastest warming regions on Earth, resulting in a mosaic of ice-free terrestrial habitats. The ice-free areas of the Antarctic Peninsula are dominated by cryptogamic flora, particularly a diverse assemblage of bryophytes ( $>100$ species). Mosses provide habitat for a diversity of microorganisms and invertebrates, forming complex food webs that regulate organic matter decomposition, carbon sequestration and nutrient cycling. Further, the presence of dense moss mats provides a high-level of soil thermal insulation, further highlighting the important role of mosses in linking above- and below-ground ecosystem processes in Polar regions. In this research we investigated the impacts of passive warming by Open Top Chambers (OTCs) in moss-dominated ecosystems on Fildes Peninsula, King George Island, Antarctica, a region of increased climate warming. We compared species-specific temperature effects, moss canopy morphology, sexual reproductive effort and invertebrate communities between OTC and control moss communities for two moss species, Polytrichastrum alpinum and Sanionia uncinata, that make up over $65 \%$ of the terrestrial vegetative cover in the area. We found distinct reproductive shifts in $P$. alpinum under passive warming compared to those without warming. Moss communities under warming also had substantially larger total invertebrate communities than those in control moss
\end{abstract}


communities, and invertebrate communities were significantly affected by moss species and moss reproductive effort. We further observed substantial species-specific thermal differences among contiguous patches of these dominant moss species. Our results suggest that continued warming will differentially impact the reproductive output of Antarctic moss species and is likely to dramatically alter terrestrial ecosystems dynamics from the bottom up, understanding these effects will require clarifying the foundational mechanistic roles that individual moss species play in mediating complex interactions in Antarctica's terrestrial food-webs.

\section{Introduction}

Arctic and Antarctic ecosystems are experiencing rapid climate change, which holds implications for terrestrial polar ecosystems (Post et al. 2009, Turner et al. 2014). Global circulation models predict that twenty-first century climate changes will be greatest both in terms of magnitude and speed of response in the polar regions (ACIA 2005, Turner et al. 2014). Polar ecosystems are highly sensitive to climate changes (Convey and Smith 2006, Parmesan 2006, Wall 2007, Elmendorf et al. 2012, Turner et al. 2014), and the impacts will be pronounced in these regions (Millennium Ecosystem Assessment 2005, Turner et al. 2014). The Western Antarctic Peninsula and the Scotia Arc region of the Southern Ocean are among the fastest warming regions on Earth (Convey et al. 2009, Turner et al. 2014). Records show a $0.2^{\circ} \mathrm{C}$ increase per decade since the 1950's in the Scotia Arc region and an even greater increase of $0.54^{\circ} \mathrm{C}$ per decade recorded at the Faraday/Vernadsky Station on the western side of the Antarctic Peninsula (maritime Antarctica) (Turner et al. 2014). Temperature increases have been highest in 
the winter along the western Antarctic Peninsula, while summer warming has been greatest along the eastern Antarctic Peninsula. While the warming trends on the Antarctic Peninsula are supported by a 50 year record (Turner et al. 2014), long term precipitation data are hard to obtain as in situ measurements are difficult. Climate models predict increasing precipitation throughout Antarctica regions over the next century. Consequently, there has been changes in soil water availability based on the increase in precipitation as well as from glacier melt, particularly during the Antarctic summer. Biodiversity in Antarctica is strongly driven by patterns of water availability (Convey et al. 2014), and the increase in water availability with climate changes will likely alter patterns of diversity and expose new potential habitats to be colonized by terrestrial biota, particularly pioneer species such as lichens and bryophytes (Convey and Smith 2006, Convey et al. 2009).

Antarctica is mostly ice covered; of its 14 million $\mathrm{km}^{2}$ surface area, only about 0.34\% remains seasonally ice and snow free (Ugolini and Bockheim 2008). Most of the ice-free areas are small and 'island-like,' leading to diversity of terrestrial ecosystems (Convey 2011). Despite rapid warming, Antarctica remains one of the harshest environments on Earth, with relatively few terrestrial organisms able to survive on its icefree terrain (Kappen 1993). Antarctic vegetation is dominated by a cryptogamic flora, with numerous species of lichens ( $>200$ species) and bryophytes ( $>100$ species) (Ochyra 1998, Chown et al. 2015). Many terrestrial invertebrate groups are also represented, including tardigrades, nematodes, springtails and mites (Velasco-Castrillón et al. 2014, Chown et al. 2015). Given the severe constraints of climate, dispersal and habitable land surface area in Antarctica, an amelioration of any of these factors may have 
disproportionally large impacts on Antarctic terrestrial ecosystems (Nielsen and Wall 2013).

Bryophytes, including mosses, are a dominant terrestrial vegetation in Antarctica, particularly on the western Antarctic peninsula where they are the predominate land cover of the available terrestrial habitats. Mosses and their associated microfauna, serve fundamentally important roles in ecosystem functioning worldwide, contributing to the production of aboveground biomass (Cornelissen et al. 2007, Wardle et al. 2012), regulation of abiotic conditions such as soil temperature and moisture (Longton 1997), and are important drivers of ecosystem biogeochemical cycles (DeLuca et al. 2002, Turetsky 2003, Lagerström et al. 2007). Mosses also provide habitat for a diversity of microorganisms and invertebrates that form complex food webs which regulate organic matter decomposition, carbon sequestration and nutrient cycling, providing an essential link between above- and belowground ecosystem components (see 'the bryosphere', Lindo and Gonzalez 2010, Wardle et al. 2012). In polar ecosystems specifically, accumulating bryophyte biomass (land cover) provides high thermal insulation, waterholding and cation exchange capacities. Therefore, bryophyte cover in polar ecosystems exerts a strong influence on soil temperature, water regimes, nutrient cycling and provides a significant carbon sink in terms of global warming (Longton 1997, Stoy et al. 2012, Soudzilovskaia et al. 2013, Fisher et al. 2016).

Little is known about the response of Antarctic mosses and their associated communities of microorganisms and invertebrates to climate change (Robinson et al. 2003), yet the abundance and productivity of mosses will undoubtedly be influenced by coupled changes in temperature and precipitation in Antarctica, largely because mosses 
are pokilohydric organisms which rely directly on the environment for water and lack mechanisms to prevent desiccation making them particularly sensitive to changes in climate and precipitation regimes at both micro- and macro- levels (He et al. 2016). Additionally, moss species-specific functional traits can vary greatly; therefore, speciesspecific responses would be anticipated with climate warming, yet are often overlooked as bryophytes are often lumped together as a single functional group in Antarctic studies. Yet, increasing climate warming on the western Antarctic peninsula is anticipated to encourage the growth and spreading of moss vegetation in Antarctica, which will further influence terrestrial ecosystem succession (Turetsky 2003, Convey et al. 2009) and hold implications for the microorganism and invertebrate communities they sustain (Convey et al. 2009). Moreover, few studies on Antarctica mosses have examined the effects of warming on sexual reproduction (Casanova-Katny et al. 2016, Shortlidge et al. 2016) which is key to understanding dynamics of developing moss communities, and to our knowledge, no studies to date have examined both reproductive output and associated invertebrate communities of the dominant moss species, despite the important ecological connection of invertebrates and moss fertilization (Cronberg et al. 2006, Rosenstiel et al. 2012). Given the magnitude of terrestrial vegetative cover comprised of mosses in maritime Antarctica, the study of species-specific moss responses to warming is critical to better provide insight into specific organism's responses to warming and the links to larger ecosystem processes of terrestrialization in Antarctica.

Here, we used a passive warming experiment to examine how temperature change affects moss morphology and sexual expression and whether correlated changes also occurred in associated invertebrate communities. Open Top Chambers (OTCs) and 
control plots had been established for eight years at Juan Carlos Point on Fildes Peninsula, located in maritime Antarctica on King George Island (KGI). In the experiment, we examined vegetative species cover, and collected cores of the two dominant bryophyte species, Sanionia uncinata and Polytrichastrum alpinum, which comprise $65 \%$ of the terrestrial vegetative cover in the area. Using these cores, we tested the effects of the experimental temperature treatment on moss canopy morphology, reproductive effort and invertebrate communities. We predicted that passive warming would differentially impact moss species and that these differences would scale up to invertebrate communities.

\section{Materials and Methods}

\section{Study area}

Our study site was located on Fildes Peninsula, King George Island $\left(62^{\circ} 00^{\prime} \mathrm{S}, 58^{\circ}\right.$ $\left.15^{\prime} \mathrm{W}\right)$, in the South Shetland Island Archipelago, one of the largest ice-free areas in the Antarctica Peninsula (Ochyra 1998). King George Island is known for its rich bryophyte flora, containing 61 unique bryophyte species, of which 40 have been recorded on Fildes Peninsula alone (Ochyra 1998). The experiments were carried out at Juan Carlos Point $\left(62^{\circ} 12^{\prime} \mathrm{S}, 58^{\circ} 59^{\prime} \mathrm{W}\right)$, which is characterized by northern exposure towards Drake Passage and is described as a moist coastal low-land with a rich moss-grass community, dominated by the grass Deschampsia antarctica (Desv.) and two moss species, Polytrichastrum alpinum (Hedw.) and Sanionia uncinata (Hedw.), a community type commonly found on several islands along the South Shetland Archipelago (CasanovaKatny and Cavieres 2012, Casanova-Katny et al. 2016). 
As part of a long term warming experiment, we established ten Open Top Chambers (OTCs) and matched controls in 2008 at Juan Carlos Point (Casanova-Katny et al. 2016). Open Top Chambers are designed to produce an increase in air temperature by preventing the loss of heat by convection processes and have been commonly used in both Arctic and Antarctic ecosystem studies. The OTC's used here are similar to those used in other warming studies located in Antarctica (Bokhorst et al. 2015, CasanovaKatny et al. 2016, Shortlidge et al. 2016). The chambers are comprised of $3 \mathrm{~mm}$ thick, transparent acrylic panels, assembled into hexagonally shapes which taper to an open top of $40 \mathrm{~cm}$ height and a basal footprint of $106.4 \mathrm{~cm}^{2}$. The acrylic walls have small perforations to allow air exchange and avoid excessive warming. The OTCs were placed on areas identified by researchers as having approximately $80-90 \%$ plant cover (with moss cover approximately 50\% and the remaining percentage being lichen). Matched control sites were marked within $1 \mathrm{~m}$ of each OTC and were selected with similar plant composition and cover, but did not receive treatment (Casanova-Katny et al. 2016).

\section{Abiotic conditions}

To describe microclimate variation produced by the OTCs, air temperature and relative humidity were recorded every hour, throughout one year, with data loggers in both OTC and control plots (HOBO, Pro v2, Onset Computer Corporation, Bourne, MA). For temperature effects, we analyzed monthly air temperature values from February 2008 March 2010. For relative humidity we used values from the spring-summer season (November to March) as this encompasses the time when temperatures exceed freezing and mosses are physiologically active. 
Moss canopy temperatures were measured during a nine-day period in summer 2015 in contiguous patches of each dominant moss species Polytrichastrum alpinum and Sanionia uncinata using thermocouple data loggers inserted approximately $0.5 \mathrm{~cm}$ into the moss canopy (HOBO, UX120-014M, Onset Computer Corporation, Bourne, MA), in both an OTC and a control plot. Soil temperature $\left({ }^{\circ} \mathrm{C}\right)$ and volumetric water content $\left(\mathrm{m}^{3} / \mathrm{m}^{3}\right)$ below moss patches in OTC and control plots were measured during the summer season in 2013-2015 using Decagon EM50 and 5TM soil moisture and temperature sensors (Decagon Devices Inc, Pullman, WA).

\section{Plant and cryptogam community analysis}

Plant and cryptogam communities were assessed by sight for percent cover in 2015, for seven pairs of OTC and control plots, using a $0.5 \mathrm{~m}$ square frame placed in permanently marked blocks in both OTC and control plots. Two researchers conducted the surveys and all points were agreed upon to eliminate single observer bias. Lichens were grouped to genus level and crustose forms were categorized by observable morphology. One vascular grass species, Deschampsia antarctica, was also recorded in the experimental plots.

\section{Moss canopy morphology}

We quantified eight moss canopy characteristics by extracting $2 \mathrm{~cm}$ diameter cores of each dominant moss species Polytrichastrum alpinum and Sanionia uncinata from each of five matched OTCs and control plots. Intact cores were weighed to the nearest mg (dry weight) and electronic calipers (Fisher Scientific, Pennsylvania, USA) were used to 
measure the height of the intact core on a randomly selected location and measurements were binned into four categories: photosynthetic tissue height, senescent tissue height, soil/rhizoid height, and total core height was measured to the nearest mm. Additionally, height of five randomly selected shoots from each core was measured to the nearest $\mathrm{mm}$ to determine canopy height. Mean canopy height was calculated from the shoot measurements and mean core height was calculated from the intact core measurements. Canopy density was determined by counting the number of stems per each core; leaves were denuded from one randomly selected stem from each core to determine leaf density per stem.

\section{Reproductive biology and expressed sex ratios in P. alpinum}

Five matched OTC and control plot $P$. alpinum cores $(2 \mathrm{~cm}$ diameter) were separated and each shoot was counted and confirmed as $P$. alpinum and then categorized by shoot age as: juvenile (very green with leaves still appressed), mature (leafy gametophyte), or senescent (very little to no green tissue, blackening), following the methods of Shortlidge et al. (2016).

Ten randomly-selected shoots from the mature age category were dissected for determination of sex expression, as evidenced by the presence or absence of male sex organs (antheridia), female sex organs (archegonia), the presence of reproductive structures (presence of paraphyses but no gametangia), or purely vegetative (no evidence of gametangia or paraphyses) under compound and dissecting microscopes (Leica, Germany; Leica Application Suite 3.5.0, Germany). Laboratory determinations of sexually expressing gametophytes per core were combined and averaged for warmed 
(OTC) and control plots. Determining the sex of non-sex-expressing gametophytes was beyond the scope of this study.

\section{Bryophyte and invertebrate communities}

We quantified the invertebrate community (presence, absence and abundance) from the dominant moss cover species (Sanionia uncinata and Polytrichastrum alpinum) by extracting replicate $2 \mathrm{~cm}$ diameter cores from paired OTC and control plots, yielding sixteen cores per each experimental treatment.

Invertebrates were extracted using an innovative dried substrate extraction technique, which was tested and found to yield comparable extraction numbers as matched extractions performed with Tullgren extractors from the same site location. Moss cores were placed directly into paper coin envelopes and dried in a $30 \mathrm{C}^{\circ}$ oven for $72 \mathrm{hrs}$. Each core was then carefully removed, placed into a weigh boat and core mass quantified to the nearest $\mathrm{mg}$. Cores were homogenized carefully by hand and divided into two $50 \mathrm{~mL}$ Falcon tubes. Invertebrates were extracted by vigorously shaking the tubes using a 1:3 ratio of kerosene to $95 \%$ Ethanol. The solution was allowed to settle and transfer pipettes were used to extract invertebrates from the kerosene suspension into a petri plate for identification under dissecting microscope (Leica, Germany).

Extracted invertebrates were sorted taxonomically into the following groups: Oribatida, Other mites (Mesostigmata \&Prostigmata), Collembola and Nematoda. Invertebrate abundance was expressed as number of individuals per gram dry weight of substrate. Relative abundance was also quantified as a proportion (\%) of total invertebrate community. 


\section{Statistical Analyses}

To reveal potential changes in vegetative community assemblages between warmed (OTC) and control plots, a percent cover matrix was ordinated using non-metric multidimensional scaling (NMDS) in R studio (Version 0.99.473 2009-2015 RStudio Team 2015) using package "Vegan" (Oksanen et al. 2011). Using Bray-Curtis distance measures and square root data transformation, we chose a two-dimensional solution with the best stress (0.09) based on 20 runs of 1000 permutations. An analysis of similarity (ANOSIM) was used to statistically test for differences between warmed and un-warmed cryptogam species assemblages.

OTC and control plot air temperature and humidity results were obtained from collaborator A. Casanova-Katny (2016), as well as soil temperature and soil water measurements; all data are further described in results section below. Two-way ANOVA was performed to determine the effect of passive warming (OTC vs control) and vegetative percent cover, ontological category (juvenile, mature, senescent), core mass, canopy and core height, leaf density and moss associated invertebrate communities. Tukey's tests were used to determine significance among factors. Unpaired t-tests were used to determine effect of warming on species richness and on $P$. alpinum core density (\# of shoots per core). These data were assessed to fit the assumptions of the ANOVA model and transformations made where indicated. All analyses were conducted using JMP Version 9.0 (SAS Institute 2010), unless otherwise stated. Graph Pad Prism (Version 5.0 for Mac Graph Pad Prism 2007) was used to present graphical results. To determine the effect treatment (OTC and control) and location (individual experimental 
plots) on reproductive output in $P$. alpinum, we used a generalized linear model using JMP Version 9.0 (SAS Institute 2010) with Poisson distribution to account for the large number of zeros in the dataset, which represent low frequency effects rather than missing data values.

\section{Results}

\section{Abiotic conditions}

The OTC treatment significantly increased mean maximum daily air temperature during the study period $(2008-2010)$, from $7.3^{\circ} \mathrm{C}$ in control plots to $10.5^{\circ} \mathrm{C}$ in OTCs (ANOVA, $\mathrm{F}=5.78, \mathrm{p}=0.02)$. However, the passive warming treatment had no significant effect on mean daily temperature or mean minimum daily air temperature (mean site minimum daily air temperature at Juan Carlos Point, $-6.4^{\circ} \mathrm{C}$ ). The highest warming effect measured was during the summer season, with an increase of $0.61^{\circ} \mathrm{C}$ inside the OTCs compared to control plots. These values are similar to other reported values for passive warming experiments in maritime Antarctica, where Bokhorst et al. (2007) measured an increase of $0.7^{\circ} \mathrm{C}$ in annual mean temperature inside OTCs when compared to control plots. The use of OTCs not only affected air temperature, but also produced changed in microclimate. Mean daily relative humidity was significantly lower in the OTCs $(80.7 \%)$ than in control plots $(91.7 \%)$. The mean site daily relative humidity at Juan Carlos Point was $88.5 \%$.

Moss canopy temperatures in OTCs were distinctly higher in both species $(P$. alpinum and $S$. uncinata) than canopy temperatures in control plots across the 9-day sampling period (Figure 4.1, graph courtesy of M. Chmielewski). The highest canopy 
temperatures recorded during the sampling period were in $P$. alpinum located in OTCs $\left(7^{\circ} \mathrm{C}\right)$, however both moss species canopy temperatures cooled to the same degree under warming treatment. Overall, warmed mosses (of both S. uncinata and P. alpinum) had more similar canopy temperature profiles than those of mosses located in control plots.

OTCs increased soil mean temperature $\left({ }^{\circ} \mathrm{C}\right)$ below moss patches, as measured over three years of experimental warming (2013: 32\%, 2014: 19\% and 2015: 44\% of increase with respect to control plots). Mean soil temperature in control plots and OTCs range for 2013 between $2.3( \pm 0.012 \mathrm{SE})$ to $3.41( \pm 0.007 \mathrm{SE})$; for 2014 between $3.03( \pm$ $0.05 \mathrm{SE})$ to $3.60( \pm 0.07 \mathrm{SE})$; and for 2015 from $3.06( \pm 0.07 \mathrm{SE})$ to $4.05( \pm 0.12 \mathrm{SE})$, respectively (Figure 4.2a-c, graph courtesy of A. Casanova-Katny, unpublished data). Temperature fluctuation inside OTCs and controls were observed, but in both treatments temperature fluctuated between 0 to $5^{\circ} \mathrm{C}$. An increase of volumetric water content $\left(\mathrm{m}^{3} / \mathrm{m} 3\right)$ also occurred inside OTC plots (Figure 4.2d-f, graph courtesy of A. CasanovaKatny, unpublished data). This increase is likely part of the snow accumulation or vapor condensation that occurs often during the summer season inside the OTC chambers, which remains during a few days, resulting in more transient water in the soils located under OTCs.

\section{Plant and cryptogam community response to passive warming}

Across the seven OTC and control plots surveyed, we found seven total bryophyte species, Bartramia patens, Bryum pseudotriquetrum, Meesia uliginosa, Pohlia sp., Polytrichastrum alpinum, Sanionia uncinata, and Syntrichia saxicola (see Table 4.1). 
Two species of bryophytes occurred only in warmed (OTC) plots, Bartramia patens and Pohlia sp. Overall, percent vegetative cover did not change under passive warming (Figure 4.4b, two-way ANOVA, $\mathrm{F}=0.65, \mathrm{p}=0.53, n=7$ ). However, a significant decrease was seen in Sanionia uncinata percent cover in OTC plots compared to control plots (Figure 4.4a, two-way ANOVA, $\mathrm{F}=2.36, \mathrm{p}=0.03, n=7$ ), but no effect was observed for other bryophyte species (Figure 4.4a, two-way ANOVA, $\mathrm{F}=0.99, \mathrm{p}=0.32, n=7$ ). We categorized eight unique lichen morphologies in total and summed the values to find total percent (\%) lichen cover; no significant change in lichen cover occurred between warmed (OTC) and control plots (Figure 4.4b, two-way ANOVA, $\mathrm{F}=0.65, \mathrm{p}=0.53, n=7$ ). Additionally, one vascular plant species, the Antarctic Hair Grass, Deschampsia Antarctica was also detected; no significant changes in percent cover were detected with warming (Figure 4.4b, two-way ANOVA, $\mathrm{F}=0.65, \mathrm{p}=0.53, n=7$ ). Additionally, NMDS ordination of cryptogam communities showed that community composition showed no detectable compositional changes (as measured by percent cover) after eight years of passive warming (Figure 4.3, NMDS, Stress=0.09; ANOSIM test statistic $\mathrm{p}=0.35, n=7$ ). All plots were abundant with vegetation and no bare ground or rock substrate was recorded, which is as expected given the site lies in a moist, coastal lowland that is rich with cryptogamic vegetation. Similarly, alpha diversity (species richness) was not significantly affected by treatment (t-test, $\mathrm{p}=0.34$, OTC: $7 \pm 0.9 \mathrm{SE}$; Control: $6 \pm 0.5 \mathrm{SE}$, $n=7$ ) except for the occurrences of Bartramia patens and Pohlia sp., which only occurred in warmed (OTC) plots (Table 4.1).

\section{Bryophyte canopy morphology under passive warming}


Despite eight years of passive warming, no significant differences in moss canopy morphology were observed in the dominant moss species Polytrichastrum alpinum and Sanionia uncinata. Core mass (DW g) (Figure 4.5c, two-way ANOVA, $\mathrm{F}=2.23, \mathrm{p}=0.15$, $n=5$ ); photosynthetic tissue height, senescent tissue height, soil/rhizoid height, total core height, and canopy height of individual stems showed no measurable differences between warmed (OTC) and control plots for both species (Figure 4.5a/b, P. alpinum: two-way ANOVA, F=0.44, $\mathrm{p}=0.51, n=12 ;$. uncinata: two-way ANOVA, F=1.94, $\mathrm{p}=0.17, n=6$ ). Canopy density (\# of stems per cores) did not differ between treatments in P. alpinum (ttest, $\mathrm{p}=0.48, n=5$ ), nor did density (\#) of leaves per stem in and out of warmed plots for either species (Figure 4.5d, two-way ANOVA, $\mathrm{F}=1.78, \mathrm{p}=0.20, n=5$ ).

\section{Reproductive biology and expressed sex ratios in P. alpinum}

Control plots overall contained more gametophytes per core in each ontological category (juvenile, mature, senescent) than warmed (OTC) plots, but the effect was not significant with treatment (Figure 4.6, two-way ANOVA, $\mathrm{F}=0.58, \mathrm{p}=0.63, n=5$.). Within ontological categories, OTC plots contained significantly fewer juvenile stems than senescent stems (Figure 4.7, two-way ANOVA, $\mathrm{F}=2.05, \mathrm{p}=0.04, n=5$ ). $P$. alpinum gametophytes expressing sex organs differed significantly between warmed (OTC) and control plots; warmed (OTC) plots exhibited significantly more female sex expression than control plots (Figure 4.8, GLM, $\mathrm{X}^{2}=31.24, \mathrm{p}=0.001, n=50$ ). Control plots showed generally higher occurrence of paraphyses, but the effect was not significant (Figure 4.8, GLM, $\left.\mathrm{X}^{2}=12.51, \mathrm{p}=0.13, n=50\right)$. No sporophytes were observed during the sampling season. 


\section{Bryophyte and invertebrate communities under passive warming}

Invertebrate extractions from binned dominant moss species, Polytrichastrum alpinum and Sanionia uncinata, revealed that warmed plots (OTC) had significantly higher numbers of microarthropods (Oribatid mites and Collembola) than control plots (Figure 4.9a, two-way ANOVA, $\mathrm{F}=10.60, \mathrm{p}=0.001, n=16)$. We additionally examined the relative frequency of each invertebrate group (Oribatida, Collembola, and Nematoda) and found a significantly lower frequency of soil nematodes in warmed (OTC) plots than control plots (Figure 4.9b, two-way ANOVA, $\mathrm{F}=7.72, \mathrm{p}=0.001, n=16$ ). Binned moss species were separated to examine moss species-specific effects on invertebrate communities under passive warming, and we found significantly higher numbers of Folsomia sp. in warmed

S. uncinata than control S. uncinata moss cores (Figure, 4.10a, two-way ANOVA, $\mathrm{F}=5.88, \mathrm{p}=0.01, n=8)$ and significantly more number of nematodes hosted under $P$. alpinum than S. uncinata, particularly in warmed plots (OTC) (Figure 4.10b, two-way ANOVA, F=13.17, $\mathrm{p}=0.001, n=6)$. We explored the relationship between the presence of moss reproductive structures and total number of invertebrates by linearly regressing total microarthropods (Oribatid mites and Collembola) against the number of female sex structures detected in P. alpinum and the correlation $\left(\mathrm{r}^{2}=0.64\right)$ indicated the strength of the relationship.

\section{Discussion}

Here we present results of eight years of experimental warming on a moss ecosystem in maritime Antarctica. Experimental warming had distinct and significant impacts on both microclimate conditions and bryophytes communities located in OTCs. We found an 
increase of female sex expression in $P$. alpinum under passive warming compared to those without warming. Moss communities under warming also had substantially larger total invertebrate communities than those in control moss communities, and invertebrate communities were significantly affected by moss species and moss reproductive effort. Our results suggest that increasing warming on the western Antarctic peninsula will have distinct impacts on moss reproductive biology and hold implications for the microorganism and invertebrate communities they sustain (Convey et al. 2009).

\section{Thermal effects observed in bryophytes under experimental warming}

We found that OTC warming treatments were successful at increasing air temperature during the study period, as they are designed to do, and additionally moss canopy temperatures, soil temperature, and volumetric water content below mosses also increased in OTC treatments (Figure $4.1 \&$ Figure 4.2). Alternatively, relative humidity, as measured in air, decreased in OTCs, further showing the rather complex sets of abiotic responses when using passive warming chambers. Our abiotic results are similar to those generated in other Antarctic studies utilizing OTC chambers, see Bokhorst et al. (2011) for review on passive warming methods in the Antarctic. Yet, a large variation of abiotic conditions have been generated using OTCs (Bokhorst et al. 2011), some which are opposed to our findings, which further elucidates the variation of terrestrial, ice-free sites found along the western Antarctic peninsula and the varied methods of measurement (air, soil, \& moss canopy) and challenges selecting equipment sturdy enough to overwinter and provide long term datasets may also be factors related to the diversity of abiotic site results generated from OTC Antarctic studies as a whole. 
We found mosses in OTCs had distinctly higher canopy temperatures than those located in controls, and species-specific canopy temperature differences occurred between $P$. alpinum and $S$. uncinata, with higher canopy temperatures occurring in $P$. alpinum (Figure 4.1). Additionally, we found coupled effects of increasing soil mean temperatures and volumetric water content below warmed (OTC) mosses (Figure 4.2) suggests that rapid climate warming along the western Antarctic peninsula will fundamentally affect the way which moss canopies interface between the atmosphere and soils and how that interface will continue to function on the terrestrial landscape of Antarctica. Moss cover can reduce the exchange of heat between the atmosphere and soil, providing an insulating effect which decreases soil temperatures and protects permafrost (Turetsky et al. 2010, Porada et al. 2016) and further can provide habitat for microfauna adapted to the Antarctic ecosystem (Convey 1996a, Pugh and Convey 2008). A reduction of surface cover of cryptogams or changes in the insulating capacity of moss species will hold dramatic effects for soil temperatures, thawing of permafrost, communities of microfauna, and processes of ecosystem succession (Longton 1997, Turetsky 2003, Porada et al. 2016). Understanding the variability of these species-specific responses to climate warming is essential as differential effects may be observed on fundamental terrestrial processes and the ability of cryptogam communities to structure other essential communities of microorganisms and invertebrates.

\section{No effects of experimental warming on cryptogam community composition}

After eight years of passive warming, we observed no distinguishable effects on cryptogam community composition or species richness, a finding consistent with other 
Antarctic passive warming studies (Bokhorst et al. 2007, 2015) (Figure 4.3 \& Figure 4.4b). However, we did find Bartramia patens occurred only in warmed (OTC) plots (Table 4.1), a common species recorded in other Antarctic studies (Convey and Smith 1993a, Marshall and Convey 1997) and within OTC experiments (Casanova-Katny et al. 2016, Shortlidge et al. 2016) that found experimental warming has a positive effect on $B$. patens sexual reproduction and sporophyte size (Casanova-Katny et al. 2016). This occurrence may also be due to the perennial nature of this species and its large investment in producing sporophytes with large spores (Convey and Smith 1993a, Marshall and Convey 1997), suggesting it may also be a successful disperser overall on the Antarctic landscape. Pohlia sp. was also detected in only OTCs, but only as single isolated occurrence (Table 4.1).

We further found that percent cover of $S$. uncinata significantly decreased in warmed plots (Figure 4.4a), consistent with Nakatsubo (2002), who showed a distinct reduction of carbon gain in S. uncinata on King George Island under projected warming regimes. This conclusion is in contrast to common idea that suggests increasing temperatures will lead to an increase in the rate of gross photosynthesis and respiration, in turn leading to higher productivity of Antarctic mosses (Davey and Rothery 1997). Yet studies by Convey (1994) and Nakatsubo (2002) determined a small ratio of net photosynthesis $\left(P_{n}\right)$ to dark respiration $(R)$ for many species of mosses in maritime Antarctica, including $S$. uncinata, which suggests reduced carbon gain for mosses with low $P_{n} / R$ ratios under climatic warming, which may be related to the significant decrease in percent cover of this species after eight years of experimental warming found in this study. 


\section{Positive effects of warming on $P$. alpinum reproductive biology}

Our study is one of only two other studies to our knowledge that explores the effects of warming on moss reproductive output (Casanova-Katny et al. 2016, Shortlidge et al. 2016). We found that $P$. alpinum in warmed (OTC) plots exhibited significantly more female sex expression than control plots (Table 4.2 \& Figure 4.8), similar to findings in two other Antarctic bryophyte studies (Casanova-Katny et al. 2016, Shortlidge et al. 2016). Casanova-Katny et al. (2016) found significant increases in sporophyte production in $P$. alpinum under passive warming OTC treatments after seven years of experimental warming, however we found no sporophytes in $P$. alpinum during our study. Our results are similar to those of Shortlidge et al. (2016), who found increases in individual female and male gametangia production, but no increase in sporophyte production, in P. alpinum which suggests that warming may relieve environmental constraints on reproductive effort. Sexual reproduction in mosses may be limited by many factors such as spermlimitation (Rydgren et al. 2006), resource limitation (Stark et al. 2000, 2009), and abiotic stress (Bowker et al. 2000, Eppley et al. 2011). No males were observed during our study, which may be an additional barrier to reproductive success (i.e. sperm limitation). In maritime Antarctica, moss sexual reproduction has been observed (Convey and Smith 1993b, Convey 1994b) and has been shown to occur across wide latitudinal gradients (Lewis Smith and Convey 2002), but is also typically limited to occurring the geothermal areas of Deception Island (Smith 2005a). Despite rapid climate warming on the Antarctic peninsula, few studies have begun to address the effect of warming on moss reproduction. Our results provide further evidence that despite experimental warming, 
there may still be limitations on the reproductive success of $P$. alpinum, which Shortlidge et al. (2016) indicated, and present interesting research areas for future study. However, increasing climate warming on the Western Antarctic peninsula is anticipated to encourage the growth and spreading of moss vegetation in Antarctica, which will further influence terrestrial ecosystem succession (Turetsky 2003, Convey et al. 2009).

Our findings also identified a strong correlation $\left(\mathrm{r}^{2}=0.64\right)$ between number of female sex structures and abundance of microarthropods, a novel finding which has not been shown in any other moss studies, to our knowledge, apart from Rosenstiel et al. (2012) who showed that collembola preferentially chose female mosses over male mosses when presented a choice experiment. The reason for this pattern is not known, but may be that sugars excreted by gametangia (Cronberg et al. 2006) could be serving as a food source or it may be related to the different volatile scent profiles luring microarthropods to fertile moss shoots (Rosenstiel et al. 2012). Studies show that sexual reproduction in mosses can be facilitated by microarthropod communities which inhabit them (Cronberg et al. 2006, Rosenstiel et al. 2012). If mosses increase investment in reproductive efforts in response to warming and microarthropod communities similarly respond positively, as our study has shown, these coupled responses could present fewer barriers to reproduction and sperm transport in the moss communities of Antarctica. Further, few studies have discussed the magnitude of importance moss vegetation has on structuring fundamental communities of microfauna, creating links to fundamental terrestrial processes in Antarctic ecosystems. These results are key in understanding the effects of warming on moss reproductive efforts and the capacity of moss species to structure communities of invertebrates and microorganisms. 


\section{Warming differentially effects moss-dwelling invertebrate communities}

Differential responses were observed for invertebrate communities extracted from bryophytes under eight years of passive warming treatment (OTCs) compared to controls (Figure 4.9a, b). We found that overall microarthropod abundance increased in warmed (OTC) plots compared with control plots (Figure 4. 9a/b). Specifically collembola (Folsomia sp.) abundance was significantly greater in S. uncinata located in warmed plots than control plots (Figure 4.10a). These results are similar to those found by Day et al. (2009) who found increased abundance of microarthropods under summer warming and increased water addition on the Antarctic peninsula. However, mixed results have been common from warming experiments examining microarthropod abundance (Bokhorst et al. 2008). Bokhorst et al. (2015) found little effect after 10 years of passive warming (OTCs) on invertebrate communities on Signy Island, while Convey et al. (2002) showed significant declines in endemic collembola with warming as a result of desiccation. For microarthropods in moss ecosystems, moisture has been found to have a larger effect than temperature on abundance (Turnbull and Lindo 2015). In our warmed plots, relative humidity decreased but soil water content increased, suggesting the plots were moister belowground but perhaps not at upper levels of plant canopies. Ultimately, it is clear that temperature-moisture regimes and microsite variation may have the most distinct influences on microarthropod communities in maritime Antarctica (Convey et al. 2002, Day et al. 2009), and terrestrial site variation may be an important factor as invertebrates in wet sites may be differentially affected by warming experiments than those on drier or rocky sites in general. 
While positive effects of warming were observed on microarthropod communities, warming had a negative effect on abundance of soil nematodes (Figure 4.10b), and P. alpinum was found to host a higher abundance of nematodes than $S$. uncinata (Figure 4.10b), suggesting species specific effects exist for the capacity of Antarctic mosses to host invertebrates. We found that volumetric soil water and soil temperature increased in warmed plots compared to control plots, and this may have affected nematode abundance. Mouratov et al. (2001) found that the abundance of Antarctic soil nematodes on King George Island was negatively correlated with soil water content. Additionally, Mouratov et al. (2001) found nematode abundance varied with plant host species, showing higher abundances under $D$. antarctica when compared to $S$. uncinata, similar to findings in our study which revealed higher abundances under $P$. alpinum than $S$. uncinata. This species-specific result is particularly important for considering the importance of Antarctic terrestrial vegetation for contributing to both biodiversity and increasing the ability of the terrestrial landscape to host microorganisms and invertebrates important in food web and decomposition dynamics in Antarctica.

The differential effects of warming on microarthropods and soil nematode abundance may be related to changing abiotic conditions in OTC chambers compared with control plots. Barcikowski and Loro (1999) found species specific differences in seasonal moss water content, showing that water content was both higher and less variable in $P$. alpinum when compared to $S$. uncinata, further detailing how moss species can provide differential effects on the surrounding terrestrial environment. The availability of water and species-specific variation in moss water content and canopy temperatures we found with warming may influence both moss and soil fungi and 
microbial diversity, resulting in differential effects on microarthropod and soil nematode communities associated with bryophytes. In this study, we found that fungi amount and diversity in soil was higher in OTC versus controls for these same sites (Casanova-Katny, unpublished data). The increase in soil fungi may be a combined result of species-specific differences in water holding capacity and an increase in soil water, both of which could drive fungal populations and provide a positive food source for the microarthropod community in OTC chambers. In contrast, the common species of Antarctic nematodes on King George Island are dominantly microbial feeders (Lavian et al. 2001) which may be one factor for why abundance of soil nematodes showed opposite patterns to that of microarthropods as their feeding patterns may be less influenced by fungal load (presence/abundance). More work is needed to better understand the effects of warming on bryophyte communities (including species-specific responses and changing abiotic canopy factors) and the resulting implications for invertebrate and microorganism communities.

\section{Conclusions}

This work has shown that Antarctic moss communities respond to eight years of experimental warming. We found species-specific responses to passive warming, showing higher canopy temperatures and differential shifts in invertebrate communities in two dominant moss species, $P$. alpinum and S. uncinata. Further, we observed that warming increased reproductive output of $P$. alpinum, which was also linked to microarthropod abundance, illustrating the broad range of species-specific biological responses related to climate warming in terrestrial Antarctica bryophyte communities. 
Many challenges remain to understand impacts of changing environmental conditions on terrestrial communities in Antarctica, a major task is the still insufficient knowledge about terrestrial biodiversity and how such biodiversity links to larger ecosystem components in light of continued climate warming (Convey et al. 2014, Chown et al. 2015). Microarthropods play a key role in nutrient cycling within soil ecosystems, yet in the Antarctic terrestrial ecosystem these processes have been shown to be largely governed primarily by climatic parameters (Convey 1996b, Smith 2005b, Bokhorst et al. 2008). Further studies to expand on species-specific responses of cryptogam communities to warming and the resulting implications for their ability to structure microorganism and invertebrate communities will greatly increase our understanding of potential impacts for terrestrial ecology in a rapidly warming Antarctic ecosystem.

\section{Acknowledgements}

This work was funded by the US National Science Foundation (PLR 1341742 to S.M.E and T.N.R). Thanks to the Chilean Antarctica Institute (INACH) for financial and logistical support and to A. Casanova-Katny for developing the OTC project and for inviting collaboration. Thanks to John Christy for identification of voucher samples. Further thanks to P. Zuniga, S. Kiel, S. Derkarabetian, C. Maraist, M. Chmielewski, A. Clements, J. Shamek, S. Herrejon Chavez, E. Leal, and T. Deakova for field, technical, and laboratory support. 
Table 4.1 List of cryptogamic and plant species cover detected in ground cover surveys of warmed (OTC) and un-warmed $(\mathrm{CON})$ plots $(n=7)$. Two bryophyte species were found only in warmed (OTC) plots, indicated in bold typeface below.

\begin{tabular}{llc}
\hline Scientific Name & \multicolumn{2}{c}{ Number of Detections } \\
& OTC & CON \\
\hline Bryophytes & & \\
Bartramia patens & $\mathbf{4}$ & 0 \\
Bryum pseudotriquetrum & 5 & 3 \\
Meesia uliginosa & 4 & 4 \\
Pohlia sp. & $\mathbf{1}$ & 0 \\
Polytrichastrum alpinum & 7 & 5 \\
Sanionia uncinata & 7 & 7 \\
Syntrichia saxicola & 1 & 1 \\
\hline Lichens & 7 & 7 \\
\hline Grasses & & \\
Deschampsia Antarctica & 5 & 4 \\
\hline
\end{tabular}


Table 4.2 Sex expression in P. alpinum cores of warmed (OTC) and un-warmed (CON) plots. Ten mature shoots from each core were assessed for presence of sex structures or paraphyses; all cores contained gametophytes with the presence of sex organs. Summary statistics are shown by treatment. Total gametophyte number per core and total gametophyte bud number per 10 mature shoots is also shown. Sex expression is shown in parentheses as proportion (\%) of gametophyte buds assessed per sample. Mean values are indicated in bold typeface.

\begin{tabular}{|c|c|c|c|c|c|}
\hline Treatment & & $\begin{array}{c}\text { Total } \\
\text { gametophyte } \\
\text { number/core } \\
\end{array}$ & $\begin{array}{c}\text { Total } \\
\text { gametophyte } \\
\text { buds /10 shoots }\end{array}$ & Female exp. Sex & Male exp. Sex \\
\hline \multirow[t]{6}{*}{$\mathrm{CON}$} & $n=5$ & & & & \\
\hline & mean & 83 & 16 & $6(38 \%)$ & $\mathbf{0}$ \\
\hline & sd & 20 & 5 & 4.1 & 0 \\
\hline & se & 9 & 2 & 1.8 & 0 \\
\hline & $\max$ & 112 & 10 & 9 & 0 \\
\hline & $\min$ & 60 & 24 & 0 & 0 \\
\hline \multirow[t]{6}{*}{ OTC } & $n=5$ & & & & \\
\hline & mean & 72 & 16 & $10(63 \%)$ & $\mathbf{0}$ \\
\hline & sd & 35 & 4 & 4.9 & 0 \\
\hline & se & 16 & 2 & 2.2 & 0 \\
\hline & $\max$ & 122 & 11 & 16 & 0 \\
\hline & $\min$ & 38 & 20 & 2 & 0 \\
\hline
\end{tabular}


Figure 4.1 Mean moss canopy temperatures $\left({ }^{\circ} \mathrm{C} \pm 95 \% \mathrm{CI}\right)$ show across nine-day sampling period in $P$. alpinum and $S$. uncinata in both OTC and control plots. OTC moss canopy temperatures trend warmer than control moss canopies (graph courtesy of M. Chmielewski).

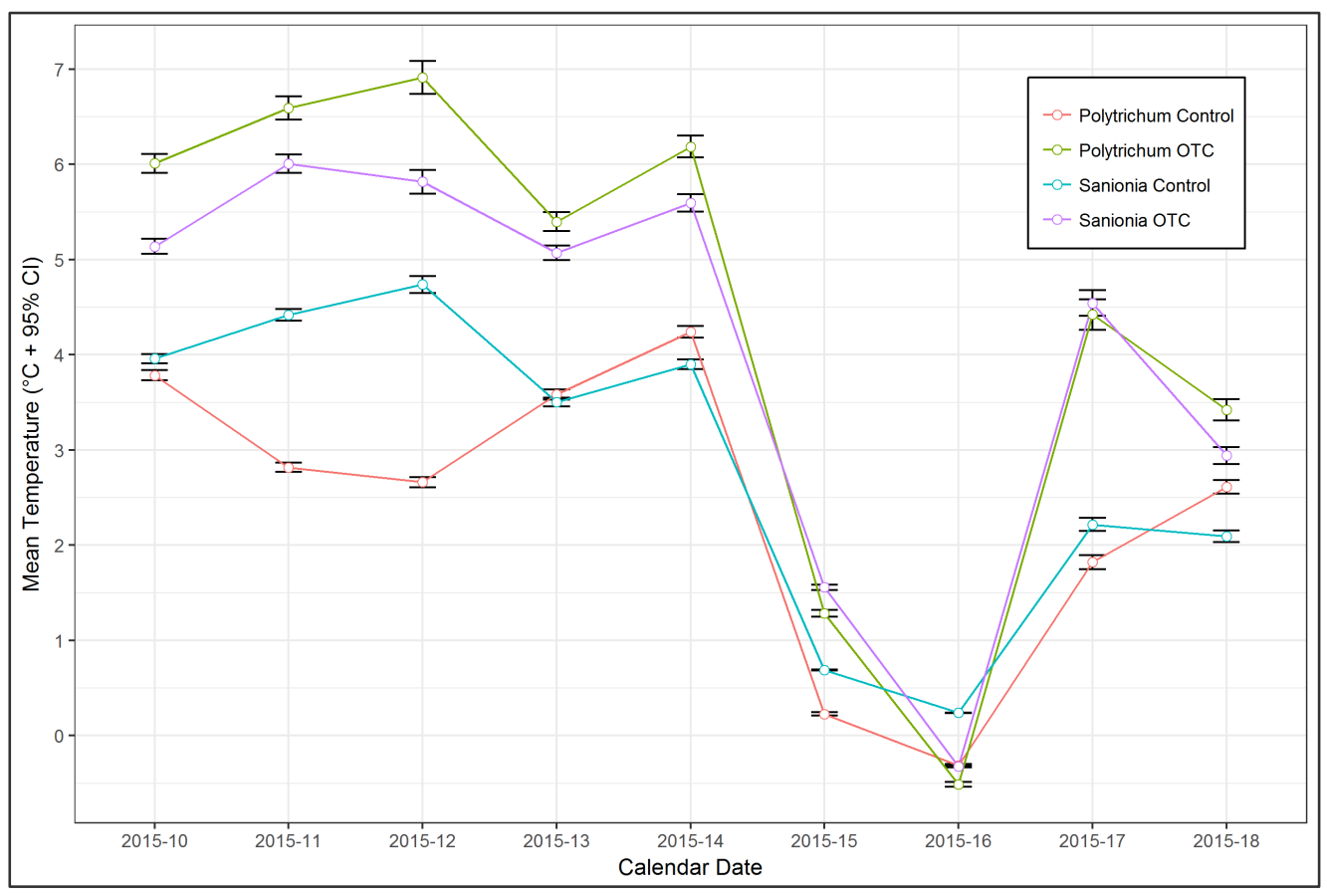


Figure 4.2 Experimental passive warming with OTCs results in an increase of soil mean temperature $\left({ }^{\circ} \mathrm{C}\right)$ and volumetric water content $\left(\mathrm{m}^{3} / \mathrm{m}^{3}\right)$ below mosses, values below shown for three years of warming (2013-2015). a-c) Mean ( \pm SE) soil temperature $\left({ }^{\circ} \mathrm{C}\right)$ recorded below mosses for 2013, 2014, and 2015; d-f) Mean $( \pm \mathrm{SE})$ volumetric water content $\left(\mathrm{m}^{3} / \mathrm{m}^{3}\right)$ recorded below mosses for 2013, 2014, and 2015 in OTC and control plots (graph courtesy of A. Casanova-Katny, unpublished data).

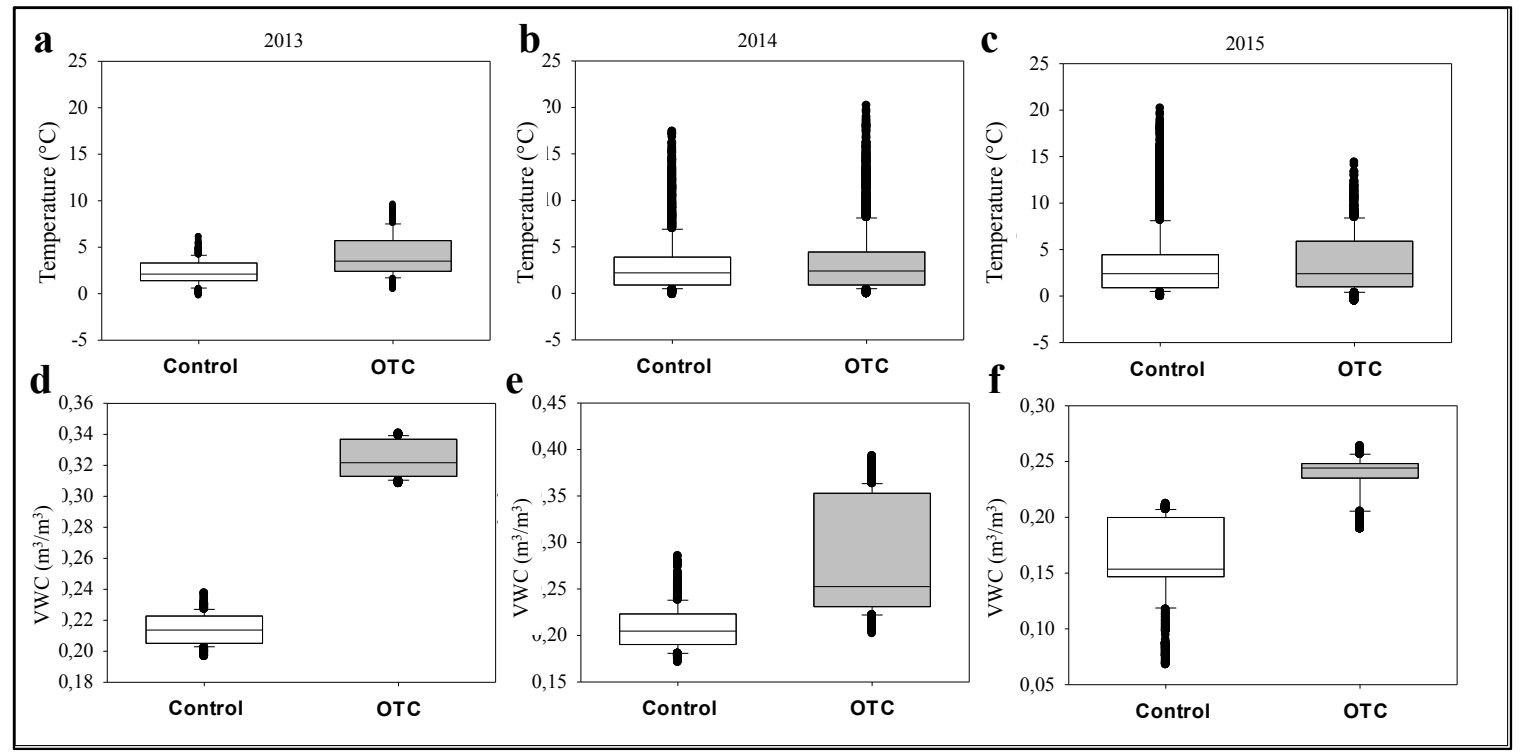


Figure 4.3 Cryptogam community assemblages were ordinated using nonmetric multidimensional scaling (NMDS). No changes in cryptogam community composition occurred after eight years of passive warming (2008-2016); Stress=0.09; ANOSIM test statistic $\mathrm{p}=0.348, n=7$. Bray-Curtis distance measure was used on square root transformed data; distances between points are proportional to the dissimilarities between entities. Differing symbols represent treatment and control plots, as shown with the corresponding plot labels.

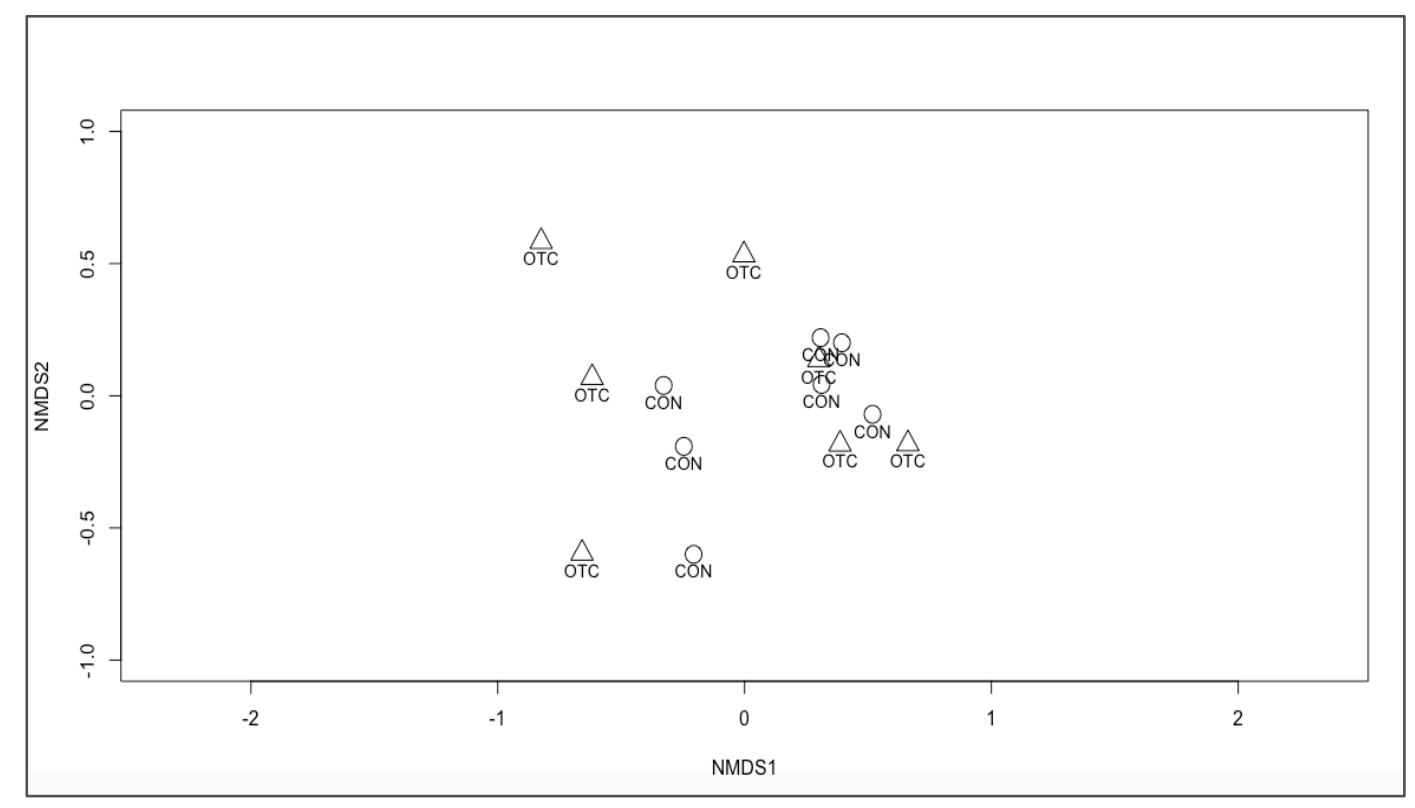


Figure 4.4 Vegetative percent cover by experimental warming treatment. a) Mean $( \pm \mathrm{SE})$ percent bryophyte cover for warmed (OTC) and control (CON) plots; a significant decrease in percent cover of $S$. uncinata was observed in warmed (OTC) plots ( $p=0.03$, $n=7)$ after eight years of passive warming. b) Mean $( \pm$ SE) percent vegetative cover for warmed (OTC) and control (CON) plots, no significant changes were observed in plant percent cover after eight years of passive warming treatment $(\mathrm{p}=0.53, n=7)$.
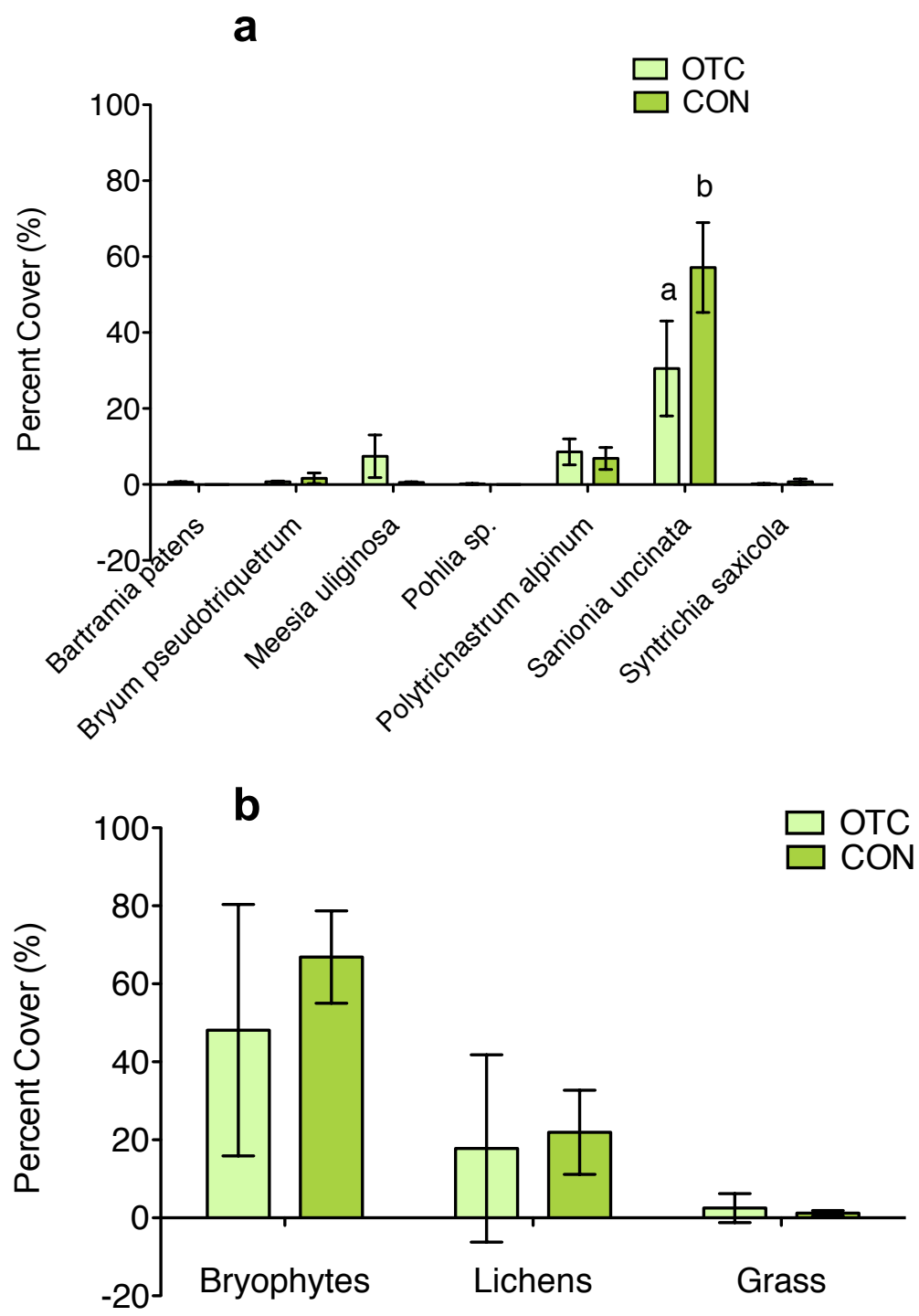
Figure 4.5 Mean values ( \pm SE) for three moss canopy morphology metrics measured in Polytrichastrum alpinum and Sanionia uncinata. Despite eight years of passive warming, no significant differences in moss canopy morphology were observed in the dominant moss species $P$. alpinum and $S$. uncinata between OTC and control plots. a) photosynthetic tissue height, senescent tissue height, soil/rhizoid height, total core height (mm) for P. alpinum ( $\mathrm{p}=0.51, n=12)$; b) photosynthetic tissue height, senescent tissue height, soil/rhizoid height, total core height $(\mathrm{mm})$ for $S$. uncinata $(\mathrm{p}=0.17, n=6)$; c) core mass DW $(\mathrm{g})(\mathrm{p}=0.15, n=5)$; d) density $(\#)$ of leaves per stem shown for both species $(\mathrm{p}=0.20, n=5)$.
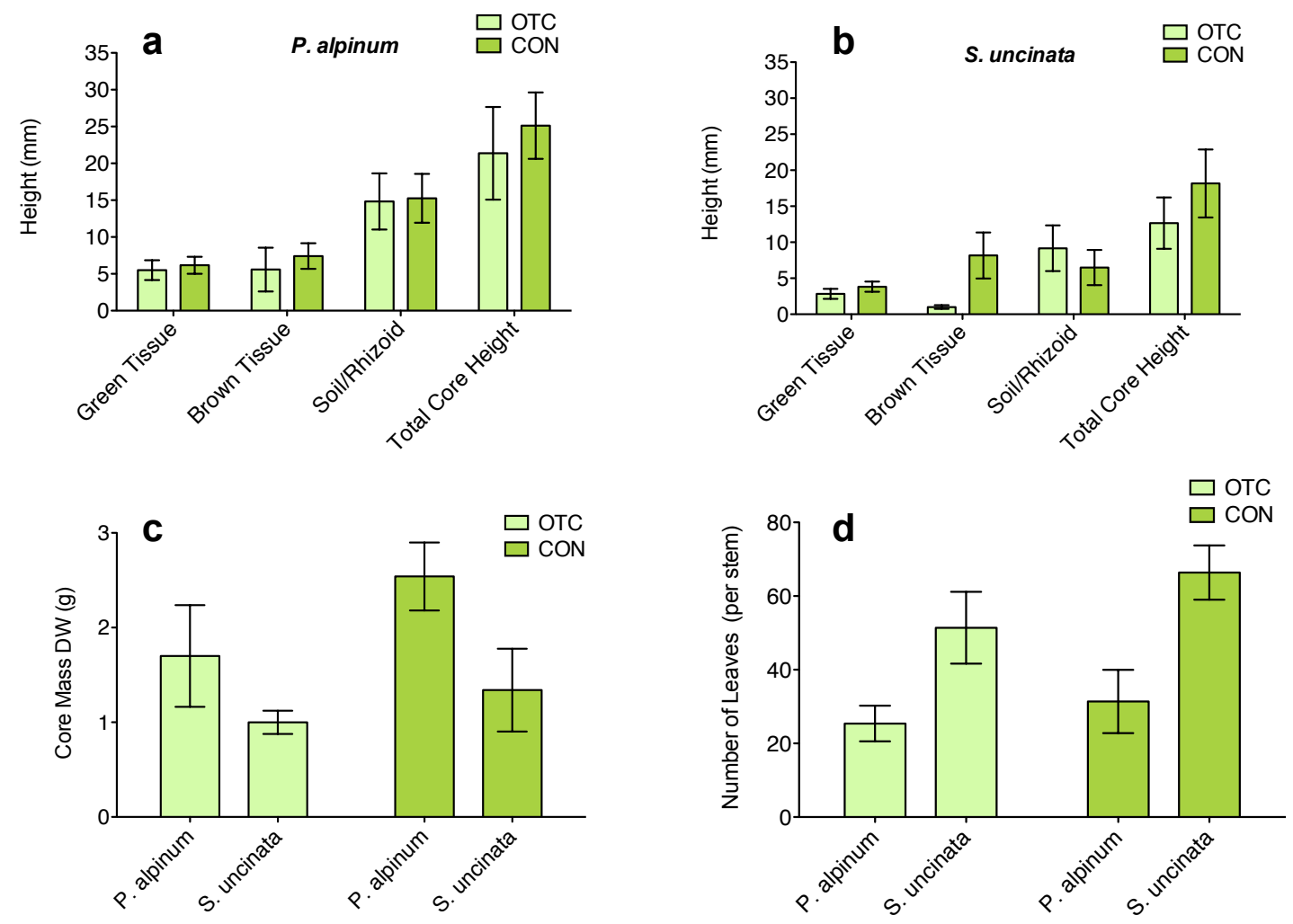
Figure 4.6 Mean $( \pm \mathrm{SE})$ count of ontological (age) categories per core collected from warmed (OTC) and control (CON) plots. Individual gametophytes were classed into three ontological stages (juvenile, mature, and senescent) and total numbers of gametophytes were quantified per core. No significant differences were observed between passive warming treatment and controls $(\mathrm{p}=0.59, n=5)$ and no significant differences occurred among ontological classes $(\mathrm{p}=0.35, n=5)$.

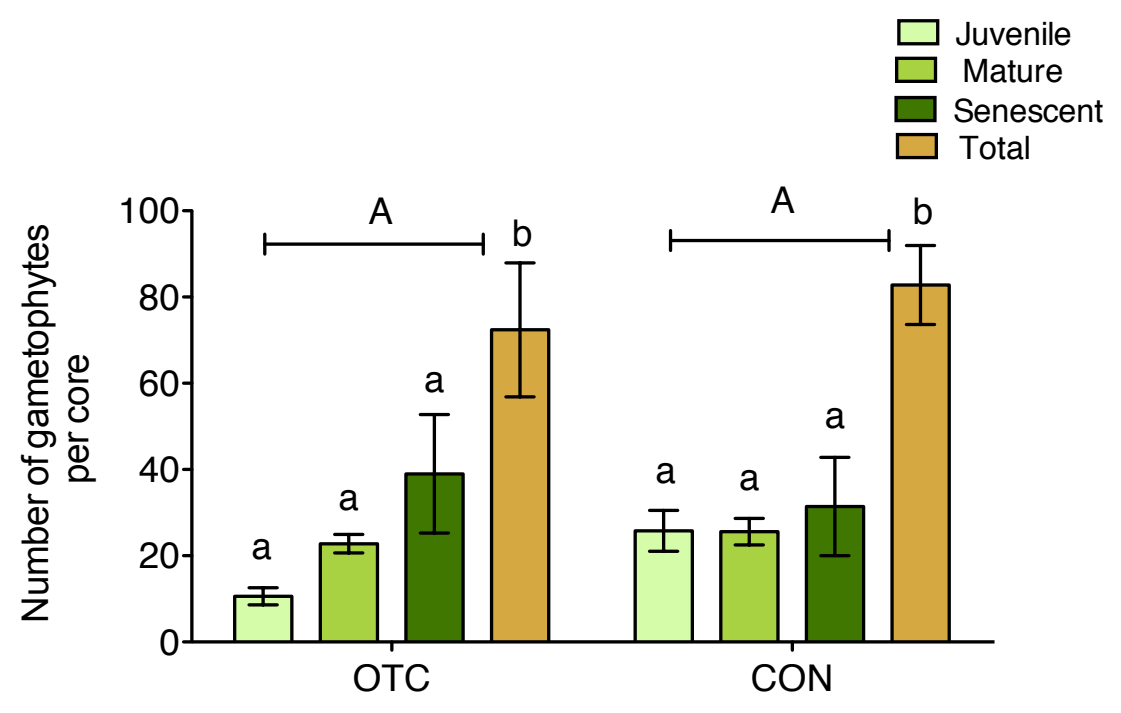


Figure 4.7 Mean ( \pm SE) proportion (\%) of ontological categories per core collected from warmed (OTC) and un-warmed (CON) plots. Individual gametophytes were classed into three ontological stages (juvenile, mature, senescent) and total number of gametophytes was quantified per core and proportion (\%) of each category per core was calculated. No significant differences were observed between warming treatment (OTC) and controls ( $\mathrm{p}=0.59, n=5$ ), but among ontological classes, significantly fewer juvenile gametophytes were found than senescent gametophytes in OTCs $(\mathrm{p}=0.04, n=5)$.

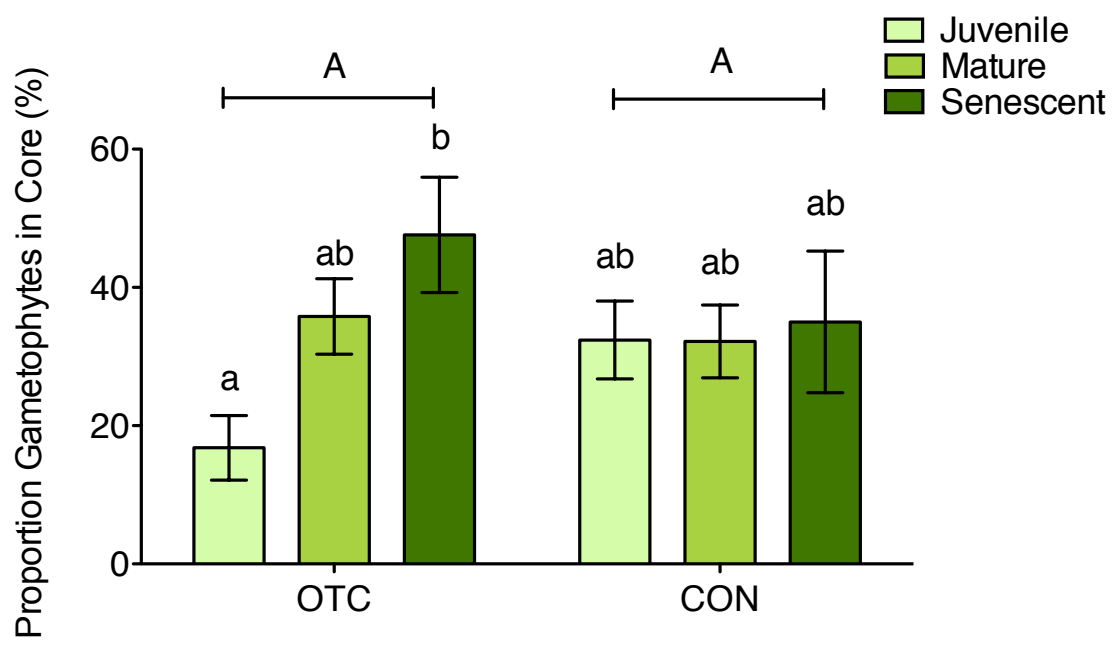


Figure 4.8 Mean $( \pm \mathrm{SE})$ sex expression per gametophyte buds in Polytrichastrum alpinum. Gametophytes expressing sex organs differed between warmed (OTC) and control (CON) plots. Warmed (OTC) plots exhibited more female sex expression than control plots $(\mathrm{p}=0.001, n=50)$. Control $(\mathrm{CON})$ plots showed higher occurrence of paraphyses, but the effect was not significant ( $\mathrm{p}=0.13, n=50$ ).

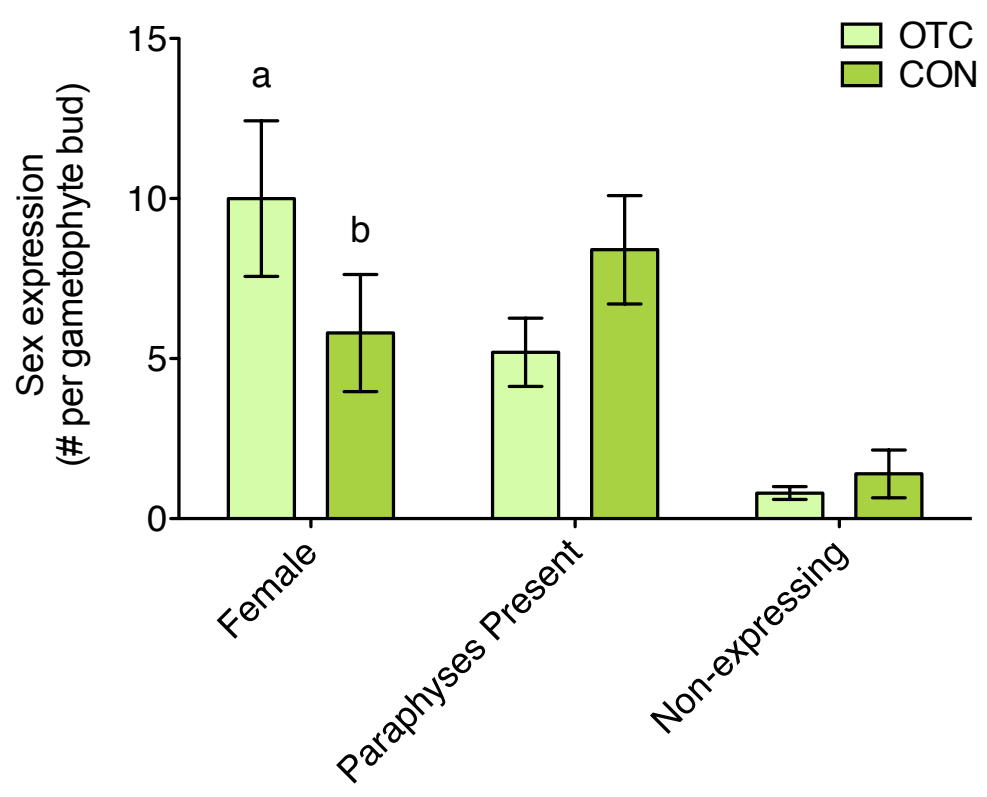


Figure 4.9 a) Mean $( \pm \mathrm{SE})$ microarthropods (per g/DW moss) extracted from two dominant moss species (P. alpinum and $S$. uncinata) in warmed (OTC) and control $(\mathrm{CON})$ plots; significantly more total microarthropods (oribatid mites and collembola) were found in warmed plots than control plots $(\mathrm{p}=0.001, n=16)$. b) Mean $( \pm \mathrm{SE})$ relative frequency of invertebrates (oribatid mites, collembola, and nematodes) extracted from two dominant moss species (P. alpinum and $S$. uncinata) in warmed (OTC) and unwarmed $(\mathrm{CON})$ plots; significantly more nematodes were found in control plots than warmed plots $(\mathrm{p}=0.001, n=16)$.
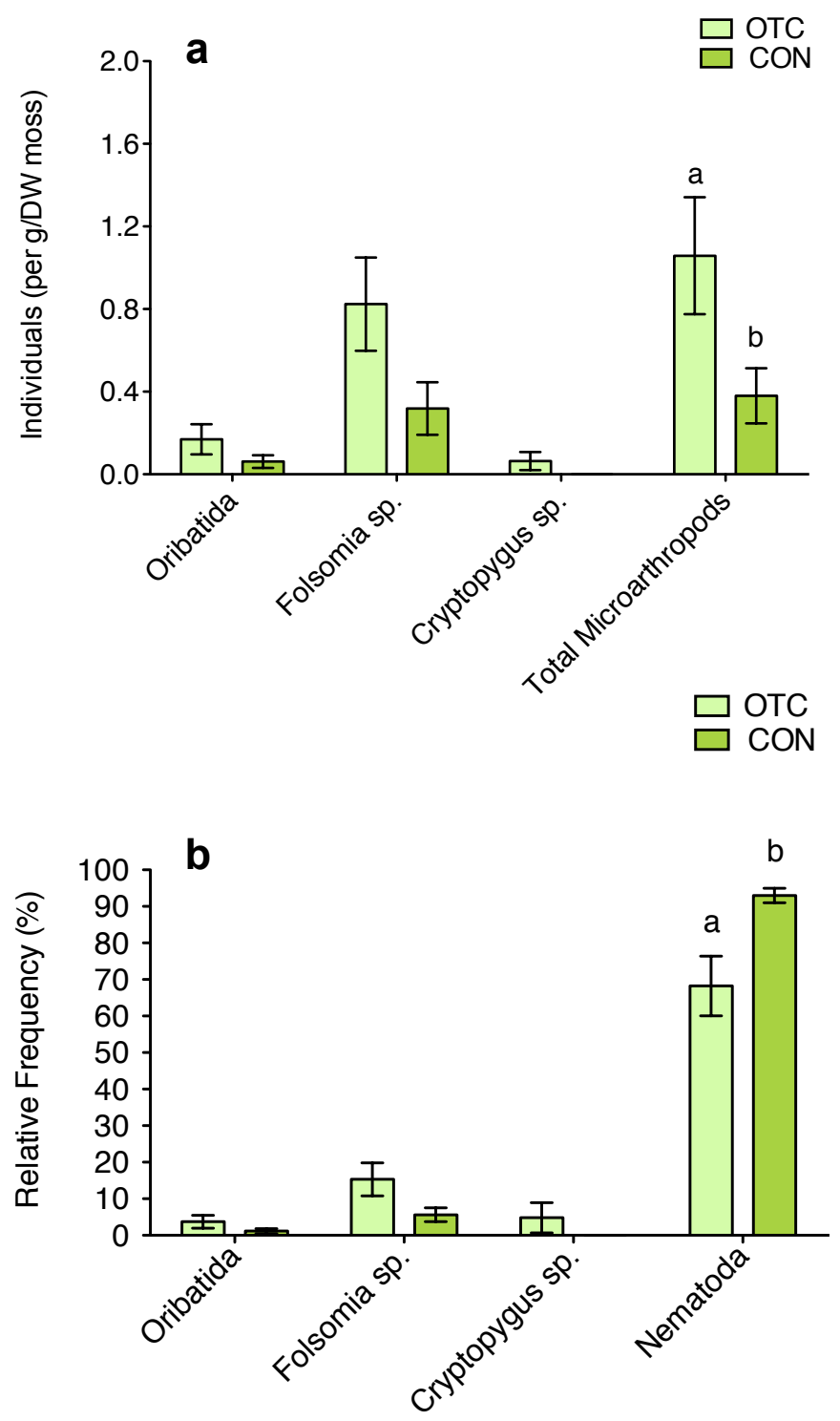
Figure 4.10 Mean $( \pm \mathrm{SE})$ invertebrates (per g/DW moss) extracted from two dominant moss species ( $P$. alpinum and $S$. uncinata) in warmed (OTC) and control (CON) plots. a) Significantly more Folsomia $s p$. were found in warmed $S$. uncinata moss cores than control $S$. uncinata moss cores $(\mathrm{p}=0.01, n=8)$. b) Significantly more nematodes were found in $P$. alpinum cores than in $S$. uncinata cores $(\mathrm{p}=0.001, n=6)$.
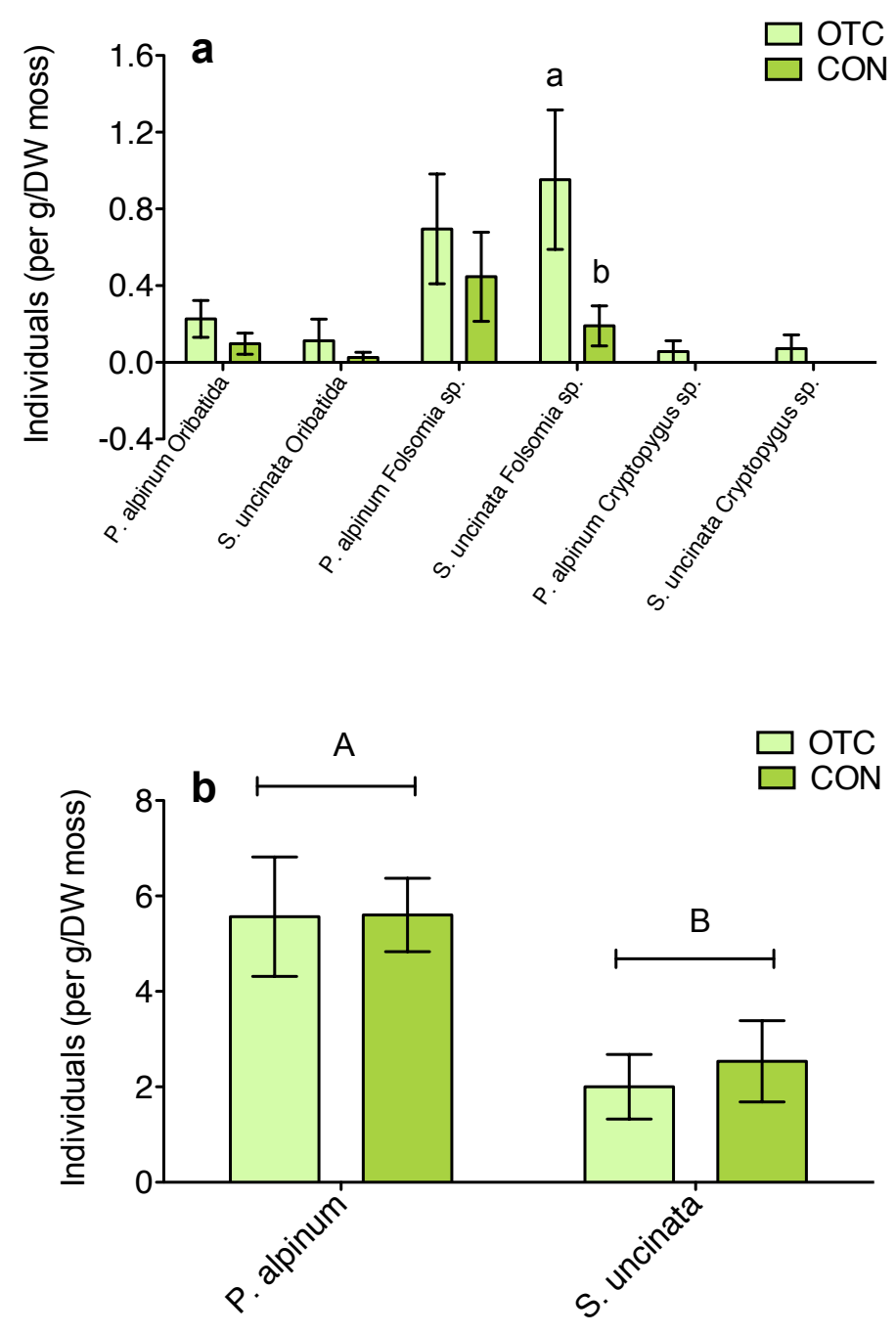


\section{Chapter 5}

\section{Conclusion}

This dissertation work contains a large and diverse contribution, which furthers our understanding of the wide-reaching impacts of human activities on the ecology and biodiversity of epiphytic lichen and moss communities. Non-vascular epiphytes (lichens and mosses) are seemingly small and fairly inconspicuous on the landscape, yet remarkably they occur on nearly every terrestrial ecosystem on the globe (Elbert et al. 2012) and are profoundly important for their influence on associated and adjacent biota and whole-system processes (e.g. hydrology, mineral cycling, food web energetics) (Cornelissen et al. 2007, Ellis 2012). Worldwide, communities of lichens and mosses occupy a number of diverse habitats - from urban to pristine, cold to hot, dry to wet - yet epiphyte communities are among the most threatened and sensitive of ecological guilds at risk of human-related impacts (Goward and Arsenault 2000, Ozanne et al. 2003, Ellis et al. 2011, Ellis 2012). While human impacts continue to span the globe, we anticipate significant changes to occur for lichen and moss community structure and associated ecosystem processes, the magnitude of which is largely unknown. This collective dissertation work is both timely and pertinent in the face of an rapidly emerging area of global research which explores human consequences on global epiphyte ecology (Cornelissen et al. 2007, Zotz and Bader 2009, Elmendorf et al. 2012, He et al. 2016).

In chapter two, I revisited a historic urban lichen community study to assess how urban lichen communities have responded to changes in regional air quality occurring over the last nearly two decades. I further comprehensively investigated the biodiversity 
of urban arboreal lichen communities in a native coniferous tree species, Pseudotsuga menziesii, at sites within the larger urban study. Despite rapid population growth in the Pacific Northwest, relatively little is known about how human activities affect urban tree biology and more specifically how urbanization impacts tall tree canopy epiphyte communities, a unique and sensitive component of Pacific Northwest tree canopies, known to contribute a number of essential ecosystem functions. I found that urban parks and forested areas can harbor a species rich community of lichens epiphytes and that such biodiversity has been sustained over and 18-year time period in the urban area of Portland, OR. Measures of biodiversity are important indicators for environmental assessment, however a critical limitation of many biodiversity indices is that community composition and functional biodiversity are not always interpretable. Further, I found evidence for the distinct homogenization of urban epiphytic lichen communities, suggesting that expanding beyond simplistic measures of biodiversity to consider community composition and functional biodiversity may be necessary when assesesing the ecology and potential ecosystem services of epiphyte communites within urbanizing landscapes.

I expanded upon these findings in chapter three, where I present the first tall tree canopy study across a regional gradient of urbanization near Portland, Oregon, USA. I found that tall tree canopy epiphyte communities change dramatically along regional gradients of urbanization, most notably by the transitioning of species $\mathrm{N}$ functional groups from sensitive, oligotrophic species to a dominance of urban-tolerant, eutrophic species, tracking with published results from other PNW regional ground-based studies. The implications these dramatic shifts in species composition have on essential PNW 
ecosystem processes, like $\mathrm{N}$-fixation and canopy microclimate regulation, is still not well understood and difficult to conduct ecosystem-scale projects to formally evaluate. However, we find strong evidence that native conifer trees in urban areas may provide a diversity of essential ecosystem services, including providing stratified habitat for epiphyte communities and their associated microarthropod communities and the scavenging of excess atmospherically deposited nutrients. Future work is needed to understand how losses in canopy $\mathrm{N}$ fixation and species with large biomass (both lichens and bryophytes) will affect nutrient and hydrologic cycling in the PNW region, which continue to undergo rapid growth and urbanization.

These two studies could benefit from a more comprehensive gradient study design for both ground and tree canopy to test ideas regarding human costs and benefits of changing urban canopy epiphyte communites (e.g. metal and nutrient sequestration) and ecosystem impacts from altered canopy epiphyte communites (e.g. canopy hydrology, microclimate, tree health, nitrogen fixation, structuring of canopy-dwelling microfauna). Further, municipal managers could use these findings to support the preservation and intentional planting of urban trees and urban forest patches which facilitate and preserve epiphyte biodiversity. Future directions for this work could exapnd on study areas to the larger Pacific Northwest area to include areas of Seattle, Washington or by expandng Internationally to areas of South America with similar continental wind flows and air pollution patterns to provide better context for widespread urbanization impacts on canopy-dwelling epiphyte communites.

In chapter four I investigated the impacts of passive warming by Open Top Chambers (OTCs) in moss-dominated ecosystems located on the Western Antarctic 
Peninsula, an area of increasing climate warming. I compared species-specific temperature effects, moss canopy morphology, sexual reproductive effort and invertebrate communities between OTC and control moss communities for two moss species, Polytrichastrum alpinum and Sanionia uncinata, that make up over $65 \%$ of the terrestrial vegetative cover in the area. I found distinct reproductive shifts in P. alpinum under passive warming compared to controls. Moss communities under warming also had substantially larger total invertebrate communities than those in control moss communities, and invertebrate communities were significantly affected by moss species and moss reproductive effort. Further, substantial species-specific thermal differences among contiguous patches of these dominant moss species were revealed. These results suggest that continued warming will differentially impact the reproductive output of Antarctic moss species and is likely to dramatically alter terrestrial ecosystems dynamics from the bottom up. While climate amelioration in the Antarctic is thought to generate positive responses from terrestrial biota, collective research suggests the responses will likely be subtle, yet lead to distinct and great consequences for communities and ecosystems.

Future directions for this work will expand on the hypothesized reproductive barriers for mosses and extend further to examine the full spectrum of fungal and microbial communities in soils and moss canopies under passive warming, connecting the fungal and microbial patterns with patterns observed in invertebrate communities, identifying the role of mosses in structuring Antarctic terrestrial food-webs. A separate analysis of soil and moss communities will also inform the dynamics of soil and moss 
canopy dwelling invertebrates and provide more information to understand the facilitation of mosses in soil ecology and processes of terrestrialization.

The opening remarks of Science magazine's article on Human-Dominated Ecosystems (Gallagher and Carpenter 1997) said, "Ecologists traditionally have sought to study pristine ecosystems to try to get at the workings of nature without the confounding influences of human activity. But that approach is collapsing in the wake of scientists' realization that there are no places left on Earth that don't fall under humanity's shadow." The combined studies presented here, illustrate broadly the range of biological and ecological responses lichen and moss communities will have to human activities, and further highlight that human impacts are occurring for epiphyte communities across the globe, from the tree canopies of the Pacific Northwest to the polar landscape of Antarctica. To better understand the magnitude these changes will have on resulting ecosystem processes and dynamics requires continued work in this emerging area of research. 


\section{References}

ACIA. 2005. Arctic Climate Impact Assessment. Cambridge, UK.

Antoine, M. E. 2004. An Ecophysiological Approach to Quantifying Nitrogen Fixation by Lobaria oregana. The Bryologist 107:82-87.

Bačkor, M., O. Peksa, P. Škaloud, and M. Bačkorová. 2010. Photobiont diversity in lichens from metal-rich substrata based on ITS rDNA sequences. Ecotoxicology and Environmental Safety 73:603-612.

Barcikowski, A., and P. . Loro. 1999. Changes in chlorophyll content thoughout the year in selected species of mosses on King George Island, South Shetland Islands, maritime Antarctic. Polish Polar Research 20:291-299.

Di Battista, T., F. Fortuna, and F. Maturo. 2016. Environmental monitoring through functional biodiversity tools. Ecological Indicators 60:237-247.

Berg, T., O. Royset, and E. Steinnes. 1995. Moss (Hylocomium splendens) used as biomonitor of atmospheric trace element deposition: Estimation of uptake efficiencies. Atmospheric Environment 29:353-360.

Berryman, S., and B. McCune. 2006. Estimating epiphytic macrolichen biomass from topography, stand structure and lichen community data. Journal of Vegetation Science 17:157.

Binkley, D., and R. L. Graham. 1981. Biomass, Production, and Nutrient Cycling of Mosses in an Old-Growth Douglas-Fir Forest. Ecology 62:1387-1389.

Bokhorst, S., P. Convey, A. Huiskes, and R. Aerts. 2015. Usnea antarctica, an important Antarctic lichen, is vulnerable to aspects of regional environmental change. Polar Biology.

Bokhorst, S., A. Huiskes, P. Convey, and R. Aerts. 2007. The effect of environmental change on vascular plant and cryptogam communities from the Falkland Islands and the Maritime Antarctic. BMC Ecology 7:15.

Bokhorst, S., A. Huiskes, P. Convey, P. M. van Bodegom, and R. Aerts. 2008. Climate change effects on soil arthropod communities from the Falkland Islands and the Maritime Antarctic. Soil Biology and Biochemistry 40:1547-1556.

Bokhorst, S., A. Huiskes, P. Convey, B. Van De Vijver, and D. H. Wall. 2011. Microclimate impacts of passive warming methods in Antarctica : implications for climate change studies:1421-1435.

Botting, R. S., J. Campbell, and A. L. Fredeen. 2008. Contrasting Arboreal and Terrestrial Macrolichen and Bryophyte Communities in Old-Growth Sub-Boreal Spruce Forests of Central British Columbia. The Bryologist 111:607-619.

Bowker, M. A., L. R. Stark, D. N. McLetchie, and B. D. Mishler. 2000. Sex expression, skewed sex ratios, and microhabitat distribution in the dioecious desert moss Syntrichia caninervis (Pottiaceae). American Journal of Botany 87:517-526.

Buczkowski, G., and D. S. Richmond. 2012. The effect of urbanization on ant abundance and diversity: a temporal examination of factors affecting biodiversity. PloS one 7:e41729.

Campbell, J., and A. L. Fredeen. 2004. Lobaria pulmonaria abundance as an indicator of macrolichen diversity in Interior Cedar - Hemlock forests of east-central British Columbia. Canadian Journal of Botany 82:970-982. 
Casanova-Katny, A., and L. A. Cavieres. 2012. Antarctic moss carpets facilitate growth of Deschampsia antarctica but not its survival. Polar Biology 35:1869-1878.

Casanova-Katny, A., G. A. Torres-Mellado, and S. M. Eppley. 2016. Reproductive output of mosses under experimental warming on Fildes Peninsula, King George Island, maritime Antarctica. Revista Chilena de Historia Natural 89:13.

Chapin, F. S., E. S. Zavaleta, V. T. Eviner, R. L. Naylor, P. M. Vitousek, H. L. Reynolds, D. U. Hooper, S. Lavorel, O. E. Sala, S. E. Hobbie, M. C. Mack, and S. Díaz. 2000. Consequences of changing biodiversity. Nature 405:234-42.

Chown, S. L., A. Clarke, C. I. Fraser, S. C. Cary, K. L. Moon, and M. A. McGeoch. 2015. The changing form of Antarctic biodiversity. Nature 522:431-438.

Clavel, J., R. Julliard, and V. Devictor. 2011. Worldwide decline of specialist species: Toward a global functional homogenization? Frontiers in Ecology and the Environment 9:222-228.

Clement, J. P., and D. C. Shaw. 1999. Crown structure and the distribution of epiphyte functional group biomass in old-growth Pseudosuga menziesii trees. Ecoscience 6:243-254.

Concepción, E. D., M. Moretti, F. Altermatt, M. P. Nobis, and M. K. Obrist. 2015. Impacts of urbanisation on biodiversity: The role of species mobility, degree of specialisation and spatial scale. Oikos:1571-1582.

Convey, P. 1994a. Photosynthesis and dark respiration in Antarctic mosses - an initial comparative study. Polar Biology 14:65-69.

Convey, P. 1994b. Modelling reproductive effort in sub- and maritime Antarctica mosses. International Association for Ecology 100:45-53.

Convey, P. 1996a. Overwintering strategies of terrestrial invertebrates in Antarctica - The significance of flexibility in extremely seasonal environments.

Convey, P. 1996b. THE INFLUENCE OF ENVIRONMENTAL CHARACTERISTICS ON LIFE HISTORY ATTRIBUTES OF ANTARCTIC TERRESTRIAL BIOTA. Biological Reviews 71:191-225.

Convey, P. 2011. Antarctic terrestrial biodiversity in a changing world. Polar Biology 34:1629-1641.

Convey, P., R. Bindschadler, G. DiPrisco, E. Fahrbach, J. Gutt, D. D. . Hodgson, P. Mayewski, C. C. P. Summerhayes, J. Turner, ACCE, G. Di Prisco, E. Fahrbach, J. Gutt, D. D. . Hodgson, P. Mayewski, C. C. P. Summerhayes, J. Turner, and ACCE Consortium. 2009. Antarctic climate change and the environment. Antarctic Science 21:541-563.

Convey, P., S. L. Chown, A. Clarke, D. K. A. Barnes, S. Bokhorst, V. Cummings, H. W. Ducklow, F. Frati, T. G. A. Green, S. Gordon, H. J. Griffiths, C. Howard-Williams, A. H. L. Huiskes, J. Laybourn-Parry, W. B. Lyons, A. McMinn, S. A. Morley, L. S. Peck, A. Quesada, S. A. Robinson, S. Schiaparelli, and D. H. Wall. 2014. The spatial structure of antarctic biodiversity. Ecological Monographs 84:203-244.

Convey, P., P. Pugh, C. Jackson, A. Murray, C. Ruhland, F. Xiong, and T. Day. 2002. Response of Antarctic Terrestrial Microarthropods To Long-Term Climate Manipulations. Ecology 83:3130-3140.

Convey, P., and R. I. . Smith. 2006. Responses of terrestrial Antarctic ecoystems to climate change. Pages 1-12Plants and Climate Change. 41st edition. Springer 
Netherlands.

Convey, P., and R. I. L. Smith. 1993a. Investment in Sexual Reproduction by Antarctic Mosses. Oikos 68:293-302.

Convey, P., and R. I. L. Smith. 1993b. Investment in Sexual Reproduction by Anatarctic Mosses. Nordic Socitey Oikos 68:293-302.

Cornelissen, J. H. C., S. I. Lang, N. A. Soudzilovskaia, and H. J. During. 2007. Comparative cryptogam ecology: a review of bryophyte and lichen traits that drive biogeochemistry. Annals of botany 99:987-1001.

Coxson, D. S., and N. M. Nadkarni. 1995. Ecological roles of epiphytes in nutrient cycles of forest ecosystems. Pages 495-543in M. D. Lowman and N. M. Nadkarni, editors.Forest Canopies. Academic Press, Incorporated.

Cronberg, N., R. Natcheva, and K. Hedlund. 2006. Microarthropods Mediate Sperm Transfer in Mosses. Science 313:1255.

Davey, M. C., and P. Rothery. 1997. Interspecific variation in respiratory and photosynthetic parameters in Antarctic bryophytes. New Phytologist 137:231-240.

Davies, L., J. W. Bates, J. N. B. Bell, P. W. James, and O. W. Purvis. 2007. Diversity and sensitivity of epiphytes to oxides of nitrogen in London. Environmental pollution (Barking, Essex : 1987) 146:299-310.

Day, T. A., C. T. Ruhland, S. L. Strauss, J. H. Park, M. L. Krieg, M. A. Krna, and D. M. Bryant. 2009. Response of plants and the dominant microarthropod, Cryptopygus antarcticus, to warming and contrasting precipitation regimes in Antarctic tundra. Global Change Biology 15:1640-1651.

Deguines, N., R. Julliard, M. de Flores, and C. Fontaine. 2016. Functional homogenization of flower visitor communities with urbanization. Ecology and Evolution 6:1967-1976.

DellaSala, D. a., P. Brandt, M. Koopman, J. Leonard, C. Meisch, P. Herzog, P. Alaback, M. I. Goldstein, S. Jovan, a. MacKinnon, and H. von Wehrden. 2015. Climate Change May Trigger Broad Shifts in North America's Pacific Coastal Rainforests. Reference Module in Earth Systems and Environmental Sciences:1-12.

DeLuca, T. H., O. Zackrisson, M.-C. Nilsson, and A. Sellstedt. 2002. Quantifying nitrogen-fixation in feather moss carpets of boreal forests. Nature 419:917-919.

Denison, W.C. and Carpenter, S. M. 1973. A Guide to Air Quality Monitoring with Lichens.

Denison, W. C. 1979. Lobaria oregana, a nitrogen-fixing lichen in old-growth Douglas fir forests. Pages 266-275in C. T. W. \& D. A. P. (eds. . J. C. Gordon, editor.Symbiotic nitrogen fixation in the management of temperate forests. Oregon State University Forest Research Laboratory, Corvallis, Oregon.

Donovan, G. H., S. E. Jovan, D. Gatziolis, I. Burstyn, Y. L. Michael, and V. J. Monleon. 2016. Using an epiphytic moss to identify previously unknown sources of atmospheric cadmium pollution. Science of the Total Environment 559:84-93.

Elbert, W., B. Weber, S. Burrows, J. Steinkamp, B. Büdel, M. O. Andreae, and U. Pöschl. 2012. Contribution of cryptogamic covers to the global cycles of carbon and nitrogen. Nature Geoscience 5:459-462.

Ellis, C. J. 2012. Lichen epiphyte diversity: A species, community and trait-based review. Perspectives in Plant Ecology, Evolution and Systematics 14:131-152. 
Ellis, C. J., R. Yahr, and B. J. Coppins. 2011. Archaeobotanical evidence for a massive loss of epiphyte species richness during industrialization in southern England. Proceedings. Biological sciences / The Royal Society 278:3482-9.

Elmendorf, S. C., G. H. R. Henry, R. D. Hollister, R. G. Björk, A. D. Bjorkman, T. V. Callaghan, L. S. Collier, E. J. Cooper, J. H. C. Cornelissen, T. A. Day, A. M. Fosaa, W. A. Gould, J. Grétarsdóttir, J. Harte, L. Hermanutz, D. S. Hik, A. Hofgaard, F. Jarrad, I. S. Jónsdóttir, F. Keuper, K. Klanderud, J. A. Klein, S. Koh, G. Kudo, S. I. Lang, V. Loewen, J. L. May, J. Mercado, A. Michelsen, U. Molau, I. H. MyersSmith, S. F. Oberbauer, S. Pieper, E. Post, C. Rixen, C. H. Robinson, N. M. Schmidt, G. R. Shaver, A. Stenström, A. Tolvanen, Ø. Totland, T. Troxler, C. H. Wahren, P. J. Webber, J. M. Welker, and P. A. Wookey. 2012. Global assessment of experimental climate warming on tundra vegetation: Heterogeneity over space and time. Ecology Letters 15:164-175.

Eppley, S. M., T. N. Rosenstiel, C. B. Graves, and E. L. García. 2011. Limits to Sexual Reproduction in Geothermal Bryophytes. International Journal of Plant Sciences 172:870-878.

Fenn, M. E., J. S. Baron, E. B. Allen, H. M. Reuth, K. R. Nydick, L. Geiser, W. D. Bowman, J. O. Sickman, T. Meixner, D. W. Johnson, and P. Neitlich. 2003a. Ecological Effects of Nitrogen deposition in the Western United States. Bioscience 53.

Fenn, M. E., R. Haeuber, G. S. Tonnesen, J. S. Baron, S. Grossman-clarke, D. Hope, D. A. J. E, S. Copeland, L. G. Er, H. M. Rueth, J. O. Sickman, D. A. Jaffe, S. Copeland, L. Geiser, H. M. Rueth, and J. O. Sickman. 2003b. Nitrogen Emissions, Deposition, and Monitoring in the Western United States. BioScience 53:391-403.

Fenn, M. E., C. S. Ross, S. L. Schilling, W. D. Baccus, M. a. Larrabee, and R. a. Lofgren. 2013. Atmospheric deposition of nitrogen and sulfur and preferential canopy consumption of nitrate in forests of the Pacific Northwest, USA. Forest Ecology and Management 302:240-253.

Fisher, J. P., C. Estop-Aragonés, A. Thierry, D. J. Charman, S. A. Wolfe, I. P. Hartley, J. B. Murton, M. Williams, and G. K. Phoenix. 2016. The influence of vegetation and soil characteristics on active-layer thickness of permafrost soils in boreal forest. Global Change Biology 22:3127-3140.

Freiberg, M. 2001. The influence of epiphyte cover on branch temperature in a tropical tree. Plant Ecology 153:241-250.

Gallagher, R., and B. Carpenter. 1997. Human-Dominated Ecosystems. Science 277:485.

Gauslaa, Y., and D. Coxson. 2011. Interspecific and intraspecific variations in water storage in epiphytic old forest foliose lichens. Botany 89:787-798.

Gauslaa, Y., D. S. Coxson, and K. A. Solhaug. 2012. The paradox of higher light tolerance during desiccation in rare old forest cyanolichens than in more widespread co-occurring chloro- and cephalolichens. New Phytologist 195:812-822.

Geiser, L. H. 2004. Monitoring Air Quality Using Lichens on National Forests of the Pacific Northwest: Methods and Strategy. USDA- Forest Service Pacific Northwest Regional Technical Paper:134.

Geiser, L. H., S. E. Jovan, D. A. Glavich, and M. K. Porter. 2010. Lichen-based critical loads for atmospheric nitrogen deposition in Western Oregon and Washington 
Forests, USA. Environmental Pollution 158:2412-2421.

Geiser, L. H., and P. N. Neitlich. 2007. Air pollution and climate gradients in western Oregon and Washington indicated by epiphytic macrolichens. Environmental pollution (Barking, Essex : 1987) 145:203-18.

George, L. A., J. Parra, and P. Sitbon. 2005. Horizons - Portland Area Real-Time and Archived Air Quality and Meterological Data. http://www.horizons.pdx.edu/index.php.

Goudie, A. 2000. The Human Impact on the Natural Environment. MIT Press.

Goward, T. 2010. Twelve Readings on the Lichen Thallus XII. Formal Propositions. Evansia 29:28-49.

Goward, T., and A. Arsenault. 2000. Cyanolichens and conifers : implications for global conservation. Forest Snow and Landscape Research 75:303-318.

Graph Pad Prism. 2007. . GraphPad Software, La Jolla, CA.

Grenon, J. A. 2012. Epiphytic Lichens, Nitrogen Deposition and Climate in the US Northern Rocky Mountain States. Montana State University.

Guénard, B., A. Cardinal-De Casas, and R. R. Dunn. 2014. High diversity in an urban habitat: are some animal assemblages resilient to long-term anthropogenic change? Urban Ecosystems:449-463.

Harmens, H., D. a. Norris, G. R. Koerber, A. Buse, E. Steinnes, and Å. Rühling. 2008. Temporal trends (1990-2000) in the concentration of cadmium, lead and mercury in mosses across Europe. Environmental Pollution 151:368-376.

He, X., K. S. He, and J. Hyvönen. 2016. Will bryophytes survive in a warming world? Perspectives in Plant Ecology, Evolution and Systematics 19:49-60.

Van Herk, C. M., E. a M. Mathijssen-Spiekman, and D. De Zwart. 2003. Long distance nitrogen air pollution effects on lichens in Europe. Lichenologist 35:347-359.

Hillebrand, H., and B. Matthiessen. 2009. Biodiversity in a complex world: consolidation and progress in functional biodiversity research. Ecology letters 12:1405-19.

IPCC. 2014. Climate Change 2014: Mitigation of Climate Change.

Jovan, S. 2008. Lichen Bioindication of Biodiversity, Air Quality, and Climate: Baseline Results From Monitoring in Washington, Oregon, and California. Page USDA Forest Service General Technical Report PNW-GTR-737.

Jovan, S., and B. McCune. 2005. Air-quality bioindication in the greater central valley of California, with epiphytic macrolichen communities. Ecological Appliations 15:1712-1726.

Jovan, S., J. Riddell, P. Padgett, and T. H. Nash III. 2012. Eutrophic lichens respond to multiple forms of $\mathrm{N}$ : implications for critical levels and critical loads research. Ecological Applications 22:1910-1922.

Kappen, L. 1993. Plant Activity under Snow and Ice, with Particular Reference to Lichens. Arctic 46:297-302.

Klopatek, J. M., M. J. Barry, and D. W. Johns-. 2006. Potential canopy interception of nitrogen in the Pacific Northwest, USA. Forest Ecology and Management 234:344354.

Knops, J. M. H. H., T. H. Nash III, and W. H. Schlesinger. 1996. The influence of epiphytic lichens on the nutrient cycling of a blue oak woodland. Ecological Monographs 66:75-82. 
Knops, J. M. H., T. H. Nash III, V. L. Boucher, and W. H. Schlesinger. 1991. Mineral Cycling and Epiphytic Lichens: Implications at the Ecosystem Level. The Lichenologist 23:309-321.

Kowarik, I. 2011. Novel urban ecosystems, biodiversity, and conservation. Environmental pollution (Barking, Essex : 1987) 159:1974-83.

Lagerström, A., M. C. Nilsson, O. Zackrisson, and D. A. Wardle. 2007. Ecosystem input of nitrogen through biological fixation in feather mosses during ecosystem retrogression. Functional Ecology 21:1027-1033.

Lavian, I. L., V. S., B. G., and S. Y. 2001. Soil microbial community and bacterial functional diversity at Machu Picchu, King George Island, Antarctica. Polar Biology 24:411-416.

Lewis Smith, R., and P. Convey. 2002. Enhanced sexual reproduction in bryophytes at high latitudes in the maritime Antarctic. Journal of Bryology 24.

Lindo, Z., and A. Gonzalez. 2010. The Bryosphere: An Integral and Influential Component of the Earth's Biosphere. Ecosystems 13:612-627.

Lindo, Z., and J. A. Whiteley. 2011. Old trees contribute bio-available nitrogen through canopy bryophytes. Plant and Soil 342:141-148.

Lindo, Z., and N. Winchester. 2013. Out on a limb: Microarthropod and microclimate variation in coastal temperate rainforest canopies. Insect Conservation and Diversity 6:513-521.

Longton, R. E. 1997. The role of bryophytes and lichens in polar ecosystems. Page 294in S. J. Woodin and M. Marquiss, editors.Ecology of Arctic Environments: 13th Special Symposium of the British Ecological Society. Cambridge University Press.

Marshall, W. ., and P. Convey. 1997. Dispersal of moss propagules on Signy Island, maritime Antarctic. Polar Biology 18:376-383.

McCune, B. 1993. Gradients in Epiphyte Biomass in Three Pseudotsuga- Tsuga Forests of Different Ages in Western Oregon and Washington. The Bryologist 96:405-411.

McCune, B. 1994. Using Epiphyte Litter to Estimate Epiphyte Biomass. The Bryologist 97:396-401.

McCune, B. 2000. Lichen Communities as Indicators of Forest Health New Frontiers in Bryology and Lichenology. The Bryologist 103:353-356.

McCune, B., K. A. Amsberry, F. J. Camacho, C. Emerson, G. Felder, P. French, D. Greene, E. B. Peterson, K. Pendergrass, G. G. Parker, M. Hutten, B. Larson, M. Lesko, S. Maiors, T. Peterson, J. Platt, J. Proctor, T. Rambo, A. Rosso, R. Turner, and M. Widmer. 1997. Vertical Profile of Epiphytes in a Pacific Northwest Oldgrowth Forest. Northwest Science 71:145-152.

Mccune, B., J. P. Dey, J. E. Peck, D. Cassell, K. Heiman, S. Will-wolf, and P. N. Neitlich. 1997. Repeatability of Community Data: Species Richness versus Gradient Scores in Large-Scale Lichen Studies. The Bryologist 100:40-46.

McCune, B., and L. H. Geiser. 2003. Macrolichens of the Pacific Northwest. 2nd edition. Oregon State University Press.

McKinney, M. L. 2006. Urbanization as a major cause of biotic homogenization. Biological Conservation 127:247-260.

McKinney, M. L., and J. L. Lockwood. 1999. Biotic homogenization: A few winners replacing many losers in the next mass extinction. Trends in Ecology and Evolution 
14:450-453.

Merinero, S., O. Hilmo, and Y. Gauslaa. 2014. Size is a main driver for hydration traits in cyano- and cephalolichens of boreal rainforest canopies. Fungal Ecology 7:59-66.

Millbank JW. 1982. The Assessment of Nitrogen Fixation and Throughput by Lichens . III . Losses of Nitrogenous Compounds by Peltigera membranacea , p . polydactyla and Lobaria pulmonaria in Simulated Rainfall Episodes Author ( s ): J . W .

Millbank Source: The New Phytolog. New Phytologist 92:229-234.

Millennium Ecosystem Assessment. 2005. Ecosystems and Human Well-being: current State and Trends. Findings of the Condition and Trends Working Group.

Washington D.C. USA.

Mouratov, S., I. Lahav, G. Barness, and Y. Steinberger. 2001. Preliminary study of the soil nematode community at Machu Picchu Station, King George Island, Antarctica. Polar Biology 24:545-548.

Munzi, S., T. Pisani, L. Paoli, M. Renzi, and S. Loppi. 2013. Effect of nitrogen supply on the $\mathrm{C} / \mathrm{N}$ balance in the lichen Evernia prunastri (L.) Ach. Turkish Journal of Biology 37:165-170.

Naeem, S., F. S. Chapin III, R. Costanza, P. R. Ehrlich, F. B. Golley, D. U. Hooper, J. H. Lawton, R. V. O’Neil, H. A. Mooney, O. E. Sala, A. J. Symstad, and D. Tilman. 1999. Biodiversity and Ecosystem Functioning: Maintaining Natural Life Support Processes. Issues in Ecology 4:2-11.

Nakatsubo, T. 2002. Predicting the impact of climatic warming on the carbon balance of the moss Sanionia uncinata on a maritime Antarctic island. Journal of Plant Research 115:99-106.

Nielsen, A. B., M. van den Bosch, S. Maruthaveeran, and C. Konijnendijk van den Bosch. 2014. Species richness in urban parks and its drivers: A review of empirical evidence. Urban Ecosystems 17:305-327.

Nielsen, U. N., and D. H. Wall. 2013. The future of soil invertebrate communities in polar regions: Different climate change responses in the Arctic and Antarctic? Ecology Letters 16:409-419.

Ochyra, R. 1998. The Moss Flora of King George Island, Antarctica. Page (W. Szafer Institute of Botany, Ed.). Polish Academy of Sciences, Antarctica.

Oksanen, A. J., F. G. Blanchet, R. Kindt, P. R. Minchin, R. B. O. Hara, G. L. Simpson, P. Soly-, M. H. H. Stevens, and H. Wagner. 2011. vegan: Community Ecology Package.

Ordóñez, C., and P. N. Duinker. 2012. Ecological integrity in urban forests. Urban Ecosystems 15:863-877.

Ozanne, C. M. P., D. Anhuf, S. L. Boulter, M. Keller, R. L. Kitching, C. Körner, F. C. Meinzer, a W. Mitchell, T. Nakashizuka, P. L. S. Dias, N. E. Stork, S. J. Wright, and M. Yoshimura. 2003. Biodiversity meets the atmosphere: a global view of forest canopies. Science (New York, N.Y.) 301:183-6.

ParkScore. 2016. . http://parkscore.tpl.org/city.php?city=Portland.

Parmesan, C. 2006. Ecological and Evolutionary Responses to Recent Climate Change. Http://Dx.Doi.Org/10.1146/Annurev.Ecolsys.37.091305.110100 37:637-669.

Peck, J. E., and B. McCune. 1997. Remnant trees and canopy lichen communities in Western Oregon: A retrospective approach. Ecological Applications 7:1181-1187. 
Pereira, H. M., P. W. Leadley, V. Proença, R. Alkemade, J. P. W. Scharlemann, J. F. Fernandez-Manjarrés, M. B. Araújo, P. Balvanera, R. Biggs, W. W. L. Cheung, L. Chini, H. D. Cooper, E. L. Gilman, S. Guénette, G. C. Hurtt, H. P. Huntington, G. M. Mace, T. Oberdorff, C. Revenga, P. Rodrigues, R. J. Scholes, U. R. Sumaila, and M. Walpole. 2010. Scenarios for global biodiversity in the 21 st century. Science 330:1496-501.

Perlmutter, G. B. 2010. Bioassessing air pollution effects with epiphytic lichens in Raleigh, North Carolina, U.S.A. The Bryologist 113:39-50.

Pettersson, R. B., J. P. Ball, K.-E. Renhorn, P.-A. Esseen, and K. Sjoberg. 1995. Invertebrate communities in boreal forest canopies as influenced by forestry and lichens with implications for passerine birds. Biological Conservation 74:57-63.

Pike, L. H. 1978. The Importance of Epiphytic Lichens in Mineral Cycling. The Bryologist 81:247-257.

Pike, L. H., R. a. Rydell, and W. C. Denison. 1977. A 400-year-old Douglas fir tree and its epiphytes: biomass, surface area, and their distributions.

Pinho, P., O. Correia, M. Lecoq, S. Munzi, S. Vasconcelos, P. Gonçalves, R. Rebelo, C. Antunes, P. Silva, C. Freitas, N. Lopes, M. Santos-reis, and C. Branquinho. 2016. Evaluating green infrastructure in urban environments using a multi-taxa and functional diversity approach. Environmental Research 147:601-610.

Porada, P., A. Ekici, and C. Beer. 2016. Effects of bryophyte and lichen cover on permafrost soil temperature at large scale. Cryosphere 10:2291-2315.

Porada, P., B. Weber, W. Elbert, U. Pöschl, and A. Kleidon. 2013. Estimating global carbon uptake by lichens and bryophytes with a process-based model. Biogeosciences Discussions 10:3735-3847.

Porada, P., B. Weber, W. Elbert, U. Pöschl, and A. Kleidon. 2014. Estimating impacts of lichens and bryophytes on global biogeochemical cycles. Global Biogeochemical Cycles 28:71-85.

Post, E., M. C. Forchhammer, M. S. Bret-Harte, T. V Callaghan, T. R. Christensen, B. Elberling, A. D. Fox, O. Gilg, D. S. Hik, T. T. Høye, R. a Ims, E. Jeppesen, D. R. Klein, J. Madsen, a D. McGuire, S. Rysgaard, D. E. Schindler, I. Stirling, M. P. Tamstorf, N. J. C. Tyler, R. van der Wal, J. Welker, P. a Wookey, N. M. Schmidt, and P. Aastrup. 2009. Ecological dynamics across the Arctic associated with recent climate change. Science (New York, N.Y.) 325:1355-1358.

Prescott, C. E. 2002. The influence of the forest canopy on nutrient cycling. Tree physiology 22:1193-200.

Pugh, P. J. A., and P. Convey. 2008. Surviving out in the cold : Antarctic endemic invertebrates and their refugia:2176-2186.

Pypker, T. G., M. H. Unsworth, and B. J. Bond. 2006. The role of epiphytes in rainfall interception by forests in the Pacific Northwest . I . Laboratory measurements of water storage. Canadian Journal of Forest Research 36:809-818.

Rao, M., L. A. George, T. N. Rosenstiel, V. Shandas, and A. Dinno. 2014. Assessing the relationship among urban trees, nitrogen dioxide, and respiratory health. Environmental Pollution 194:96-104.

Robinson, S. a, J. Wasley, and A. K. Tobin. 2003. Living on the edge - plants and global change in continental and maritime Antarctica. Global Change Biology 9:1681- 
1717.

Root, H. T., L. H. Geiser, M. E. Fenn, S. Jovan, M. a. Hutten, S. Ahuja, K. Dillman, D. Schirokauer, S. Berryman, and J. a. Mcmurray. 2013. A simple tool for estimating throughfall nitrogen deposition in forests of western North America using lichens. Forest Ecology and Management 306:1-8.

Root, H. T., L. H. Geiser, S. Jovan, and P. Neitlich. 2015. Epiphytic macrolichen indication of air quality and climate in interior forested mountains of the Pacific Northwest, USA. Ecological Indicators 53:95-105.

Root, H. T., G. G. McGee, and R. a. Norton. 2007. Arboreal Mite Communities on Epiphytic Lichens of the Adirondack Mountains of New York. Northeastern Naturalist 14:425-438.

Rosenstiel, T. N., E. E. Shortlidge, A. N. Melnychenko, J. F. Pankow, and S. M. Eppley. 2012. Sex-specific volatile compounds influence microarthropod-mediated fertilization of moss. Nature 489:431-433.

RStudio Team. 2015. . RStudio: Integrated Development for R. RStudio, Inc., Boston, MA.

Rydgren, K., N. Cronberg, and R. H. Økland. 2006. Factors influencing reproductive success in the clonal moss, Hylocomium splendens. Oecologia 147:445-454.

Seto, K. C., B. Guneralp, and L. R. Hutyra. 2012. Global forecasts of urban expansion to 2030 and direct impacts on biodiversity and carbon pools. Proceedings of the National Academy of Sciences 109:16083-16088.

Shortlidge, E. E., S. M. Eppley, H. Kohler, T. N. Rosenstiel, G. E. Zúñiga, and A. Casanova-Katny. 2016. Passive warming reduces stress and shifts reproductive effort in the Antarctic moss, Polytrichastrum alpinum. Annals of botany.

Siepel, H. 1996. The Importance of Unpredictable and Short-Term Environmental Extremes for Biodiversity in Oribatid Mites. Biodiversity Letters 3:26-34.

Sigal, L. L., and T. H. Nash III. 1983. Lichen Communities on Conifers in Southern California Mountains : An Ecological Survey Relative to Oxidant Air Pollution. Ecology 64:1343-1354.

Sillett, S. C., B. McCune, J. . Peck, and T. R. Rambo. 2000a. Four Years of Epiphyte Colonization in Douglas-fir Forest Canopies. The Bryologist 103:661-669.

Sillett, S. C., B. McCune, J. E. Peck, T. R. Rambo, and A. Ruchty. 2000b. Dispersal limitation of epiphytic lichens result in species dependent on old-growth forests. Ecological Appliations 10:789-799.

Sillett, S. C., and T. R. Rambo. 2000. Vertical Distribution of Dominant Epiphytes in Douglas-Fir Forests of the Central Oregon Cascades. Northwest Science 74:44-49.

Smith, R. 2005a. The bryophyte flora of geothermal habitats on Deception Island, Anatarctica. Journal of the Hattori Botanical Laboratory 97:233-248.

Smith, V. R. 2005b. Moisture, carbon and inorganic nutrient controls of soil respiration at a sub-Antarctic island. Soil Biology and Biochemistry 37:81-91.

Sollins, P., C. Grier, F. McCorison, K. Cormack, Jr, R. Fogel, and R. Fredriksen. 1980. The Internal Element Cycles of an Old-Growth Douglas-Fir Ecosystem in Western Oregon. Ecological Monographs 50:261-285.

Soudzilovskaia, N. A., P. M. van Bodegom, and J. H. C. Cornelissen. 2013. Dominant bryophyte control over high-latitude soil temperature fluctuations predicted by heat 
transfer traits, field moisture regime and laws of thermal insulation. Functional Ecology 27:1442-1454.

Stanton, D. E., J. Huallpa Chávez, L. Villegas, F. Villasante, J. Armesto, L. O. Hedin, and H. Horn. 2014. Epiphytes improve host plant water use by microenvironment modification. Functional Ecology:1274-1283.

Stark, L. R., J. C. Brinda, and D. N. McLetchie. 2009. An Experimental demonstration of the cost of sex and a potential resource limitation on reproduction in the moss Pterygoneurum (Pottiaceae). American Journal of Botany 96:1712-1721.

Stark, L. R., B. D. Mishler, and D. N. McLetchie. 2000. The Cost of Realized Sexual Reproduction : Assessing patterns of reproductive allocation and sporophyte abortion in a desert moss 87:1599-1608.

Stoy, P. C., L. E. Street, A. V Johnson, A. Prieto-Blanco, and S. A. Ewing. 2012. Temperature, heat flux, and reflectance of common subarctic mosses and lichens under field conditions: might changes to community composition impact climaterelevent surface fluxes? Arctic Antarctic and Alpine Research 44:500-508.

Stuntz, S., U. Simon, and G. Zotz. 2002. Rainforest air-conditioning: The moderating influence of epiphytes on the microclimate in tropical tree crowns. International Journal of Biometeorology 46:53-59.

Tejo, C. F., D. Zabowski, and N. M. Nadkarni. 2015. Total and epiphytic litter under the canopy of Acer macrophyllum in an old-growth temperate rainforest, Washington State, USA. Canadian Journal of Forest Research 45:1654-1661.

Tilman, D. 1982. Resource Competition and Community Structure. Princeton University Press, Princeton, NJ.

Turetsky, M. R. 2003. The Role of Bryophytes in Carbon and Nitrogen Cycling. The Bryologist 106:395-409.

Turetsky, M. R., M. C. Mack, T. N. Hollingsworth, and J. W. Harden. 2010. The role of mosses in ecosystem succession and function in Alaska's boreal forest. Canadian Journal of Forest Research 40:1237-1264.

Turnbull, M. S., and Z. Lindo. 2015. Combined effects of abiotic factors on Collembola communities reveal precipitation may act as a disturbance. Soil Biology and Biochemistry 82:36-43.

Turner, J., N. E. Barrand, T. J. Bracegirdle, P. Convey, D. a. Hodgson, M. Jarvis, A. Jenkins, G. Marshall, M. P. Meredith, H. Roscoe, J. Shanklin, J. French, H. Goosse, M. Guglielmin, J. Gutt, S. Jacobs, M. C. Kennicutt, V. Masson-Delmotte, P. Mayewski, F. Navarro, S. Robinson, T. Scambos, M. Sparrow, C. Summerhayes, K. Speer, and A. Klepikov. 2014. Antarctic climate change and the environment: an update. Polar Record 50:1-23.

Ugolini, F. C., and J. G. Bockheim. 2008. Antarctic soils and soil formation in a changing environment: a review. Geoderma 144:1-8.

United Nations Department of Economic \& Social Affairs Population Division. 2014. World Urbanization Prospects, The 2014 Revision: Highlights. Page World Urbanization Prospects, The 2014 Revision: Highlights.

US Census Bureau Population Division. 2016. Annual Estimates of Resident Population: April 1, 2010 to July 1, 2015.

USDA-Forest Service. 2004. Lichen communities. Forest Inventory and Analysis 
Inventory and Analysis National Core Field Guide.

USDA-Forest Service. 2016. National Forest Air Quality and Lichen database and clearinghouse. http://gis.nacse.org/lichenair/index.php.

Velasco-Castrillón, A., J. A. E. Gibson, and M. I. Stevens. 2014. A review of current Antarctic limno-terrestrial microfauna. Polar Biology 37:1517-1531.

Vitousek, P. M., H. A. Mooney, J. Lubchenco, and J. M. Melillo. 1997. Human Domination of Earth's Ecosystems. Science 277:494-499.

Wall, D. H. 2007. Global change tipping points: Above- and below-ground biotic interactions in a low diversity ecosystem. Philosophical Transactions of the Royal Society B: Biological Sciences 362:2291-2306.

Wardle, D. A., M. Jonsson, S. Bansal, R. D. Bardgett, M. J. Gundale, and D. B. Metcalfe. 2012. Linking vegetation change, carbon sequestration and biodiversity: Insights from island ecosystems in a long-term natural experiment. Journal of Ecology 100:16-30.

Western, D. 2001. Human-modified ecosystems and future evolution. Proceedings of the National Academy of Sciences of the United States of America 98:5458-5465.

Wolf, A. L. 2009. Bird use of epiphyte resources in an old-growth coniferous forest of the Pacific Northwest.

Zhou, X., and M. A. Hemstrom. 2009. Estimating Aboveground Tree Biomass on Forest Land in the Pacific Northwest : A Comparison of Approaches. Page USDA Forest Service General Technical Report PNW-RP-584.

Zotz, G., and M. Y. Bader. 2009. Epiphytic Plants in a Changing World-Global: Change Effects on Vascular and Non-Vascular Epiphytes. Pages 147-170Progress in Botany. Springer Berlin Heidelberg. 


\section{Appendix A}

\section{List of Tables}

Table B.1 Carbon, nitrogen, hydrogen, and sulfur concentrations (\%) in blanks and Barley check standard (Leco 502-277) by Leco TruSpec combustion analysis....

\section{List of Figures}

Figure B.1 Repeatability of barley (Leco 502-277) check standard analysis for total C, H, $\mathrm{N}$, and $\mathrm{S}(\%)$ by Leco TruSpec combustion analyzer.

Figure B.2 Comparison of total C, N, and H (\%) analysis of replicate lichen samples by Leco TruSpec combustion analyzer.

Figure B.3 Comparison of total S (\%) analysis of replicate lichen samples by Leco TruSpec combustion analyzer.

Figure B.4 Comparison of total C, N, and H (\%) between urban Parmelia sulcata and Platismatia glauca

Figure B.5 Comparison of total S (\%) between urban Parmelia sulcata and Platismatia glauca.

Figure B.6 Regressions between Platismatia glauca and Parmelia sulcata N (\%) content collected across a regional urbanization site gradient. .135

Figure C.1 Bar graph showing ANOVA results by site location for nitrogenase activity in Lobaria pulmonaria collected across a gradient of increasing urbanization. 137

Figure C.2 Bar graph depicting ANOVA results by site location for cephalodia density, thalli thickness and sorediate index measures in Lobaria pulmonaria collected across a gradient of increasing urbanization.

Figure C.3 Bar graph showing the results of a theoretical biomass adjustment for $L$. pulmonaria and the resulting potential for nitrogen fixation (nitrogenase activity).....139

Figure D.1 Line graph showing intra-canopy $\mathrm{NO}_{\mathrm{x}}$ concentrations across a six-month sampling period in a $60 \mathrm{~m}$ tall urban $P$. menziesii tree.

Figure E.1 Supplemental summary statistics for 17 elements (Al, B, Ba, Ca, Co, Fe, K, $\mathrm{Mg}, \mathrm{Mn}, \mathrm{Mo}, \mathrm{Na}, \mathrm{P}, \mathrm{S}$ (\%, combustion analyzed), Si, Sr, Ti, V) for lichen tissues collected in seven different wilderness areas during the 2014 baseline Region 4 Wilderness surveys 


\section{Appendix B}

Supplemental Materials to Chapter 3: Implications of Increasing Urbanization on Canopy-Dwelling Epiphyte Communities in Tall Pseudotsuga menziesii in the Pacific Northwest, USA

Figure B.1 Repeatability of barley (Leco 502-277) check standard analysis for total C, H, $\mathrm{N}$, and S (\%) by Leco TruSpec combustion analyzer.

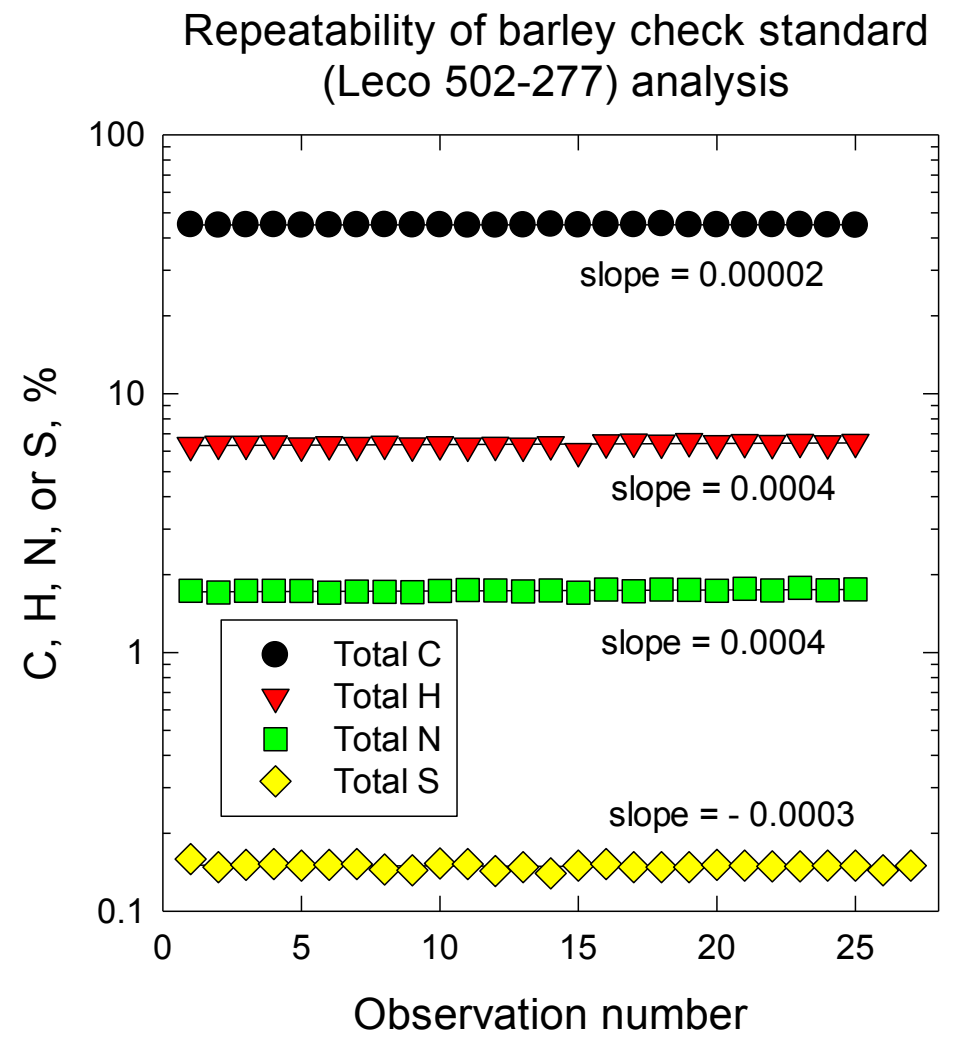


Table B.1 Carbon, nitrogen, hydrogen, and sulfur concentrations (\%) in blanks and Barley check standard (Leco 502-277) by Leco TruSpec combustion analysis.

\begin{tabular}{llrrrr}
\hline \multicolumn{1}{c}{ Standard } & \multicolumn{1}{c}{ Statistic } & \multicolumn{1}{c}{ Total C, \% } & Total N, \% & Total H, \% & Total S, \% \\
\hline Blanks & N & 8 & 7 & 8 & \\
& Mean & -0.03 & -0.001 & 0.02 & \\
& Standard deviation & 0.00 & 0.000 & 0.01 & \\
& Coefficient of & & & & \\
& variation, \% & -0.26 & -37.65 & 25.12 & \\
& Standard error & 0.00 & 0.000 & 0.00 & \\
& Minimum & -0.03 & -0.002 & 0.02 & \\
& Maximum & -0.03 & -0.001 & 0.03 & \\
Barley & N & & & & \\
standard & & 25 & 25 & 25 & \\
& Mean & 44.91 & 1.734 & 6.38 & 0.149 \\
& Standard deviation & 0.13 & 0.019 & 0.11 & 0.004 \\
& Coefficient of & & & & \\
& variation, \% & 0.29 & 1.07 & 1.75 & 2.49 \\
& Standard error & 0.03 & 0.004 & 0.02 & 0.001 \\
& Minimum & 44.74 & 1.704 & 5.99 & 0.140 \\
Certified & Maximum & 45.35 & 1.779 & 6.54 & 0.159 \\
range & & & & & \\
\hline & & $44.58-45.63$ & $1.66-1.81$ & $6.28-6.44$ & $0.137-0.159$ \\
\hline
\end{tabular}


Figure B.2 Comparison of total C, N, and H (\%) analysis of replicate lichen samples by Leco TruSpec combustion analyzer.
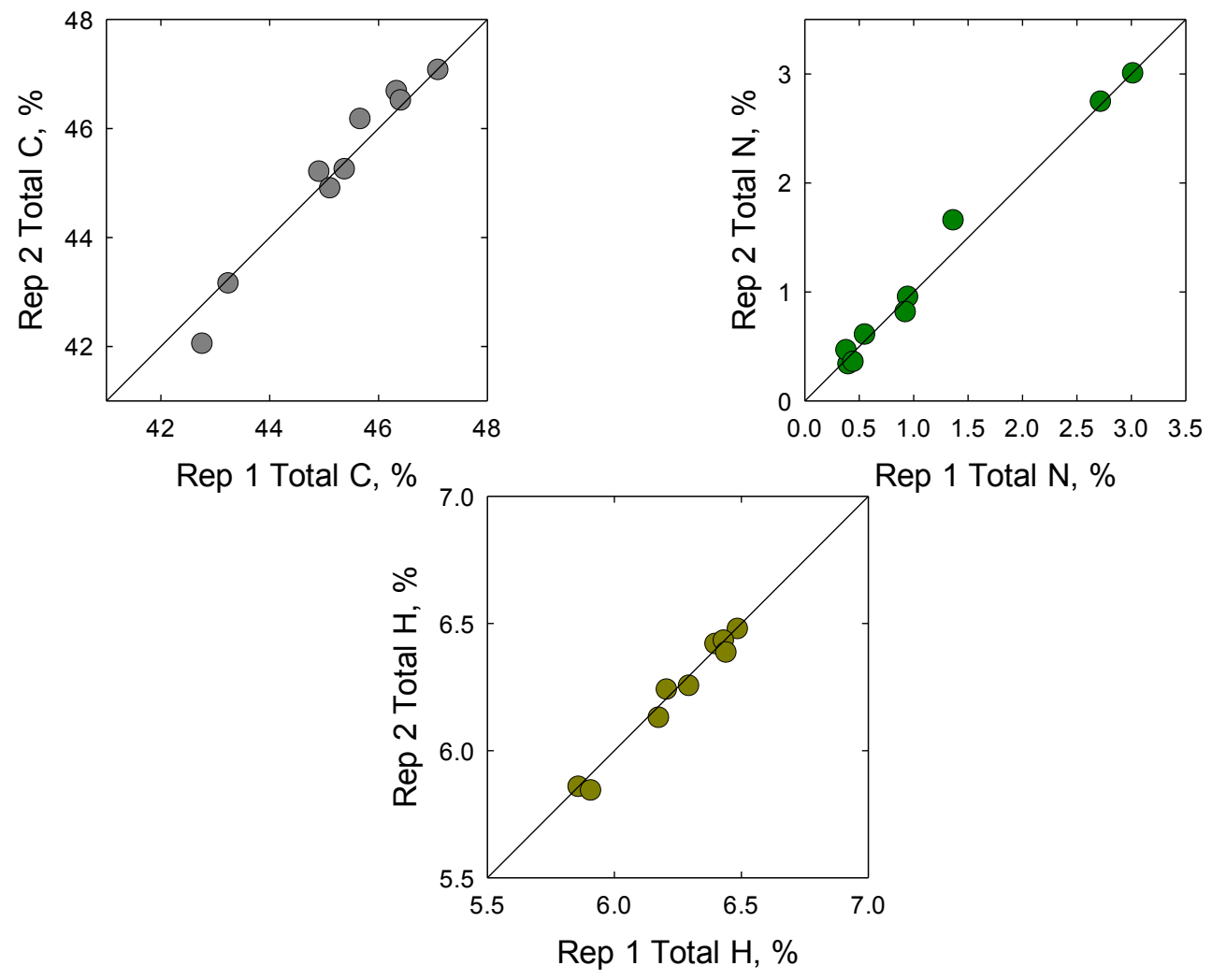
Figure B.3 Comparison of total S (\%) analysis of replicate lichen samples by Leco TruSpec combustion analyzer.

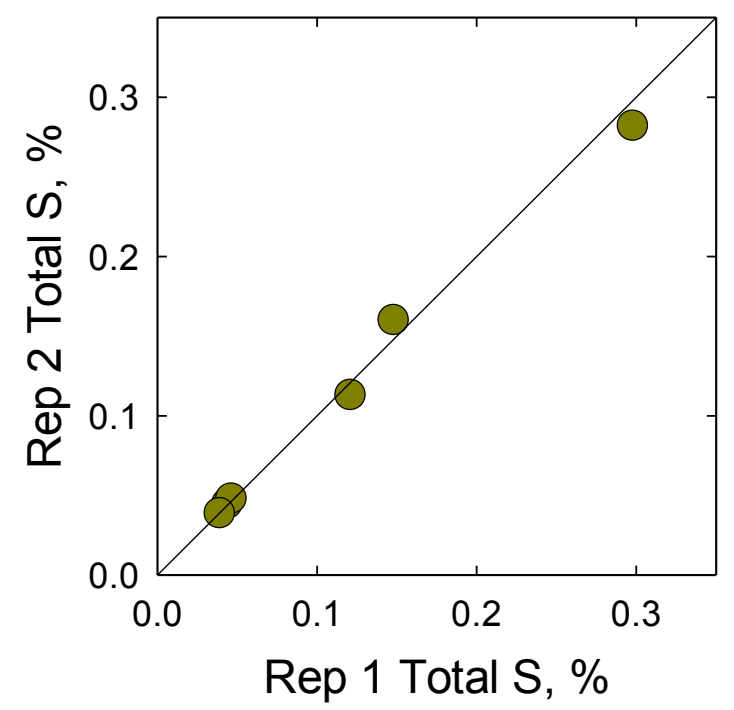


Figure B.4 Comparison of total C, N, and H (\%) between urban Parmelia sulcata and Platismatia glauca.

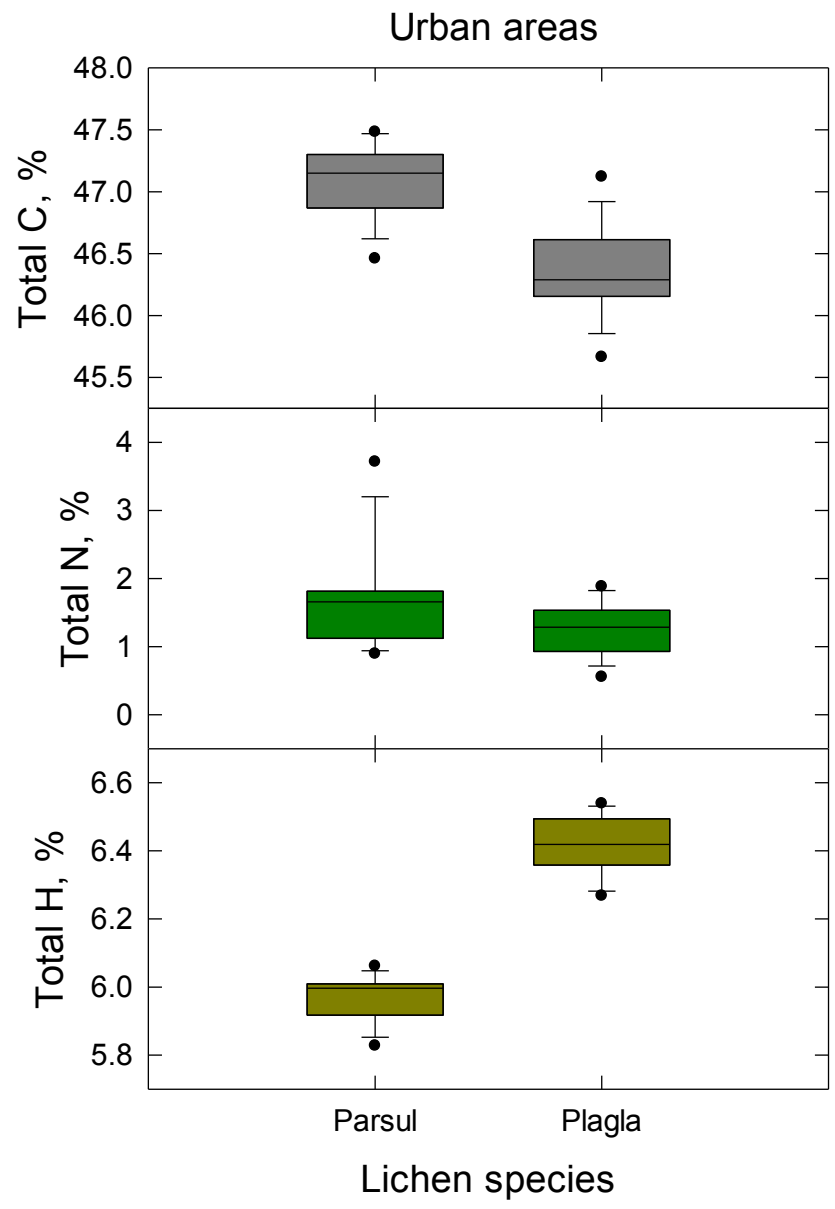


Figure B.5 Comparison of total S (\%) between urban Parmelia sulcata and Platismatia glauca.

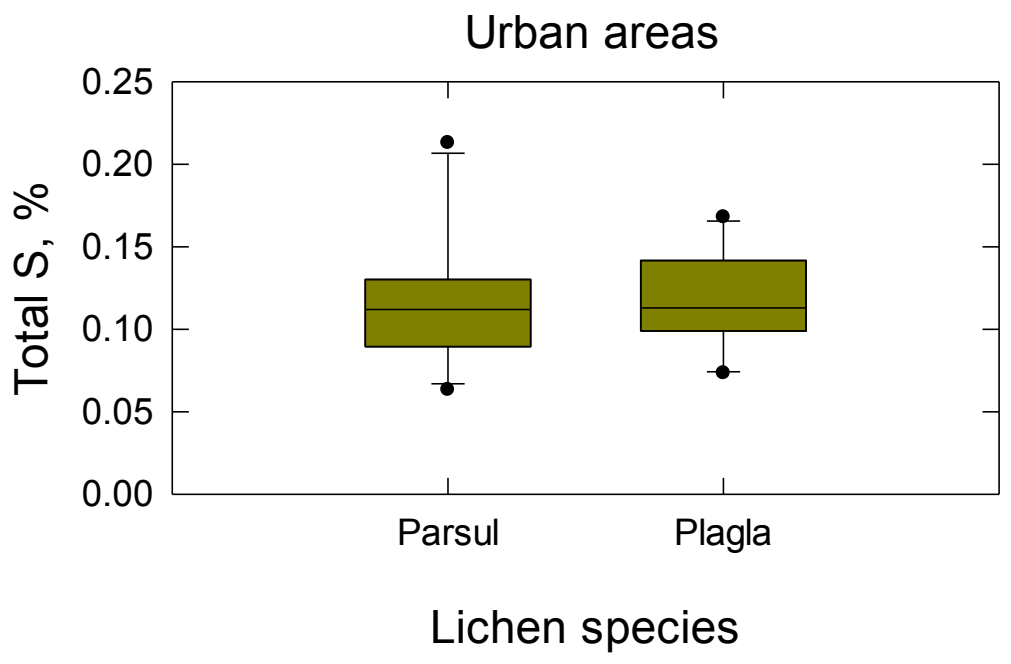


Figure B.6 Regressions between Platismatia glauca and Parmelia sulcata N (\%) content collected across a regional urbanization site gradient. The correlation indicates the strength of the relationship $\left(r^{2}=0.91\right)$.

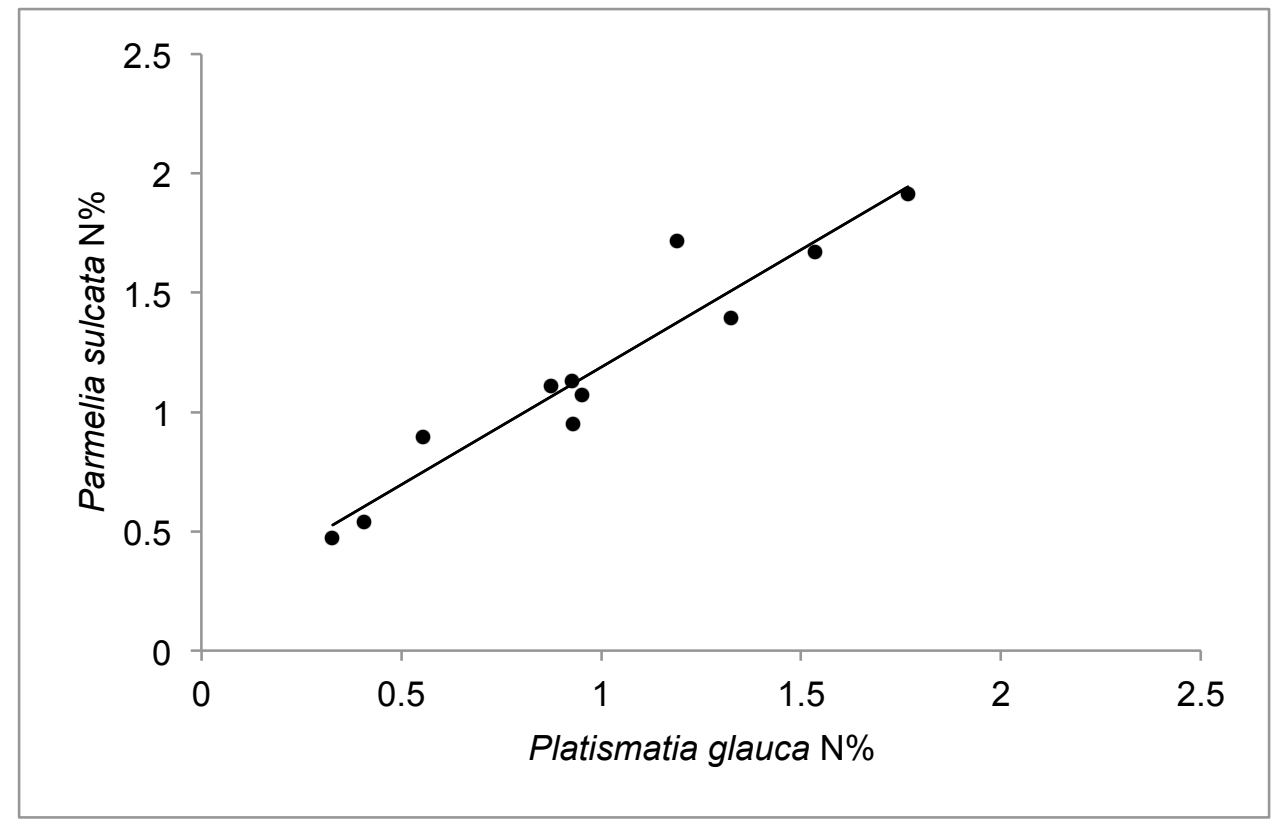




\title{
Appendix C
}

\section{Implications for Canopy Nitrogen Fixation in dominant cyanolichen Lobaria pulmonaria Across a Gradient of Urbanization in the Pacific Northwest, USA}

\begin{abstract}
Tree canopy sourced $\mathrm{N}$ fixation is an important source of new $\mathrm{N}$ in the coniferous forests of the Pacific Northwest Region, USA. Large, stratified habitats provide an ideal habitat for many lichens and mosses, both of which have been established for their contribution to canopy-sourced biological nitrogen fixation (BNF). We measured enzymatic activity of iconic Pacific Northwest canopy-dwelling N-fixing lichen, Lobaria pulmonaria, across a gradient of increasing urbanization outside of Portland, Oregon, USA. We found evidence that $\mathrm{N}$ fixation was not affected on the organismal level, and that similar rates of $\mathrm{N}$ fixation occurred in the urban environment to that of rates in remote sites. Similarly, the density of cephalodia per thalli was also unaffected by site location. However, the dramatic decline of this species in urban areas allowed us to calculated theoretical biomass adjustments to address this decline and we found that biological nitrogen fixation from canopy-dwelling Lobaria pulmonaria will be dramatically affected by increasing urbanization.
\end{abstract}


Figure C.1 Mean ( ${ } \mathrm{SE}$ ) nitrogenase activity $\left(\mathrm{nmol} \mathrm{C}_{2} \mathrm{H}_{4} \mathrm{~g}^{-1} \mathrm{~h}^{-1}\right)$ measured per thalli in Lobaria pulmonaria collected across an urbanization site gradient $(n=3$ sites per each land use type). No significant effects were observed for spring season $\mathrm{N}$ fixation rates with increasing urbanization; one-way ANOVA, $\mathrm{F}=2.77, \mathrm{p}=0.07, n=15$.

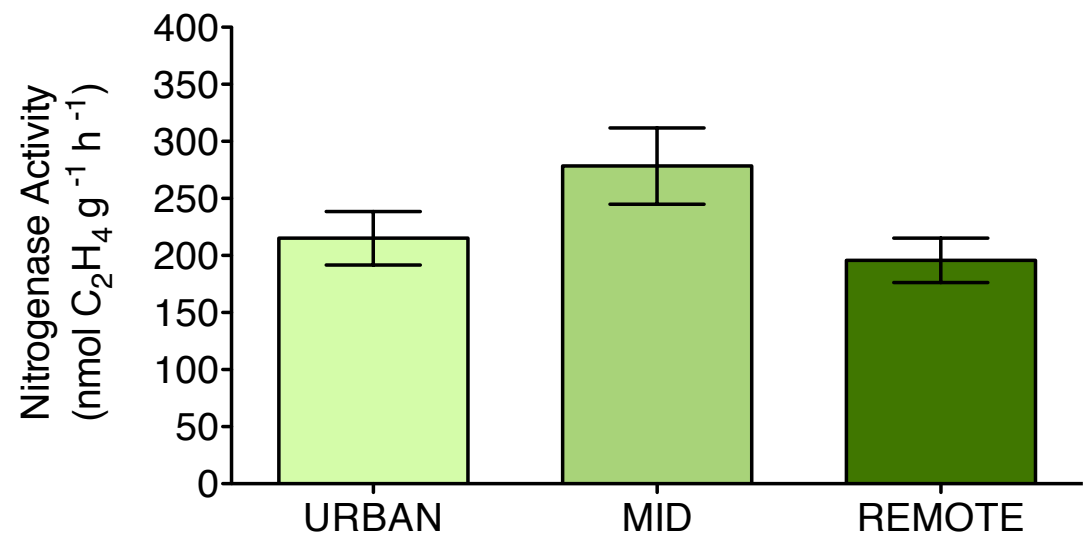


Figure C.2 Three additional thalli characteristics were measured in L. pulmonaria collected across an urbanization site gradient ( $n=3$ sites per each land use type). a) Mean $( \pm \mathrm{SE})$ cephalodia density (count per/ $\mathrm{cm}^{2}$ ) in thalli was not affected by urbanization, oneway ANOVA, $\mathrm{F}=0.10, \mathrm{p}=0.91, n=15$; b) Mean $( \pm \mathrm{SE})$ thalli thickness $(\mathrm{mm})$ was significantly thicker in mid and urban sites, one-way ANOVA, $\mathrm{F}=18.84, \mathrm{p}=0.001, n=15$; c) Mean $( \pm \mathrm{SE})$ sorediate index was classed on a 1-5 scale indicating percent of thalli covered in sorediate eruptions; remote sites showed significantly less soredia on thalli than urban thalli, one-way ANOVA, $\mathrm{F}=5.32, \mathrm{p}=0.01, n=15$.

a

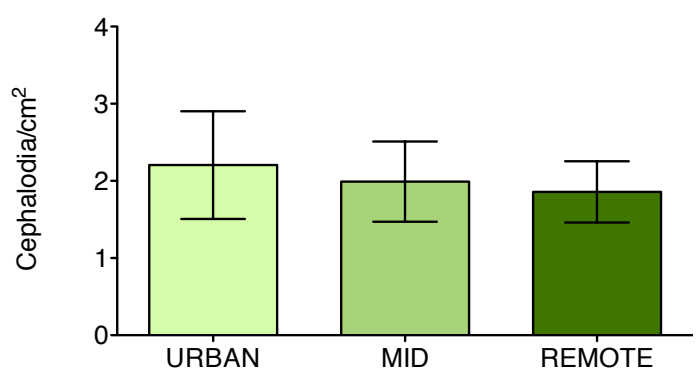

b

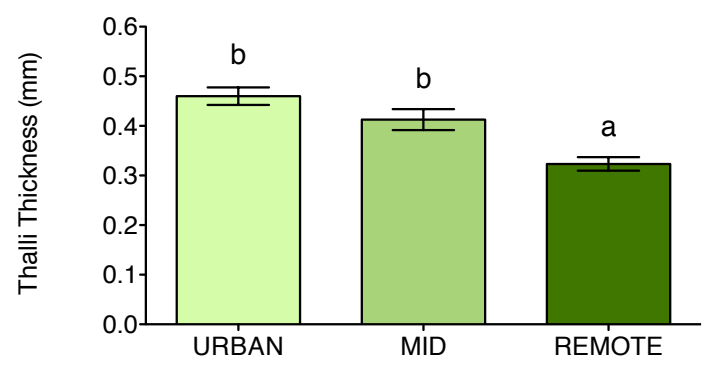

C

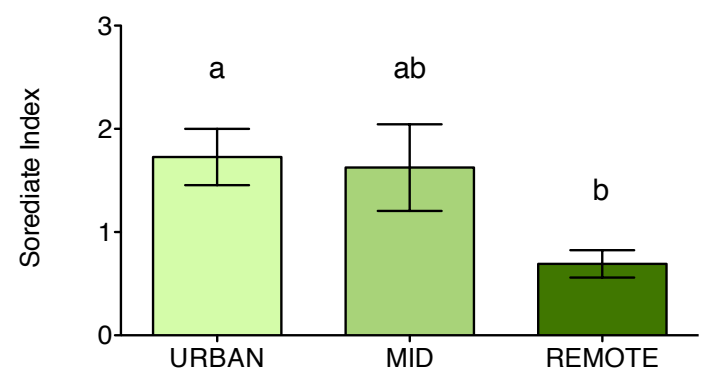


Figure C.3 a) Theoretical biomass adjustment for L. pulmonaria across a gradient of increasing urbanization. Values were adjusted based on biomass estimates from McCune (1994) and reveals that as L. pulmonaria biomass decreases per tree, nitrogen fixation also decreases. b) Theoretical potential for nitrogen fixation was calculated using max potential for remote sites and calculated for a $75 \%$ and $95 \%$ reduction in biomass of $L$. pulmonaria with increasing urbanization, resulting on significant decrease in canopy derived nitrogen fixation.

a

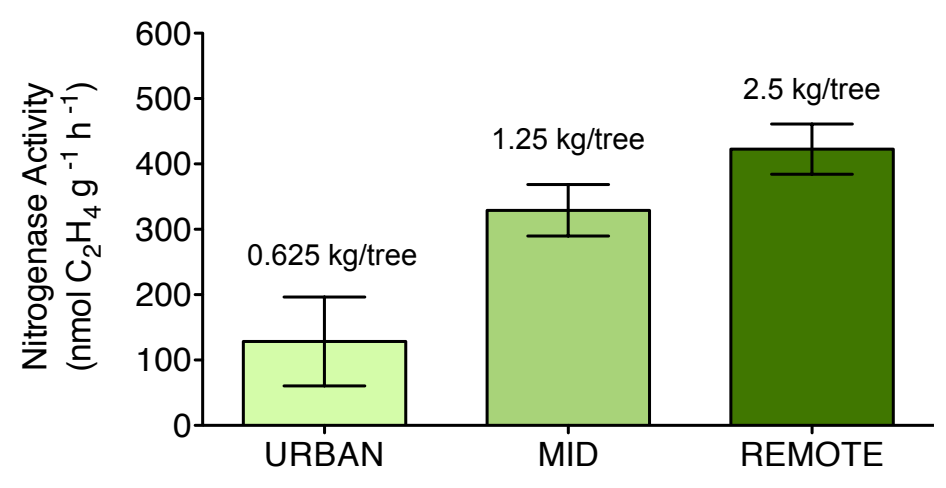

b

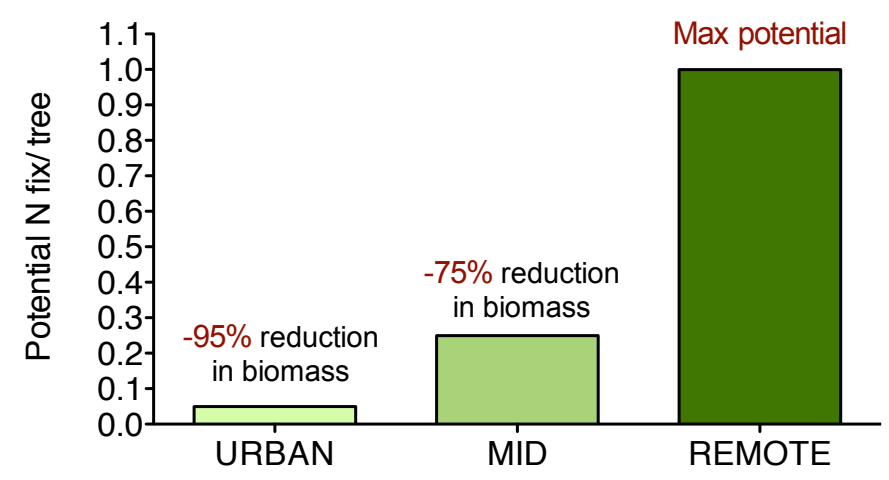




\section{Appendix D}

\section{Measurements of intra-canopy NOx concentrations in tall Pseudotsuga menziesii}

\section{Study Description}

To further understand the movement of urban transportation-based pollutant air masses in tree canopies, we measured in-situ concentrations of nitrogen dioxide $\left(\mathrm{NO}_{\mathrm{x}}\right)$ with $\mathrm{Ogawa}$ passive samplers (Ogawa and Company, Pompano Beach, Florida, USA). $\mathrm{NO}_{\mathrm{x}}$ concentrations were sampled once monthly, over a six-month period (June- November 2014). Ogawa $\mathrm{NO}_{\mathrm{x}}$ samplers were deployed for two-week intervals to obtain a monthly measurement point during the sampling period. Samplers were placed in a $60 \mathrm{~m}$ tall $P$. menziesii located in the SE section of Forest Park, Portland, Oregon. Twenty samplers were used during the study. 17 samplers were placed at three canopy heights $59 \mathrm{~m}, 46 \mathrm{~m}$, and $35 \mathrm{~m}$. Samplers were placed in protective housings (PVC pipe end caps attached with zipties) in each cardinal direction (NSEW) and one sampler at the bole, providing 5 points of measure at three canopy locations. Two additional samples with housings were placed at $28 \mathrm{~m}$ and $22 \mathrm{~m}$ on the bole below the live crown and were attached to the tree bole with cording. Three samplers were located at ground level at $2.5 \mathrm{~m}$ on small trees located within the dripline of the study tree.

Reference samplers were placed at Portland State University, in Downtown Portland, Oregon, USA and at an Oregon Department of Environmental Quality (DEQ) air quality monitoring station at SE Lafayette, Portland, Oregon, USA during each sampling event over the six-month sampling period. Canopy temperature and humidity was measured using dataloggers (Hobo Pro v2, Onset Computer Corporation, Bourne, 
Massachusetts) co-located with passive samplers. Samplers were analyzed at Portland State Laboratories using standard colorimetric methods (Ogawa \& Co. Inc. 2006). 
Figure D.1 Mean $( \pm \mathrm{SE})$ nitrogen oxide concentrations $\left(\mathrm{NO}_{\mathrm{x}}\right)(\mathrm{ppb})$ (nitric oxide [NO] and nitrogen dioxide $\left[\mathrm{NO}_{2}\right]$ ) measured at ground-level and within stratified canopy layers of an urban P. menziesii tree canopy located in Forest Park, Portland, OR, USA over sixmonth monitoring period (June- November 2014). Intra-canopy measures were reflective of ground-level concentrations and results show no significant stratification of urban pollutant air masses occurred within canopy measures; one-way ANOVA, $\mathrm{F}=3.17$, $\mathrm{p}=0.08, n=20$.

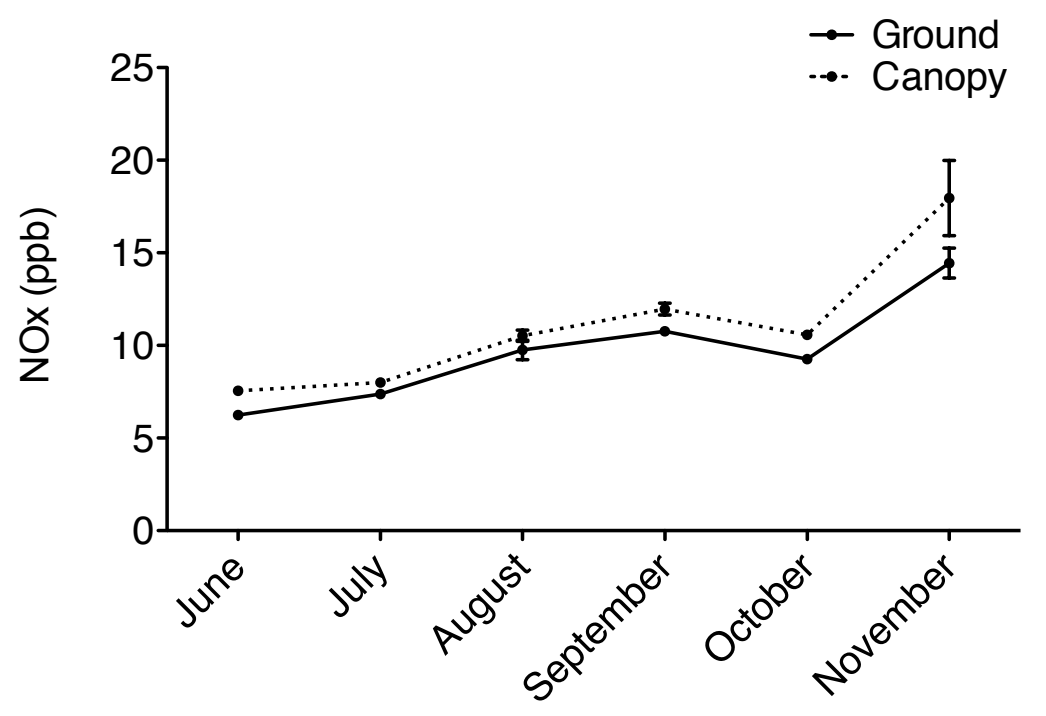




\section{Appendix E}

\section{Cascades to Coast GK12 Curriculum: \\ Exploring Spatial Patterns of Lichens and Air Quality in the Pacific Northwest}

PSU Fellow: Hannah Prather, Department of Biology

Partner Teacher: Kathy Childress, Gresham High School

\section{Learning Goal:}

- Collect and analyze spatial data and lichen species distributions in relation to local air quality.

\section{Learning Objectives:}

- Introduce concepts of air pollutants originating from urban cities, have students identify sources, and discuss environmental impacts of urban pollutants

- Introduce students to the concept of bioindicators, specifically lichens as indicators of air quality

- Students will develop note taking skills from a scientific presentation

- Students will conduct an online scientific investigation exploring lichen distributions and air quality with online databases

- Students will learn to retrieve data from online database to answer scientific questions and create spatial maps of lichen distributions and pollutant sources

- Students will develop skills graphing and analyzing data, draw conclusions, and present their findings in classroom presentations

Target Grade: 9th-12th Grades 


\section{Oregon State Standards:}

H-2E4 Evaluate the impact of human activities on environmental quality and the sustainability of Earth systems.

H-3S-3 Analyze data and identify uncertainties. Draw a valid conclusion, explain how it is supported by the evidence, and communicate findings of a scientific investigation HS-ESS3-1 Construct an explanation based on evidence for how the availability of natural resources, occurrence of natural hazards, and changes in climate have influenced human activity.

HS-ESS3-4 Evaluate or refine a technological solution that reduces impacts of human activities on natural systems.

HS-ESS3-6 Use a computational representation to illustrate the relationships among Earth systems and how those relationships are being modified due to human activity.

\section{Activity Summary:}

Students will learn about urban air pollution and how living organisms can act as bioindicators (living-indicators) from an interactive power point lecture which is presented as a scientific lecture from a guest scientist (PSU graduate student). Students also learn about large databases online to acquire information about lichens and regional air quality.

The background information allows students to make predictions of where regional pollution sources are in the Portland Area and where they predict the presence/absence of certain indicating lichen species (simplified to a single urban-tolerant species and a single urban sensitive species). Students' use printed Google maps to spatially map their predictions and then collect lichen species distribution data from the 
online database, in a guided activity, to either validate or refute their predictions. Students gain skills accessing data from large online databases and develop skill using Microsoft Excel to analyze and graph their data. Student results are presented as class presentations to conclude the activity.

\section{Timeline:}

First Class period (50 minutes):

Give students presentation on the types of air pollutants which arise from urban cities, describe emission sources and environmental and health impacts to sensitive organisms (including humans!). The background presentation is given as a scientific presentation in PowerPoint (lecture available via GK12 website) and student practice note-taking skills and contribute to discussion as encouraged. Students are encouraged to contribute in an interactive method, coming up with pollutant sources (freeways, industrial areas, railroads, etc.) and how pollutants can harm human and ecosystem health (asthma, cancer, acid rain, eutrophication, etc.).

\section{Second Class period (50 minutes):}

Give students a short PowerPoint presentation on lichen biology, lichen morphology, and their use as bioindicators, again students are encouraged to participate as encouraged and practice taking notes (lecture available via GK12 website). Students should be encouraged to draw pictures of the lichen morphology in their notes to help them remember the different morphological characteristics. Five different dried lichen samples are then passed out to table groups and student use their notes to identify the different 
morphology types they see. Have student groups work together to use their notes to identify the morphologic types of the lichen samples.

Third Class period (50 minutes):

Refresh students on the lecture points from the background air pollutant and lichen biology lessons. Introduce students to all-star lichen indicators: "dirty air" species Xanthoria parientina and "clean air" species Lobaria oregana, using pictures and/or actual dried samples. Give students printed Google maps of the Portland/Gresham area and have students use colored pencils to identify where they think large pollutant sources are (industrial areas, freeways and highways, railroads, etc.). Then have students draw locations of where they predict to find our two lichen indicators on the same map. Introduce students to an online database from the USFS National Lichens and Air Quality Program (http://gis.nacse.org/lichenair/), which monitors lichens all around the Pacific Northwest Region.

Fourth Class period (50 minutes):

Give students a worksheet that guides them through mapping our two lichen indicator species (X.parientina and L.oregana) and have students collect 'air score' data from the database and record on worksheet. Have students work in pairs on their worksheets and create maps of lichen indicator distributions ad begin to input the 'air scores' into Microsoft Excel to create a graph of their findings.

Fifth Class period (50 minutes): 
Have students continue to work on completing database activity and using excel to graph the average air score for the sites they select. Have students begin to work on their class presentations, where they state their spatial predictions, show their 'air score' analysis, and provide a conclusion on if their inquiry supported or refuted their predictions.

Additionally, encourage students to offer solutions and problem solve how we could limit negative pollution inputs on sensitive biota.

\section{Sixth Class period (50 minutes):}

Have the student pairs present their findings in class presentations, they should discuss their spatial predictions (where they thought pollution sources were and the indicator lichens they researched in the database), an analysis of their 'air score' data and an explanation of what their data means, and a conclusion from their analysis. Encourage students to offer one idea or technological solution that could reduce impacts of pollutants on natural systems.

\section{Activity Plan:}

First Class Period: Introduction to Urban Air Pollution

Activity begins with a guest scientist (PSU Biology Graduate Student) lecture on the types of urban air pollutants that come from urban cities, using a PowerPoint style lecture (available from GK12 website). Students are engaged in questions throughout the lecture, to help make lists on the chalkboard of pollution sources that they can think of in their area. The lecture contains primarily photos and pictures and begins discussing what air is made up of, how human activities can change the composition of air with pollutants, 
sources of pollutants, and why we should care (human health, environmental impacts like acid rain, eutrophication, and impacts to sensitive organisms). Students practice taking notes during the presentation in their designated science notebooks. The teacher and guest scientist help guide the note taking by prompting students and allowing time for students to make notes during. Each section of the lecture should have 1-3 student bullet points to record (sources of pollutants, impacts from pollution on human health and ecosystem health, etc.).

Second Class Period: Introduction to Lichen Biology and Lichens as "Living-Indicators" This activity begins with a short, guest scientist led PowerPoint lecture on lichen biology, lichen morphology, and the use of lichens as bioindicators (lecture available from GK12 website). The PowerPoint is made up of mostly large photos and pictures and little text. Students continue to practice note taking with prompting from teacher and guest scientist. Students learn about what lichens are, basic biology of the lichen symbiosis, what type of morphology they exhibit (foliose, fruticose, and crustose), and their use as sensitive bioindicators of ecosystem stress and air pollution. Some topics to include in student are bullet points about what partners make a lichen symbiosis, the three morphologic forms of lichens, and why lichens are so sensitive to air pollutants. At the end of the lecture students are given a quick visual test on the lichen morphology, large pictures are shown on the screen of different lichens and student raise their hands and answer what morphology they think it shows and their supporting rationale (characteristics from their notes that describe the growth form they choose). After the lecture, sets of five different dried lichen samples, which are preserved in sealed petri plates, are handed out to each 
student table group. Each lichen is labeled with a number and the students should work together as a group to identify the morphology of each lichen with their supporting rationale as to why they selected that form. Towards the end of the class period, each student group will present to the class which morphology they assigned to the numbered lichen samples and the entire class chooses to agree or dispute their conclusion. If the teacher chooses, an assessment of student learning can be added, for example: one question I have about lichens, or one thing I would like to know more about, etc. The guest scientist can choose a few of these questions to answer in another class session.

Third and Fourth Class Periods: Student predictions, data collection from an online database and spatial mapping activity

Students are refreshed on what they have learned about air pollution and the use of lichens as bioindicators of air quality. Students are then introduced to two all-star lichen indicators: "dirty air" species Xanthoria parientina and "clean air" species Lobaria oregana, using pictures and/or actual dried specimens. Students learn that when these species are present in an area, it can tell us a great deal about the cleanliness of the air. Students are then divided into pairs and given printed Google maps of the Portland/Gresham area. Student pairs work together to make predictions about lichen indicators and pollution sources in their area. The students can use colored pencils to identify areas on the map where they think large pollutant sources are located (industrial areas, freeways and highways, railroads, etc.). Students then draw in locations on the map where they predict to find the two lichen indicators (X.parientina and L.oregana). After students have made their predictions, they are introduced to an online database from the 
USFS National Lichens and Air Quality Program, which has a large network monitoring lichens and air quality all around the Pacific Northwest Region. The student pairs are given handouts that guide them through a spatial map query of the distributions of the two lichen indicator species near the Portland/Gresham area. By using the handout, students get practice following a detailed set of instructions, retrieving spatial data for two indicator lichen species, collecting 'air score' data points for four locations with X.parientina and four locations with L.oregana. The air scores are derived from a USFS model which provides a quantitative "air quality" value for any site, the higher the numeric value, the cleaner the air is. Students continue to work as pairs on mapping the indicator lichen distributions and collecting the 'air score' values for the remainder of the class periods.

\section{Fifth Class Period: Analysis and Presentations}

The students continue to work on completing database activity and begin to use Microsoft Excel to input their 'air score' values and calculate the mean 'air score' for the six locations they selected. Once the students have the mean 'air score' they can make bar graphs to display their data in Excel. If the teacher chooses, students can also calculate the variance of the datapoints and show it graphically. Students should begin to work on their final class presentations. The presentations are to be given PowerPoint format and should include the following information:

- Background on air quality and lichens

- A clear statement of their spatial predictions - where they predict pollution sources and the predicted distributions of the two indicator lichen species 
- One graph of the mean 'air score' for sites with the two indicator lichen species present

- A conclusion slide to describe if their database inquiry supported or rejected their predictions

- One solution for how we can limit pollution inputs on sensitive organisms.

Towards the end of the period, a short discussion is led with the class to talk about their final conclusions from the data they generated and other observations on their findings (distance to pollution sources, distance to roadways/freeways, amount of forest land, etc.).

Sixth Class Period: Student Presentations

Student groups will present a PowerPoint style presentation to the class, each student needs to present a portion of the presentation. An additional class period can be added if needed for all student presentations.

Related Concepts: climate, GIS spatial mapping, weather, stream bioindicators Materials/Worksheets:

- Introductory Air Quality and Lichen PowerPoint presentations

- Lichen database worksheet and Google maps

- Dried Lichen Samples

- Access to student computers or laptops 


\section{Extensions:}

This activity can be easily incorporated alongside other GK12 science inquiry curricula, it can be taught either before or after the NOx inquiry because students are already introduced to the concepts of urban air pollutants. This curriculum also pairs nicely with activities related to stream monitoring with invertebrates (another type of bioindicator).

\section{Assessment:}

Student presentations can be used as a form of assessment. Students can verbally explain their understanding of lichens as bioindicators of air quality, some potential pollutant sources in their areas, and their quantitative and spatial analysis of what they found via the USFS air quality and lichen database. Students should also describe their thoughts on how humans are impacting natural environments and provide any potential solutions.

Handouts and lecture materials available from the Portland State University, Cascade to Coast GK12 Curriculum website: https://www.pdx.edu/soe-gk12/curriculum 


\section{Appendix F}

\section{Baseline Lichen Biomonitoring in USFS Region 4 Wilderness Areas}

\section{Project Summary:}

In 2014, I collaborated with the USFS Region 4 Wilderness/ Wild \& Scenic Rivers Program and Region 6 ARM (Air Resource Management) and FIA (Forest Inventory Analysis) programs to establish baseline Wilderness lichen biomonitoring plot in seven wilderness areas (Ashdown Gorge, Box-Death Hollow, Cottonwood Forest, Dark Canyon, Lone Peak, Mount Naomi, Wellsville) located in three in national forests (Dixie NF, Uinta-Wasatch-Cache NF, and Manti-LaSal NF) all located in the state of Utah. The goal of this project was to meet the 10-Year Wilderness Stewardship Challenge (10YWSC) by assessing, evaluating and monitoring air quality in Wilderness. Lichen communities and elemental tissue accumulation following Forest Inventory Analysis (FIA) lichen community protocols were measured for the first time, at 16 plots established in the seven subject wilderness areas. Seven Wilderness Lichen Biomonitoring Reports and an Appendix to the reports are provided below as a summary of the work performed during the baseline monitoring 2014 field season. 


\section{Ashdown Gorge Wilderness}

\section{Wilderness Plot Establishment}

The purpose of air quality biomonitoring in Wilderness is to assess the status and trends of air pollutants that can affect air quality related values such as the diversity, composition, and health of flora and fauna. The target density for air quality biomonitoring plots in Intermountain Region Wilderness Areas is 1 plot per 20,000 acres. Individual plots are to be re-sampled every 10 years. The following table summarizes the biomonitoring plots established in the baseline year. To learn more about the rationale for lichen monitoring, read the Region 4 Introductory Wilderness Air Quality 2014 Lichen Biomonitoring report. To map plot locations and obtain plot specific data go to http://gis.nacse.org/lichenair/index.php?page=query\&type=plot.

\begin{tabular}{|lcc|}
\hline & & Year Established \\
\hline \hline Plots established & 2 & 2014 \\
Wilderness Acreage & 7,043 & \\
Plots left to meet baseline goal & 0 & \\
\hline
\end{tabular}

\section{Lichen Tissue Elemental Concentrations}

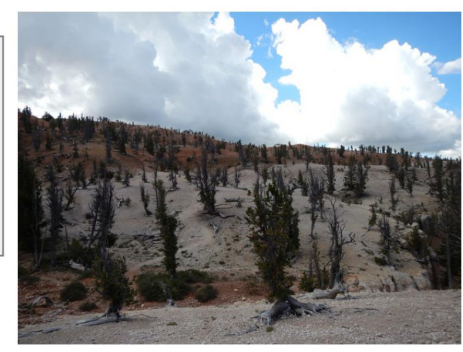

The goal of baseline lichen elemental tissue monitoring is to assess current pollutant concentrations and track how they may change, or not change, over time. Pollutant concentrations in epiphytic lichens are correlated with the amounts of pollutants deposited from the atmosphere to vegetation and soils. This table provides baseline elemental values of lichen tissue concentrations for common, abundant epiphytic lichen species found in the Wilderness, shown below as concentration (ppm or \% per dry weight of lichen tissue) of nitrogen, sulfur, arsenic, cadmium, chromium, copper, nickel, lead, and zinc, summarized by species. All values were related to mean regional threshold values determined for lichen tissues in the PNW Region; those exceeding threshold values for clean sites are highlighted in bold typeface. Further discussion of lichen $\mathrm{N}$ and $\mathrm{S}$ concentrations (\%) are provided in the appendix. Determination of these values to define clean site threshold values specific to the Intermountain Region requires development of a regional lichen-based gradient model.

\begin{tabular}{|c|c|c|c|c|c|c|c|c|c|}
\hline & $\begin{array}{l}\mathrm{N} \\
\%\end{array}$ & $\begin{array}{l}\mathbf{S} \\
\%\end{array}$ & $\begin{array}{l}\text { As } \\
\text { ppm }\end{array}$ & $\begin{array}{c}\mathrm{Cd} \\
\mathrm{ppm}\end{array}$ & $\begin{array}{c}\mathrm{Cr} \\
\mathrm{ppm}\end{array}$ & $\begin{array}{c}\mathrm{Cu} \\
\mathrm{ppm}\end{array}$ & $\begin{array}{c}\mathrm{Ni} \\
\mathrm{ppm}\end{array}$ & $\begin{array}{c}\mathrm{Pb} \\
\mathrm{ppm}\end{array}$ & $\begin{array}{l}\mathrm{Zn} \\
\mathrm{ppm}\end{array}$ \\
\hline \multicolumn{10}{|c|}{ Melanelia subolivacea } \\
\hline \multicolumn{10}{|l|}{$n=1$} \\
\hline mean & 1.7 & 0.0 & 0.4 & 0.1 & 0.8 & 4.7 & 0.6 & 1.9 & 14.9 \\
\hline \multicolumn{10}{|c|}{ Xanthoparmelia plittii } \\
\hline \multicolumn{10}{|l|}{$n=2$} \\
\hline mean & 1.1 & 0.1 & 0.4 & 0.2 & 1.4 & 4.5 & 0.9 & 7.4 & 14.6 \\
\hline $\min$ & 1.0 & 0.1 & 0.4 & 0.2 & 1.3 & 3.9 & 0.7 & 4.8 & 11.2 \\
\hline $\max$ & 1.3 & 0.1 & 0.5 & 0.2 & 1.6 & 5.2 & 1.1 & 10.0 & 18.0 \\
\hline
\end{tabular}




\section{Ashdown Gorge Wilderness}

\section{Community Composition \& Species Sensitivities}

Composition of the epiphytic macrolichen community (non-crustose species on woody substrates) within a plot determines that plot's position along larger regional pollution and climate gradients. The table below summarizes lichen species observed in all plots established in the baseline year, including crustose and ground dwelling species voluntarily collected by surveyors, as well as epiphytic species used in air quality tissue analyses. In lieu of a regional lichen-based gradient model, lichen sensitivity ratings were categorized according to the sensitivity ratings for $\mathrm{N}$ and $\mathrm{S}$ pollutants derived from species distributions in the western United States (Geiser \& Root, in prep). Pollution sensitivity ratings: $\mathbf{M S}=$ most sensitive, $\mathbf{S}=$ sensitive, $\mathbf{I}=$ intermediate, $\mathbf{T}=$ tolerant, $\mathbf{U}=$ unknown. For plot specific species lists for this Wilderness area go to:

http://gis.nacse.org/lichenair/index.php?page=query\&type=community.

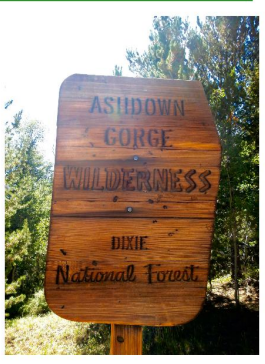

\begin{tabular}{lcc} 
Species Name & N-Sensitivity & S-Sensitivity \\
\hline Melanelia subolivacea & $\mathrm{U}$ & $\mathrm{S}$ \\
Melanohalea elegantula & $\mathrm{S}$ & $\mathrm{S}$ \\
Physcia adscendens & $\mathrm{T}$ & $\mathrm{T}$ \\
Physcia aipolia & $\mathrm{T}$ & $\mathrm{I}$ \\
Physcia stellaris & $\mathrm{I}$ & $\mathrm{T}$ \\
Physciella melanchra & $\mathrm{T}$ & $\mathrm{S}$ \\
Polycauliona polycarpa & $\mathrm{T}$ & $\mathrm{T}$ \\
Ramalina sinensis & $\mathrm{I}$ & $\mathrm{S}$ \\
Usnea lapponica & $\mathrm{S}$ & $\mathrm{S}$ \\
Xanthomendoza fulva & $\mathrm{U}$ & $\mathrm{U}$ \\
Xanthomendoza montana & $\mathrm{U}$ & $\mathrm{U}$ \\
Xanthoparmelia plittii & $\mathrm{U}$ & $\mathrm{U}$ \\
\hline Total species richness & &
\end{tabular}

Elevated nitrogen and sulfur deposition has distinct effects on epiphytic lichen community composition. Clean air plots with low nitrogen and/or sulfur deposition have a higher frequency of sensitive species than tolerant species. The proportions of species indicative of nitrogen and sulfur deposition for this Wilderness are listed in the table below. The frequency of $\mathrm{N}$-tolerant species (33\%) suggests early signs of elevated $\mathrm{N}$ deposition are occurring in this Wilderness. However, at the regional scale, tissue concentrations of $\mathrm{N}(\%)$ collected in this Wilderness were among the lowest values observed across the seven Wilderness areas surveyed in the baseline year. Additionally, the high frequency of S-sensitive species (42\%) detected suggests that sulfur deposition is minimal in this Wilderness area.

\begin{tabular}{lcc} 
& $\begin{array}{c}\text { Frequency (\%) } \\
\text { N-Sensitive }\end{array}$ & $\begin{array}{c}\text { Frequency (\%) } \\
\text { S-Sensitive }\end{array}$ \\
\hline Most Sensitive & 0 & 0 \\
Sensitive & 17 & $\mathbf{4 2}$ \\
Intermediate & 17 & 8 \\
Tolerant & $\mathbf{3 3}$ & 25 \\
Unknown & 33 & 25 \\
\hline
\end{tabular}




\section{Ashdown Gorge Wilderness}

\section{Baseline Monitoring Summary}

The baseline information provided here suggests an intact lichen flora, typical of other lichen floras of the Intermountain Region and the greater central valley of California. The frequency of N-tolerant species (33\%) detected suggests that sensitive lichen communities may be indicating early signs of elevated $\mathrm{N}$ deposition in this Wilderness. Yet, sulfur deposition appears minimal in this Wilderness, as a high frequency (42\%) of Ssensitive species were detected and metal accumulation values were below PNW threshold values indicated for lichen tissues. Regionally, lichen tissue concentrations of N (\%) were amongst the lowest values measured across the seven Wilderness areas included in the baseline 2014 surveys, suggesting that $\mathrm{N}$ deposition in this Wilderness is lower than $\mathrm{N}$ deposition occurring in other areas of the Region. These baseline-monitoring plots are to be revisited every 10 years to assess potential changes in lichen community composition and elemental tissue accumulation. Further, the development of a regional lichen-based gradient model will better our understanding of lichen community response and elemental tissue accumulation in the Intermountain Region.

\section{Additional Information}

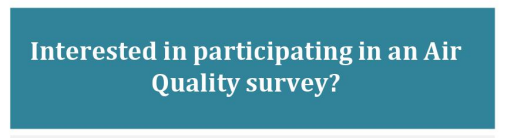

CONTACTS

Air Resource Management National Program Leader: Linda Geiser

(202) 756- 0068

lgeiser@fs.fed.us

Region 4 Wilderness/Wild \& Scenic Rivers Program

Manager:

Sharon Seim

(801) 625 - 5250

sharongseim@fs.fed.us

Reports \& Photos:

Portland State University

Hannah Prather

(971) 340-9748

pratherh@pdx.edu

\section{References and Reading}

Fenn, M.E. L. Geiser, R.Bachman, T.J. Blubaugh, and A. Bytnerowicz. 2007. Atmospheric deposition inputs and effects on lichen chemistry and indicator species in the Columbia River Gorge, USA. Environmental Pollution 146, 77-91.

Geiser, L. 2004. Manual for Monitoring Air Quality Using Lichens on National Forests of the Pacific Northwest. USDA-Forest Service Pacific Northwest Region Technical Paper, R6-NR-AQ-
TP-1-04.126 pp.

Geiser, L.H, S.E. Jovan, D.G Glavich, M.K Porter. 2010. Lichen-based critical loads for atmospheric nitrogen in western Oregon and Washington forests, USA. Environmental Pollution 158, 2412-2421

Geiser, L.H. and P.N. Neitlich. 2007. Air pollution and climate gradients in western Oregon and Washington indicated by epiphytic macrolichens. Environmental Pollution 145, 203-218.

Jovan, S. and B. McCune. 2005. Air-Quality Bioindication in the Greater Central Valley of California, with Epiphytic Macrolichen Communities. Ecological Applications 15, 1712-1726.

Holland, E.A, F.J Dentener, B.H Braswell, J.M Sulzman. 1999. Contemporary and pre-industrial global reactive nitrogen budgets. Biogeochemistry 46, 7-43.

Rogers, P.C., K.D. Moore, and R.J. Ryel. 2009. Aspen succession and nitrogen loading: a case for epiphytic lichens as bioindicators in the Rocky Mountains, USA. Journal of Vegetation Science 20 498-510.

Root, H.T, L.G. Geiser, M.E. Fen, S. Jovan, M.A. Hutton, S. Ahuja, K. Dillman, D. Schirokauer, S. Berryman, J. A. McMurray. 2013. A simple tool for estimating throughfall nitrogen deposition in forests of western North America using lichens. Journal of Forestry and Ecology. Forest Ecology and Management 306, 1-8.

Root. H.T, L.H. Geiser, S. Jovan, P.N. Neitlich. 2015. Epiphytic macrolichen indication of climate and air quality in interior forested mountains of the Pacific Northwest, USA. Ecological Indicators 53, 95-105.

St. Clair, L.L. 1999. A Color Guidebook to Common Rocky Mountain Lichens. Bean Life Science Museum of BYU Publisher. $242 \mathrm{pp}$

National Forest Air Quality and Lichen database and clearinghouse

http://gis.nacse.org/lichenair/index.php 


\section{Box-Death Hollow Wilderness}

\section{Wilderness Plot Establishment}

The purpose of air quality biomonitoring in Wilderness is to assess the status and trends of air pollutants that can affect air quality related values such as the diversity, composition, and health of flora and fauna. The target density for air quality biomonitoring plots in Intermountain Region Wilderness Areas is 1 plot per 20,000 acres. Individual plots are to be re-sampled every 10 years. The following table summarizes the biomonitoring plots established in the baseline year. To learn more about the rationale for lichen monitoring, read the Region 4 Introductory Wilderness Air Quality 2014 Lichen Biomonitoring report. To map plot locations and obtain plot specific data go to http://gis.nacse.org/lichenair/index.php?page=query\&type=plot.

\begin{tabular}{|ccc|}
\hline & & Year Established \\
\hline Plots established & 3 & 2014 \\
Wilderness Acreage & 25,751 & \\
Plots left to meet baseline goal & 0 & \\
\hline
\end{tabular}

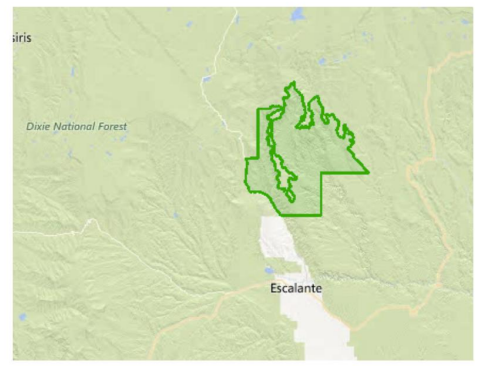

Map of Box-Death Hollow Wilderness Boundary from: Wilderness.net
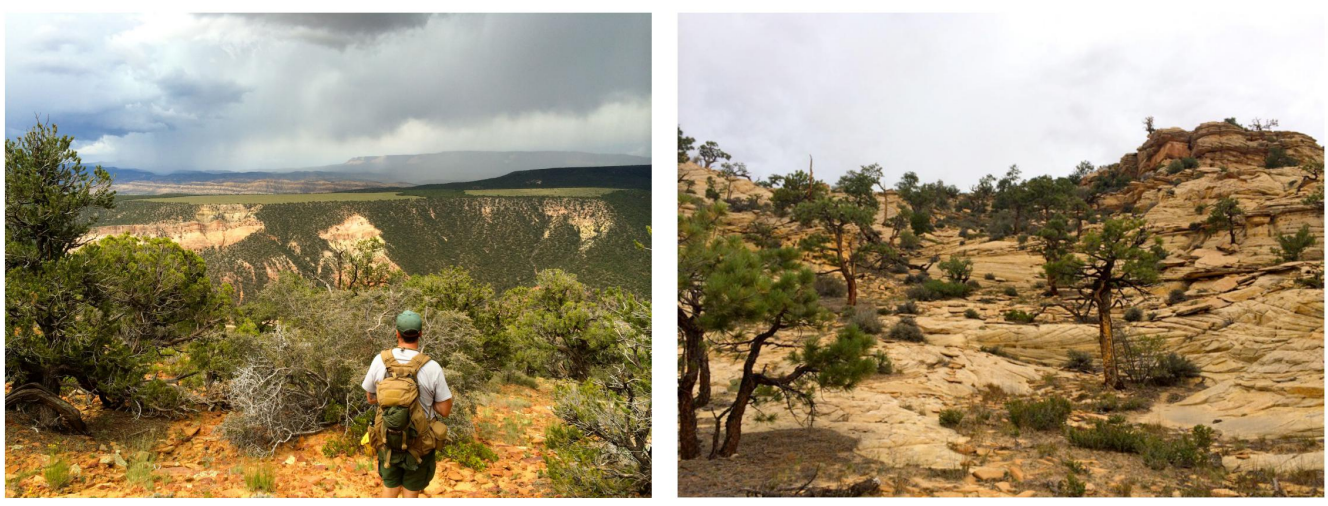


\section{Box-Death Hollow Wilderness}

\section{Lichen Tissue Elemental Concentrations}

The goal of baseline lichen elemental tissue monitoring is to assess current pollutant concentrations and track how they may change, or not change, over time. Pollutant concentrations in epiphytic lichens are correlated with the amounts of pollutants deposited from the atmosphere to vegetation and soils. This table provides baseline elemental values of lichen tissue concentrations for common, abundant epiphytic lichen species found in the Wilderness, shown below as concentration (ppm or \% per dry weight of lichen tissue) of nitrogen, sulfur, arsenic, cadmium, chromium, copper, nickel, lead and zinc, summarized by species. All values were related to mean regional threshold values determined for lichen tissues in the PNW Region; those exceeding threshold values for clean sites are highlighted in bold typeface. Further discussion of lichen $\mathrm{N}$ and S concentrations (\%) are provided in the appendix. Determination of these values to define clean site threshold values specific to the Intermountain Region requires development of a regional lichen-based gradient model.

\begin{tabular}{|c|c|c|c|c|c|c|c|c|c|}
\hline & $\begin{array}{l}\mathrm{N} \\
\% \\
\end{array}$ & $\begin{array}{l}\mathbf{S} \\
\%\end{array}$ & $\begin{array}{c}\text { As } \\
\text { ppm }\end{array}$ & $\begin{array}{c}\text { Cd } \\
\mathrm{ppm}\end{array}$ & $\begin{array}{c}\mathrm{Cr} \\
\mathrm{ppm}\end{array}$ & $\begin{array}{c}\mathrm{Cu} \\
\mathrm{ppm}\end{array}$ & $\begin{array}{c}\mathrm{Ni} \\
\mathrm{ppm}\end{array}$ & $\begin{array}{c}\mathrm{Pb} \\
\mathrm{ppm}\end{array}$ & $\begin{array}{c}\mathrm{Zn} \\
\mathrm{ppm}\end{array}$ \\
\hline \multicolumn{10}{|c|}{ Melanelia subolivacea } \\
\hline \multicolumn{10}{|l|}{$n=2$} \\
\hline mean & 1.5 & na & 0.4 & 0.1 & 0.8 & 4.9 & 0.5 & 2.7 & 17.8 \\
\hline $\min$ & 1.4 & na & 0.4 & 0.1 & 0.5 & 4.7 & 0.4 & 1.8 & 16.4 \\
\hline $\max$ & 1.5 & na & 0.5 & 0.1 & 1.0 & 5.1 & 0.6 & 3.6 & 19.1 \\
\hline \multicolumn{10}{|c|}{ Xanthomendoza montana } \\
\hline \multicolumn{10}{|l|}{$n=2$} \\
\hline mean & 2.1 & 0.2 & 0.6 & 0.1 & 0.9 & 5.0 & 0.5 & 2.1 & 39.2 \\
\hline $\min$ & 1.9 & 0.2 & 0.6 & 0.1 & 0.5 & 4.0 & 0.2 & 0.7 & 37.5 \\
\hline $\max$ & 2.2 & 0.2 & 0.7 & 0.2 & 1.4 & 5.9 & 0.8 & 3.5 & 40.9 \\
\hline \multicolumn{10}{|c|}{ Xanthoparmelia plittii } \\
\hline \multicolumn{10}{|l|}{$n=3$} \\
\hline mean & 1.0 & 0.1 & 0.5 & 0.2 & 1.2 & 4.1 & 0.5 & 3.1 & 14.9 \\
\hline sd & 0.2 & 0.0 & 0.2 & 0.0 & 0.5 & 0.3 & 0.1 & 1.2 & 3.2 \\
\hline $\min$ & 0.8 & 0.1 & 0.3 & 0.1 & 0.8 & 3.8 & 0.4 & 1.8 & 11.2 \\
\hline $\max$ & 1.1 & 0.1 & 0.7 & 0.2 & 1.7 & 4.3 & 0.6 & 4.1 & 17.2 \\
\hline
\end{tabular}




\section{Box-Death Hollow Wilderness}

\section{Community Composition \& Species Sensitivities}

Composition of the epiphytic macrolichen community (non-crustose species on woody substrates) within a plot determines that plot's position along larger regional pollution and climate gradients. The table below summarizes lichen species observed in all plots established in the baseline year, including crustose and ground dwelling species voluntarily collected by surveyors, as well as epiphytic species used in air quality tissue analyses. In lieu of a regional lichen-based gradient model, lichen sensitivity ratings were categorized according to the sensitivity ratings for $\mathrm{N}$ and $\mathrm{S}$ pollutants derived from species distributions in the western United States (Geiser \& Root, in prep). Pollution sensitivity ratings: $\mathbf{M S}=$ most sensitive, $\mathbf{S}=\mathbf{s e n s i t i v e , ~} \mathbf{I}=$ intermediate, $\mathbf{T}=$ tolerant, $\mathbf{U}=$ unknown. For plot specific species lists for this Wilderness area go to: http://gis.nacse.org/lichenair/index.php?page=query\&type=community.

\begin{tabular}{lcc} 
Species Name & N-Sensitivity & S-Sensitivity \\
\hline Leptogium saturninum & $\mathrm{T}$ & $\mathrm{S}$ \\
Melanelia subolivacea & $\mathrm{U}$ & $\mathrm{S}$ \\
Melanohalea elegantula & $\mathrm{S}$ & $\mathrm{S}$ \\
Melanohalea exasperatula & $\mathrm{S}$ & $\mathrm{S}$ \\
Physcia adscendens & $\mathrm{T}$ & $\mathrm{T}$ \\
Rhizoplaca melanophthalma & $\mathrm{U}$ & $\mathrm{U}$ \\
Usnea lapponica & $\mathrm{S}$ & $\mathrm{S}$ \\
Xanthomendoza montana & $\mathrm{U}$ & $\mathrm{U}$ \\
Xanthoparmelia plittii & $\mathrm{U}$ & $\mathrm{U}$ \\
\hline Total species richness & &
\end{tabular}

Elevated nitrogen and sulfur deposition has distinct effects on epiphytic lichen community composition. Clean air plots with low nitrogen and/or sulfur deposition have a higher frequency of sensitive species than tolerant species. The proportions of species indicative of nitrogen and sulfur deposition for this Wilderness are listed in the table below. The high frequency of $\mathrm{N}$-sensitive species (33\%) and S-sensitive species (56\%) suggests minimal air pollution related impacts are occurring in this Wilderness. Additionally, lichen tissue concentrations of $\mathrm{N}(\%)$ collected in this Wilderness were among the lowest values observed across the seven Wilderness areas surveyed in the baseline year.

\begin{tabular}{lcc} 
& $\begin{array}{c}\text { Frequency (\%) } \\
\text { N-Sensitive }\end{array}$ & $\begin{array}{c}\text { Frequency (\%) } \\
\text { S-Sensitive }\end{array}$ \\
\hline Most Sensitive & 0 & 0 \\
Sensitive & $\mathbf{3 3}$ & $\mathbf{5 6}$ \\
Intermediate & 0 & 0 \\
Tolerant & 22 & 11 \\
Unknown & 45 & 33 \\
\hline
\end{tabular}




\section{Box-Death Hollow Wilderness}

\section{Baseline Monitoring Summary}

The baseline information provided here suggests an intact lichen flora, typical of other lichen floras of the Intermountain Region and the greater central valley of California. The high frequency of N-sensitive species $(33 \%)$ and S-sensitive species (56\%) suggests minimal air pollution related impacts are occurring in this Wilderness. Further, metal accumulation values were below PNW threshold values indicated for lichen tissues. Regionally, lichen tissue concentrations of N (\%) were amongst the lowest values measured across the seven Wilderness areas included in the baseline 2014 surveys, suggesting that $\mathrm{N}$ deposition in this Wilderness is lower than rates of $\mathrm{N}$-deposition occurring in other areas of the survey area. These baselinemonitoring plots are to be revisited every 10 years to assess potential changes in lichen community composition and elemental tissue accumulation. Further, the development of a regional lichen gradient model will better our understanding of lichen community response and elemental tissue accumulation in the larger Intermountain Region.

\section{Additional Information}

\section{References and Reading}

Interested in participating in an Air
Quality survey?
CONTACT S
Air Resource Management
National Program Leader:
Linda Geiser
(202) 756- 0068
lgeiser@fs.fed.us
Region 4 Wilderness/Wild \&
Scenic Rivers Program
Manager:
Sharon Seim
(801) 625 - 5250
sharongseim@fs.fed.us
Reports \& Photos:
Portland State University
Hannah Prather
(971) 340-9748
pratherh@pdx.edu

Fenn, M.E. L. Geiser, R.Bachman, T.J. Blubaugh, and A. Bytnerowicz. 2007. Atmospheric deposition inputs and effects on lichen chemistry and indicator species in the Columbia River
Gorge, USA. Environmental Pollution 146, 77-91.

Geiser, L. 2004. Manual for Monitoring Air Quality Using Lichens on National Forests of the Pacific Northwest. USDA-Forest Service Pacific Northwest Region Technical Paper, R6-NR-AQTP-1-04.126 pp

Geiser, L.H, S.E. Jovan, D.G Glavich, M.K Porter. 2010. Lichen-based critical loads for atmospheric nitrogen in western Oregon and Washington forests, USA. Environmental Pollution 158, 2412-2421.

Geiser, L.H. and P.N. Neitlich. 2007. Air pollution and climate gradients in western Oregon and Washington indicated by epiphytic macrolichens. Environmental Pollution 145, 203-218.

Jovan, S. and B. McCune. 2005. Air-Quality Bioindication in the Greater Central Valley of California, with Epiphytic Macrolichen Communities. Ecological Applications 15, 1712-1726.

Holland, E.A, F.J Dentener, B.H Braswell, J.M Sulzman. 1999. Contemporary and pre-industrial global reactive nitrogen budgets. Biogeochemistry 46, 7-43.

Rogers, P.C., K.D. Moore, and R.J. Ryel. 2009. Aspen succession and nitrogen loading: a case for epiphytic lichens as bioindicators in the Rocky Mountains, USA. Journal of Vegetation Science 20, 498-510.

Root, H.T, L.G. Geiser, M.E. Fen, S. Jovan, M.A. Hutton, S. Ahuja, K. Dillman, D. Schirokauer, S. Berryman, J. A. McMurray. 2013. A simple tool for estimating throughfall nitrogen deposition in forests of western North America using lichens. Journal of Forestry and Ecology. Forest Ecology and Management 306, 1-8.

Root. H.T, L.H. Geiser, S. Jovan, P.N. Neitlich. 2015. Epiphytic macrolichen indication of climate and air quality in interior forested mountains of the Pacific Northwest, USA. Ecological Indicators 53, 95-105.

St. Clair, L.L. 1999. A Color Guidebook to Common Rocky Mountain Lichens. Bean Life Science Museum of BYU Publisher. 242 pp

National Forest Air Quality and Lichen database and clearinghouse http://gis.nacse.org/lichenair/index.php. 


\section{Cottonwood Forest Wilderness}

\section{Wilderness Plot Establishment}

The purpose of air quality biomonitoring in Wilderness is to assess the status and trends of air pollutants that can affect air quality related values such as the diversity, composition, and health of flora and fauna. The target density for air quality biomonitoring plots in Intermountain Region Wilderness Areas is 1 plot per 20,000 acres. Individual plots are to be re-sampled every 10 years. The following table summarizes the biomonitoring plots established in the baseline year. To learn more about the rationale for lichen monitoring, read the Region 4 Introductory Wilderness Air Quality 2014 Lichen Biomonitoring report. To map plot locations and obtain plot specific data go to

http://gis.nacse.org/lichenair/index.php?page=query\&type=plot.

\begin{tabular}{|ccc|}
\hline & & Year Established \\
\hline \hline Plots established & 1 & 2014 \\
Wilderness Acreage & 2,643 & \\
Plots left to meet baseline goal & 0 & \\
\hline
\end{tabular}

\section{Lichen Tissue Elemental Concentrations}

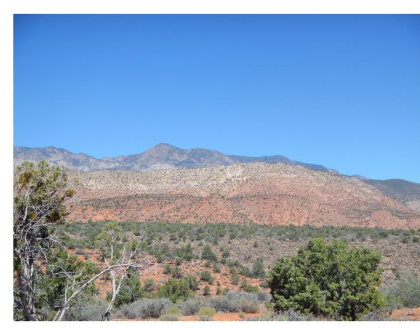

The goal of baseline lichen elemental tissue monitoring is to assess current pollutant concentrations and track how they may change, or not change, over time. Pollutant concentrations in epiphytic lichens are correlated with the amounts of pollutants deposited from the atmosphere to vegetation and soils. This table provides baseline elemental values of lichen tissue concentrations for common, abundant epiphytic lichen species found in the Wilderness, shown below as concentration (ppm or \% per dry weight of lichen tissue) of nitrogen, sulfur, arsenic, cadmium, chromium, copper, nickel, lead and zinc, summarized by species. All values were related to mean regional threshold values determined for lichen tissues in the PNW Region; those exceeding threshold values for clean sites are highlighted in bold typeface. Further discussion of lichen $\mathrm{N}$ and $\mathrm{S}$ concentrations (\%) are provided in the appendix. Determination of these values to define clean site threshold values specific to the Intermountain Region requires development of a regional lichen-based gradient model.

\begin{tabular}{|c|c|c|c|c|c|c|c|c|c|}
\hline & $\begin{array}{l}\mathrm{N} \\
\%\end{array}$ & $\begin{array}{l}\mathrm{S} \\
\%\end{array}$ & $\begin{array}{l}\text { As } \\
\text { ppm }\end{array}$ & $\begin{array}{l}\mathrm{Cd} \\
\mathrm{ppm}\end{array}$ & $\begin{array}{c}\mathrm{Cr} \\
\mathrm{ppm}\end{array}$ & $\begin{array}{c}\mathrm{Cu} \\
\mathrm{ppm}\end{array}$ & $\begin{array}{c}\mathrm{Ni} \\
\mathrm{ppm}\end{array}$ & $\begin{array}{c}\mathrm{Pb} \\
\mathrm{ppm}\end{array}$ & $\begin{array}{c}\mathrm{Zn} \\
\mathrm{ppm}\end{array}$ \\
\hline \multicolumn{10}{|c|}{ Rhizoplaca melanophthalma } \\
\hline \multicolumn{10}{|l|}{$n=2$} \\
\hline mean & 1.8 & 0.1 & 0.6 & 0.2 & 1.6 & 5.0 & 1.0 & 5.3 & 15.4 \\
\hline $\min$ & 1.8 & 0.1 & 0.6 & 0.2 & 1.3 & 4.9 & 0.8 & 5.1 & 14.6 \\
\hline $\max$ & 1.9 & 0.1 & 0.6 & 0.2 & 1.9 & 5.1 & 1.2 & 5.5 & 16.3 \\
\hline
\end{tabular}




\section{Cottonwood Forest Wilderness}

\section{Community Composition \& Species Sensitivities}

Composition of the epiphytic macrolichen community (non-crustose species on woody substrates) within a plot determines that plot's position along larger regional pollution and climate gradients. The table below summarizes lichen species observed in all plots established in the baseline year, including crustose and ground dwelling species voluntarily collected by surveyors, as well as epiphytic species used in air quality tissue analyses. In lieu of a regional lichen-based gradient model, lichen sensitivity ratings were categorized according to the sensitivity ratings for $\mathrm{N}$ and $\mathrm{S}$ pollutants derived from species distributions in the western United States (Geiser \& Root, in prep). Pollution sensitivity ratings: $\mathbf{M S}=\mathbf{m o s t}$ sensitive, $\mathbf{S}=\mathbf{s e n s i t i v e , ~} \mathbf{I}=$ intermediate, $\mathbf{T}=$ tolerant, $\mathbf{U}=$ unknown. For plot specific species lists for this Wilderness area go to: http://gis.nacse.org/lichenair/index.php?page=query\&type=community.

\begin{tabular}{lcc} 
Species Name & N-Sensitivity & S-Sensitivity \\
\hline Candelariella antennaria & $\mathrm{U}$ & $\mathrm{U}$ \\
Physcia dubia & $\mathrm{I}$ & $\mathrm{S}$ \\
Physciella melanchra & $\mathrm{T}$ & $\mathrm{S}$ \\
Rhizoplaca melanophthalma & $\mathrm{U}$ & $\mathrm{U}$ \\
Xanthomendoza fallax & $\mathrm{T}$ & $\mathrm{U}$ \\
\hline Total species richness & 5 &
\end{tabular}

Elevated nitrogen and sulfur deposition has distinct effects on epiphytic lichen community composition. Clean air plots with low nitrogen and/or sulfur deposition have a higher frequency of sensitive species than tolerant species. The proportions of species indicative of nitrogen and sulfur deposition for this Wilderness are listed in the table below. The high frequency of $\mathrm{N}$-tolerant and $\mathrm{N}$-intermediate species $(60 \%$, collectively) suggests signs of elevated $\mathrm{N}$ deposition are occurring in this Wilderness. Yet, the high frequency of S-sensitive species (40\%) detected suggests that sulfur deposition is minimal.

\begin{tabular}{lcc} 
& $\begin{array}{c}\text { Frequency (\%) } \\
\text { N-Sensitive }\end{array}$ & $\begin{array}{c}\text { Frequency }(\%) \\
\text { S- Sensitive }\end{array}$ \\
\hline Most Sensitive & 0 & 0 \\
Sensitive & 0 & $\mathbf{4 0}$ \\
Intermediate & 20 & 0 \\
Tolerant & $\mathbf{4 0}$ & 0 \\
Unknown & 40 & 60 \\
\hline
\end{tabular}

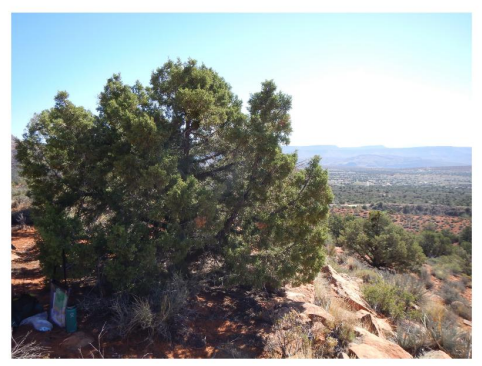




\section{Cottonwood Forest Wilderness}

\section{Baseline Monitoring Summary}

The baseline information provided here suggests an intact lichen flora, typical of other lichen floras of the Intermountain Region and the greater central valley of California. The high proportion of N-tolerant and Nintermediate species ( $60 \%$, collectively) detected suggests that sensitive lichen communities are indicating signs of elevated $\mathrm{N}$ deposition in this Wilderness. Yet, sulfur deposition appears minimal in this Wilderness, as a high frequency (40\%) of S-sensitive species were detected. Metal accumulation values were below PNW threshold values indicated for lichen tissues. Species richness of lichen epiphytes was amongst the lowest observed across the seven Wilderness areas included in the baseline 2014 surveys, likely related to the lack of larger substrates in the survey area. These baseline-monitoring plots are to be revisited every 10 years to assess potential changes in lichen community composition and elemental tissue accumulation. Further, the development of a regional lichen gradient model will better our understanding of lichen community response and elemental tissue accumulation in the larger Intermountain Region.

\section{Additional Information}

\section{References and Reading}

\section{Interested in participating in an Air} Quality survey?

CONTACTS

Air Resource Management National Program Leader:

Linda Geiser

(202) 756- 0068

lgeiser@fs.fed.us

Region 4 Wilderness/Wild \& Scenic Rivers Program

Manager:

Sharon Seim

(801) 625 - 5250

sharongseim@fs.fed.us

Reports \& Photos:

Portland State University

Hannah Prather

(971) 340-9748

pratherh@pdx.edu
Fenn, M.E. L. Geiser, R.Bachman, T.J. Blubaugh, and A. Bytnerowicz. 2007. Atmospheric deposition inputs and effects on lichen chemistry and indicator species in the Columbia River Gorge, USA. Environmental Pollution 146, 77-91.

Geiser, L. 2004. Manual for Monitoring Air Quality Using Lichens on National Forests of the Pacific Northwest. USDA-Forest Service Pacific Northwest Region Technical Paper, R6-NR-AQTP-1-04.126 pp

Geiser, L.H, S.E. Jovan, D.G Glavich, M.K Porter. 2010. Lichen-based critical loads for atmospheric nitrogen in western Oregon and Washington forests, USA. Environmental Pollution 158, 2412-2421

Geiser, L.H. and P.N. Neitlich. 2007. Air pollution and climate gradients in western Oregon and Washington indicated by epiphytic macrolichens. Environmental Pollution 145, 203-218.

Jovan, S. and B. McCune. 2005. Air-Quality Bioindication in the Greater Central Valley of California, with Epiphytic Macrolichen Communities. Ecological Applications 15, 1712-1726.

Holland, E.A, F.J Dentener, B.H Braswell, J.M Sulzman. 1999. Contemporary and pre-industrial global reactive nitrogen budgets. Biogeochemistry 46, 7-43.

Rogers, P. 2007. Factors Influencing Epiphytic Lichen Communities in Aspen-Associated Forests of the Bear River Range, Idaho and Utah Logan, UT: Utah State University. 166p. Dissertation.

Rogers, P.C., K.D. Moore, and R.J. Ryel, 2009. Aspen succession and nitrogen loading: a case for epiphytic lichens as bioindicators in the Rocky Mountains, USA. Journal of Vegetation Science 20 498-510.

Root, H.T, L.G. Geiser, M.E. Fen, S. Jovan, M.A. Hutton, S. Ahuja, K. Dillman, D. Schirokauer, S. Berryman, J. A. McMurray. 2013. A simple tool for estimating throughfall nitrogen deposition in forests of western North America using lichens. Journal of Forestry and Ecology. Forest Ecology and Management 306, 1-8.

Root. H.T, L.H. Geiser, S. Jovan, P.N. Neitlich. 2015. Epiphytic macrolichen indication of climate and air quality in interior forested mountains of the Pacific Northwest, USA. Ecological Indicators 53, 95-105.

St. Clair, L.L. 1999. A Color Guidebook to Common Rocky Mountain Lichens. Bean Life Science Museum of BYU Publisher. $242 \mathrm{pp}$.

National Forest Air Quality and Lichen database and clearinghouse http://gis.nacse.org/lichenair/index.php. 


\section{Dark Canyon Wilderness}

\section{Wilderness Plot Establishment}

The purpose of air quality biomonitoring in Wilderness is to assess the status and trends of air pollutants that can affect air quality related values such as the diversity, composition, and health of flora and fauna. The target density for air quality biomonitoring plots in Intermountain Region Wilderness Areas is 1 plot per 20,000 acres. Individual plots are to be re-sampled every 10 years. The following table summarizes the biomonitoring plots established in the baseline year. To learn more about the rationale for lichen monitoring, read the Region 4 Introductory Wilderness Air Quality 2014 Lichen Biomonitoring report. To map plot locations and obtain plot specific data go to

http://gis.nacse.org/lichenair/index.php?page=query\&type=plot.

\begin{tabular}{|ccc|}
\hline & & Year Established \\
\hline \hline Plots established & 3 & 2014 \\
Wilderness Acreage & 46,353 & \\
Plots left to meet baseline goal & 0 & \\
\hline
\end{tabular}
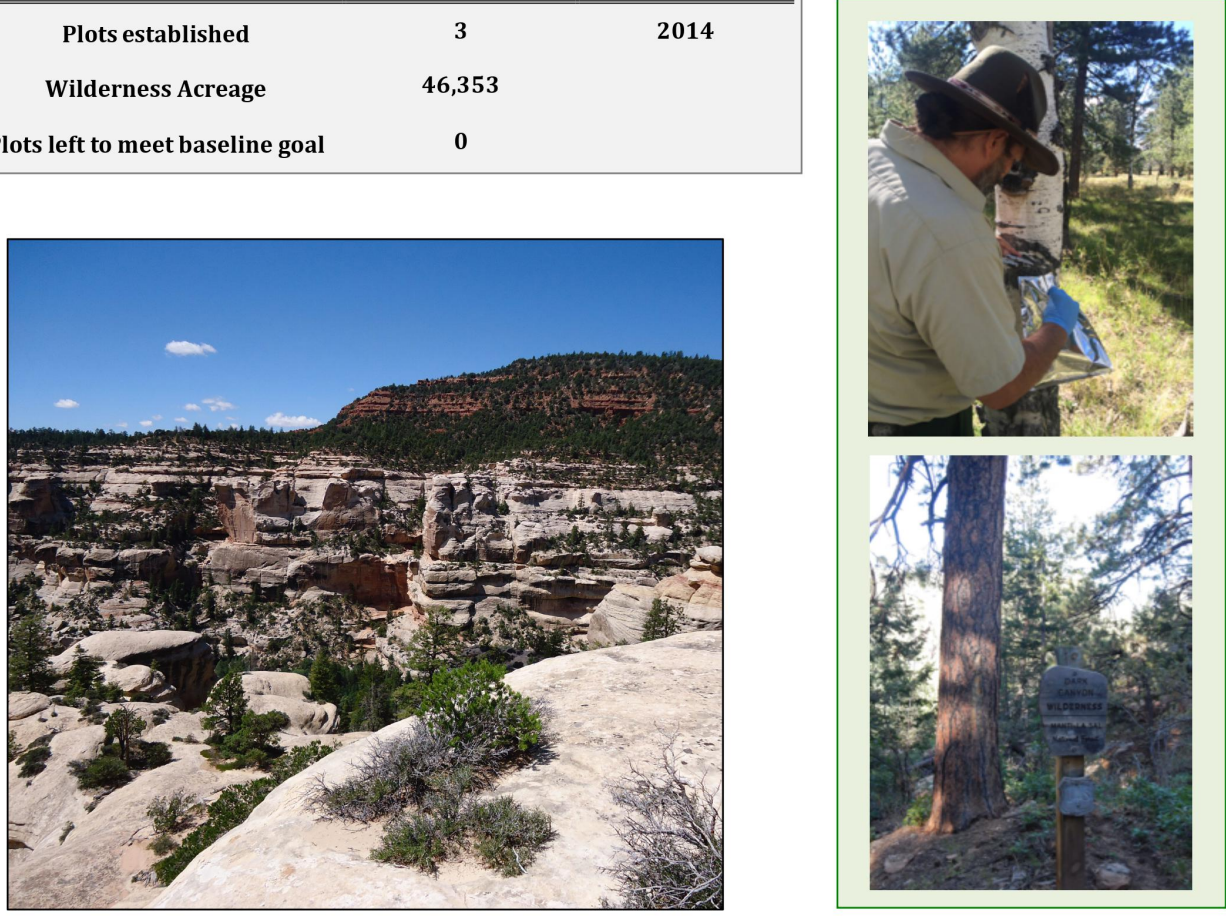

Photos courtesy of B. Murdock \& H. Prather 


\section{Dark Canyon Wilderness}

\section{Lichen Tissue Elemental Concentrations}

The goal of baseline lichen elemental tissue monitoring is to assess current pollutant concentrations and track how they may change, or not change, over time. Pollutant concentrations in epiphytic lichens are correlated with the amounts of pollutants deposited from the atmosphere to vegetation and soils. This table provides baseline elemental values of lichen tissue concentrations for common, abundant epiphytic lichen species found in the Wilderness, shown below as concentration (ppm or \% per dry weight of lichen tissue) of nitrogen, sulfur, arsenic, cadmium, chromium, copper, nickel, lead and zinc, summarized by species. All values were related to mean regional threshold values determined for lichen tissues in the PNW Region; those exceeding threshold values for clean sites are highlighted in bold typeface. Further discussion of lichen $\mathrm{N}$ and S concentrations (\%) are provided in the appendix. Determination of these values to define clean site threshold values specific to the Intermountain Region requires development of a regional lichen-based gradient model.

\begin{tabular}{|c|c|c|c|c|c|c|c|c|c|}
\hline & $\begin{array}{l}\mathrm{N} \\
\%\end{array}$ & $\begin{array}{l}\mathrm{s} \\
\%\end{array}$ & $\begin{array}{l}\text { As } \\
\mathrm{ppm}\end{array}$ & $\begin{array}{c}\mathrm{Cd} \\
\mathrm{ppm}\end{array}$ & $\begin{array}{c}\mathrm{Cr} \\
\mathrm{ppm}\end{array}$ & $\begin{array}{c}\mathrm{Cu} \\
\mathrm{ppm}\end{array}$ & $\begin{array}{c}\mathrm{Ni} \\
\mathrm{ppm}\end{array}$ & $\begin{array}{c}\mathrm{Pb} \\
\mathrm{ppm}\end{array}$ & $\begin{array}{l}\mathrm{Zn} \\
\mathrm{ppm}\end{array}$ \\
\hline \multicolumn{10}{|c|}{ Melanelia subolivacea } \\
\hline \multicolumn{10}{|l|}{$n=2$} \\
\hline mean & 1.8 & 0.2 & 0.9 & 0.1 & 1.9 & 5.0 & 0.9 & 1.9 & 13.2 \\
\hline $\min$ & 1.7 & 0.2 & 0.7 & 0.1 & 1.3 & 4.6 & 0.5 & 1.3 & 11.8 \\
\hline $\max$ & 1.8 & 0.2 & 1.0 & 0.1 & 2.5 & 5.4 & 1.2 & 2.5 & 14.7 \\
\hline \multicolumn{10}{|c|}{ Physcia aipolia } \\
\hline \multicolumn{10}{|l|}{$n=1$} \\
\hline mean & 2.7 & 0.3 & 0.9 & 0.1 & 2.0 & 4.9 & 0.8 & 1.3 & 12.1 \\
\hline \multicolumn{10}{|c|}{ Xanthomendoza montana } \\
\hline \multicolumn{10}{|l|}{$n=2$} \\
\hline mean & 2.4 & 0.2 & 0.6 & 0.2 & 1.5 & 5.5 & 1.0 & 2.1 & 37.1 \\
\hline $\min$ & 2.3 & 0.2 & 0.4 & 0.1 & 1.3 & 5.2 & 1.0 & 1.5 & 28.1 \\
\hline $\max$ & 2.6 & 0.2 & 0.9 & 0.3 & 1.7 & 5.8 & 1.0 & 2.8 & 46.1 \\
\hline
\end{tabular}
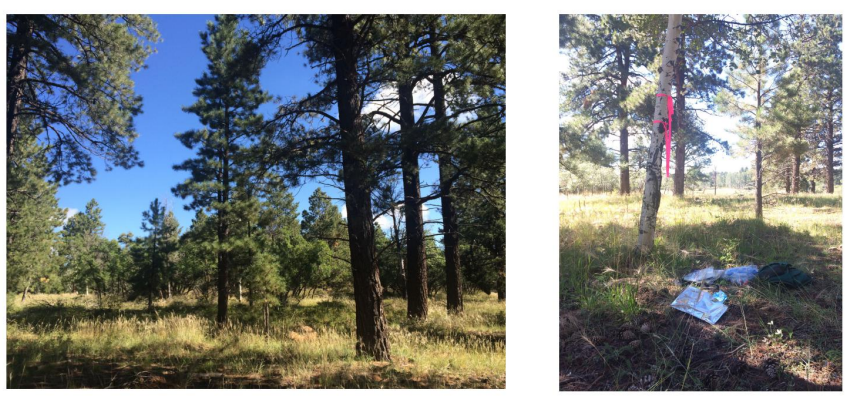


\section{Dark Canyon Wilderness}

\section{Community Composition \& Species Sensitivities}

Composition of the epiphytic macrolichen community (non-crustose species on woody substrates) within a plot determines that plot's position along larger regional pollution and climate gradients. The table below summarizes lichen species observed in all plots established in the baseline year, including crustose and ground dwelling species voluntarily collected by surveyors, as well as epiphytic species used in air quality tissue analyses. In lieu of a regional lichen-based gradient model, lichen sensitivity ratings were categorized according to the sensitivity ratings for $\mathrm{N}$ and $\mathrm{S}$ pollutants derived from species distributions in the western United States (Geiser \& Root, in prep). Pollution sensitivity ratings: $\mathbf{M S}=$ most sensitive, $\mathbf{S}=$ sensitive, I = intermediate, $\mathbf{T}=$ tolerant, $\mathbf{U}=$ unknown. For plot specific species lists for this Wilderness area go to: http://gis.nacse.org/lichenair/index.php?page=query\&type=community.

\begin{tabular}{lcc} 
Species Name & N-Sensitivity & S-Sensitivity \\
\hline Candelariella rosulans & $\mathrm{U}$ & $\mathrm{U}$ \\
Flavopunctelia soredica & $\mathrm{I}$ & $\mathrm{S}$ \\
Melanelia subolivacea & $\mathrm{U}$ & $\mathrm{S}$ \\
Melanohalea elegantula & $\mathrm{S}$ & $\mathrm{S}$ \\
Physcia adscendens & $\mathrm{T}$ & $\mathrm{T}$ \\
Physcia aipolia & $\mathrm{T}$ & $\mathrm{I}$ \\
Physcia stellaris & $\mathrm{I}$ & $\mathrm{T}$ \\
Physciella melanchra & $\mathrm{T}$ & $\mathrm{S}$ \\
Physciella sp. & $\mathrm{U}$ & $\mathrm{U}$ \\
Ramalina sinensis & $\mathrm{I}$ & $\mathrm{S}$ \\
Usnea hirta & $\mathrm{I}$ & $\mathrm{S}$ \\
Usnea lapponica & $\mathrm{S}$ & $\mathrm{S}$ \\
Xanthomendoza fallax & $\mathrm{T}$ & $\mathrm{U}$ \\
Xanthomendoza montana & $\mathrm{U}$ & $\mathrm{U}$ \\
\hline Total species richness & &
\end{tabular}

Elevated nitrogen and sulfur deposition has distinct effects on epiphytic lichen community composition. Clean air plots with low nitrogen and/or sulfur deposition have a higher frequency of sensitive species than tolerant species. The proportions of species indicative of nitrogen or sulfur deposition for this Wilderness are listed in the table below. The frequency of $\mathrm{N}$-tolerant and $\mathrm{N}$-intermediate species (29\%, respectively) suggests early indication of elevated $\mathrm{N}$ deposition in this Wilderness. Yet, the high frequency of S-sensitive species $(50 \%)$ detected suggests that sulfur deposition is minimal.

\begin{tabular}{lcc} 
& $\begin{array}{c}\text { Frequency (\%) } \\
\text { N-Sensitive }\end{array}$ & $\begin{array}{c}\text { Frequency (\%) } \\
\text { S-Sensitive }\end{array}$ \\
\hline Most Sensitive & 0 & 0 \\
Sensitive & 13 & $\mathbf{5 0}$ \\
Intermediate & $\mathbf{2 9}$ & 7 \\
Tolerant & $\mathbf{2 9}$ & 14 \\
Unknown & 29 & 29 \\
\hline
\end{tabular}




\section{Dark Canyon Wilderness}

\section{Baseline Monitoring Summary}

The baseline information provided here suggests an intact lichen flora, typical of other lichen floras of the Intermountain Region and the greater central valley of California. The frequency of N-tolerant and $\mathrm{N}$ intermediate species (29\%, respectively) suggests that sensitive lichen communities may be indicating early signs of elevated $\mathrm{N}$ deposition in this Wilderness. Yet, sulfur deposition appears minimal, as a high frequency (50\%) of S-sensitive species were detected. Metal accumulation values were below PNW threshold values indicated for lichen tissues. These baseline-monitoring plots are to be revisited every 10 years to assess potential changes in lichen community composition and elemental tissue accumulation. Further, the development of a regional lichen gradient model will better our understanding of lichen community response and elemental tissue accumulation in the larger Intermountain Region.

\section{Additional Information}

\section{Interested in participating in an Air Quality survey?}

CONTACTS

Air Resource Management National Program Leader Linda Geiser (202) 756- 0068 lgeiser@fs.fed.us

Region 4 Wilderness/Wild \& Scenic Rivers Program

Manager:

Sharon Seim (801) 625 - 5250 sharongseim@fs.fed.us

Reports produced by: Portland State University Hannah Prather (971) 340-9748 pratherh@pdx.edu

\section{References and Reading}

Fenn, M.E. L. Geiser, R.Bachman, T.J. Blubaugh, and A. Bytnerowicz. 2007. Atmospheric deposition inputs and effects on lichen chemistry and indicator species in the Columbia Rive Gorge, USA. Environmental Pollution 146, 77-91.

Geiser, L. 2004. Manual for Monitoring Air Quality Using Lichens on National Forests of the Pacific Northwest. USDA-Forest Service Pacific Northwest Region Technical Paper, R6-NR-AQTP-1-04.126 pp.

Geiser, L.H, S.E. Jovan, D.G Glavich, M.K Porter. 2010. Lichen-based critical loads for atmospheric nitrogen in western Oregon and Washington forests, USA. Environmental Pollution 158, 2412-2421.

Geiser, L.H. and P.N. Neitlich. 2007. Air pollution and climate gradients in western Oregon and Washington indicated by epiphytic macrolichens. Environmental Pollution 145, 203-218.

Jovan, S. and B. McCune. 2005. Air-Quality Bioindication in the Greater Central Valley of California, with Epiphytic Macrolichen Communities. Ecological Applications 15, 1712-1726.

Holland, E.A, F.J Dentener, B.H Braswell, J.M Sulzman. 1999. Contemporary and pre-industrial global reactive nitrogen budgets. Biogeochemistry 46, 7-43.

Rogers, P. 2007. Factors Influencing Epiphytic Lichen Communities in Aspen-Associated Forests of the Bear River Range, Idaho and Utah Logan, UT: Utah State University. 166p. Dissertation.

Rogers, P.C., K.D. Moore, and R.J. Ryel. 2009. Aspen succession and nitrogen loading: a case for epiphytic lichens as bioindicators in the Rocky Mountains, USA. Journal of Vegetation Science 20 498-510.

Root, H.T, L.G. Geiser, M.E. Fen, S. Jovan, M.A. Hutton, S. Ahuja, K. Dillman, D. Schirokauer, S. Berryman, J. A. McMurray. 2013. A simple tool for estimating throughfall nitrogen deposition in forests of western North America using lichens. Journal of Forestry and Ecology. Forest Ecology and Management 306, 1-8.

Root. H.T, L.H. Geiser, S. Jovan, P.N. Neitlich. 2015. Epiphytic macrolichen indication of climate and air quality in interior forested mountains of the Pacific Northwest, USA. Ecological Indicators 53, 95-105.

St. Clair, L.L. 1999. A Color Guidebook to Common Rocky Mountain Lichens. Bean Life Science Museum of BYU Publisher. $242 \mathrm{pp}$.

National Forest Air Quality and Lichen database and clearinghouse

http://gis.nacse.org/lichenair/index.php. 


\section{Lone Peak Wilderness}

\section{Wilderness Plot Establishment}

The purpose of air quality biomonitoring in Wilderness is to assess the status and trends of air pollutants that can affect air quality related values such as the diversity, composition, and health of flora and fauna. The target density for air quality biomonitoring plots in Intermountain Region Wilderness Areas is 1 plot per 20,000 acres. Individual plots are to be re-sampled every 10 years. The following table summarizes the biomonitoring plots established in the baseline year. To learn more about the rationale for lichen monitoring, read the Region 4 Introductory Wilderness Air Quality 2014 Lichen Biomonitoring report. To map plot locations and obtain plot specific data go to

http://gis.nacse.org/lichenair/index.php?page=query\&type=plot.

\begin{tabular}{|ccc|}
\hline & & Year Established \\
\hline \hline Plots established & 2 & 2014 \\
Wilderness Acreage & 30,088 & \\
Plots left to meet baseline goal & 0 & \\
\hline
\end{tabular}
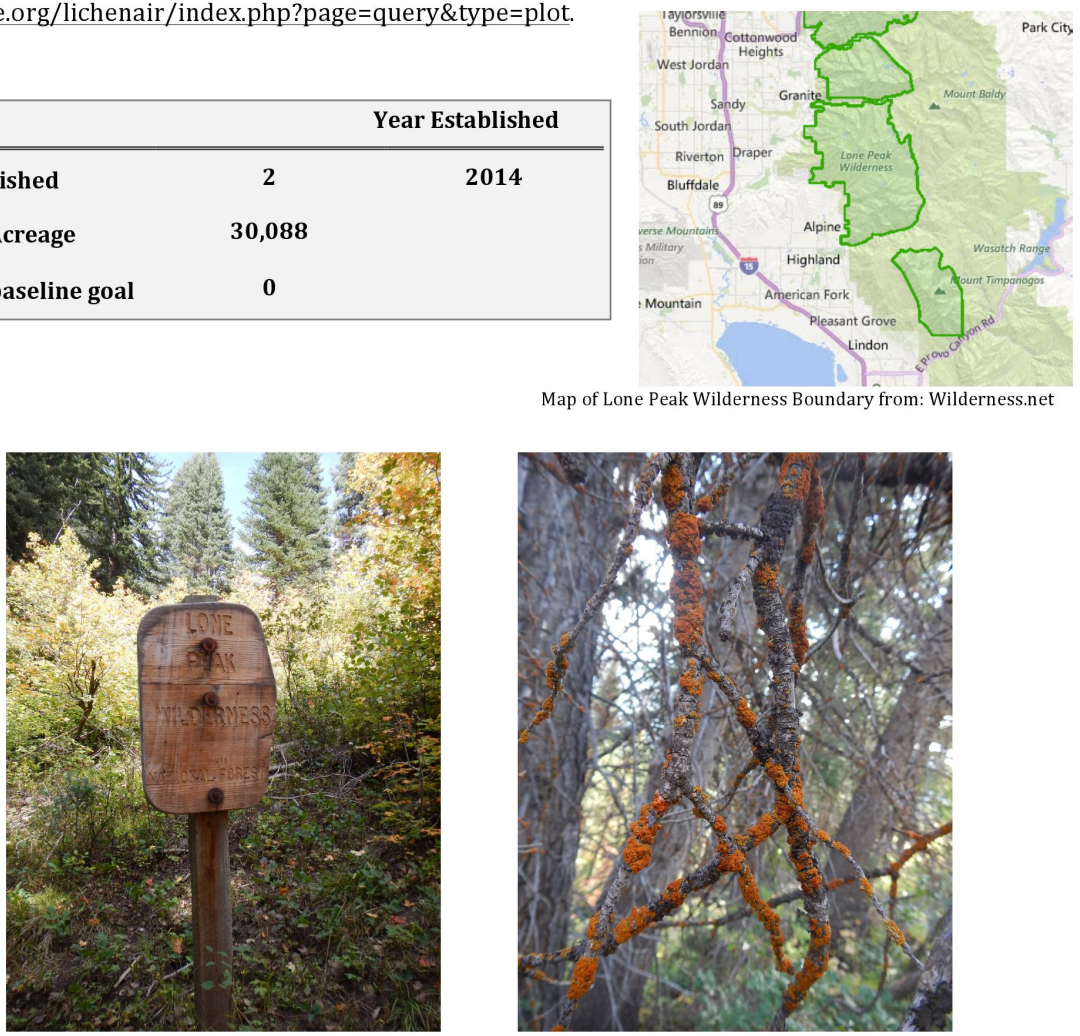

Map of Lone Peak Wilderness Boundary from: Wilderness.net

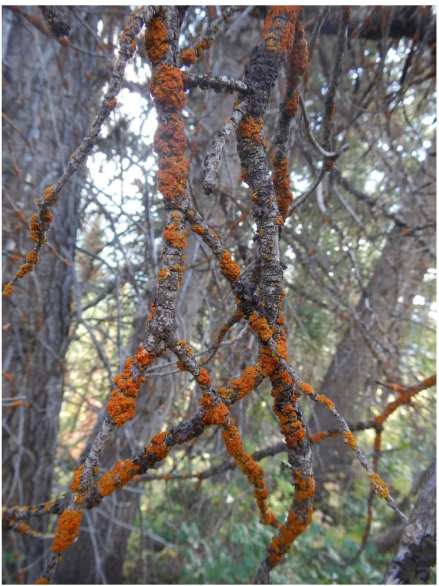




\section{Lone Peak Wilderness}

\section{Lichen Tissue Elemental Concentrations}

The goal of baseline lichen elemental tissue monitoring is to assess current pollutant concentrations and track how they may change, or not change, over time. Pollutant concentrations in epiphytic lichens are correlated with the amounts of pollutants deposited from the atmosphere to vegetation and soils. This table provides baseline elemental values of lichen tissue concentrations for common, abundant epiphytic lichen species found in the Wilderness, shown below as concentration (ppm or \% per dry weight of lichen tissue) of nitrogen, sulfur, arsenic, cadmium, chromium, copper, nickel, lead and zinc, summarized by species. All values were related to mean regional threshold values determined for lichen tissues in the PNW Region; those exceeding threshold values for clean sites are highlighted in bold typeface. Further discussion of lichen $\mathrm{N}$ and S concentrations (\%) are provided in the appendix. Determination of these values to define clean site threshold values specific to the Intermountain Region requires development of a regional lichenbased gradient model.

\begin{tabular}{|c|c|c|c|c|c|c|c|c|c|}
\hline & $\begin{array}{l}\mathrm{N} \\
\%\end{array}$ & $\begin{array}{l}\mathbf{S} \\
\%\end{array}$ & $\begin{array}{l}\text { As } \\
\text { ppm }\end{array}$ & $\begin{array}{l}\mathrm{Cd} \\
\mathrm{ppm}\end{array}$ & $\begin{array}{c}\mathrm{Cr} \\
\mathrm{ppm}\end{array}$ & $\begin{array}{c}\mathrm{Cu} \\
\mathrm{ppm}\end{array}$ & $\begin{array}{c}\mathrm{Ni} \\
\mathrm{ppm}\end{array}$ & $\begin{array}{c}\mathrm{Pb} \\
\mathrm{ppm}\end{array}$ & $\begin{array}{c}\mathrm{Zn} \\
\mathrm{ppm}\end{array}$ \\
\hline \multicolumn{10}{|c|}{ Melanelia exasperatula } \\
\hline \multicolumn{10}{|l|}{$n=1$} \\
\hline mean & 1.9 & 0.2 & 0.8 & 0.2 & 1.7 & 9.3 & 0.8 & 7.0 & 24.1 \\
\hline \multicolumn{10}{|c|}{ Melanelia subolivacea } \\
\hline \multicolumn{10}{|l|}{$n=1$} \\
\hline mean & 2.0 & 0.2 & 0.9 & 0.1 & 1.9 & 7.2 & 1.0 & 5.3 & 21.0 \\
\hline \multicolumn{10}{|c|}{ Physcia adscendends } \\
\hline \multicolumn{10}{|l|}{$n=1$} \\
\hline mean & 1.4 & 0.2 & 1.1 & 0.2 & 2.6 & 9.3 & 1.1 & 6.6 & 27.3 \\
\hline \multicolumn{10}{|c|}{ Xanthomendoza montana } \\
\hline \multicolumn{10}{|l|}{$n=2$} \\
\hline mean & 2.1 & 0.2 & 1.0 & 0.2 & 1.6 & 6.7 & 0.8 & 4.4 & 50.4 \\
\hline $\min$ & 2.0 & 0.2 & 1.0 & 0.2 & 1.6 & 6.0 & 0.7 & 3.9 & 47.5 \\
\hline $\max$ & 2.1 & 0.2 & 1.0 & 0.2 & 1.7 & 7.5 & 0.8 & 4.9 & 53.2 \\
\hline
\end{tabular}




\section{Lone Peak Wilderness}

\section{Community Composition \& Species Sensitivities}

Composition of the epiphytic macrolichen community (non-crustose species on woody substrates) within a plot determines that plot's position along larger regional pollution and climate gradients. The table below summarizes lichen species observed in all plots established in the baseline year, including crustose and ground dwelling species voluntarily collected by surveyors, as well as epiphytic species used in air quality tissue analyses. In lieu of a regional lichen-based gradient model, lichen sensitivity ratings were categorized according to the sensitivity ratings for $\mathrm{N}$ and $\mathrm{S}$ pollutants derived from species distributions in the western United States (Geiser \& Root, in prep). Pollution sensitivity ratings: $\mathbf{M S}=$ most sensitive, $\mathbf{S}$ = sensitive, $\mathbf{I}=$ intermediate, $\mathbf{T}=$ tolerant, $\mathbf{U}=$ unknown. For plot specific species lists for this Wilderness area go to: $\mathrm{http}: / /$ gis.nacse.org/lichenair/index.php?page=query\&type=community.

\begin{tabular}{lcc} 
Species Name & N-Sensitivity & S-Sensitivity \\
\hline Melanelia exasperatula & $\mathrm{S}$ & $\mathrm{S}$ \\
Melanelia subolivacea & $\mathrm{U}$ & $\mathrm{S}$ \\
Melanohalea elegantula & $\mathrm{S}$ & $\mathrm{S}$ \\
Peltigera rufescens & $\mathrm{U}$ & $\mathrm{U}$ \\
Phaeophyscia ciliata & $\mathrm{I}$ & $\mathrm{I}$ \\
Phaeophyscia hispidula & $\mathrm{I}$ & $\mathrm{S}$ \\
Physcia adscendens & $\mathrm{T}$ & $\mathrm{T}$ \\
Physcia aipolia & $\mathrm{T}$ & $\mathrm{I}$ \\
Physcia dubia & $\mathrm{I}$ & $\mathrm{S}$ \\
Physcia stellaris & $\mathrm{I}$ & $\mathrm{T}$ \\
Physciella chloantha & $\mathrm{I}$ & $\mathrm{S}$ \\
Physciella melanchra & $\mathrm{T}$ & $\mathrm{S}$ \\
Ramalina sinensis & $\mathrm{I}$ & $\mathrm{S}$ \\
Usnea lapponica & $\mathrm{S}$ & $\mathrm{S}$ \\
Xanthomendoza fulva & $\mathrm{U}$ & $\mathrm{U}$ \\
Xanthomendoza montana & $\mathrm{U}$ & $\mathrm{U}$ \\
\hline
\end{tabular}

Total species richness

16

Elevated nitrogen and sulfur deposition has distinct effects on epiphytic lichen community composition. Clean air plots with low nitrogen and/or sulfur deposition have a higher frequency of sensitive species than tolerant species. The proportions of species indicative of nitrogen and sulfur deposition for this Wilderness are listed in the table below. The high frequency of $\mathrm{N}$-intermediate species (37\%) suggests elevated $\mathrm{N}$ deposition is occurring in this Wilderness area. Yet, the high frequency of S-sensitive species (56\%) detected suggests that sulfur deposition is minimal.

\begin{tabular}{lcc} 
& $\begin{array}{c}\text { Frequency (\%) } \\
\text { N-Sensitive }\end{array}$ & $\begin{array}{c}\text { Frequency (\%) } \\
\text { S-Sensitive }\end{array}$ \\
\hline Most Sensitive & 0 & 0 \\
Sensitive & 19 & $\mathbf{5 6}$ \\
Intermediate & $\mathbf{3 7}$ & 12.5 \\
Tolerant & 19 & 12.5 \\
Unknown & 25 & 19 \\
\hline
\end{tabular}




\section{Lone Peak Wilderness}

\section{Baseline Monitoring Summary}

The baseline information provided here suggests an intact lichen flora, typical of other lichen floras of the Intermountain Region and the greater central valley of California. The high frequency of $\mathrm{N}$-intermediate species $(37 \%)$ detected suggests early signs of elevated $\mathrm{N}$ deposition in this Wilderness. Yet, sulfur deposition appears minimal in this Wilderness, as a high frequency (56\%) of S-sensitive species was detected. Metal accumulation values were well below PNW threshold values indicated for lichen tissues. Regionally, lichen tissue concentrations of N (\%) were moderately high when compared across the seven Wilderness areas included in the baseline 2014 surveys, suggesting that $\mathrm{N}$ deposition in this Wilderness is higher than $\mathrm{N}$-deposition occurring in other areas of the survey area. These baseline-monitoring plots are to be revisited every 10 years to assess potential changes in lichen community composition and elemental tissue accumulation. Further, the development of a regional lichen gradient model will better our understanding of lichen community response and elemental tissue accumulation in the larger Intermountain Region.

\section{Additional Information}

Interested in participating in an Air
Quality survey?
Co N T ACT S
Air Resource Management
National Program Leader:
Linda Geiser
(202) 756- 0068
Igeiser@fs.fed.us
Region 4 Wilderness/Wild \&
Scenic Rivers Program
Manager:
Sharon Seim
(801) 625 - 5250
sharongseim@fs.fed.us
Reports \& Photos:
Portland State University
Hannah Prather
(971) 340-9748
pratherh@pdx.edu

\section{References and Reading}

Fenn, M.E. L. Geiser, R.Bachman, T.J. Blubaugh, and A. Bytnerowicz. 2007. Atmospheric deposition inputs and effects on lichen chemistry and indicator species in the Columbia River Gorge, USA. Environmental Pollution 146, 77-91.

Geiser, L. 2004. Manual for Monitoring Air Quality Using Lichens on National Forests of the Pacific Northwest. USDA-Forest Service Pacific Northwest Region Technical Paper, R6-NR-AQTP-1-04.126 pp

Geiser, L.H, S.E. Jovan, D.G Glavich, M.K Porter. 2010. Lichen-based critical loads for atmospheric nitrogen in western Oregon and Washington forests, USA. Environmental Pollution 158, 2412-2421

Geiser, L.H. and P.N. Neitlich. 2007. Air pollution and climate gradients in western Oregon and Washington indicated by epiphytic macrolichens. Environmental Pollution 145, 203-218.

Jovan, S. and B. McCune. 2005. Air-Quality Bioindication in the Greater Central Valley of California, with Epiphytic Macrolichen Communities. Ecological Applications 15, 1712-1726.

Holland, E.A, F.J Dentener, B.H Braswell, J.M Sulzman. 1999. Contemporary and pre-industrial global reactive nitrogen budgets. Biogeochemistry 46, 7-43.

Rogers, P. 2007. Factors Influencing Epiphytic Lichen Communities in Aspen-Associated Forests of the Bear River Range, Idaho and Utah Logan, UT: Utah State University. 166p. Dissertation.

Rogers, P.C., K.D. Moore, and R.J. Ryel. 2009. Aspen succession and nitrogen loading: a case for epiphytic lichens as bioindicators in the Rocky Mountains, USA. Journal of Vegetation Science 20, 498-510.

Root, H.T, L.G. Geiser, M.E. Fen, S. Jovan, M.A. Hutton, S. Ahuja, K. Dillman, D. Schirokauer, S. Berryman, J. A. McMurray. 2013. A simple tool for estimating throughfall nitrogen deposition in forests of western North America using lichens. Journal of Forestry and Ecology. Forest Ecology and Management 306, 1-8.

Root. H.T. L.H. Geiser, S. Jovan, P.N. Neitlich. 2015. Epiphytic macrolichen indication of climate and air quality in interior forested mountains of the Pacific Northwest, USA. Ecological Indicators 53, 95-105.

St. Clair, L.L. 1999. A Color Guidebook to Common Rocky Mountain Lichens. Bean Life Science Museum of BYU Publisher. 242 pp.

National Forest Air Quality and Lichen database and clearinghouse

http://gis.nacse.org/lichenair/index.php. 


\section{Mount Naomi Wilderness}

\section{Wilderness Plot Establishment}

The purpose of air quality biomonitoring in Wilderness is to assess the status and trends of air pollutants that can affect air quality related values such as the diversity, composition, and health of flora and fauna. The target density for air quality biomonitoring plots in Intermountain Region Wilderness Areas is 1 plot per 20,000 acres. Individual plots are to be re-sampled every 10 years. The following table summarizes the biomonitoring plots established in the baseline year. To learn more about the rationale for lichen monitoring, read the Region 4 Introductory Wilderness Air Quality 2014 Lichen Biomonitoring report. To map plot locations and obtain plot specific data go to

http://gis.nacse.org/lichenair/index.php?page=query\&type=plot.

\begin{tabular}{|ccc|}
\hline & & Year Established \\
\hline \hline Plots established & 4 & 2014 \\
Wilderness Acreage & 44,523 & \\
Plots left to meet baseline goal & 0 & \\
\hline
\end{tabular}
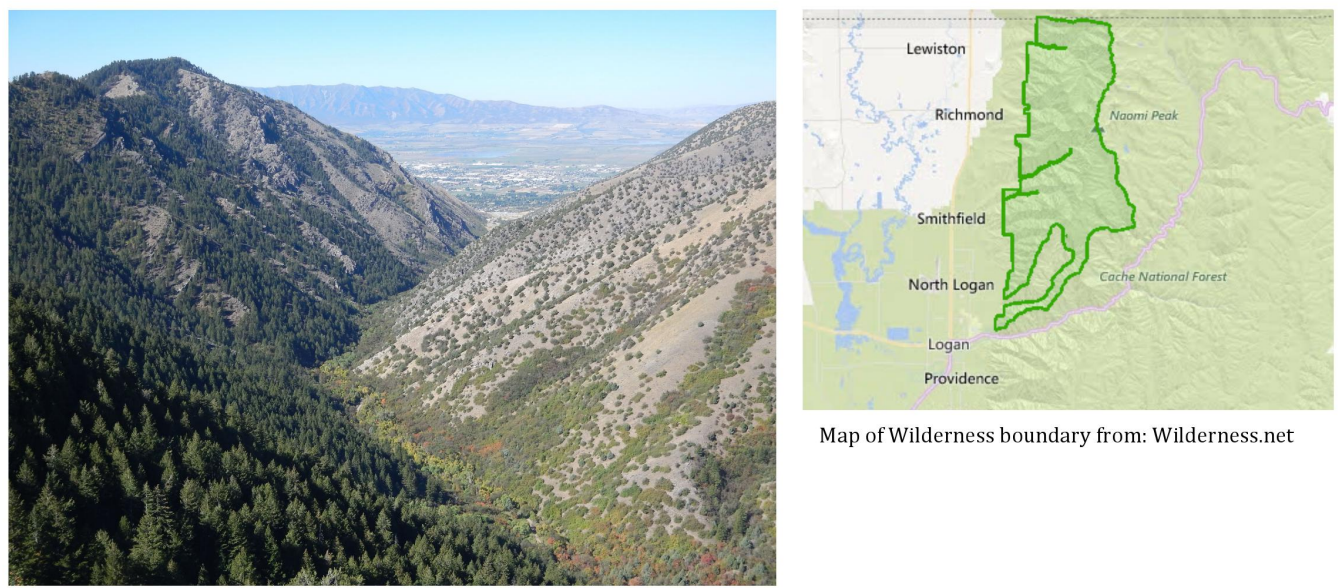

Map of Wilderness boundary from: Wilderness.net 


\section{Mount Naomi Wilderness}

\section{Lichen Tissue Elemental Concentrations}

The goal of baseline lichen elemental tissue monitoring is to assess current pollutant concentrations and track how they may change, or not change, over time. Pollutant concentrations in epiphytic lichens are correlated with the amounts of pollutants deposited from the atmosphere to vegetation and soils. This table provides baseline elemental values of lichen tissue concentrations for common, abundant epiphytic lichen species found in the Wilderness, shown below as concentration (ppm or \% per dry weight of lichen tissue) of nitrogen, sulfur, arsenic, cadmium, chromium, copper, nickel, lead and zinc, summarized by species. All values were related to mean regional threshold values determined for lichen tissues in the PNW Region; those exceeding threshold values for clean sites are highlighted in bold typeface. Further discussion of lichen $\mathrm{N}$ and $\mathrm{S}$ concentrations (\%) are provided in the appendix. Determination of these values to define clean site threshold values specific to the Intermountain Region requires development of a regional lichen-based gradient model.

\begin{tabular}{|c|c|c|c|c|c|c|c|c|c|}
\hline & $\begin{array}{l}\mathrm{N} \\
\% \\
\end{array}$ & $\begin{array}{l}\mathrm{S} \\
\%\end{array}$ & $\begin{array}{c}\text { As } \\
\text { ppm }\end{array}$ & $\begin{array}{c}\text { Cd } \\
\text { ppm }\end{array}$ & $\begin{array}{c}\mathrm{Cr} \\
\mathrm{ppm}\end{array}$ & $\begin{array}{c}\mathrm{Cu} \\
\mathrm{ppm}\end{array}$ & $\begin{array}{c}\mathrm{Ni} \\
\mathrm{ppm}\end{array}$ & $\begin{array}{c}\mathrm{Pb} \\
\mathrm{ppm}\end{array}$ & $\begin{array}{c}\mathrm{Zn} \\
\mathrm{ppm}\end{array}$ \\
\hline \multicolumn{10}{|c|}{ Melanelia exasperatula } \\
\hline \multicolumn{10}{|l|}{$n=2$} \\
\hline mean & 2.1 & 0.2 & 1.1 & 0.1 & 1.6 & 8.3 & 0.9 & 3.8 & 20.9 \\
\hline $\min$ & 2.0 & 0.2 & 1.0 & 0.1 & 1.2 & 7.3 & 0.6 & 2.7 & 16.3 \\
\hline $\max$ & 2.2 & 0.2 & 1.2 & 0.2 & 2.0 & 9.2 & 1.1 & 5.0 & 25.5 \\
\hline \multicolumn{10}{|c|}{ Melanelia subolivacea } \\
\hline \multicolumn{10}{|l|}{$n=1$} \\
\hline mean & 2.8 & 0.2 & 1.2 & 0.1 & 1.3 & 6.9 & 0.6 & 2.1 & 18.8 \\
\hline \multicolumn{10}{|c|}{ Xanthomendoza montana } \\
\hline \multicolumn{10}{|l|}{$n=4$} \\
\hline mean & 2.8 & 0.3 & 1.0 & 0.2 & 1.5 & 6.7 & 0.7 & 2.7 & 27.4 \\
\hline sd & 0.2 & 0.0 & 0.2 & 0.0 & 0.3 & 1.2 & 0.2 & 1.2 & 4.3 \\
\hline $\min$ & 2.5 & 0.2 & 0.7 & 0.1 & 1.1 & 5.5 & 0.6 & 1.6 & 22.3 \\
\hline $\max$ & 3.0 & 0.3 & 1.2 & 0.2 & 1.8 & 8.3 & 0.9 & 3.9 & 32.2 \\
\hline
\end{tabular}




\section{Mount Naomi Wilderness}

\section{Community Composition \& Species Sensitivities}

Composition of the epiphytic macrolichen community (non-crustose species on woody substrates) within a plot determines that plot's position along larger regional pollution and climate gradients. The table below summarizes lichen species observed in all plots established in the baseline year, including crustose and ground dwelling species voluntarily collected by surveyors, as well as epiphytic species used in air quality tissue analyses. In lieu of a regional lichen-based gradient model, lichen sensitivity ratings were categorized according to the sensitivity ratings for $\mathrm{N}$ and $\mathrm{S}$ pollutants derived from species distributions in the western United States (Geiser \& Root, in prep). Pollution sensitivity ratings: $\mathbf{M S}=$ most sensitive, $\mathbf{S}=$ sensitive, $\mathbf{I}=$ intermediate, $\mathbf{T}=$ tolerant, $\mathbf{U}=$ unknown. For plot specific species lists for this Wilderness area go to: http://gis.nacse.org/lichenair/index.php?page=query\&type=community.

\begin{tabular}{lcc} 
Species Name & $\mathrm{N}-$ Sensitivity & S-Sensitivity \\
\hline Leptogium saturninum & $\mathrm{T}$ & $\mathrm{S}$ \\
Megaspora verrucosa & $\mathrm{U}$ & $\mathrm{U}$ \\
Melanelia exasperatula & $\mathrm{S}$ & $\mathrm{S}$ \\
Melanelia subolivacea & $\mathrm{U}$ & $\mathrm{S}$ \\
Melanohalea elegantula & $\mathrm{S}$ & $\mathrm{S}$ \\
Physcia adscendens & $\mathrm{T}$ & $\mathrm{T}$ \\
Physcia dubia & $\mathrm{I}$ & $\mathrm{S}$ \\
Rhizoplaca melanophthalma & $\mathrm{U}$ & $\mathrm{S}$ \\
Usnea lapponica & $\mathrm{S}$ & $\mathrm{U}$ \\
Xanthomendoza fulva & $\mathrm{U}$ & $\mathrm{U}$ \\
Xanthomendoza montana & $\mathrm{U}$ & $\mathrm{U}$ \\
Xanthoparmelia plittii & $\mathrm{U}$ &
\end{tabular}

Elevated nitrogen and sulfur deposition has distinct effects on epiphytic lichen community composition. Clean air plots with low nitrogen and/or sulfur deposition have a higher frequency of sensitive species than tolerant species. The proportions of species indicative of nitrogen and sulfur deposition for this Wilderness are listed in the table below. The low frequency of $\mathrm{N}$-sensitive species (25\%) suggests $\mathrm{N}$ deposition is minimal in this Wilderness. However, at the regional scale, tissue concentrations of $\mathrm{N}(\%)$ collected in this Wilderness were amongst the highest values observed across the seven Wilderness areas surveyed in the baseline year. The high frequency of S-sensitive species (50\%) detected indicates that sulfur deposition is minimal.

\begin{tabular}{lcc} 
& $\begin{array}{c}\text { Frequency (\%) } \\
\text { N-Sensitive }\end{array}$ & $\begin{array}{c}\text { Frequency (\%) } \\
\text { S-Sensitive }\end{array}$ \\
\hline Most Sensitive & 0 & 0 \\
Sensitive & $\mathbf{2 5}$ & $\mathbf{5 0}$ \\
Intermediate & 8 & 0 \\
Tolerant & 17 & 8 \\
Unknown & 50 & 42 \\
\hline
\end{tabular}




\section{Mount Naomi Wilderness}

\section{Baseline Monitoring Summary}

The baseline information provided here suggests an intact lichen flora, typical of other lichen floras of the Intermountain Region and the greater central valley of California. The frequency of $\mathrm{N}$-sensitive species (25\%) detected suggests minimal $\mathrm{N}$ deposition in this Wilderness, however a high frequency of species (50\%) were unassigned to sensitivity groupings. Lichen tissue concentrations of $\mathrm{N}(\%)$ were amongst the highest values measured across the seven Wilderness areas included in the baseline 2014 surveys, suggesting that $\mathrm{N}$ deposition in this Wilderness is higher than $\mathrm{N}$-deposition occurring in other areas of the survey area. Sulfur deposition is minimal in this Wilderness, as a high frequency (50\%) of S-sensitive species was detected. Metal accumulation values were also well below PNW threshold values indicated for lichen tissues. These baseline-monitoring plots are to be revisited every 10 years to assess potential changes in lichen community composition and elemental tissue accumulation. Further, the development of a regional lichen gradient model will better our understanding of lichen community response and elemental tissue accumulation in the larger Intermountain Region.

\section{Additional Information}

\section{References and Reading}

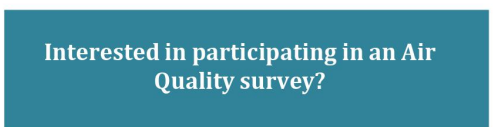

CONTACTS

Air Resource Management National Program Leader: Linda Geiser (202) 756- 0068 lgeiser@fs.fed.us

Region 4 Wilderness/Wild \& Scenic Rivers Program Manager:

Sharon Seim (801) $625-5250$ sharongseim@fs.fed.us

Reports and Photos: Portland State University

Hannah Prather (971) 340-9748 pratherh@pdx.edu
Fenn, M.E. L. Geiser, R.Bachman, T.J. Blubaugh, and A. Bytnerowicz. 2007. Atmospheric deposition inputs and effects on lichen chemistry and indicator species in the Columbia Rive Gorge, USA. Environmental Pollution 146, 77-91.

Geiser, L. 2004. Manual for Monitoring Air Quality Using Lichens on National Forests of the Pacific Northwest. USDA-Forest Service Pacific Northwest Region Technical Paper, R6-NR-AQPacific Northwest

Geiser, L.H, S.E. Jovan, D.G Glavich, M.K Porter. 2010, Lichen-based critical loads for atmospheric nitrogen in western Oregon and Washington forests, USA. Environmental Pollution 158, 2412-2421.

Geiser, L.H. and P.N. Neitlich. 2007. Air pollution and climate gradients in western Oregon and Washington indicated by epiphytic macrolichens. Environmental Pollution 145, 203-218.

Jovan, S. and B. McCune. 2005. Air-Quality Bioindication in the Greater Central Valley of California, with Epiphytic Macrolichen Communities. Ecological Applications 15, 1712-1726.

Holland, E.A, F.J Dentener, B.H Braswell, J.M Sulzman. 1999. Contemporary and pre-industrial global reactive nitrogen budgets. Biogeochemistry 46, 7-43.

Rogers, P. 2007. Factors Influencing Epiphytic Lichen Communities in Aspen-Associated Forests of the Bear River Range, Idaho and Utah Logan, UT: Utah State University. 166p. Dissertation.

Rogers, P.C., K.D. Moore, and R.J. Ryel. 2009. Aspen succession and nitrogen loading: a case for epiphytic lichens as bioindicators in the Rocky Mountains, USA. Journal of Vegetation Science 20 $498-510$

Root, H.T, L.G. Geiser, M.E. Fen, S. Jovan, M.A. Hutton, S. Ahuja, K. Dillman, D. Schirokauer, S. Berryman, J. A. McMurray. 2013. A simple tool for estimating throughfall nitrogen deposition in forests of western North America using lichens. Journal of Forestry and Ecology. Forest Ecology and Management 306, 1-8.

Root. H.T, L.H. Geiser, S. Jovan, P.N. Neitlich. 2015, Epiphytic macrolichen indication of climate and air quality in interior forested mountains of the Pacific Northwest, USA. Ecological Indicators 53, 95-105.

St. Clair, L.L. 1999. A Color Guidebook to Common Rocky Mountain Lichens. Bean Life Science Museum of BYU Publisher. 242 pp

National Forest Air Quality and Lichen database and clearinghouse

http://gis.nacse.org/lichenair/index.php. 


\section{Wellsville Mountains Wilderness}

\section{Wilderness Plot Establishment}

The purpose of air quality biomonitoring in Wilderness is to assess the status and trends of air pollutants that can affect air quality related values such as the diversity, composition, and health of flora and fauna. The target density for air quality biomonitoring plots in Intermountain Region Wilderness Areas is 1 plot per 20,000 acres. Individual plots are to be re-sampled every 10 years. The following table summarizes the biomonitoring plots established in the baseline year. To learn more about the rationale for lichen monitoring, read the Region 4 Introductory Wilderness Air Quality 2014 Lichen Biomonitoring report. To map plot locations and obtain plot specific data go to

http://gis.nacse.org/lichenair/index.php?page=query\&type=plot.

\begin{tabular}{|ccc|}
\hline & & Year Established \\
\hline \hline Plots established & 1 & 2014 \\
Wilderness Acreage & 22,781 & \\
Plots left to meet baseline goal & 1 & \\
\hline
\end{tabular}

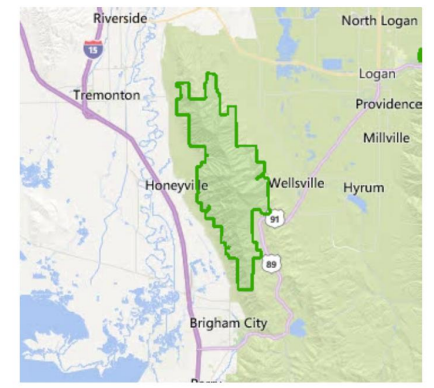

Map of Wilderness boundary from: Wilderness.net
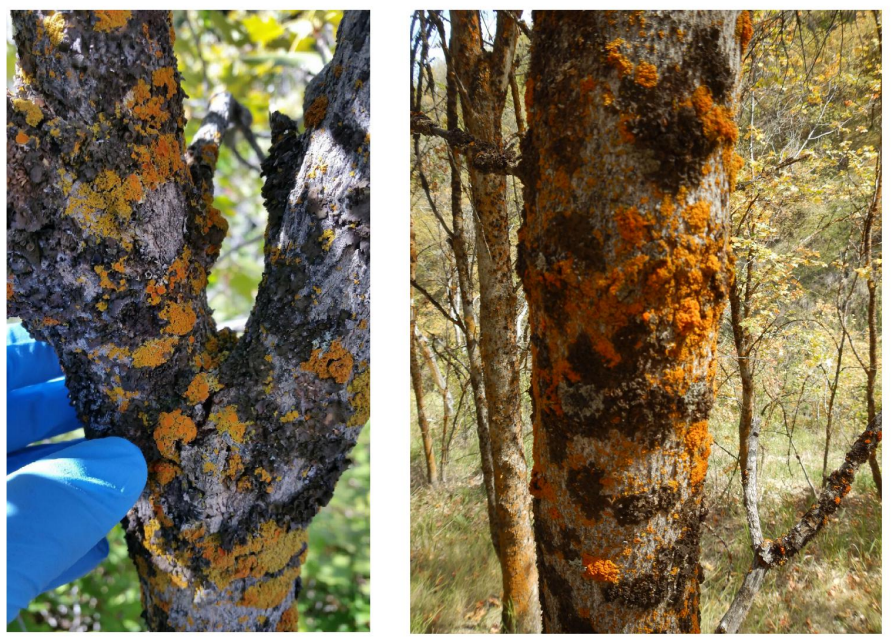


\section{Wellsville Mountains Wilderness}

\section{Lichen Tissue Elemental Concentrations}

The goal of baseline lichen elemental tissue monitoring is to assess current pollutant concentrations and track how they may change, or not change, over time. Pollutant concentrations in epiphytic lichens are correlated with the amounts of pollutants deposited from the atmosphere to vegetation and soils. This table provides baseline elemental values of lichen tissue concentrations for common, abundant epiphytic lichen species found in the Wilderness, shown below as concentration (ppm or \% per dry weight of lichen tissue) of nitrogen, sulfur, arsenic, cadmium, chromium, copper, nickel, lead and zinc, summarized by species. All values were related to mean regional threshold values determined for lichen tissues in the PNW Region; those exceeding threshold values for clean sites are highlighted in bold typeface. Further discussion of lichen $\mathrm{N}$ and $\mathrm{S}$ concentrations (\%) are provided in the appendix. Determination of these values to define clean site threshold values specific to the Intermountain Region requires development of a regional lichen-based gradient model.

\begin{tabular}{|c|c|c|c|c|c|c|c|c|c|}
\hline & $\begin{array}{l}\mathrm{N} \\
\%\end{array}$ & $\begin{array}{l}\mathbf{S} \\
\% \\
\end{array}$ & $\begin{array}{c}\text { As } \\
\text { ppm }\end{array}$ & $\begin{array}{c}\mathrm{Cd} \\
\mathrm{ppm}\end{array}$ & $\begin{array}{c}\mathrm{Cr} \\
\mathrm{ppm}\end{array}$ & $\begin{array}{c}\mathrm{Cu} \\
\mathrm{ppm}\end{array}$ & $\begin{array}{c}\mathrm{Ni} \\
\mathrm{ppm}\end{array}$ & $\begin{array}{c}\mathrm{Pb} \\
\mathrm{ppm}\end{array}$ & $\begin{array}{c}\mathrm{Zn} \\
\mathrm{ppm}\end{array}$ \\
\hline \multicolumn{10}{|c|}{ Melanelia subolivacea } \\
\hline \multicolumn{10}{|l|}{$n=1$} \\
\hline mean & 2.1 & 0.2 & 0.7 & 0.2 & 1.2 & 8.4 & 0.8 & 5.7 & 14.0 \\
\hline \multicolumn{10}{|c|}{ Physcia aipolia } \\
\hline \multicolumn{10}{|l|}{$n=1$} \\
\hline mean & 2.1 & 0.2 & 0.6 & 0.1 & 1.3 & 5.4 & 0.6 & 1.5 & 10.1 \\
\hline \multicolumn{10}{|c|}{ Xanthomendoza montana } \\
\hline \multicolumn{10}{|l|}{$n=1$} \\
\hline mean & 2.2 & 0.2 & 0.6 & 0.2 & 1.4 & 5.1 & 0.7 & 1.7 & 18.5 \\
\hline
\end{tabular}




\section{Wellsville Mountains Wilderness}

\section{Community Composition \& Species Sensitivities}

Composition of the epiphytic macrolichen community (non-crustose species on woody substrates) within a plot determines that plot's position along larger regional pollution and climate gradients. The table below summarizes lichen species observed in all plots established in the baseline year, including crustose and ground dwelling species voluntarily collected by surveyors, as well as epiphytic species used in air quality tissue analyses. In lieu of a regional lichen-based gradient model, lichen sensitivity ratings were categorized according to the sensitivity ratings for $\mathrm{N}$ and $\mathrm{S}$ pollutants derived from species distributions in the western United States (Geiser \& Root, in prep). Pollution sensitivity ratings: $\mathbf{M S}=$ most sensitive, $\mathbf{S}=$ sensitive, $\mathbf{I}$ = intermediate, $\mathbf{T}=$ tolerant, $\mathbf{U}=$ unknown. For plot specific species lists for this Wilderness area go to: http://gis.nacse.org/lichenair/index.php?page=query\&type=community.

\begin{tabular}{lcc} 
Species Name & N-Sensitivity & S-Sensitivity \\
\hline Melanelia subolivacea & $\mathrm{U}$ & $\mathrm{S}$ \\
Melanohalea elegantula & $\mathrm{S}$ & $\mathrm{S}$ \\
Phaeophyscia ciliata & $\mathrm{I}$ & $\mathrm{I}$ \\
Phaeophyscia orbicularis & $\mathrm{T}$ & $\mathrm{I}$ \\
Physcia adscendens & $\mathrm{T}$ & $\mathrm{T}$ \\
Physcia aipolia & $\mathrm{T}$ & $\mathrm{I}$ \\
Xanthomendoza fulva & $\mathrm{U}$ & $\mathrm{U}$ \\
Xanthomendoza montana & $\mathrm{U}$ & $\mathrm{U}$ \\
\hline Total species richness & &
\end{tabular}

Elevated nitrogen and sulfur deposition has distinct effects on epiphytic lichen community composition. Clean air plots with low nitrogen and/or sulfur deposition have a higher frequency of sensitive species than tolerant species. The proportions of species indicative of nitrogen and sulfur deposition for this Wilderness are listed in the table below. The high frequency of $\mathrm{N}$-tolerant species (37.5\%) suggests elevated $\mathrm{N}$ deposition is occurring in this Wilderness. Additionally, the high frequency of S-intermediate species $(37.5 \%)$ detected indicates that sulfur deposition may also be moderately high in this Wilderness area.

\begin{tabular}{lcc} 
& $\begin{array}{c}\text { Frequency (\%) } \\
\text { N-Sensitive }\end{array}$ & $\begin{array}{c}\text { Frequency (\%) } \\
\text { S-Sensitive }\end{array}$ \\
\hline Most Sensitive & 0 & 0 \\
Sensitive & 12.5 & 25 \\
Intermediate & 12.5 & $\mathbf{3 7 . 5}$ \\
Tolerant & 37.5 & 12.5 \\
Unknown & 37.5 & 25 \\
\hline
\end{tabular}




\section{Wellsville Mountains Wilderness}

\section{Baseline Monitoring Summary}

The baseline information provided here suggests an intact lichen flora, typical of other lichen floras of the Intermountain Region and the greater central valley of California. The frequency of $\mathrm{N}$-tolerant species $(37.5 \%)$ detected suggests $\mathrm{N}$ deposition is elevated in this Wilderness, however an equivalent frequency of species $(37.5 \%)$ were also unassigned to sensitivity groupings. Regionally, lichen tissue concentrations of $\mathrm{N}$ (\%) were amongst the highest values measured across the seven Wilderness areas included in the baseline 2014 surveys, suggesting that $\mathrm{N}$-deposition in this Wilderness is higher than $\mathrm{N}$-deposition occurring in other areas of the survey area. Sulfur deposition appears moderately high as indicated by lichen community response. Yet, metal accumulation values were well below PNW threshold values indicated for lichen tissues. These baseline-monitoring plots are to be revisited every 10 years to assess potential changes in lichen community composition and elemental tissue accumulation. Further, the development of a regional lichen gradient model will better our understanding of lichen community response and elemental tissue accumulation in the larger Intermountain Region.

\section{Additional Information}

\section{References and Reading}

\section{Interested in participating in an Air} Quality survey?

CONTACTS

Air Resource Management National Program Leader:

Linda Geiser

(202) 756- 0068

lgeiser@fs.fed.us

Region 4 Wilderness/Wild \& Scenic Rivers Program

Manager:

Sharon Seim

(801) 625 - 5250

sharongseim@fs.fed.us

Reports \& Photos:

Portland State University

Hannah Prather

(971) 340-9748

pratherh@pdx.edu
Fenn, M.E. L. Geiser, R.Bachman, T.J. Blubaugh, and A. Bytnerowicz. 2007. Atmospheric deposition inputs and effects on lichen chemistry and indicator species in the Columbia River Gorge, USA. Environmental Pollution 146, 77-91.

Geiser, L. 2004. Manual for Monitoring Air Quality Using Lichens on National Forests of the Pacific Northwest. USDA-Forest Service Pacific Northwest Region Technical Paper, R6-NR-AQTP-1-04. $126 \mathrm{pp}$

Geiser, L.H, S.E. Jovan, D.G Glavich, M.K Porter. 2010. Lichen-based critical loads for atmospheric nitrogen in western Oregon and Washington forests, USA. Environmental Pollution 158, 2412-2421

Geiser, L.H. and P.N. Neitlich. 2007. Air pollution and climate gradients in western Oregon and Washington indicated by epiphytic macrolichens. Environmental Pollution 145, 203-218.

Jovan, S. and B. McCune. 2005. Air-Quality Bioindication in the Greater Central Valley of California, with Epiphytic Macrolichen Communities. Ecological Applications 15, 1712-1726.

Holland, E.A, F.J Dentener, B.H Braswell, J.M Sulzman. 1999. Contemporary and pre-industrial global reactive nitrogen budgets. Biogeochemistry 46, 7-43.

Rogers, P. 2007. Factors Influencing Epiphytic Lichen Communities in Aspen-Associated Forests of the Bear River Range, Idaho and Utah Logan, UT: Utah State University. 166p. Dissertation.

Rogers, P.C., K.D. Moore, and R.J. Ryel. 2009. Aspen succession and nitrogen loading: a case for epiphytic lichens as bioindicators in the Rocky Mountains, USA. Journal of Vegetation Science 20, 498-510.

Root, H.T, L.G. Geiser, M.E. Fen, S. Jovan, M.A. Hutton, S. Ahuja, K. Dillman, D. Schirokauer, S. Berryman, J. A. McMurray. 2013. A simple tool for estimating throughfall nitrogen deposition in forests of western North America using lichens. Journal of Forestry and Ecology. Forest Ecology and Management 306, 1-8.

Root. H.T, L.H. Geiser, S. Jovan, P.N. Neitlich. 2015. Epiphytic macrolichen indication of climate and air quality in interior forested mountains of the Pacific Northwest, USA. Ecological Indicators 53, 95-105.

St. Clair, L.L. 1999. A Color Guidebook to Common Rocky Mountain Lichens. Bean Life Scienc Museum of BYU Publisher. $242 \mathrm{pp}$

National Forest Air Quality and Lichen database and clearinghous http://gis.nacse.org/lichenair/index.php. 


\section{Appendix - Region 4 Wilderness}

\section{$\mathrm{N}$ and $\mathrm{S}$ concentration (\%) in Lichen Tissues}

Nitrogen concentrations in epiphytic lichens are a well-known approach to passively monitor $\mathrm{N}$ deposition in forested landscapes (see Root et al. 2013) and prior work has shown that lichen $\mathrm{N}$ concentrations are strongly correlated with lichen community composition shifts associated with $\mathrm{N}$ deposition, therefore linking N deposition with biological effects (Geiser and Neitlich 2007, Geiser et al. 2010, Root et al. 2013). Lichen tissue $\mathrm{N}$ concentrations have been formally calibrated against $\mathrm{N}$ deposition across a few western states (AK, CA, OR, WA and WY)(Root et al. 2013), yet no formal calibration has currently been performed for lichen species in the Intermountain Region.

In 2014, baseline lichen and air quality monitoring plots were installed across seven wilderness areas in the Intermountain Region (Ashdown Gorge Wilderness, Box-Death Hollow Wilderness, Cottonwood Forest Wilderness, Dark Canyon Wilderness, Lone Peak Wilderness, Mount Naomi Wilderness, \& Wellsville Mountains Wilderness) within three National Forest areas (Dixie National Forest, Manti-La Sal National Forest and Unita-Wasatch-Cache National Forest). The most common and abundant epiphytic lichen species were collected at each plot and lichen tissues were sent to the USFS Northern Research Station, Forest Science Analytic Laboratory in Grand Rapids, Minnesota for elemental tissue analyses. Tissues were collected following the methods of Geiser (2004) and total N and S was determined by combustion analysis as percent (\%) dry weight using LECOFP528.

We explored the relationship between lichen $\mathrm{N}$ concentration in all lichen species ( $n=7$ species, see species table below) collected at all baseline survey plots ( $n=16$ plots) and NAPD measured wet deposition of total $\mathrm{N}$ (ammonium $\left(\mathrm{NH}_{4}+\right.$ ) and nitrate $\left.\left(\mathrm{NO}_{3}-\right)\right)$ and found a weak correlation $\left(R^{2}=0.20\right)$. We further grouped species to genus level and investigated how $\mathrm{N}$ concentration in different lichen genera from the Intermountain Region related to NADP total N wet deposition. Despite the small number of collections, a strong correlation was observed between Melanelia sp. lichens and NADP total $\mathrm{N}$ wet deposition $\left(R^{2}=0.69\right)$ (Figure $\left.1 \mathrm{~A}\right)$. We further separated ammonium $\left(\mathrm{NH}_{4}+\right)$ from nitrate $\left(\mathrm{NO}_{3}-\right)$ and found Melanelia $s p$. most strongly correlated with ammonium deposition $\left(R^{2}=0.73\right)$ (Figure 1B) over nitrate deposition $\left(R^{2}=0.53\right)$ (Figure $1 \mathrm{C}$ ).
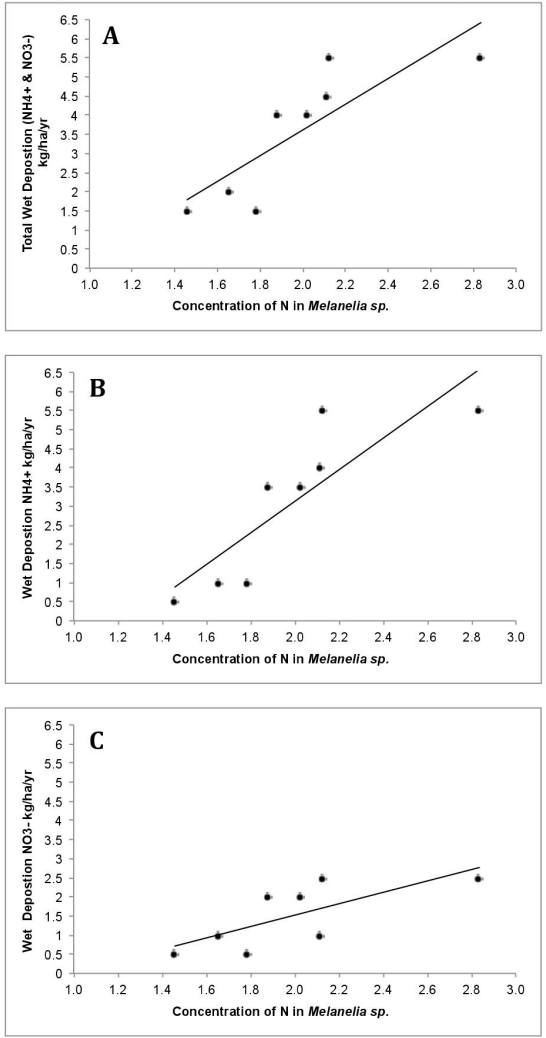

Figure 1 Regressions between NADP measured wet $\mathrm{N}$ deposition and $\mathrm{N}$ concentration in Melanelia species. (A) Total wet $\mathrm{N}$ deposition $\left(\mathrm{NH}_{4}+\& \mathrm{NO}_{3}-\right)$ and $\mathrm{N}$ concentration in Melanelia $\mathrm{sp}$. (B) Wet deposition of ammonim $\left(\mathrm{NH}_{4}\right)$ and $\mathrm{N}$ concentration in (B) Wet deposion in Melanelia sp.; (C) Wet dition concentration in Melanelia sp. from six Wilderness areas surveyed in the 2014 baseline lichen and air quality monitoring study. 


\section{Appendix - Region 4 Wilderness}

\section{$\mathrm{N}$ and $\mathrm{S}$ concentration (\%) in Lichen Tissues}

Melanelia sp. tissue $\mathrm{N}$ concentrations collection in the 2014 baseline study correlated with greater proximity to localized pollution sources, particularly along the population dense Wasatch Front (Figure 2 \& see NADP N deposition maps below). The highest lichen $\mathrm{N}$ concentration was found in the Mount Naomi Wilderness, followed in decreasing order by: Wellsville Mountains Wilderness, Lone Peak Wilderness, Dark Canyon Wilderness, Ashdown Gorge Wilderness, and lastly Box-Death Hollow Wilderness.

\begin{tabular}{lc}
\hline $\begin{array}{l}\text { Lichen species used in } \mathbf{2 0 1 4} \\
\text { elemental tissue analyses }\end{array}$ & $\begin{array}{l}\text { Number of Wilderness } \\
\text { areas collected from }\end{array}$ \\
\hline Melanelia exasperatula & 2 \\
Melanelia subolivacea & 6 \\
Physcia adscendends & 1 \\
Physcia aipolia & 2 \\
Rhizoplaca melanophthalma & 1 \\
Xanthomendoza montana & 5 \\
Xanthoparmelia plittii & 2 \\
\hline
\end{tabular}

Lichen tissue concentrations from the baseline surveys were related to mean elemental tissue threshold values for clean sites from the National Lichens \& Air Quality Database and Clearinghouse, available here: http://gis.nacse.org/lichenair/index.php?page=cleansite.

Interestingly, when lichen $\mathrm{N}$ and $\mathrm{S}$ concentrations were compared to concentrations for tissue threshold values determined for clean sites in Region 6, concentrations appear elevated in every Wilderness area surveyed in the 2014 Region 4 baseline study. Typically in Region 6, lichen N \& S concentrations over $1 \%$ and $0.07 \%$ respectively, are considered elevated. The 2014 baseline survey found that lichen $\mathrm{N}$ and $\mathrm{S}$ tissue concentrations in Region 4 were generally two-fold higher than the clean site threshold concentrations found in in Region 6. More regionwide work is required to better understand the range of tissue concentration values and whether other ecological factors may be driving potentially higher background tissue concentrations of these nutrients in Region 4. Lichen tissue concentrations of S were typically $10 \%$ lower than $\mathrm{N}$ concentrations, a pattern also consistently observed in Region 6 lichen tissue analyses.

The results obtained here reveal epiphytic lichen $\mathrm{N}$ concentrations in Melanelia $s p$. strongly correlate with both ammonium and nitrate deposition in the baseline study area. A formal calibration of lichen species and regional $\mathrm{N}$ and $\mathrm{S}$ deposition will better our understanding of both lichen community response and elemental tissue accumulation across the uniquely varied environmental and depositional gradients that occur in the Intermountain Region.

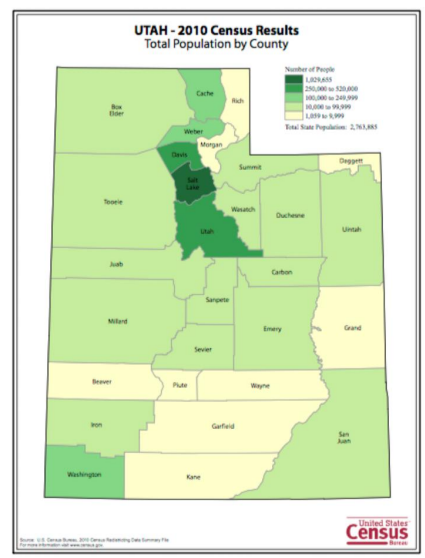

Figure 22010 US Census population density for the state of Utah shows highest population densities along the Wasatch Front area of northern-central Utah. 


\section{Appendix - Region 4 Wilderness}

\section{Nitrogen Deposition - Regional Sources and Patterns}

Nitrogen-containing emissions from agriculture $\left(\mathrm{NH}_{3}\right)$ and emissions from fossil fuel combustion $\left(\mathrm{NO}_{\mathrm{x}}\right)$ contribute the majority of $\mathrm{N}$ containing pollutants in the atmosphere. These pollutants react in the atmosphere and can dissolve in precipitation, falling as rain or snow in the forms of ammonium $\left(\mathrm{NH}_{4}+\right)$ and nitrate $\left(\mathrm{NO}_{3}-\right)$. The National Atmospheric Deposition Program (NADP) measures these forms of $\mathrm{N}^{\left(\mathrm{NH}_{4}+\text { and }\right.}$ $\mathrm{NO}_{3}$ - in wet atmospheric deposition, as it is a relatively simple way to gauge how much $\mathrm{N}$ is being deposited in an ecosystem. Nitrogen is also deposited as a dry form, which may be significant in the Intermountain Region, but it is more difficult to measure directly. To learn more about nitrogen effects on lichens, read the Region 4 Introductory Wilderness Air Quality 2014 Lichen Biomonitoring report.

The NADP Critical Loads of Atmospheric Deposition (CLAD) National Trends Network (NTN) maps below show that hotspots of $\mathrm{N}$ deposition are occurring in northern-central Utah. Additionally, total wet $\mathrm{N}$ deposition has increased in the survey area from 2009 to 2014, the baseline survey year, with more concentrated deposition occurring along the Wasatch Front area of northern-central Utah. Wilderness areas that were nearer these $\mathrm{N}$ hotspots also showed the highest lichen tissue $\mathrm{N}$ concentrations.
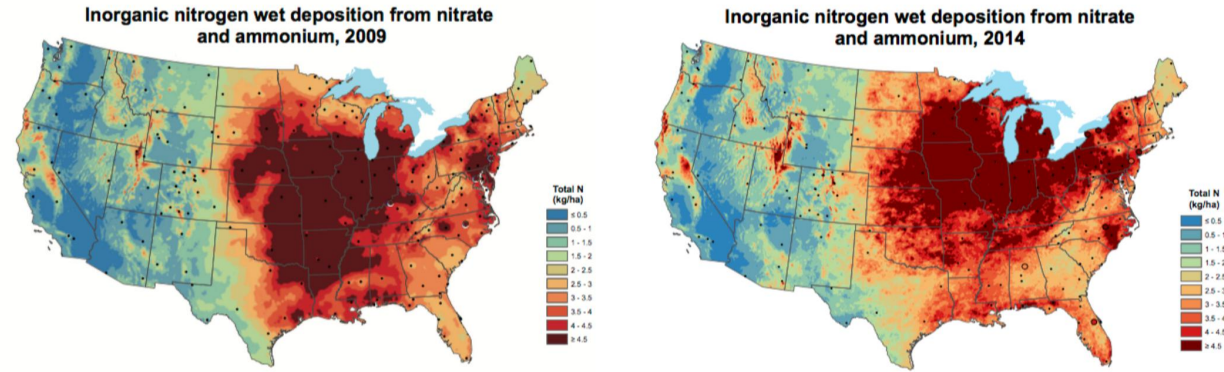

Figure 3 NADP's Critical Loads of Atmospheric Deposition NTN maps showing annual total N wet depositon $\left(\mathrm{NO}_{3}-\right.$ \&

$\left.\mathrm{NH}_{4+}\right)(\mathrm{kg} / \mathrm{ha})$ in 2009 and in 2014, the baseline monitoring year. $\mathrm{N}$ deposition has increased over Region 4 and the study area of Utah over the five-year timespan; hotspots appear along the Wasatch Front area of northern-central Utah. 


\section{Appendix - Region 4 Wilderness Areas}

\section{Nitrogen Deposition - Regional Sources and Patterns}

The NADP Critical Loads of Atmospheric Deposition (CLAD) National Trends Network (NTN) maps below show ammonium is the dominate form of $\mathrm{N}$ being deposited in the study area, although nitrate deposition is also a significant portion of total $\mathrm{N}$ wet deposition along the population dense Wasatch Front.
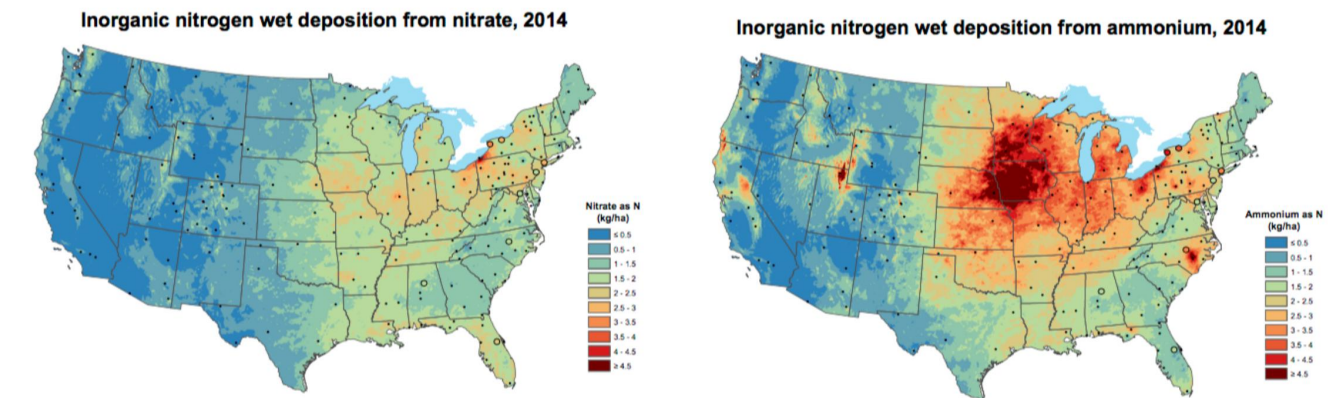

Figure 4 NADP'S Critical Loads of Atmospheric Deposition NTN maps showing annual depositon (kg/ha) of nitrate ( $\left.\mathrm{NO}_{3}-\right)$ and ammonium $\left(\mathrm{NH}_{4}+\right)$ in 2014, the baseline mointoring year. Hotspots of both nitrate and ammonium appear along the population dense Wasatch Front portion of Utah.

\section{Sulfur Deposition - Regional Sources and Patterns}

Wet deposition of total sulfur (S) from NADP shows improvements in deposition from 2009 to the baseline survey year 2014, with more concentrated deposition occurring along the Wasatch Front in the northerncentral portion of Utah. Sulfur deposition has dramatically decreased in the US due to the implementation of the Federal Clean Air Act. Sulfur emission sources are typically coal-fired electric utilities and fuel combustions from industrial, commercial and institutional sources. All Lichens are sensitive to sulfur dioxide, although some are more sensitive than others. The effect on lichen communities is a decrease in diversity, as sensitive species are lost but no new species replace them.
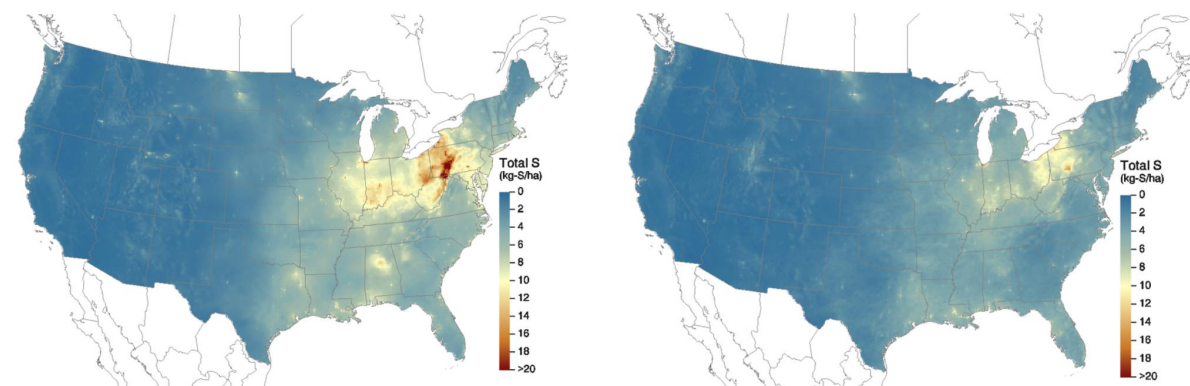

Figure 5 NADP TDEP maps showing total annual wet depositon sulfur depostion (kg-S/ha) in in 2009 and 2014, the baseline survey year. S deposition has improved over Region 4 and the study area of Utah over the five-year timespan; hotspots appear' along the Wasatch Front area of northern-central Utah. 


\section{Appendix - Region 4 Wilderness Areas}

\section{Additional References and Reading}

Geiser, L. H. 2004. Monitoring Air Quality Using Lichens on National Forests of the Pacific Northwest: Methods and Strategy. USDA- Forest Service Pacific Northwest Regional Technical Paper:134.

Geiser, L. H., S. E. Jovan, D. A. Glavich, and M. K. Porter. 2010. Lichen-based critical loads for atmospheric nitrogen deposition in Western Oregon and Washington Forests, USA. Environmental Pollution 158:2412-2421.

Geiser, L. H., and P. N. Neitlich. 2007. Air pollution and climate gradients in western Oregon and Washington indicated by epiphytic macrolichens. Environmental pollution (Barking, Essex : 1987) 145:203-18.

National Atmospheric Deposition Program (NRSP-3). 2015. NADP Program Office, Illinois State Water Survey, University of Illinois, Champaign, IL 61820

National Forest Air Quality and Lichen database and clearinghouse http://gis.nacse.org/lichenair/index.php.

Root, H. T., L. H. Geiser, M. E. Fenn, S. Jovan, M. a. Hutten, S. Ahuja, K. Dillman, D. Schirokauer, S. Berryman, and J. a. Mcmurray. 2013. A simple tool for estimating throughfall nitrogen deposition in forests of western North America using lichens. Forest Ecology and Management 306:1-8. 
Figure F.1 Supplemental summary statistics for 17 elements (Al, B, Ba, Ca, Co, Fe, K, $\mathrm{Mg}, \mathrm{Mn}, \mathrm{Mo}, \mathrm{Na}, \mathrm{P}, \mathrm{S}$ (\%, combustion analyzed), Si, Sr, Ti, V) for lichen tissues collected in seven different wilderness areas during the 2014 baseline Region 4 Wilderness surveys.

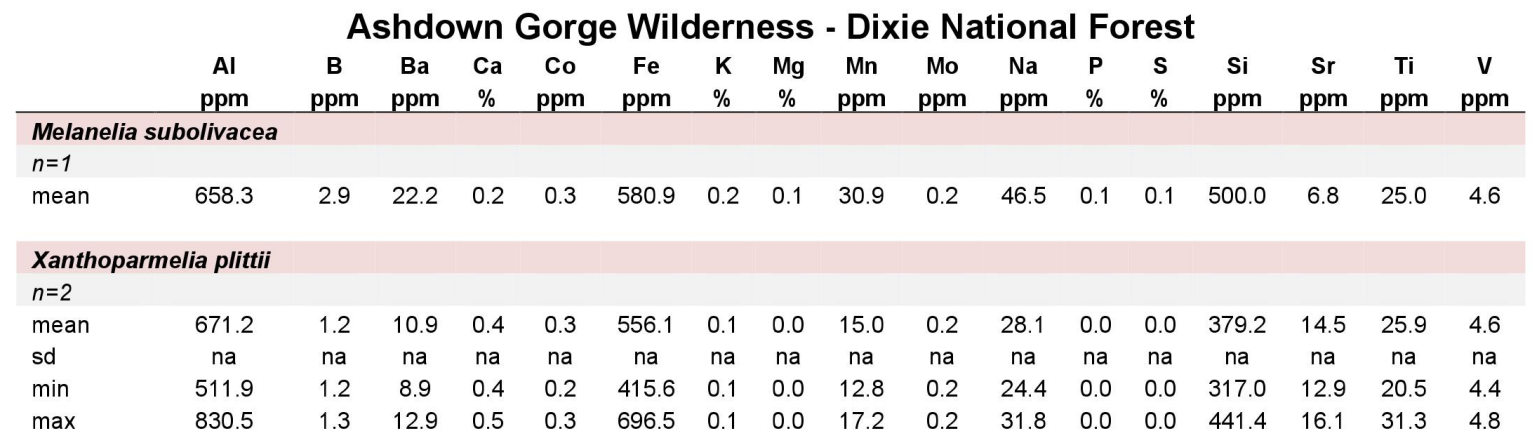

\begin{tabular}{|c|c|c|c|c|c|c|c|c|c|c|c|c|c|c|c|c|c|}
\hline \multicolumn{18}{|c|}{ Box-Death Hollow Wilderness - Dixie National Forest } \\
\hline & $\begin{array}{c}\mathrm{Al} \\
\mathrm{ppm}\end{array}$ & $\begin{array}{c}\text { B } \\
\text { ppm }\end{array}$ & $\begin{array}{c}\mathrm{Ba} \\
\mathrm{ppm}\end{array}$ & $\begin{array}{l}\mathrm{Ca} \\
\%\end{array}$ & $\begin{array}{c}\text { Co } \\
\text { ppm }\end{array}$ & $\begin{array}{c}\text { Fe } \\
\text { ppm }\end{array}$ & $\begin{array}{l}\mathrm{K} \\
\% \\
\end{array}$ & $\begin{array}{c}\mathrm{Mg} \\
\%\end{array}$ & $\begin{array}{l}\text { Mn } \\
\text { ppm }\end{array}$ & $\begin{array}{l}\text { Mo } \\
\text { ppm }\end{array}$ & $\begin{array}{c}\mathrm{Na} \\
\mathrm{ppm}\end{array}$ & $\begin{array}{l}P \\
\%\end{array}$ & $\begin{array}{l}\mathbf{S} \\
\%\end{array}$ & $\begin{array}{c}\mathrm{Si} \\
\mathrm{ppm}\end{array}$ & $\begin{array}{c}\mathrm{Sr} \\
\mathrm{ppm}\end{array}$ & $\begin{array}{c}\mathrm{Ti} \\
\mathrm{ppm}\end{array}$ & $\begin{array}{c}\mathrm{V} \\
\mathrm{ppm}\end{array}$ \\
\hline \multicolumn{18}{|c|}{ Melanelia subolivacea } \\
\hline$n=2$ & & & & & & & & & & & & & & & & & \\
\hline mean & 630.2 & 2.4 & 30.6 & 0.1 & 0.3 & 539.3 & 0.2 & 0.0 & 40.3 & 0.2 & 28.6 & 0.1 & 0.0 & 391.7 & 12.1 & 21.6 & 4.5 \\
\hline sd & na & na & na & na & na & na & na & na & na & na & na & na & na & na & na & na & na \\
\hline $\min$ & 507.5 & 1.8 & 26.9 & 0.1 & 0.2 & 424.2 & 0.2 & 0.0 & 28.4 & 0.2 & 27.3 & 0.1 & 0.0 & 316.0 & 10.9 & 17.8 & 4.4 \\
\hline $\max$ & 752.8 & 3.0 & 34.4 & 0.2 & 0.3 & 654.4 & 0.2 & 0.1 & 52.2 & 0.2 & 29.8 & 0.1 & 0.0 & 467.4 & 13.4 & 25.4 & 4.7 \\
\hline
\end{tabular}

\begin{tabular}{|c|c|c|c|c|c|c|c|c|c|c|c|c|c|c|c|c|c|}
\hline \multirow{2}{*}{\multicolumn{18}{|c|}{$\begin{array}{l}\text { Xanthomendoza montana } \\
n=2\end{array}$}} \\
\hline & & & & & & & & & & & & & & & & & \\
\hline mean & 684.3 & 3.0 & 19.8 & 0.1 & 0.4 & 557.6 & 0.4 & 0.1 & 91.0 & 0.2 & 36.4 & 0.1 & 0.1 & 500.8 & 6.2 & 23.4 & 4.6 \\
\hline sd & na & na & na & na & na & na & na & na & na & na & na & na & na & na & na & na & na \\
\hline $\min$ & 361.8 & 2.0 & 10.4 & 0.0 & 0.2 & 301.4 & 0.3 & 0.0 & 62.4 & 0.2 & 32.2 & 0.1 & 0.1 & 351.3 & 3.8 & 12.5 & 4.2 \\
\hline $\max$ & 1006.8 & 4.0 & 29.3 & 0.1 & 0.5 & 813.8 & 0.4 & 0.1 & 119.7 & 0.3 & 40.6 & 0.1 & 0.1 & 650.3 & 8.7 & 34.2 & 5.0 \\
\hline
\end{tabular}

\begin{tabular}{|c|c|c|c|c|c|c|c|c|c|c|c|c|c|c|c|c|c|}
\hline \multirow{2}{*}{\multicolumn{18}{|c|}{$\begin{array}{l}\text { Xanthoparmelia plittii } \\
n=3\end{array}$}} \\
\hline & & & & & & & & & & & & & & & & & \\
\hline $\mathrm{sd}$ & 211.1 & 0.5 & 2.6 & 0.1 & 0.0 & 97.3 & 0.0 & 0.0 & 6.2 & 0.0 & 1.6 & 0.0 & 0.0 & 68.2 & 10.6 & 1.3 & 0.2 \\
\hline $\max$ & 726.2 & 1.9 & 13.8 & 0.5 & 0.2 & 520.1 & 0.1 & 0.0 & 20.7 & 0.2 & 19.0 & 0.1 & 0.0 & 354.3 & 29.8 & 16.9 & 4.6 \\
\hline
\end{tabular}

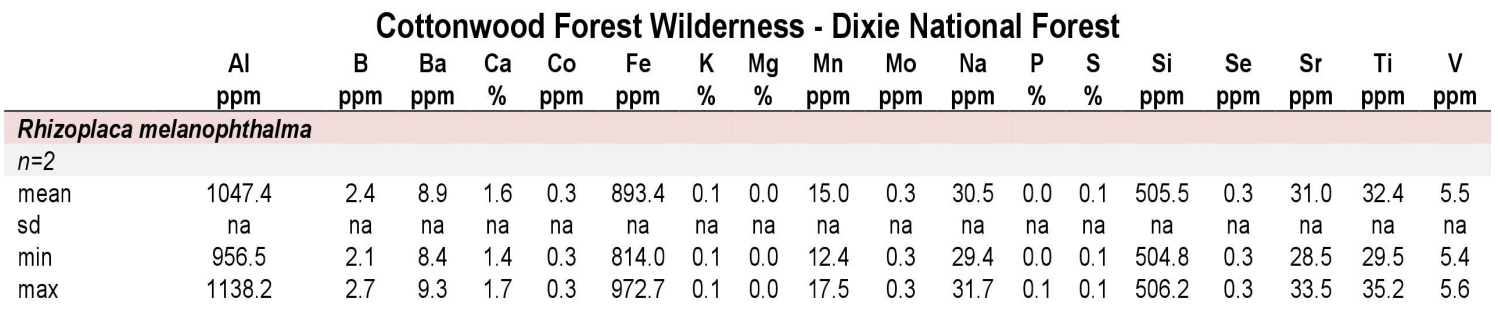


Dark Canyon Wilderness - Manti-LaSal National Forest

\begin{tabular}{|c|c|c|c|c|c|c|c|c|c|c|c|c|c|c|c|c|c|}
\hline & $\begin{array}{c}\text { Al } \\
\mathrm{ppm}\end{array}$ & $\begin{array}{c}\text { B } \\
\text { ppm }\end{array}$ & $\begin{array}{c}\mathrm{Ba} \\
\mathrm{ppm}\end{array}$ & $\begin{array}{l}\mathrm{Ca} \\
\%\end{array}$ & $\begin{array}{c}\text { Co } \\
\text { ppm }\end{array}$ & $\begin{array}{c}\mathrm{Fe} \\
\mathrm{ppm}\end{array}$ & $\begin{array}{l}\mathrm{K} \\
\% \\
\end{array}$ & $\begin{array}{c}\mathrm{Mg} \\
\% \\
\end{array}$ & $\begin{array}{c}\mathrm{Mn} \\
\mathrm{ppm}\end{array}$ & $\begin{array}{c}\text { Mo } \\
\text { ppm }\end{array}$ & $\begin{array}{c}\mathrm{Na} \\
\mathrm{ppm}\end{array}$ & $\begin{array}{l}\mathrm{P} \\
\%\end{array}$ & $\begin{array}{l}\mathbf{S} \\
\%\end{array}$ & $\begin{array}{c}\text { Si } \\
\text { ppm }\end{array}$ & $\begin{array}{c}\mathrm{Sr} \\
\mathrm{ppm}\end{array}$ & $\begin{array}{c}\mathrm{Ti} \\
\mathrm{ppm}\end{array}$ & $\begin{array}{c}\text { V } \\
\text { ppm }\end{array}$ \\
\hline \multicolumn{18}{|c|}{ Melanelia subolivacea } \\
\hline \multicolumn{18}{|l|}{$n=2$} \\
\hline mean & 1260.1 & 2.6 & 15.0 & 0.2 & 0.4 & 864.3 & 0.2 & 0.1 & 29.6 & 0.2 & 29.0 & 0.1 & 0.1 & 637.2 & 6.3 & 24.5 & 5.1 \\
\hline sd & na & na & na & na & na & na & na & na & na & na & na & na & na & na & na & na & na \\
\hline $\min$ & 933.3 & 2.3 & 13.3 & 0.1 & 0.3 & 633.5 & 0.2 & 0.0 & 17.4 & 0.2 & 24.4 & 0.1 & 0.0 & 501.2 & 5.5 & 18.2 & 4.8 \\
\hline $\max$ & 1587.0 & 3.0 & 16.6 & 0.2 & 0.4 & 1095.1 & 0.2 & 0.1 & 41.7 & 0.2 & 33.6 & 0.1 & 0.1 & 773.2 & 7.0 & 30.8 & 5.5 \\
\hline
\end{tabular}

\begin{tabular}{|c|c|c|c|c|c|c|c|c|c|c|c|c|c|c|c|c|c|}
\hline \multicolumn{18}{|c|}{ Physcia aipolia } \\
\hline sd & na & na & na & na & na & na & na & na & na & na & na & na & na & na & na & na & na \\
\hline $\max$ & na & na & na & na & na & na & na & na & na & na & na & na & na & na & na & na & na \\
\hline
\end{tabular}

Xanthomendoza montana

$n=2$

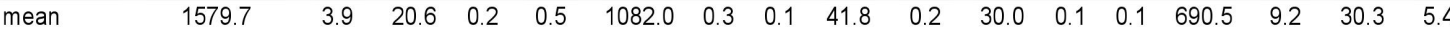

sd na na na na na na na na na na na na na na na na na

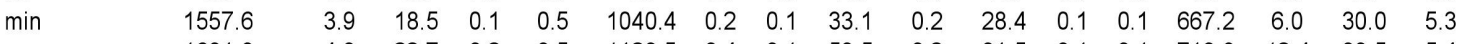

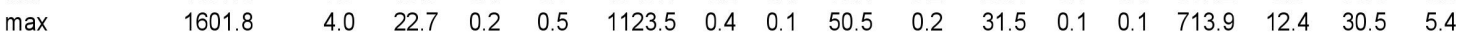

\section{Lone Peak Wilderness - Uinta-Wasatch-Cache National Forest}

\begin{tabular}{|c|c|c|c|c|c|c|c|c|c|c|c|c|c|c|c|c|c|c|}
\hline & $\begin{array}{c}\mathrm{Al} \\
\mathrm{ppm}\end{array}$ & $\begin{array}{c}\text { B } \\
\text { ppm }\end{array}$ & $\begin{array}{c}\mathrm{Ba} \\
\mathrm{ppm}\end{array}$ & $\begin{array}{l}\mathrm{Ca} \\
\%\end{array}$ & $\begin{array}{c}\text { Co } \\
\mathrm{ppm}\end{array}$ & $\begin{array}{c}\mathrm{Fe} \\
\mathrm{ppm}\end{array}$ & $\begin{array}{l}\mathrm{K} \\
\%\end{array}$ & $\begin{array}{c}\mathrm{Mg} \\
\%\end{array}$ & $\begin{array}{c}\mathrm{Mn} \\
\mathrm{ppm}\end{array}$ & $\begin{array}{c}\text { Mo } \\
\mathrm{ppm}\end{array}$ & $\begin{array}{c}\mathrm{Na} \\
\mathrm{ppm}\end{array}$ & $\begin{array}{l}\mathrm{P} \\
\%\end{array}$ & $\begin{array}{l}\mathrm{S} \\
\%\end{array}$ & $\begin{array}{c}\mathrm{Se} \\
\mathrm{ppm}\end{array}$ & $\begin{array}{c}\text { Si } \\
\text { ppm }\end{array}$ & $\begin{array}{c}\mathrm{Sr} \\
\mathrm{ppm}\end{array}$ & $\begin{array}{c}\mathrm{Ti} \\
\mathrm{ppm}\end{array}$ & $\begin{array}{c}\text { V } \\
\text { ppm }\end{array}$ \\
\hline \multicolumn{19}{|c|}{ Melanelia exasperatula } \\
\hline \multicolumn{19}{|l|}{$n=1$} \\
\hline mean & 817.9 & 4.6 & 28.4 & 0.3 & 0.3 & 774.3 & 0.2 & 0.1 & 35.8 & 0.6 & 145.7 & 0.1 & 0.1 & 0.3 & 526.8 & 14.6 & 29.4 & 4.8 \\
\hline \multicolumn{19}{|c|}{ Melanelia subolivacea } \\
\hline \multicolumn{19}{|l|}{$n=1$} \\
\hline mean & 884.1 & 4.0 & 29.3 & 0.3 & 0.3 & 822.2 & 0.2 & 0.1 & 35.7 & 0.4 & 68.6 & 0.1 & 0.1 & 0.2 & 474.5 & 12.0 & 30.3 & 5.0 \\
\hline
\end{tabular}

Physcia adscendends

$n=1$

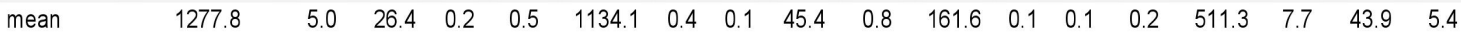

\begin{tabular}{|c|c|c|c|c|c|c|c|c|c|c|c|c|c|c|c|c|c|c|}
\hline \multicolumn{19}{|c|}{ Xanthomendoza montana } \\
\hline \multicolumn{19}{|l|}{$n=2$} \\
\hline mean & 814.4 & 4.5 & 25.2 & 0.1 & 0.3 & 736.5 & 0.4 & 0.1 & 36.8 & 0.4 & 111.0 & 0.1 & 0.1 & na & 512.9 & 5.6 & 27.5 & 4.8 \\
\hline sd & na & na & na & na & na & na & na & na & na & na & na & na & na & na & na & na & na & na \\
\hline $\min$ & 717.8 & 4.0 & 22.1 & 0.1 & 0.3 & 673.9 & 0.3 & 0.1 & 35.7 & 0.3 & 81.5 & 0.1 & 0.1 & na & 487.2 & 5.6 & 24.5 & 4.7 \\
\hline $\max$ & 911.0 & 4.9 & 28.4 & 0.1 & 0.3 & 799.1 & 0.4 & 0.1 & 37.9 & 0.4 & 140.4 & 0.1 & 0.1 & na & 538.7 & 5.7 & 30.6 & 4.9 \\
\hline
\end{tabular}

Mount Naomi Wilderness - Uinta-Wasatch-Cache National Forest

\begin{tabular}{|c|c|c|c|c|c|c|c|c|c|c|c|c|c|c|c|c|c|c|}
\hline & $\begin{array}{c}\text { Al } \\
\text { ppm }\end{array}$ & $\begin{array}{c}\text { B } \\
\text { ppm }\end{array}$ & $\begin{array}{c}\mathrm{Ba} \\
\mathrm{ppm}\end{array}$ & $\begin{array}{l}\mathrm{Ca} \\
\%\end{array}$ & $\begin{array}{c}\text { Co } \\
\mathrm{ppm}\end{array}$ & $\begin{array}{c}\mathrm{Fe} \\
\mathrm{ppm}\end{array}$ & $\begin{array}{l}\mathrm{K} \\
\% \\
\end{array}$ & $\begin{array}{c}\mathrm{Mg} \\
\%\end{array}$ & $\begin{array}{c}\mathrm{Mn} \\
\mathrm{ppm}\end{array}$ & $\begin{array}{c}\text { Mo } \\
\text { ppm }\end{array}$ & $\begin{array}{c}\mathrm{Na} \\
\mathrm{ppm}\end{array}$ & $\begin{array}{l}\mathrm{P} \\
\% \\
\end{array}$ & $\begin{array}{l}\mathrm{S} \\
\%\end{array}$ & $\begin{array}{c}\text { Se } \\
\text { ppm }\end{array}$ & $\begin{array}{c}\text { Si } \\
\text { ppm }\end{array}$ & $\begin{array}{c}\mathrm{Sr} \\
\mathrm{ppm}\end{array}$ & $\begin{array}{c}\mathrm{Ti} \\
\mathrm{ppm}\end{array}$ & $\begin{array}{c}\mathrm{V} \\
\mathrm{ppm}\end{array}$ \\
\hline \multicolumn{19}{|c|}{ Melanelia exasperatula } \\
\hline \multicolumn{19}{|l|}{$n=2$} \\
\hline mean & 1047.3 & 5.0 & 14.9 & 0.3 & 0.3 & 907.7 & 0.3 & 0.1 & 26.1 & 0.5 & 79.1 & 0.1 & 0.1 & na & 544.4 & 10.8 & 38.1 & 5.1 \\
\hline sd & na & na & na & na & na & na & na & na & na & na & na & na & na & na & na & na & na & na \\
\hline $\min$ & 697.5 & 4.2 & 12.7 & 0.2 & 0.3 & 624.2 & 0.3 & 0.1 & 24.1 & 0.4 & 61.0 & 0.1 & 0.1 & na & 538.2 & 9.9 & 24.4 & 4.6 \\
\hline $\max$ & 1397.0 & 5.8 & 17.1 & 0.3 & 0.4 & 1191.3 & 0.3 & 0.1 & 28.1 & 0.6 & 97.3 & 0.1 & 0.1 & na & 550.5 & 11.6 & 51.8 & 5.5 \\
\hline \multicolumn{19}{|c|}{ Melanelia subolivacea } \\
\hline \multicolumn{19}{|l|}{$n=1$} \\
\hline mean & 687.9 & 3.3 & 10.5 & 0.2 & 0.2 & 614.7 & 0.2 & 0.1 & 17.8 & 0.4 & 75.8 & 0.1 & 0.1 & 0.2 & 478.6 & 6.9 & 24.3 & 4.7 \\
\hline \multicolumn{19}{|c|}{ Xanthomendoza montana } \\
\hline \multicolumn{19}{|l|}{$n=4$} \\
\hline mean & 919.2 & 3.5 & 8.7 & 0.1 & 0.3 & 794.6 & 0.3 & 0.1 & 20.0 & 0.4 & 50.3 & 0.1 & 0.1 & na & 580.1 & 3.3 & 32.8 & 4.9 \\
\hline sd & 189.3 & 0.6 & 3.0 & 0.0 & 0.0 & 164.8 & 0.1 & 0.0 & 5.0 & 0.1 & 8.7 & 0.0 & 0.0 & na & 118.6 & 0.3 & 6.5 & 0.2 \\
\hline $\min$ & 697.0 & 2.9 & 5.8 & 0.1 & 0.3 & 610.1 & 0.2 & 0.1 & 14.9 & 0.3 & 40.3 & 0.0 & 0.1 & na & 429.9 & 3.0 & 24.6 & 4.6 \\
\hline $\max$ & 1142.7 & 4.4 & 11.5 & 0.1 & 0.3 & 986.2 & 0.4 & 0.1 & 25.1 & 0.5 & 60.5 & 0.1 & 0.1 & na & 689.2 & 3.8 & 40.3 & 5.2 \\
\hline
\end{tabular}


Wellsville Mountain Wilderness - Uinta-Wasatch-Cache National Forest

\begin{tabular}{|c|c|c|c|c|c|c|c|c|c|c|c|c|c|c|c|c|c|c|}
\hline & $\begin{array}{c}\text { Al } \\
\text { ppm }\end{array}$ & $\begin{array}{c}\text { B } \\
\text { ppm }\end{array}$ & $\begin{array}{c}\mathrm{Ba} \\
\mathrm{ppm}\end{array}$ & $\begin{array}{c}\mathrm{Ca} \\
\%\end{array}$ & $\begin{array}{c}\text { Co } \\
\text { ppm }\end{array}$ & $\begin{array}{c}\mathrm{Fe} \\
\mathrm{ppm}\end{array}$ & $\begin{array}{l}\mathrm{K} \\
\% \\
\end{array}$ & $\begin{array}{c}\mathrm{Mg} \\
\% \\
\end{array}$ & $\begin{array}{c}\mathrm{Mn} \\
\mathrm{ppm}\end{array}$ & $\begin{array}{c}\text { Mo } \\
\mathrm{ppm}\end{array}$ & $\begin{array}{c}\mathrm{Na} \\
\mathrm{ppm}\end{array}$ & $\begin{array}{l}\mathrm{P} \\
\% \\
\end{array}$ & $\begin{array}{l}\mathrm{S} \\
\%\end{array}$ & $\begin{array}{c}\text { Se } \\
\text { ppm }\end{array}$ & $\begin{array}{c}\text { Si } \\
\text { ppm }\end{array}$ & $\begin{array}{c}\mathrm{Sr} \\
\mathrm{ppm}\end{array}$ & $\begin{array}{c}\mathrm{Ti} \\
\text { ppm }\end{array}$ & $\begin{array}{c}\mathrm{V} \\
\text { ppm }\end{array}$ \\
\hline \multicolumn{19}{|c|}{ Melanelia subolivacea } \\
\hline \multicolumn{19}{|l|}{$n=1$} \\
\hline mean & 713.9 & 5.1 & 20.2 & 0.2 & 0.3 & 605.2 & 0.3 & 0.1 & 42.1 & 0.5 & 40.9 & 0.1 & 0.1 & 0.3 & 473.7 & 15.6 & 23.6 & 4.6 \\
\hline \multicolumn{19}{|c|}{ Physcia aipolia } \\
\hline \multicolumn{19}{|l|}{$n=1$} \\
\hline mean & 532.7 & 2.9 & 11.4 & 0.2 & 0.2 & 462.8 & 0.2 & 0.1 & 16.5 & 0.4 & 85.3 & 0.1 & 0.1 & na & 422.6 & 9.5 & 17.9 & 4.4 \\
\hline \multicolumn{19}{|c|}{ Xanthomendoza montana } \\
\hline \multicolumn{19}{|l|}{$n=1$} \\
\hline mean & 606.0 & 3.4 & 9.3 & 0.1 & 0.3 & 555.4 & 0.3 & 0.1 & 27.9 & 0.4 & 41.6 & 0.1 & 0.1 & na & 513.6 & 4.9 & 20.9 & 4.5 \\
\hline
\end{tabular}

